\author{
Universidade de São Paulo \\ Faculdade de Filosofia, Letras e Ciências Humanas \\ Departamento de Letras Modernas
}

Programa de Pós-Graduação em Estudos Linguísticos e Literários em Inglês

Marcos Tadeu Fabris Gonçalves

\title{
Correspondências - arte, técnica e processo histórico
}

São Paulo

2011 


\author{
Universidade de São Paulo \\ Faculdade de Filosofia, Letras e Ciências Humanas \\ Departamento de Letras Modernas \\ Programa de Pós-Graduação em Estudos Linguísticos e Literários em Inglês
}

\title{
Correspondências - arte, técnica e processo histórico
}

Marcos Tadeu Fabris Gonçalves

Tese apresentada ao Programa de Pós-Graduação em Estudos Linguísticos e Literários em Inglês do Departamento de Letras Modernas da Faculdade de Filosofia, Letras e Ciências Humanas da Universidade de São Paulo, para obtenção do título de Doutor em Letras.

Orientadora: Profa. Dra. Maria Elisa Burgos Pereira da Silva Cevasco. 
Autorizo a reprodução e divulgação total ou parcial deste trabalho, por qualquer meio convencional ou eletrônico, para fina de estudo e pesquisa, desde que citada a fonte.

Catalogação na Publicação

Serviço de Biblioteca e Documentação

Faculdade de Filosofia, Letras e Ciências Humanas da Universidade de São Paulo

Gonçalves, Marcos Tadeu Fabris

Correspondências: arte, técnica e processo histórico /

Marcos Tadeu Fabris Gonçalves ; orientadora Maria Elisa

Burgos Pereira da Silva Cevasco. - São Paulo, 2011. 316 f. ; il.

Tese (Doutorado) - Faculdade de Filosofia, Letras e Ciências Humanas da Universidade de São Paulo.

Departamento de Letras Modernas. Área de concentração:

Estudos Linguísticos e Literários em Inglês.

1. Arte. 2. Cultura. 3. Pintura - França. 4.

Fotografia. 5. Atget, Eugène, 1857-1927. 6. Weegee, 1889-1968. I. Título. II. Cevasco, Maria Elisa Burgos

Pereira da Silva. 
Nome: GONÇALVES, Marcos Tadeu Fabris

Título: Correspondências - arte, técnica e processo histórico.

Tese apresentada ao Programa de Pós-Graduação em Estudos Linguísticos e Literários em Inglês do Departamento de Letras Modernas da Faculdade de Filosofia, Letras e Ciências Humanas da Universidade de São Paulo, para obtenção do título de Doutor em Letras.

Aprovado em:

\section{Banca Examinadora}

Prof. Dr. : Instituição:

Julgamento: Assinatura:

Prof. Dr. : Instituição:

Julgamento: Assinatura:

Prof. Dr. : Instituição:

Julgamento: Assinatura:

Prof. Dr. : Instituição:

Julgamento: Assinatura:

Prof. Dr. : Instituição: Julgamento: Assinatura: 


\section{Agradecimentos}

À Coordenação de Aperfeiçoamento de Pessoal de Nível Superior (CAPES) pela bolsa de estudos concedida.

À Profa. Dra. Maria Elisa Burgos Pereira da Silva Cevasco pela orientação.

Ao Prof. Dr. Francisco Alambert e à Profa. Dra. Isabel Loureiro pela leitura atenta no exame de qualificação.

Ao Prof. Dr. Marcos César de Paula Soares e à Profa. Dra. Iná Camargo Costa pelas sugestões propostas. 


\section{Resumo}

O objetivo desta tese é identificar alguns dos momentos da tradição artística visual moderna que pretenderam mapear a ascensão, a consolidação e a devastação do projeto de modernização do ponto de vista de suas vítimas no âmbito de um mercado no qual a arte e a cultura se consolidam, em passo acelerado, como mercadorias. A partir das demandas para a arte moderna codificadas na obra de Charles Baudelaire e das conquistas técnicas sedimentadas na pintura de Gustave Courbet, Jean-François Millet, Edgar Degas e Édouard Manet, examinaremos as configurações sociais e artísticas que permitirão a ampliação do quadro dos artistas trabalhadores. Tomaremos em seguida as obras dos fotógrafos Eugène Atget e Weegee como exemplos de produções artístico-fotográficas que ao elegerem o Trabalho como a categoria central na reflexão sobre o processo de modernização em curso ampliam ainda mais os horizontes artísticos, alçando-os a instrumentos de avaliação crítica de sua hora histórica.

Palavras-chave: Estudos Culturais, pintura francesa, fotografia, Eugène Atget, Weegee. 


\section{Abstract}

The aim of this thesis is to identify some of the moments within the modern artistic tradition that intended to map the ascension, consolidation, and devastation of the process of modernisation from the point of view of its victims in the realm of a market in which culture and the arts were rapidly becoming commodities. Taking into account both the demands for Modern Art codified in the œuvre of Charles Baudelaire and the technical advances in the works of Gustave Courbet, Jean-François Millet, Edgar Degas, and Édouard Manet, we will examine the social and artistic considerations that allowed the increase in number of working artists. The photographic œuvre of Eugène Atget and Weegee will follow as examples of productions that, by electing Labour as its main theme, broaden even more the artistic horizons, making them critical instruments of their historical hour.

Keywords: Cultural Studies, French painting, photography, Eugène Atget, Weegee. 


\section{Sumário}

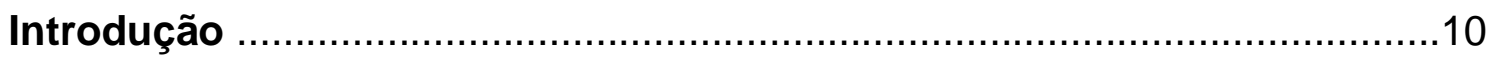

Capítulo 1: As demandas para a arte moderna ...............................15

Capítulo 2: Pintura, trabalho e a dúvida sobre o ato de ver .....................38

Capítulo 3: Eugène Atget, fotógrafo da vida moderna ..........................99

Capítulo 4: Encenação do trabalho e trabalho de encenação:

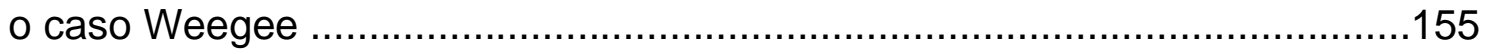

Epílogo: Outros capítulos ............................................... 268

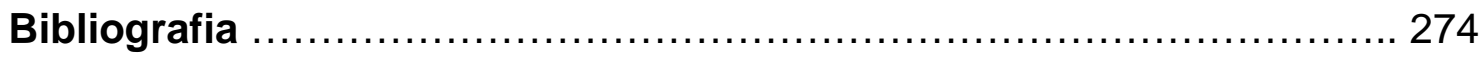

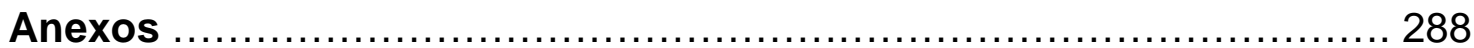




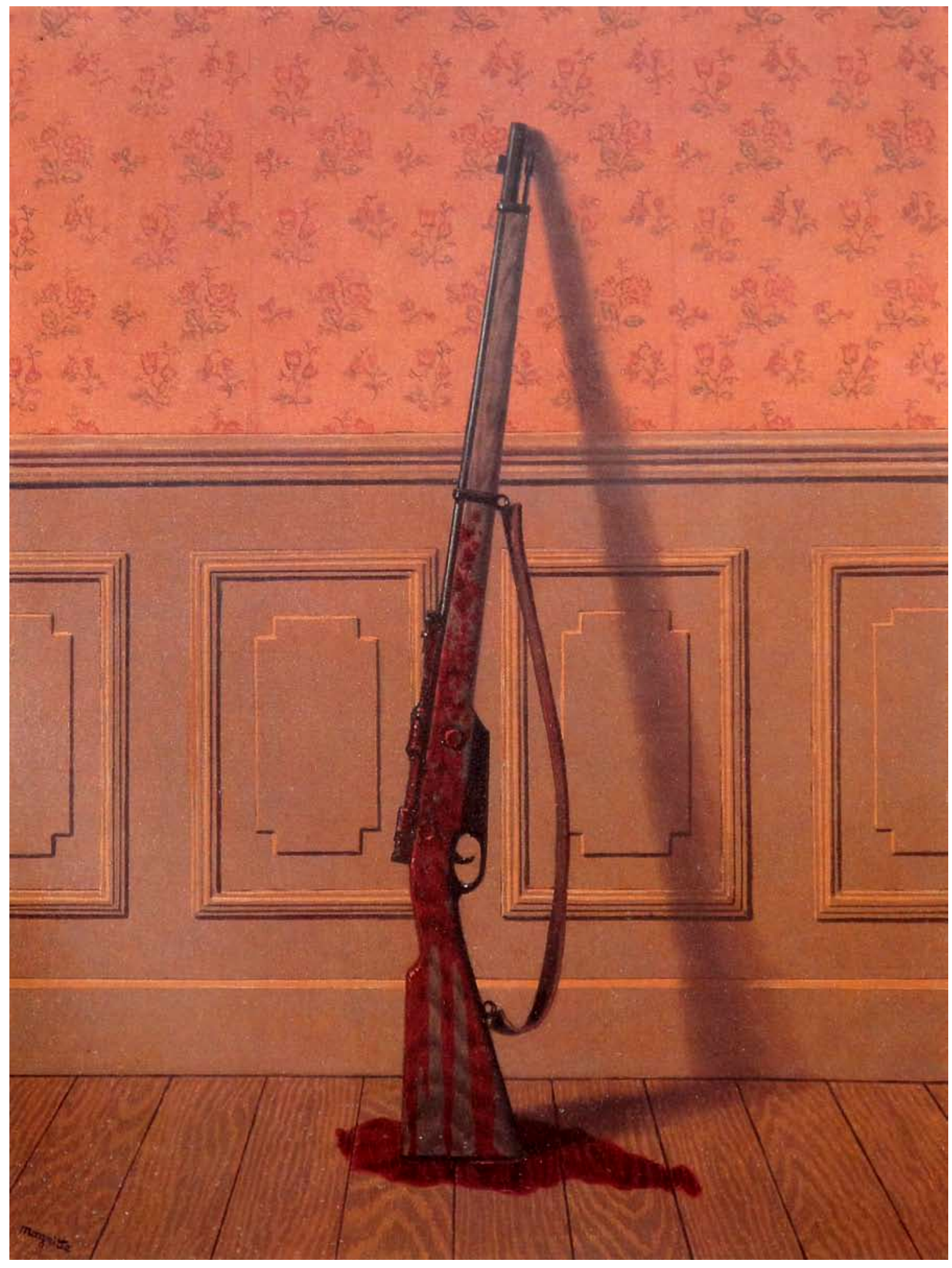

René Magritte, O sobrevivente, 1950. 


\section{INTRODUÇÃO}

Todos os envolvidos no fazer artístico que ainda hoje insistem (bravamente!) em não separar a esfera cultural da política depararão em algum momento com uma das experiências mais caras a essa tradição, aquela formulada na Alemanha dos anos trinta por Walter Benjamin. A partir do processo de transposição para o cinema da Ópera dos três vinténs do dramaturgo alemão Bertolt Brecht e, naturalmente, das decorrentes descobertas sobre a indústria na qual a cultura se transformara, Benjamin, no ensaio $A$ obra de arte na era de sua reprodutibilidade técnica, já apontara para a necessidade de perceber criticamente, como fato histórico, a redução da produção artístico-cultural à forma mercadoria.

Aprendemos aqui algumas lições importantes - e atualíssimas - sobre as relações entre as forças produtivas, ou as "tendências evolutivas da arte" e sua inserção nas "atuais condições produtivas". Em tempos de estetização da política é tarefa do artista consequente politizar a estética: se o fascismo, inclusive em suas variações atuais, exige a estetização da política, a arte política, por sua vez, deve necessariamente atacar de maneira frontal os

princípios mais caros à estética dominante, dentre os quais a subjetividade como horizonte único, o conceito de genialidade e o artista que "transcende" seu tempo para falar das questões do "eterno" e do "inefável". A proposta socialista de refuncionalização dos procedimentos do que posteriormente Theodor Adorno descreveria como "Indústria Cultural" seria precisamente a de revelar, na pura exterioridade das produções artísticas rebaixadas ao nível da mercadoria Benjamin trata aqui, não por acaso, das artes fotográficas e cinematográficas, apostando sobretudo nas qualidades revolucionárias das últimas - as condições e relações materiais de sua produção, o desperdício das forças produtivas e suas reverberações sócio-históricas neste jogo de poder.

No caso específico do cinema, em condição de ser a arte revolucionária par excellence segundo Benjamin, seus integrantes seriam forçosamente obrigados 
a se perceberem como trabalhadores de uma indústria: o filme, sendo mercadoria explícita que precisa se pagar ${ }^{1}$, acaba com a ilusão da autonomia da arte, isso sem mencionar todos os processos de divisão e racionalização da produção, que se por um lado instauram fragmentação, por outro podem potencializar ou acirrar a luta de classes, justamente graças às possibilidades de tomada de consciência por parte do trabalhador de sua condição de explorado. $\mathrm{O}$ ator de cinema (leia-se cinema mudo), reduzido a mero acessório, rompe assim com a tradição do drama burguês do século XIX. Ele ajuda a dissolver a hierarquia entre pessoas, paisagens e objetos (para citar apenas uma das possíveis ferramentas passíveis de serem utilizadas), permitindo, pelas vias de uma arte essencialmente épica (que destrói a aura do objeto artístico instaurando, portanto, outro tipo de percepção), pôr em marcha um processo de aclaramento das relações históricas, inclusive com a possibilidade de encampar conquistas adquiridas por outras áreas da experiência artística: teatro, pintura, fotografia e literatura - e ainda avançar. A compreensão do objeto de cultura seria, desta maneira, elevada da mera ambiguidade às contradições inerentes ao sistema no qual foi produzido: agora, como instrumento crítico de seu local e hora históricos, informa inclusive como o repertório técnico e artístico que permite sua criação e existência (ou seja, a tradição da qual é parte e com a qual estabelece diálogo) se realiza dentro de determinadas estruturas de poder. Ao articular tais relações, insistirá fundamentalmente na função social da arte como trabalho socialmente definido, de caráter coletivo e destruirá quaisquer ilusões sobre a separação entre atividade manual, cultural (inclusa a intelectual) e mercadoria, condição sine qua non para a definição da ação revolucionária no que diz respeito à produção artística - e eventual tomada de poder dos meios de produção pelas massas.

\footnotetext{
${ }^{1}$ Conforme explica Anatol Rosenfeld: "Ora, a Paramount não dirá a um diretor: 'Mr. [John] Ford, tome aí um milhão de dólares e vá expressar-se!' Sem dúvida, as empresas cinematográficas recorrem também a recursos estéticos. Fazem-no a modo dos comerciantes que acondicionam as suas mercadorias, antes de entregá-las ao freguês, em embrulhos bem feitos, amarrados com fitinhas cor-de-rosa ou azul celeste. Não chegam, portanto, a se oporem a uma moderada dose de elementos estéticos, mas tais aspectos se subordinam a outros interesses, geralmente alheios à arte". In ROSENFELD, A. Cinema: arte \& indústria. São Paulo: Editora Perspectiva, 2002, p. 35.
} 
No momento em que Benjamin articula seu pensamento, tanto as proposições em jogo como as batalhas políticas pareciam menos definidas (a despeito da ascensão do nazi-fascismo) se comparadas à forma como se apresentam nos dias atuais. Se a aposta socialista da apropriação dos meios de produção, inclusive os artísticos, pelo proletariado, dá ares de estar fora do horizonte neste instante histórico, como pensar hoje a cultura como ferramenta de politização no epicentro do que parecem ser os últimos capítulos do desastroso processo de modernização pelo qual passou grande parte do planeta? Como dar voz à experiência dos excluídos, vítimas desse processo, num mundo que parece ter decretado o fim da História e das lutas de classes e que agora autoriza o livre acesso a uma "nova democracia", aquela concebida e articulada nos termos do mercado de consumo?

O objetivo deste trabalho é precisamente o de identificar alguns dos momentos mais significativos de uma tradição artística que pretendeu, a seu tempo, não apenas mapear a ascensão, consolidação e devastação do projeto de modernização, mas fazê-lo a partir do ponto de vista de suas vítimas e no seio de um mercado no qual a arte e a cultura rapidamente se consolidavam como mercadorias rentáveis. A partir do processo de modernização da Paris do século XIX, examinaremos as demandas para a arte moderna feitas pelo Baudelaire de O pintor da vida moderna e as conquistas técnicas e artísticas sedimentadas na pintura de Gustave Courbet, Jean-François Millet, Edgar Degas e Édouard Manet. Tais procedimentos contribuirão, como veremos, para a criação de uma nova imagística, que dilatando as fronteiras de uma forma aos limites extremos do possível implodirá seu conceito tradicional e buscará, a partir de novas configurações, figurar a verdade estrutural de seu espaço social e tempo histórico. Ao (re)articularem um determinado conjunto de procedimentos técnicos e artísticos, que afrontarão ponto a ponto as normas engessadas prescritas pelas ciosas instituições acadêmicas (que não eram, vale lembrar, menos políticas), os expoentes desta tradição sugerem que a ampliação do 
repertório técnico-expressivo recodificado poderá, por sua natureza, ainda mais facilmente ser realizada e atualizada com a utilização dos meios reprodutíveis disponíveis, que pela maior facilidade de execução e acessibilidade oferecidas ao usuário permitirão a ampliação do quadro de artistas trabalhadores capazes de representar a experiência da modernidade. Nestes termos, também o próprio excluído poderia, com voz ativa e sem a tão temida "perda de qualidade" técnica ou estética, descrever, nos termos de um Realismo sempre atualizado, sua própria experiência de seu ponto de vista. E, se/quando o fizer, tocaria no tema central de sua existência, o mundo do trabalho e suas diversas configurações.

É neste comprimento de onda que pretendo, em seguida, considerar a obra de dois fotógrafos trabalhadores, o francês Eugène Atget, mais conhecido pelo público interessado, e o imigrante europeu naturalizado norte-americano Arthur Fellig ou Weegee, menos conhecido do público em geral (inclusive, ousaria dizer, dos estudantes de fotografia e artes visuais, sobretudo no Brasil). Ambos potencializaram as conquistas iniciadas pelo pincel e, cada qual em seu tempo, o primeiro na Paris do final do século XIX e início do século XX e o segundo na Nova York dos anos trinta, pretenderam, a partir do ponto de vista que Ihes foi facultado, escrutinar as condições de vida de todo um coletivo, elegendo a câmera fotográfica (com a utilização de procedimentos cinematográficos, como pretendo demonstrar) para conceber o Trabalho como categoria central na reflexão sobre o processo de modernização em curso, suas consequências e, creio, formas alternativas de organização social. Se Atget o faz, como veremos, modesta e "silenciosamente" em Paris, Weegee, seu "negativo fotográfico", o fará explícita e "espalhafatosamente" em Nova York. O legado destes fotógrafos, representantes de um sem número de trabalhadores em condições semelhantes às suas, surge assim com interesse renovado: tais produções, ao contrário do que repisa grande parte da crítica (mesmo aquela de esquerda, que não raro insiste em lutar as batalhas da Cultura e não aquelas do Capital), não tratam essencialmente da melancolia da alma mas, bem ao contrário, se pretendem um instrumento de avaliação crítica e ativação política dos olhares embotados 
(inclusive daqueles bem intencionados observadores contemporâneos). Os artistas trabalhadores aqui considerados deitam um olhar crítico e refletido sobre suas condições materiais de trabalho para, a partir das possibilidades encontradas, fazer o devido "ajuste de contas" com a tradição artística que os precede, atualizando, deste modo, as bases do Realismo para o que o desforme não passe por forma ideal. Acredito que os membros deste coletivo ainda podem, e devem, servir como fonte de referência e inspiração para todos os que pretendem dar continuidade a um projeto que, embora enfraquecido, se encontra distante da extinção. 


\title{
CAPÍTULO 1:
}

As demandas para a arte moderna

\begin{abstract}
"A burguesia não pode existir sem revolucionar incessantemente os instrumentos de produção, por conseguinte, as relações de produção e, com isso, todas as relações sociais. [...] Essa subversão contínua da produção, esse abalo constante de todo o sistema social, essa agitação permanente e essa falta de segurança distinguem a época burguesa de todas as precedentes. Dissolvem-se todas as relações sociais antigas e cristalizadas, com seu cortejo de concepções e de idéias secularmente veneradas; as relações que as substituem tornam-se antiquadas antes de se consolidarem. Tudo o que era sólido e estável se desmancha no ar, tudo o que era sagrado é profanado e os homens são obrigados finalmente a encarar sem ilusões a sua posição social e as suas relações com os outros homens."
\end{abstract}

A arte moderna, quando de seu surgimento "oficial" na Paris do século XIX, apresenta-se como expressão de novos arranjos sociais, decorrentes de transformações políticas e econômicas que se impunham sem precedentes na vida do período. Do ecletismo atemporal da pintura oficial da Monarquia de Julho, a arte do juste milieu, às produções que se opunham mais veementemente à arte acadêmica, as diversas práticas artísticas eram "modernas" uma vez que reagiam às condições impostas pela modernidade. Nos casos mais reacionários, celebravam na forma e no conteúdo a normatização vitoriosa do projeto burguês numa sociedade marcada pelo desenvolvimento da economia de mercado apoiada na ideologia da modernização como símbolo de progresso, com seus decorrentes aguilhões: ação individual e aceleração na produção de mercadorias, cujo intuito era

${ }^{1}$ Cf. MARX, K. e ENGELS, F. Manifesto comunista. São Paulo: Boitempo Editorial, [1848] 1998, p. 43. 
alimentar as engrenagens de tal sistema. A arte que vibrava neste comprimento de onda se colocava como um bem de consumo como outro qualquer, indissociavelmente ligada ao mercado do luxo. Quanto às práticas artísticas alternativas a essa, que pretendiam elas e que rumos tomariam para atingir seus objetivos?

Baudelaire, estimulado pela publicação dos ensaios de Diderot sobre os Salões² em 1845, inicia sua crítica de arte esboçando um "sistema" para a produção artística mais politicamente progressista. Se a burguesia, impelida pela necessidade de novos mercados, liquida todas as relações precedentes que pareciam anteriormente solidificadas, almejando a expansão em escala global do sistema que a sustenta e promovendo, para o sucesso de sua empreitada, serialização, padronização e convertibilidade, tal movimento deverá, imperiosamente segundo Baudelaire, ser formalmente incorporado na fatura da obra de arte que se pensa como verdadeiramente moderna. A máxima de Diderot "Il faut être de son temps" deve, portanto, ser atualizada: o artista dos tempos modernos é aquele que produz uma arte de vanguarda que encontra sua centralidade na sensação e no sujeito, alvos primordiais de estímulos externos. Noutros termos, a natureza como compreendida por Diderot, ou seja, um objeto de prospecção, desteologizado e desnormatizado, um sistema racional com leis internas e auto-legislador, fora colonizado pelas estruturas do capital. Por outro lado, também as idéias de liberdade, igualdade e fraternidade provaram-se historicamente indissociáveis da idéia geral de progresso que, por sua vez, compreende a livre iniciativa, o primado da propriedade privada, a exploração da força de trabalho e a obtenção de lucros. Nos ideais das Luzes encontramos, assim, uma meia-verdade ou, se preferirmos, uma verdade com "pontos cegos"; no limite, um mito. O desenvolvimento histórico do

${ }^{2}$ Cf. DIDEROT, D. Salons. Paris: Éditions Gallimard, 2008. 
Esclarecimento revelou o triunfo de seu mito, ou seja, aquele da racionalidade burguesa, desdobramento de sua lógica monetária³. Então, como buscar prospecção nesta natureza, sistema colonizado por uma lógica que, em nome da razão, articula e impõe relações irracionais? Se os ideais da Grande Revolução foram historicamente reprimidos, se a natureza de Diderot tornara-se anacrônica, o que resta da operação de subtração do coletivo no projeto original é o sujeito na sua individualidade - notícia que já fora esboçada pela pintura francesa do período anterior: pensemos na dedicatória, na assinatura, na data e na explicitação das pinceladas do David de $A$ morte de Marat, de 1793, todos indícios tanto do indivíduo retratado como do próprio artista individualizado. A partir da tradição que o precede, de Caravaggio a Hogarth, David chega nesta pintura a uma nova concepção de quadro histórico: "a história não é mais fato memorável e exemplar, tampouco drama ou episódio; é a lógica e, ao mesmo tempo, a moral dos acontecimentos."4 Examinar a lógica e a moral dos acontecimentos modernos significa examinar sem ilusões o locus social e as relações entre os homens de então, indagando-se, como na formulação original de Diderot, sobre o status e o papel do "homem de bom senso" da época moderna. E ainda, a partir de concepções diderotianas sobre a arte: como fazer com que esta seja, em plena modernidade, "apreensível e interessante como um artigo de jornal"? Como executar uma obra que prime pela expressão de idéias, pelo juízo crítico e pela inteligência do real em tempos de tamanha retração política? Diderot, uma transição para a modernidade (um "proto-realista"), lança as bases do programa que será retomado, desenvolvido e atualizado por Baudelaire.

Vemos, deste modo, que para o crítico e poeta francês, ser de seu tempo significa investigar tais questões, buscando a inteligência desnormatizada do real, a partir do sujeito, em chave de reconstrução materialista da História. Para

\footnotetext{
3 ADORNO, T. e HORKHEIMER, M. Dialectic of Enlightenment. Londres e Nova York: Verso, 1995.

${ }^{4}$ Cf. ARGAN, G. C. Arte moderna - do lluminismo aos movimentos contemporâneos. São Paulo: Companhia das letras, 2004, p. 44.
} 
tanto, o compromisso com a apreensão da realidade vincula-se agora diretamente à explicitação dos conflitos de classes (a experiência do choque moderno) e ao posicionamento político do artista frente a eles. Nestes termos, o interesse deste tipo de produção artística reside sobretudo no confronto do artista com as práticas modernas relativas à vida na cidade e as recentes formas de sociabilidade ali criadas pelas novas configurações arquitetônicas e urbanísticas, expressões da configuração contemporânea do trabalho que, por sua vez, é produto derivado do contínuo desenvolvimento do capital. A questão que se põe perante o artista é aquela da representação deste mundo, que combina efemeridade, trivialidade e tragicidade. Trata-se de figurar o amálgama de aspectos destrutivos que caracterizam um período no qual:

"o burguês torna-se autoconfiante, impertinente, arrogante, e imagina que pode esconder a humildade de suas origens e a constituição híbrida da nova sociedade elegante, na qual o demi-monde, as atrizes e os estrangeiros desempenham um papel sem precedentes, mediante meras exterioridades. A dissolução do ancien régime entra na fase final e, com o desaparecimento dos últimos representantes da velha e boa sociedade, a cultura francesa passa por uma crise mais séria do que quando recebeu seu primeiro choque violento. Em arte, [...] o mau gosto jamais ditara a moda de forma tão preponderante quanto agora. Para os novos-ricos, suficientemente abastados para querer brilhar mas não suficientemente velhos para brilhar sem ostentação, nada é dispendioso ou pomposo demais. Não discriminam na escolha de meios, no uso de materiais genuínos ou falsos, nem nos estilos que adotam e misturam. Renascença e barroco significam para eles, meios para um fim, tanto quanto o são o mármore e o ônix, o cetim e a seda, o espelho e o cristal. Imitam palácios romanos e castelos do Loire, átrios 
pompeanos, salões barrocos, os móveis dos marceneiros de Luís XV e as tapeçarias de Luís XVI. Paris adquire um novo esplendor, um novo ar metropolitano. Sua grandeza, entretanto, é com frequência apenas uma aparência exterior, os materiais pretensiosos não passam, na maioria das vezes, de substitutos: o mármore é apenas estuque, a pedra apenas reboco; as magníficas fachadas são meramente chapeadas, a rica decoração é inorgânica e amorfa. Um elemento inidôneo introduz-se na arquitetura, correspondendo à estrutura parvenu da sociedade vigente. Paris torna-se de novo a capital da Europa, não, porém, como antes, o centro de arte e cultura, mas a metrópole do mundo da diversão, a cidade da ópera, da opereta, do balé, dos bulevares, restaurantes, das lojas de departamentos, das exposições universais e dos prazeres baratos e prontos para consumo." ${ }^{5}$

Em seu ensaio $A$ arte filosófica ${ }^{6}$, Baudelaire sugere uma síntese entre romantismo (Delacroix) e realismo (Courbet, Corot) que estabeleça relações concomitantes entre objeto e sujeito, mundo exterior e o próprio artista. A esta síntese artística caberia a tarefa de figurar, ao contrário da plataforma da École de Barbizon, a vida no ambiente urbano e o efêmero nele contido - afinal, não eram nas cidades, e sobretudo na moderna Paris, que se corporificavam mais nitidamente as relações inter-constitutivas entre avanço e retrocesso, que incessantemente se consolidam e se degradam numa espécie de "presente sem fim"? Ao exigir que a pintura adote a tríade vivência do instante - não um qualquer, mas aquele com dimensão reflexiva, que se manifesta no contingente

${ }^{5}$ Cf. HAUSER, A. História social da arte e da literatura. São Paulo: Martins Fontes, 1995, pp. 788-789.

${ }^{6}$ Cf. BAUDELAIRE, C. CEuvres complètes. Paris: Éditions Robert Laffont, 1980. 
e que o ultrapassa, revelando a essência do que lhe é duradouro -, sensação e ênfase na pincelada marcada, Baudelaire edifica os pilares do que será a pintura da vida moderna.

O pintor da vida moderna ${ }^{7}$, corolário da reflexão iniciada desde O Salão de 1845, articulará os princípios de refundação da pintura que pretende dar notícia da espetacularização desta vida moderna, codificada na/pela nova linguagem visual. Trata-se assim do encontro entre pintura moderna e um mito da modernidade, a saber, o da modernização, e do confronto com a insuficiência da imagística anterior na figuração de determinados estados e movimentos, da necessidade que tiveram os novos modos de representação de conceber categorias artístico-cognitivas distintas das precedentes, partindo da expressão empírica da realidade (aparência), porém buscando, na dissolução da imediaticidade do objeto, compreendê-lo como expressão coagulada de processos materiais (essência). Esta pintura não almejaria "gerar" objetos, mas, bem ao contrário, "reconstituí-los" a partir da narrativa de suas determinações materiais e históricas. Em outros termos, apropriando-se de uma gramática da aparência que tenciona falar no e do novo idioma que se configura socialmente - e com regras bastante rígidas prescritas pela "norma culta" burguesa -, a nova pintura deveria fazer uso de determinadas categorias, mais especificamente aquelas do espetáculo e da classe, como "formas específicas de visualização"8 para a compreensão (e figuração) da ficção convincente que se tornara Paris. A partir de então, toda e qualquer permanência acrítica na "língua" realistailusionista configurará modos mais ou menos conservadores de representação da realidade.

Além do elogio ao tempo presente como objeto de cognição e ao movimento rápido que capta suas diversas expressões na vida urbana, Baudelaire valoriza o "homem do mundo" como o arauto do universo contemporâneo (por oposição

\footnotetext{
${ }^{7}$ Cf. BAUDELAIRE, C. CEuvres complètes. op. cit.

${ }^{8}$ Cf. CLARK, T. J. A pintura da vida moderna - Paris na arte de Manet e de seus seguidores. São Paulo: Companhia das Letras, 2004, p. 26.
} 
ao artista profissional, o pintor de ofício, ou, numa comparação ácida com aqueles que se pautam pela engessada normatização acadêmica, o "servo da gleba"). A arte moderna será a narrativa deste mundo por este homem. Entra em cena a figura paradigmática de Constantin Guys, o artista-repórter eleito por Baudelaire como aquele que através de sua prática artística extrai o eterno do transitório na fantasmagoria da cidade. Através da observação direta da realidade e do olhar seletivo que deita sobre a tradição que o precede, Guys sintetiza suas impressões sobre os costumes, a moda e a guerra numa formulação artística que aliava a memória sintética de sua hora histórica à rapidez de execução das obras.

Baudelaire (re)cria a figura de Constantin Guys como exemplo máximo deste artista que narra a experiência moderna, aquela do embate, e em âmbito transnacional:

\begin{abstract}
"A Bulgária, a Turquia, a Criméia e a Espanha foram grandes festas para os olhos de C. G., ou melhor, para os olhos do artista imaginário que convencionamos chamar de C.G.; pois lembro-me de vez em quando que prometi a mim mesmo, para tranquilizar ainda mais sua modéstia, supor que ele não existe." 9
\end{abstract}

Ora, se aqui o literato encontra o crítico e explicita que Constantin Guys não existe tal como figura humana mas como desiderato ${ }^{10}$, podemos supor que 0 pintor ou artista da vida moderna são, plasmados a partir da "personagem" Guys, todos os que cumprem (e atualizam) o programa baudelairiano, no qual contemporaneidade e instantaneidade encontram-se indissociavelmente ligadas. Se, a partir destes dois elementos, tal programa insiste que ao representar 0 fragmento o pintor da vida moderna estabeleça relações entre a parte e o todo,

\footnotetext{
${ }^{9}$ Cf. BAUDELAIRE, C. op. cit. p. 801 (meus grifos).

${ }^{10}$ Para semelhante interpretação ver PICHOIS, C. Baudelaire et Constantin Guys. In Constantin Guys - Fleurs du Mal. Paris: Éditions des musées de la Ville de Paris, 2002.
} 
"fabricando imagens, montando cenários e pondo o real como artifício e não como natureza"11, não teriam Baudelaire, seu personagem Guys e todos os seus sucessores, expandido o repertório das forças produtivas até então disponíveis? Não teriam eles refundado a pintura (e, como pretendo demonstrar adiante, a fotografia) e seu próprio conceito, agora essencialmente articulada nos termos de em um sistema fotográfico (e, no limite, cinematográfico), para, deste modo, re-atualizar as bases de uma nova etapa da estética realista? Escoimadas as restrições artísticas, a concepção do que era arte, e mais especificamente do que deveria ser uma arte realista, dilata-se estética e politicamente ${ }^{12}$.

Aqui, Realismo não equivale mais ao perfil fiel da realidade imediatamente visível, mas à representação de um conjunto específico de situações a partir de um determinado ponto de vista, liberto, naturalmente, dos grilhões da norma acadêmica. O caráter realista desta arte almeja desnudar as diversas redes de relações causais na modernidade, explicitando o ponto de vista dominante como aquele do dominador, para tanto adotando na prática artística o ponto de vista da classe que concebeu as soluções mais abrangentes para as questões candentes que afligiam a sociedade moderna - aquele do proletariado ${ }^{13}$. O Realismo é, assim, concebido primordialmente como um compromisso com a verdade, no qual "verdade" equivale a posicionamento do artista em relação às lutas de classes num determinado tempo e espaço históricos. Trata-se, sobretudo, de um uso profundamente político e histórico do conceito de realismo

${ }^{11}$ Cf. MARTINS, L. R. Manet - uma mulher de negócios, um almoço no parque e um bar. Rio de Janeiro: Jorge Zahar Editor, 2007, p. 12.

${ }^{12}$ A notícia da reorganização das forças pictóricas da pintura francesa é corolário do desenvolvimento histórico e materialista da França revolucionária do século XVIII; o rumo à concepção e organização de um sistema fotográfico para as artes visuais mais progressistas fora apontado pelo David revolucionário de $O$ sermão do Jeu de Paume (1791-92) e do já citado $A$ morte de Marat. Neles, a expressão do desejo e necessidade de um "Eros realista e não aristocrático" se materializa na nova economia do visível: a pintura posta como um atelier fotográfico móvel, capaz de executar a obra com rapidez, a busca de temas e assuntos nas ruas, não nos tradicionais lugares de culto - o palácio ou a lgreja - e o abandono do léxico neoclássico para fazê-lo, com apelo aos signos que invocam instantaneidade e a combinação desta nova entidade à historicidade do presente. A esse respeito, ver: MARTINS, L. R. O hemiciclo: imagem da forma-Nação. In Crítica marxista. São Paulo: Fundação Editora UNESP, 2009, n. 29.

${ }^{13}$ In WILLET, J. (org.) The popular and the realistic. In Brecht on theatre - the development of an aesthetic. Londres: Methuen, 1978. 
(e de verdade), que determinará os procedimentos estéticos mais indicados a serem utilizados pelo artista, segundo sua avaliação do estado, da natureza e das possibilidades do confronto com seu objeto em cifra histórica. Portanto o Realismo não é, de modo algum, um receituário estético ou artístico definido a priori. Como Brecht, outro grande proponente de uma nova concepção de Realismo, viria dizer:

\begin{abstract}
"Não devemos conceber o Realismo a partir de certas obras existentes. Ao contrário, deve-se empregar todos os procedimentos, os antigos e os novos, os consagrados e os inéditos, aqueles tomados emprestados da arte e aqueles que vêm de outras fontes para, assim, pôr nas mãos dos homens a realidade viva sob uma forma que se possa dominar [in such a way that it can be mastered]. [...] Realista significa: desvendar a causalidade das relações sociais [...]."14
\end{abstract}

Este Realismo alarga ao infinito o modo operatório da obra de arte pois apregoa um regime "anarquista" para as artes, ou seja, ausência de restrições de qualquer natureza, de modo que o artista possa expressar livremente sua insatisfação com seu tempo a partir da honestidade que terá com a matéria social que encontra diante de si, absorvendo-a criticamente na fatura da obra de arte para esclarecimento dos contextos sócio-históricos que a engendraram (muitíssimo distinto do uso espúrio que faria o pós-modernismo da "liberdade" que apregoa).

Nestes termos, o artista deve ser, como exigira Baudelaire, um "homem do mundo". E quem é o homem do mundo moderno senão o trabalhador! A

${ }^{14} \mathrm{Cf}$. BRECHT, B. The popular and the realistic. In Brecht on theatre - the development of an aesthetic. op. cit. p. 109 (salvo nota em contrário, todas as traduções são de minha autoria). Gostaria de apontar a distinção entre esta visão do Realismo e outra, a de Georg Lukács, bastante comum nas artes. Para Lukács, somente uma cultura do realismo em seu sentido mais estrito, nos moldes clássicos e "atualizados", poderia exprimir de modo adequado a realidade. A esse respeito, ver LUKÁCS, G. Problèmes du réalisme. Paris: L’Arche, 1975. 
"genialidade" do artista como "criatura elevada", dotada de saber ou dom especial, ímpar, deve ser substituída pela prosaica condição de um trabalhador que domina uma determinada técnica que, ao contrário do dom (ou mesmo do "estilo", a inimitável presença de um indivíduo único), pode ser transmitida, aperfeiçoada e disponibilizada; este artista assemelha-se ao trabalhador na linha de montagem. Porém, diferentemente deste, o artista que é consciente de sua condição de trabalhador ligado a relações de produção específicas conta com a possibilidade de engajar-se em trabalho não alienado: ao contrário do trabalhador que alcança pseudo-liberdade para vender sua força de trabalho num mercado que, na verdade, pressupõe forças sociais assimétricas, ele pode superar dialeticamente sua função tradicional como excrescência da modernização se levar a técnica que domina até os limites extremos do possível, implodindo suas fronteiras de tal modo a refundar o próprio conceito de arte e do fazer artístico, atingindo deste modo, mesmo que em termos ainda não efetivos, uma vitória simbólica, em conformidade com uma (sempre) nova noção de Realismo: uma arte processual, fundada numa consciência fenomênica e materialista, que deve priorizar a explicitação crítica da fabricação e dos seus nexos, ou seja, a exposição da natureza do próprio trabalho' ${ }^{15}$.

É verdade que a experiência revolucionária no campo da arte somente se completa totalmente quando efetivadas as alterações das relações de produção, ou seja, no momento em que os trabalhadores detiverem a posse dos meios de produção. Nos termos artísticos, isto significa anular a distinção entre fruição e produção artística, ou, se preferirmos, entre autores e produtores. Ao descrever o papel do escritor progressista, Walter Benjamin dá a chave para a

\footnotetext{
${ }^{15}$ Faço aqui uso da idéia de um novo realismo desenvolvido a partir da idéia de montagem e serialização na obra de Cézanne - procedimentos que poderiam ser levados a extremos pelos meios reprodutíveis, fotografia e cinema.
} 
compreensão da tarefa de todos os artistas que reconhecem sua autonomia artística - no âmbito das lutas de classes e a serviço do proletariado:

"Um escritor que não ensina outros escritores não ensina ninguém. O caráter modelar da produção é, portanto, decisivo: em primeiro lugar, precisa colocar à disposição deles um aparelho mais perfeito. Esse aparelho é tanto melhor quanto mais conduz consumidores à esfera da produção, ou seja, quanto maior for sua capacidade de transformar em colaboradores os leitores ou espectadores."16

Nas artes visuais, o "aparelho" mais perfeito posto à disposição das massas foi, até então, a câmera fotográfica. O novo meio reprodutível guarda em si a possibilidade de desestimular a separação entre artista e público, ampliando mais democraticamente o acesso à técnica e ao repertório da produção visual artística. Os possíveis procedimentos de distanciamento e de "iluminação profana"17 que comportam as artes fotográficas tornam ainda mais eficiente 0 campo de treinamento que pretende figurar a experiência do choque moderno. Acessibilidade, rapidez na execução, economia de meios e de energia para os trabalhadores-artistas: esta combinação permite desnormatizar e re-treinar 0 olhar para, através das inúmeras possibilidades de montagem que o meio permite, desembotar a percepção do homem moderno. Contemporaneidade e instantaneidade encontram-se ainda mais intimamente associadas que outrora. A explicitação de um ponto de vista construído, marca de um lugar social e

${ }^{16}$ Cf. BENJAMIN, W. O autor como produtor - conferência pronunciada no Instituto para o Estudo do Fascismo, em 27 de abril de 1934. In Obras escolhidas - magia e técnica, arte e política. São Paulo: Brasiliense, 1993, p. 132.

${ }^{17} \mathrm{O}$ conceito é cunhado por Walter Benjamin para descrever o processo da superação religiosa que alcançaram os surrealistas. Trata-se da própria idéia de pensamento crítico, de inspiração materialista, ligada ao prazer da intoxicação da descoberta e da compreensão de novas formas possíveis, desvinculadas dos modos de representação ligados à lógica e racionalidade burguesas, capazes de apreenderem determinados estágios sociais. As artes fotográficas guardam relações de interesse com procedimentos típicos surrealistas, mesmo antes que estes se configurem como projeto artístico. O caso Atget é, como veremos adiante, paradigmático de um artista surrealista avant la lettre. Cf. BENJAMIN, W. O surrealismo - o último instantâneo da inteligência européia. In Obras escolhidas - magia e técnica, arte e política. op. cit. 
portanto de classe, efetiva a crítica à modernização. A decrepitude da grande arte é finalmente consumada: ela se "degrada" em técnica.

Evidentemente a fotografia nasce no bojo de enormes disputas sociais; sua mera aparição não garantiu vitória artística, tampouco política. A mesma indústria que disponibiliza a máquina e a técnica também as "aprisiona no cativeiro das forças produtivas"18, estimulando a figura do fotógrafo como um grande artista de gênio, deslocando a discussão da "arte como fotografia" para a "fotografia como arte" 1 , tencionando manter intactas as relações de produção e repondo as regras da divisão do trabalho. Em suma, esvaziando seu potencial técnico como ferramenta crítica dos processos de modernização. Seu expoente máximo na história do meio no século XIX foi o movimento pictorialista, em suas versões europeia e norte-americana.

O pictorialismo é, na verdade, o primeiro movimento artístico constituído em torno da fotografia, marcando a história do meio fotográfico na virada do século $X X^{20}$. Floresce, em seu primeiro momento, na Europa entre 1889 e o início da primeira guerra mundial, sustentando que os "fotógrafos-estetas" - a denominação parece falar por si - deveriam acima de tudo "preocupar-se com a

${ }^{18}$ A formulação é de Iná Camargo Costa. Cf. Brecht no cativeiro das forças produtivas. In CEVASCO, M. E. e OHATA, M. (org.). Um crítico na periferia do capitalismo: reflexões sobre a obra de Roberto Schwarz. São Paulo: Companhia das Letras, 2007.

19 Enquanto a fotografia como arte liga-se à "construção mais ou menos artística de uma fotografia, que transforma a vivência em objeto a ser apropriado pela câmera", a arte como fotografia relaciona-se à "importância da reprodução fotográfica de obras de arte para a função artística." Cf. BENJAMIN, W. Pequena história da fotografia. In Obras escolhidas - magia e técnica, arte e política. op. cit., p. 104.

${ }^{20}$ Cf. Dictionnaire Mondial de la Photographie - des origines à nos jours. Paris: Larousse, 1994. 
beleza ao invés do fato"21. Assim, a (ainda relativamente precária) acuidade óptica e as capacidades reprodutoras do meio fotográfico ditas "tradicionais" leia-se "fiéis" à realidade - são percebidas como inibidores da expressão e da individualidade do artista-fotógrafo, incentivado a manipular a imagem fotográfica para atingir sua mais completa expressão artística ${ }^{22}$.

Em 1888, George Eastman lança seu primeiro aparelho fotográfico, uma pequena caixa portátil, com o slogan: "Aperte o botão; nós fazemos o resto". Estava aberta a artéria do gigantesco mercado de aparelhos e materiais, que suplantaria progressivamente o comércio das imagens. O grande público não mais compra fotografias, mas o meio de produzi-las. Surge uma nova ordem de praticantes, os amadores, para quem a produção de imagens associa-se a um instrumento de prazer através do qual registram cenas da vida cotidiana. Estes amadores, cujo surgimento vinculava-se ao desenvolvimento do processo industrial, distinguem-se dos fotógrafos amadores da década de 1850, voltados para a fotografia como arte. A fotografia artística logo se afastaria da fotografia amadora: os fotógrafos-artistas reafirmam suas pretensões estéticas, vinculamse a associações e participam de exposições para que a fotografia seja aceita no domínio da grande arte. Os demais amadores, que não reconheciam quaisquer distinções ou regras apregoadas por academias e clubes fotográficos, faziam, segundo os fotógrafos amadores estetas, parte do enorme contingente que se eximia de realizar qualquer tipo de reflexão sobre o automatismo da câmera; limitavam-se a inaugurar e fomentar um novo e fecundo filão da indústria fotográfica.

\footnotetext{
${ }^{21}$ Cf. ROSENBLUM, N. A World History of Photography. Nova York, Londres, Paris: Abbeville Press Publishers, 1997, p. 297.

${ }^{22}$ Com intuito de facilitar a manipulação de suas imagens, os fotógrafos pictorialistas europeus preferiam a utilização de materiais sensíveis que não contivessem prata, como a goma bicromatada ou carbono, para utilização de técnicas de manipulação que incluíam controle de tonalidade, inclusão de altas-luzes ou exclusão de detalhes "realistas". Utilizando os dedos, lápis ou pincéis criavam efeitos visuais que variavam da textura mais marcada à delicadeza de um tecido fino à la Japonaise. Cf. ROSENBLUM, N. op. cit.
} 
À "mediocridade" de tais imagens, libertas de controle estético ou pretensão interpretativa, limitadas a temas impróprios ou rebaixados (como a produção documentária de ordem utilitária, por exemplo a imprensa, ou imagens de natureza lúdica de cenas familiares) opunha-se uma produção fotográfica artística "séria", "consequente". Este é o chão que origina a fundação do pictorialismo: um movimento internacional, independente e sem precedentes na história da fotografia. Com a intenção de promover o reconhecimento da fotografia enquanto obra de arte, seus fundadores e seguidores reconhecem a parcela de técnica inerente ao meio, mas adotando uma "atitude artística", interpretativa e teórica nos termos que a norma acadêmica permite ou alcança, para produção de imagens que se pretendem, acima de tudo, a mais perfeita expressão desta norma.

Será deste modo que os pictorialistas articularão um duplo papel para o meio com o qual se exprimem: 1. suas imagens privilegiarão a ausência de detalhes considerados demasiadamente realistas para, desta maneira, 2. expressar 0 sentimento - a atitude interpretativa que a expressão artística deveria difundir. A competência dos fotógrafos pictorialistas europeus e a qualidade de suas produções eram então julgadas conforme suas capacidades artísticas, nunca por seu poder de descrição da realidade.

"Preocupados em ancorar a imagem fotográfica nos princípios da estética, os pictorialistas recusariam os três argumentos que, no século XIX, se opunham à ambição artística da fotografia:

1. contra o argumento que ela não poderia ser arte em função da exatidão, os pictorialistas usam o flou e a perspectiva aérea para suavizar os detalhes;

2. contra a afirmação de que a fotografia falseia os valores da natureza ao transformar as cores em preto e branco, eles 
propõem a intervenção sobre a própria prova e restabelecem os valores sobre a gradação do claro-escuro; e

3. contra a idéia de que a fotografia se reduz ao fac-símile da natureza, eles utilizaram as regras de composição diante das paisagens menos pitorescas, mostrando assim a capacidade do fotógrafo de transformá-la e interpretá-la."23

É de relevância notar que desde seu início o movimento tinha conhecimento e penetração no mercado das artes plásticas, esperando, com regras como as acima citadas - a da "boa composição", a utilização do chiaroscuro e aspirações à criação de uma "atmosfera" que invocasse sentimentos de verdade, beleza, harmonia e sugestão - conquistar colecionadores de arte, para quem qualidade estética e individualidade eram importantes considerações. As aproximações com a pintura estreitavam-se a ponto das provas fotográficas pictorialistas serem concebidas como "cópias únicas": alcançavam somas elevadas no mercado de arte precisamente porque seus negativos eram comumente destruídos para assegurar tiragem limitada, produção singular, e, consequentemente, reintrodução da aura ao objeto de arte (justamente naquela forma de expressão artística que, dado seu caráter reprodutível, a negava em sua essência e princípio!).

"A estratégia dos pictorialistas na afirmação da natureza artística da fotografia foi precisa. Forjaram uma estética que visava destruir o caráter revolucionário do seu meio de expressão. Por um lado, atacavam sua referência direta à natureza, aquilo que acreditavam ser a cientificidade fria da imagem fotográfica. Através da intervenção na cópia, a fotografia perdia sua ligação com um referente concreto e passava a evocar um lugar ideal, bem ao gosto do idealismo

${ }^{23}$ Cf. BANDEIRA DE MELLO, M. T. Arte e fotografia - o movimento pictorialista no Brasil. Rio de Janeiro: Funarte, 1998, p. 32. 
metafísico da arte romântica. Perdia também o caráter empírico da prática fotográfica do século XIX. Por outro lado, atacavam a democratização dos procedimentos técnicos e a reprodutibilidade infinita da imagem. O alto nível de sofisticação da técnica pictorialista tornava a prática fotográfica outra vez inacessível e, além disso, impossibilitava a reprodução das imagens que ficavam confinadas a uma circulação muito restrita, totalmente elitizada." ${ }^{24}$

Uma das estratégias mais eficientes concebidas pelos fotógrafos pictorialistas para reafirmar o estatuto artístico da imagem fotográfica por eles produzida, consolidar seu nicho de mercado e propagar seus ideais sobre o caráter e a natureza do fazer artístico foi a criação e disseminação de sociedades fotográficas, posteriormente denominadas fotoclubes. A condição de seus membros, os fotoclubistas, era, em linhas gerais, aquela do profissional liberal urbano que, dada sua situação financeira privilegiada, podia dedicar-se às artes fotográficas em suas horas vagas, agora com seus pares e, conforme entendiam, de forma invulgar. Essa classe média urbana logo consolidaria também um esprit de corps artístico-fotográfico e, não menos relevante, político: o burguês e o pequeno burguês agora autoreconheciam-se artistas-fotógrafos (ou fotógrafos-estetas), criando uma (auto) identidade tão forte no seio de tais instituições a ponto de disseminá-las internacionalmente - a Royal Photographic Society surge em Londres em 1853, a Société Française de Photographie em Paris no ano seguinte, o Camera Club, de Londres, em 1886 e a Fédération Nationale des Sociétés Photographiques, que reunia dezenas de sociedades fotográficas, em 1892. A existência do membro no interior de uma dessas instituições era regida em moldes semelhantes ao de sua experiência societária:

${ }^{24}$ Cf. COSTA, H. \& SILVA, R. R. A fotografia moderna no Brasil. São Paulo: Cosac Naify, 2004, p. 26. 
"A vida do fotógrafo no interior dos fotoclubes era marcada pela competição. Havia uma hierarquia que classificava os sócios dos clubes em categorias, segundo seu nível de aperfeiçoamento [tais como 'aspirante', 'novíssimos', 'júniors' e 'seniores']. Nos concursos internos os fotógrafos ganhavam pontos que eram computados juntamente com a aceitação e premiações em salões. Conforme o seu desempenho, ao final de um determinado período, ele era promovido. Havia ainda um cômputo geral, que a cada ano indicava os primeiros colocados nos diversos países e mesmo no mundo. Premiavam-se as melhores revistas, as melhores atuações clubistas e a organização dos melhores salões. [...]

A exacerbação desse espírito competitivo levou algumas vezes à organização de 'duelos fotográficos'. Os fotógrafos se desafiavam e saíam juntos com o mesmo tipo de equipamento a fim de registrar os mesmos assuntos. Depois, submetiam seus resultados a uma banca julgadora escolhida de comum acordo. Toda a tradição burguesa se fazia presente: a honra ultrajada, o desafio, a igualdade de condições e o vencedor. Em suma, esta estrutura refletia a mentalidade arrivista de uma camada social que [...] discutia a fotografia segundo os ideais românticos da 'arte pela arte' e cuja produção ocupava o lugar do lazer, do hobby de fim-desemana. [...]

Durante muito tempo esta foi a prática que caracterizou a fotografia como forma de expressão artística: uma estufa apartada do mundo, onde se cultuava a estética acadêmica e sobrevalorizava-se a técnica fotográfica. Os fotoclubistas não viviam as transformações estéticas do seu tempo. [...] Sob a 
orientação do grupo Linked Ring, fundado em Londres em 1892 e liderado por George Davison, e o Photo Club de Paris, cujo principal expoente foi o banqueiro Robert Demarchy, estabeleceram-se as bases do fotopictorialismo internacional. Com isso o movimento clubista assumiu um projeto estético que uniformizou a sua produção e definiu-lhe uma identidade. Considera-se que o auge do pictorialismo na Europa abrange o período de 1890 a 1914. Ocorre que a sua influência estendeu-se ainda por várias décadas no fotoamadorismo internacional [no Brasil o fotoclubismo já nasceu vinculado à estética pictorialista]."25

Já o momento norte-americano do pictorialismo, expressivo naquele país (e, como influência, no exterior) principalmente a partir de 1899, difere da produção fotográfica europeia, não tanto em suas influências ligadas à arte da pintura mas, em termos formais, especialmente no que tange os processos fotográficos utilizados. Os "fotógrafos-estetas" americanos preferirão aqueles que não obscureçam ou descaracterizem por demais o que consideravam a origem mecânica das imagens, numa interessante mescla entre efeitos de caráter pictórico ou gráfico e algum "realismo" fotográfico. Paisagens, retratos e a idealização da vida indígena na América eram temas preferidos, com projetos fotográficos que desde esta época contavam com apoio das altas finanças da iniciativa privada ${ }^{26}$.

Foi, no entanto, Alfred Stieglitz (1864-1946) quem "organizou" o movimento pictorialista americano no início do século XX. Espalhado e amorfo desde a última década do século XIX, o pictorialismo americano acha um centro coeso na figura deste fotógrafo que, liderando um movimento artístico-fotográfico

${ }^{25}$ Cf. COSTA, H. \& SILVA, R. R. A fotografia moderna no Brasil. op. cit. pp. $23-25$ (meus grifos).

${ }_{26}$ Edward Curtis, um dos maiores expoentes do movimento nos Estados Unidos, recebia financiamento do milionário J. P. Morgan para seu projeto de "documentação" da vida indígena norte-americana em 1899. 
intitulado Photo-Sessesion ${ }^{27}$, dá visibilidade aos expoentes do movimento em mostras realizadas dentro e fora do país. Um grupo de importantes fotógrafos pictorialistas, dentre os quais o próprio Stieglitz, expande os temas e assuntos de suas produções, das paisagens, retratos e estudos da figura humana - ainda muito populares entre os pictorialistas - para o retrato da cidade, especialmente de Nova York, sede do movimento na América. Estas imagens encontram na metrópole, em suas construções arquitetônicas como pontes, arranha-céus ou canteiros de obras a "afirmação da vitalidade da vida urbana no início do século XX; [as metrópoles eram] símbolos de poder e cultura, [...] metáforas da conquista da natureza pela inteligência humana"28; noutros termos, a quintessência da modernidade. É na segunda década do século XX que o movimento pictorialista americano perde seu vigor e influência, a despeito das tentativas contrárias de seus membros. Stieglitz, exemplo primeiro do fotógrafo pictorialista, descobrirá em sua última fase a chamada straight photography ${ }^{29}$, "subjugando a câmera com o único propósito de melhor expressão [...] com total aceitação do objeto que tem diante de si e da objetividade que o fotógrafo deve dominar, jamais dela evadindo-se" ${ }^{\text {"30. }}$.

\footnotetext{
${ }^{27}$ No final do século XIX a fotografia norte-americana, na figura de Alfred Stieglitz, impõe uma reforma aos fotógrafos amadores europeus, pioneiros da fotografia pictorialista. $\mathrm{O}$ movimento intitulado Photo-Sessession é fundado por Stieglitz e aparece em $1902 \mathrm{com}$ a exposição de mesmo nome em Nova York - era, segundo seu organizador, a "forma acabada da fotografia pictorialista". Os integrantes do movimento defendem uma arte nacional, priorizando o valor comercial das imagens no mercado artístico e a liberdade na utilização de processos fotográficos na realização da imagem final. Alguns dos principais nomes participantes do movimento incluem A. L. Coburn, F. Eugene, G. Käsebier, G. H. Seeley, E. Steichen e C. H. White.

${ }^{28}$ Cf. ROSENBLUM, N. op. cit. p. 328.

${ }^{29}$ Nos primeiros anos do século XX, Stieglitz e o grupo de fotógrafos em torno do movimento intitulado Photo-Sessession buscam, por um lado, distinguir suas obras da vulgarização das imagens produzidas por aparelhos compactos e instantâneos - já uma febre no mercado desde o lançamento da câmera Eastman Brownie pela Kodak em 1900 e, por outro, liberar a fotografia pictorialista da tutela que exercem os modelos considerados reacionários, herdados sobretudo do academicismo europeu do século XIX. Surge assim o movimento da "straight photography", título outorgado pelo crítico norte-americano Sadakichi Hartmann em seu ensaio "A plea for straight photography": uma fotografia pura, direta, que se distancia da imitação de estampas, desenhos ou composições pictóricas. O movimento ganhará força a partir de $1916 \mathrm{com} \mathrm{a}$ produção fotográfica de Paul Strand, cujas imagens serão publicadas nos últimos números da revista Câmera Work, sob supervisão de Stieglitz, associando-se ao ideal da era da máquina, símbolo de progresso e metáfora da própria modernidade naquele país.

${ }^{30}$ Cf. STRAND, P. Photography and photography and the new God. In TRACHTENBERG, A. (ed.). Classic essays on photography. New Haven: Leete's Island Books, 1980, pp. $148-149$.
} 
A fotografia, que nos seus primórdios liberara a pintura da representação "fiel" da realidade graças à sua "total fidelidade" ao referente, e muitas vezes utilizada para retratá-lo nesses termos, procura agora maior aproximação dos movimentos artísticos com vocação menos mimética, ou seja, mais "abstratos", que já nascem em busca daquilo que não é dado na superfície dos acontecimentos. Naturalmente esses movimentos trilham diversos caminhos: da tentativa de efetuar diagnósticos, almejando maior cognoscibilidade, inclusive intuindo um outro conceito de mimese - não a reprodução "fiel" da realidade, a mera cópia das aparências, mas a tentativa de representação do entendimento do artista da realidade na qual se insere à mera celebração das formas, com apelo aos sentimentos do belo e aos impulsos sensoriais, ou seja, uma experiência artística que se pretende puramente estética ${ }^{31}$. Os fotógrafos europeus do período pictorialista transitam neste continuum, muito mais próximos da segunda abordagem artística, se confrontando com uma série de tendências e influências artísticas que incluíam o Tonalismo ${ }^{32}$ e o Simbolismo ${ }^{33}$, mas sobretudo o naturalismo da Escola francesa de Barbizon e o que percebiam como seu consagrado motivo: a idealização da vida campesina, sucesso de crítica e público e tema favorito também entre os pictorialistas europeus ${ }^{34}$.

\footnotetext{
${ }^{31}$ Pensemos, por exemplo, nas produções abstratas modernistas, como o Cubismo de Picasso e Braque e o Futurismo de Marinetti, dois extremos desse continuum, inclusive para compreender que mesmo produções que se pretendem apolíticas estão a serviço de determinados interesses (no caso futurista, como se sabe, dos mais reacionários).

${ }^{32}$ O Tonalismo é um estilo de pintura em voga entre 1880 e início do século XX no qual o artista tenta capturar os efeitos visuais da luz solar no objeto retratado, reproduzindo-o com acuidade. Suas origens remontam à pintura norte-americana de paisagem, pintada com predominância de tons como o cinza, marrom ou azul, que pretendiam evocar uma certa "atmosfera" através da representação de paisagens idílicas, enevoadas.

${ }^{33}$ Este estilo artístico desenvolveu-se no final do século XIX, entre 1880 e início do século seguinte, como uma rejeição visual à produção impressionista por um lado e, por outro, à racionalidade da chamada Era Industrial. Caracterizava-se pela incorporação de símbolos e ideias, notadamente de caráter espiritual ou místico, que almejava representar a vida interior das personagens retratadas. As formas tradicionais de representação do modelo são abandonadas dando lugar a superfícies decoradas com figuras e motivos gráficos semelhantes ao mosaico.

${ }^{34} \mathrm{O}$ movimento pictorialista não produziu imagens que se identificassem com uma única estética conceitualmente definida, uma vez que, ao contrário de outros movimentos artísticos, não se constitui em torno de um único manifesto, mas dos interesses das classes dominantes. As enormes variações encontradas nesta produção, o que poderíamos identificar como "ausência de unidade formal", fazem com que seus mais expressivos membros se apresentem ora como conservadores, ora como modernistas, segundo as necessidades da hora. Tais denominações, dependendo da conjuntura, eram intercambiáveis dada a imitação de padrões e estilos da
} 
Se a vertente pictorialista europeia dedica-se à idealização da vida campesina nos termos já descritos, uma evidente reação conservadora ao crescimento e modernização das metrópoles europeias e, em termos formais, às próprias possibilidades revolucionárias da fotografia, que, neste caso, em movimento contrário, deveria apartar-se da produção massificada, "medíocre" e "liberada de controle estético e pretensões interpretativas", a vertente norte-americana parece buscar idealização de outra natureza. Nos Estados Unidos a metrópole é vista sobretudo como sinal da força e energia modernizadoras exigindo, portanto, maior "realismo" fotográfico ao representar a inovação e o progresso que chegam ao Novo Mundo. Não teria, assim, certo tipo de idealização substituído outro?

Noutros termos, a crítica pictorialista europeia ao progresso apresenta-se (se é que o faz), grosso modo, de maneira reacionária tanto em sua forma como em seu conteúdo. Ela chora a modernização propondo-Ihe uma solução imaginária, a idealização de uma vida campesina que já havia sido reduzida quase por completo a uma brutal existência. Como movimento artístico ligado aos interesses da classe dominante, não poderíamos dele esperar outra coisa: exigir a radicalização da crítica (nos termos estéticos ou políticos) à modernização, apontando para os processos de segregação dos pobres e dos excluídos, inclusive no universo da própria cultura, equivaleria a solicitar que o beneficiário de uma situação acabasse com ela. A crítica feita ao progresso pela vertente norte-americana não é menos problemática: ao enfatizar a beleza industrializada na (re)edificação das grandes metrópoles através da utilização de recursos ligados à "origem mecânica das imagens", não estaria o caráter "realista" da fotografia (também) idealizando o progresso, desta vez endossando-o do ponto de vista do próprio processo de modernização?

pintura do século XIX: romantismo, naturalismo, realismo ou impressionismo eram mercadorias que circulavam livremente pelos salões de arte aos quais essa produção fotográfica tinha acesso. Sobre a idealização que faziam os pictorialistas europeus da vida no campo, ver AUBERNAS, S. e ROUBERT, P-L. Primitifs de la Photographie - Le calotype en France 1843 - 1860. Paris: Gallimard / Bibliothèque National de France, 2010. 
Em suma, o movimento pictorialista acabava por aplainar quaisquer arestas que revelassem a experiência do choque da vida moderna, cumprindo ponto a ponto, todavia ao contrário, o programa baudelairiano. Atrela-se ferrenhamente às normas acadêmicas mais reacionárias da pintura, exigindo obediência e disciplina semelhante à militar para seus membros, repondo a distinção entre artista e público e limitando o acesso à técnica e ao repertório visual conhecido apenas aos seus pares. Dissimula e não relativiza a existência de pontos de vista, eximindo-se de desnudar redes de relações ao priorizar o caráter ilusionista da imagem, heroicizar o indivíduo e estimular a identificação com a personagem retratada. Com isso, a ênfase recai na emoção como sentimento acrítico, não como ato de conhecimento e, naturalmente, nos procedimentos artísticos internos à obra.

O instinto de auto-conservação do burguês não permite que abra mão de seu lugar como o "homem do mundo". Celebra cada vitória conquistada com o estrangulamento das possibilidades vislumbradas pelo desenvolvimento do repertório das forças produtivas: contra o Realismo, responde com formas que primam pela estruturação dramática da narrativa. Tratava-se, no caso da fotografia, da produção de obras "artísticas", revestidas por um anódino aparato ornamental que dissimula a verdadeira funcionalidade da imagem fotográfica, almejando justificá-la diante do mesmo tribunal que ela havia derrubado35; mas esta postura estética revela-se sobretudo como marca de posições políticas ligadas à união de classe $^{36}$, uma união decantada na própria produção fotográfica criada sob as regras pictorialistas. As aproximações com 0 Impressionismo (pensemos no uso indiscriminado do desfoque e do flou) não

${ }^{35}$ Cf. BENJAMIN, W. Pequena história da fotografia. In Obras escolhidas - magia e técnica, arte e política. op. cit., p. 92.

36 "[A intuição do burguês é] perfeitamente correta, de que toda arte que descreve a vida sem vieses e sem restrições é, em si mesma, um ato revolucionário. Com referência a esse perigo, o conservadorismo tem idéias mais claras do que a própria oposição. Gustave Planche declara com bastante franqueza na Revue des Deux Mondes que a resistência ao naturalismo é uma confissão de fé na ordem reinante e que, ao rejeitar-se o naturalismo, está-se rejeitando também - materialismo e a democracia da época." Cf. HAUSER, A. História social da arte e da literatura. op.cit. pp. 794. 
são fortuitas: a unificação geral da imagem impressionista - e por conseguinte da pictorialista - adquire teor estrutural, determinada em termos ópticos pela variação tonal utilizada. A aparência final da obra é a da organicidade, que reitera a idéia de duplo de uma natureza com características semelhantes. $\mathrm{Na}$ figura de um Monet encontramos a chave para a compreensão do caráter político da estética pictorialista:

\begin{abstract}
"A pressuposição impressionista, extraída de posições empiristas, de que a sensação na sua imediaticidade assinala a existência de uma unidade prévia à cisão sujeito-objeto, funda um modo de pintar dirigido para a dissolução de todo o limite, resistência ou alteridade, com a expectativa de reunificar a oposição entre sujeito e objeto pela prática estética. A ratificação do princípio clássico da unidade pictórica nas obras de Monet corrobora no plano específico da obra, como objeto de contemplação estética, a crença na unidade do sistema do qual sujeito e objeto participam."37
\end{abstract}

Mas, a despeito de seu caráter essencialmente arrière-garde, foi precisamente 0 pictorialismo, um movimento burguês, quem primeiro apontou para a vida estética, e ideológica!, da imagem fotográfica. $O$ interesse em resgatar 0 momento pictorialista da tradição artístico-fotográfica reside, portanto, no fato de que a despeito de seu caráter reacionário ou reformista, foi aqui que a mimese do real na imagem fotográfica foi, por sua constante e veemente negação, amplamente posta em xeque.

${ }^{37}$ MARTINS, L. R. Pintura e trabalho: trabalho intelectual e trabalho corporal na pintura de Cézanne, Van Gogh e predecessores. Texto não publicado. pp. 16-17. 


\title{
CAPÍTULO 2:
}

Pintura, trabalho e a dúvida sobre o ato de ver

\begin{abstract}
"Em seus edifícios, quadros e narrativas a humanidade se prepara, se necessário, para sobreviver à cultura. E o que é mais importante: ela o faz rindo. Talvez esse riso tenha aqui e ali um som bárbaro. Perfeito. No meio tempo, possa o indivíduo dar um pouco de humanidade àquela massa, que um dia talvez retribua com juros e com os juros dos juros."1
\end{abstract}

"Para além da ruptura com as poéticas opostas e complementares do 'clássico' e do 'romântico', o problema que se colocava era o de enfrentar a realidade sem o suporte de ambos, liberar a sensação visual de qualquer experiência ou noção adquirida e de qualquer postura previamente ordenada que pudesse prejudicar sua imediaticidade, e a operação pictórica de qualquer regra ou costume técnico que pudesse comprometer sua representação [...]."2

O nascimento da fotografia impõe um desafio à pintura, que deparará com pelo menos duas possibilidades distintas na trilha do fazer artístico: ou bem será uma atividade espiritual que não deverá deixar-se macular por nenhum meio mecânico (Baudelaire e os simbolistas) ou bem será, a partir de então, um problema de visão, que exigirá a distinção entre os tipos e as funções da

\footnotetext{
${ }^{1}$ Cf. BENJAMIN, W. Experiência e pobreza. In Obras escolhidas - magia e técnica, arte e política. op. cit. p. 119.

${ }_{2}$ Cf. ARGAN, G. C. Arte moderna - do lluminismo aos movimentos contemporâneos. op. cit. p. 75.
} 
imagem pictórica e da imagem fotográfica (Realistas e Impressionistas) ${ }^{3}$. No segundo caso, que nos interessa particularmente, a pintura se libertará de sua habitual ocupação, a representação do "Verdadeiro" e, ao obter o necessário alvará para expressar os valores que por outra via seriam irrealizáveis, os pintores "de visão" defrontam-se com a realidade histórica das relações recíprocas entre as duas formas artísticas, pintura e fotografia.

"É difícil dizer se era maior o interesse do fotógrafo por [...] pintores ou o dos pintores pela fotografia; o que é certo, em todo o caso, é que um dos móveis da reformulação pictórica foi a necessidade de redefinir sua essência e finalidades frente ao novo instrumento de apreensão mecânica da realidade."4

Estes "artistas de visão" estabelecem, assim, um diálogo produtivo com as artes fotográficas: apropriam-se de aspectos da linguagem do novo meio de expressão artística para, a partir deles, atualizar a idéia de Realismo, assentando a pintura em outras bases, as da "pura pintura". Ao fazê-lo, ampliam as fronteiras de seu conceito tradicional e radicalizam a crítica ao processo de modernização em marcha. A natureza e quantidade dos procedimentos que a fotografia ou o "sistema fotográfico" emprestarão à pintura (que deles se beneficiará amplamente nos casos discutidos a seguir) chegarão a tal ponto que os valores pictóricos experimentarão uma nova "qualidade". A demanda histórica que exigia a renovação da pintura, pelo menos desde o David do período revolucionário (pensemos em O Sermão do Jeu de Paume), efetiva-se: a partir de então, a crítica mais consequente à modernização e suas sequelas caberia mais à câmera que ao pincel5, já que esta faz abrir um descortino, a saber,

\footnotetext{
${ }^{3}$ Cf. ARGAN, G. C. Arte moderna - do lluminismo aos movimentos contemporâneos. op. cit. p. 79.

${ }^{4}$ Cf. ARGAN, G. C. Arte moderna - do lluminismo aos movimentos contemporâneos. op. cit. p. 75.

5 "Com a difusão da fotografia, muitos serviços sociais passam do pintor para o fotógrafo (retratos, vistas de cidades e de campos, reportagens, ilustrações, etc.). A crise atinge sobretudo
} 
maiores possibilidades de democratização da expressão e do fazer artístico, como ato sinóptico com economia de esforços que privilegia a eleição do instante decisivo e a síntese da idéia principal na concentração de significação e legibilidade da cena retratada, agora em termos reprodutíveis. Não se trata aqui de postular a "morte da pintura" como apologia de seu desaparecimento físico, mas de reconhecer que este modo de expressão artístico, em suas formas mais conservadoras, perde sua importância histórica. O que fora o princípio visual da cultura material ocidental desde a Renascença percebe-se supérfluo ante 0 paradigma de outras formas artísticas que não valorizam, ao menos em sua essência, a arte como atividade especial, fundada em bases artesanais. Tratase, portanto, de privilegiar os modos de expressão artísticos que dissolvem a arte na vida, expressões essencialmente urbanas (porque mecânicas ou industriais), que buscam figurar uma relação simbólica distinta (do olhar palaciano ou burguês) entre sujeito e objeto. Vejamos como se dá este alargamento de fronteiras na pintura francesa do século XIX examinando alguns de seus casos mais paradigmáticos: Gustave Courbet, Jean-François Millet, Edgar Degas e Édouard Manet.

Lançando as bases do Realismo em $1847^{6}$, Gustave Courbet já apontara para a força que reside na pintura, não no objeto, o que significa dizer que "mais do que

os pintores de ofício, mas desloca a pintura, como arte, para o nível de uma atividade de elite. Se a obra de arte se torna um produto excepcional, há de interessar apenas a um público restrito, e ter um alcance social limitado; além disso, a produção de alta qualidade na arte também deixa de ter função, caso não sirva de guia a uma produção média. Não mais se qualifica como um bem de consumo normal, e sim como arte malograda; tende, portanto, a desaparecer." Cf. ARGAN, G. C. Arte moderna - do lluminismo aos movimentos contemporâneos. op. cit. pp. $78-79$.

${ }^{6}$ Arnold Hauser entende que as fronteiras entre o que se convencionou chamar de Realismo e de Naturalismo são fluidas e tentar separá-las seria inútil e desorientador. O termo "Naturalismo" é empregado para referir-se a todo o movimento artístico em discussão, enquanto "Realismo" é reservado à filosofia oposta ao romantismo e seu idealismo. Não adotarei tal distinção, preferindo utilizar-me de "Realismo" ao referir-me às produções artísticas aqui consideradas. Cf. HAUSER, A. História social da arte e da literatura. op.cit. pp. $790-791$. 
representar a realidade, [a pintura] identifica-se com ela"7. Arnold Hauser ajudanos a compreender o que significa, neste caso, "identificar-se com a realidade":

"[a] fonte principal da concepção naturalista é a experiência política da geração de 1848: o fracasso da Revolução, a supressão da insurreição de junho e a tomada do poder por Luís Napoleão. O desapontamento dos democratas e a desilusão geral causada por esses acontecimentos encontram perfeita expressão na filosofia das ciências naturais, com seu caráter objetivo, realista e estritamente empírico. Após o fracasso de todos os ideais, de todas as Utopias, a tendência é agora de ater-se aos fatos e apenas aos fatos. As origens políticas do naturalismo explicam, em particular, suas características anti-românticas e éticas: a recusa em fugir da realidade e a exigência de absoluta honestidade na descrição dos fatos; empenho em manter uma conduta impessoal e impassível como garantia de objetividade e solidariedade social; o ativismo como atitude de quem está decidido não só a conhecer e descrever mas também a alterar a realidade; o modernismo que se atém ao presente como o único assunto de real importância; e, finalmente, a tendência popular tanto na escolha de assunto quanto na escolha de público."8

A Revolução de 1848 trouxe à tona pela primeira vez o trabalho como questão primordial e para os realistas franceses da década de cinquenta as implicações artísticas de 48 repousam sobretudo no compromisso de retratar o trabalho na esfera do sujeito popular. "Os quebradores de pedra" (Figura 1), tela de 1849 destruída durante a Segunda Guerra Mundial no bombardeio de Dresden, explicita a identificação da pintura com esse tema. Pessoas comuns,

${ }^{7}$ Cf. ARGAN, G. C. Arte moderna - do lluminismo aos movimentos contemporâneos. op. cit. p. 92.

${ }^{8}$ Cf. HAUSER, A. História social da arte e da literatura. op.cit. pp. $791-792$. 
mercadores, camponeses e trabalhadores já haviam ocupado lugar de destaque na representação do mundo moderno em outras obras. Aqui, no entanto, Courbet parece avançar em várias frentes: não apenas encontramos o trabalhador, mas o trabalho alienado como o assunto da pintura. Os dois trabalhadores, a criança e o adulto que quebram as pedras, são retratados como bonecos sem vida, artefatos. Como uma lente fotográfica que não obedece à tradicional hierarquia prescrita para a representação de pessoas e objetos, Courbet rebaixa o humano à condição de objeto, igualando-o aos instrumentos de trabalho por ele utilizados ou às pedras que destroem. Este procedimento permite que Courbet revele formalmente a concretude de uma determinada realidade social: 1 . sob a cuidadosa representação dos detalhes das dobras nas roupas (mais que numa musculatura idealizada à la estatuária greco-romana) registra o corpo humano engajado em esforço físico; as mesmas vestes não deixam dúvidas a respeito da origem das personagens: as camisas são ásperas, de tela ou algodão cru e as meias, rasgadas no calcanhar, chamam atenção para a relevância do detalhe; 2. sinaliza, na figura da criança, seu provável futuro espelhado na representação que faz do adulto - explicitação do fato retratado em suas dimensões sincrônicas e diacrônicas ${ }^{9}$; 3. na tipificação do sujeito (as personagens do quadro não têm rostos definidos; são "tipos" mais que "indivíduos"), embrutecido pelo desperdício de suas forças produtivas, generaliza o contexto no qual se inserem. $O$ artista representa, em última instância, os equivalentes formais de qualidades inerentes ao trabalho alienado. Este é sobretudo um quadro cujo assunto é o peso material de coisas, e assim constituídos estes trabalhadores corporificam as estruturas do mundo ao qual pertencem.

O sujeito da pintura e seu tema se confundem com a própria atitude de Courbet perante o fazer artístico normatizado, a saber, sua selvageria face à convenção

\footnotetext{
${ }^{9}$ Em cartas escritas à época da exposição do quadro, Courbet comenta a presença da criança e do adulto na cena: "neste tipo de ocupação, começamos como o primeiro e terminamos como o segundo [dans cet état, c'est ainsi qu'on commence, c'est ainsi qu'on finit]. Cf. CLARK, T. J. Image of the People - Gustave Courbet and the 1848 Revolution. Berkeley e Los Angeles: University of California Press, 1999, p. 80.
} 
e à regra acadêmica. Como as personagens em "Os quebradores de pedras", por demais absortos no trabalho de destruição do espaço e seu entorno para se ocuparem com os perplexos observadores do quadro, Courbet, alheio como eles, pretende aniquilar o espaço estreito, convencional e aburguesado ao qual a pintura havia sido confinada. Embora de natureza distinta, o velho quebrador de pedras possui enorme monumentalidade e pode mesmo ser uma referência direta ao pastor ajoelhado de Et in Arcadia ego, de 1655, de Poussin. Porém aqui o idílio é solapado: Courbet põe-se como um casseur de códigos, regras e práticas, destruidor do gosto e das hierarquias artísticas tradicionais. Noutros termos, almeja levar adiante um processo que enverga as estruturas da pintura a ponto de destruí-las: "les courber pour les écraser"10. A crítica imediatamente detecta a manobra artístico-política do artista. $\mathrm{Na}$ maior parte dos casos, almejava salvaguardar tanto os valores tradicionais da arte como a posição privilegiada do crítico como o especialista do gosto. Não por acaso Clément de Ris, crítico do L'Artiste, decreta em 1851: "as telas de Courbet fogem do domínio da arte e da crítica." 11 O que fora denunciado como "inexplicável" (o aparato crítico disponível não se provava suficiente para considerar a produção do artista) era, de fato, "injustificável", já que não se poderia analisar a obra de Courbet dissociada de seu contexto e projeto políticos. Na verdade,

"[a] fortuna satírica do quadro "Os quebradores de pedra" colaborou para a cristalização definitiva da reputação de Courbet no papel de vândalo determinado a minar os princípios da arte e liquidar cegamente seus valores. $O$ quebrador condensava todas as figuras atribuídas a Courbet, evocadas explicitamente ou recordadas de modo implícito, por ecos ou citações: o camponês calçando tamancos de

\footnotetext{
${ }^{10}$ Cf. SCHLESSER, T. e TILLIER, B. Courbet face à la caricature - Le chahut par l'image. Paris: Éditions Kimé, 2007, pp. $34-35$.

${ }^{11} \mathrm{Cf}$. ROUBERT, P.-L. L'image sans qualités - Les beaux-arts et la critique à l'épreuve de la photographie 1839 - 1859. Paris: Monum / Éditions du patrimoine, 2006, p. 123. A crítica era a mesma para o teatro ou a literatura do período que se desobrigava do cumprimento do código de regras prescritos por seus respectivos "guardiões".
} 
madeira, descomposto, negligente na aparência, sujo, um falso santo, mártir sem valor, verdadeiro charlatão. Courbet destrói a nobreza da pintura que degradava, desonrava e sujava, na sua predileção por sujeitos miseráveis [pouilleux] e crassos. Quebrava as regras da perspectiva, da composição e da mimese, por sua incompetência e inabilidade e confessou jamais ter tido por mestre outro senão a natureza e seu sentimento, pintando como desenhavam as crianças. Atrofiava ou hipertrofiava seus modelos, cultivava suas desproporções, ridicularizava a beleza e a verdade em nome do realismo. Admitindo que sua arte 'não se ligava diretamente a nenhuma tradição', parecia tudo ignorar, transformando uma Vênus em Savoyarde [habitante da região sudeste da França denominada la Savoie] para fazer dela uma banhista com aparência [allures] de bovino. Sua obra punha em cena um mundo coxo e desarticulado, caótico e desmantelado, mal-ajambrado como velhos brinquedos ou manequins brutalizados. O quebrador desnudava o impostor que era o Courbet blagueur, clamando que sua arte era 'por demais séria para se aliar ao comércio' [...]. O quebrador era assim uma figura satírica utilitária que terminou por liberar sua própria obra: o vazio. A blague era, no século XIX, uma palavra inflada e oca, agradável e enganosa, que tudo pretendia liquidar, impondo-se como uma estética da desordem, da falência, da desaparição completa e da dissolução. Esta obra de subversão, da qual Courbet será o verdadeiro criador, se encontrou amparada pelas convulsões da História que encarnou a Comuna de 1871, como regra do caos, da destruição e do vandalismo."12

${ }^{12}$ Cf. SCHLESSER, T. e TILLIER, B. Courbet face à la caricature - Le chahut par l'image. op. cit. p. 35. Deve-se fazer notar que o rechaço à regra não significa, como propusera Courbet, 
Moças à margem do Sena (Figura 2), de 1856-57, também dá notícia da quebra de hierarquia entre pessoas e objetos via utilização de uma ótica fotográfica, que, neste caso específico, se beneficia de procedimentos que simulam a utilização de uma lente tele-objetiva, evidenciando o achatamento dos planos representados (assunto ao qual retornaremos quando tratarmos dos mesmos procedimentos, radicalizados na produção de Manet):

"Mais do que apresentar uma paisagem com figuras, Courbet quis representar a atmosfera pesada, o torpor entre sensual e opressor da tarde estival, a vida puramente física das pessoas e das coisas; no gramado florido, as duas mulheres, com roupas desalinhadas, são duas flores enormes, carnosas, desabrochadas demais. São vistas de cima, os corpos quase premidos sobre a grama, belas (se tanto), de uma beleza animal e, assim como suas formas não se modelam num espaço envolvente, as cores das carnes e dos trajes também não se apresentam sobre um fundo arejado, e sim sobre o tapete próximo do gramado verde. Deliberadamente falta um centro, um eixo ordenador da visão. [...] Tudo tem a mesma importância, ou não tem importância alguma: não há razão para atribuir às figuras humanas um significado diferente do das árvores, da grama, das flores, do bote amarelo. [...] A unidade do plano de disposição (gramado-rio) e a ausência de uma arquitetura compositiva têm duas finalidades: deter a fuga do olhar em direção ao horizonte; fazer com que todas as notas cromáticas, cada qual com seu timbre próprio, se apresentem simultaneamente à atenção. [...] Os empastes de Courbet são espessos e

rejeição completa à tradição pictórica que o precede. O pintor é claramente tributário de uma tradição de renovação da pintura histórica que inclui Rubens, David, Gros, Géricault, Ticiano, Zurbarán e Rembrandt. A este respeito ver FONT-RÉAULX, D. Les ambiguïtés du réalisme pictural de Gustave Courbet. In Gustave Courbet. Paris: Éditions de la Réunion des musées nationaux, 2007. 
pesados, o material pictórico não é de forma alguma dissimulado - é como uma argila em que o artista plasma aquela coisa real, e não necessariamente agradável, que é o quadro."13

As imagens do povo oferecidas por Courbet suscitavam enorme desconforto, seja pela ampliação das cenas a dimensões "impróprias" para tratamento dos temas propostos, pondo em xeque o lugar destinado à apresentação das obras, pela representação da fealdade ou "vulgaridade" dos tipos, pela fusão de gêneros artísticos em princípio "incompatíveis", pelas referências às artes populares (estampas, caricaturas ou canções), pela justaposição de personagens aparentemente desconectados uns dos outros, enfim, pelo assunto abordado mas sobretudo pelo tratamento que o pintor lhe destina ${ }^{14}$. Todos estes aspectos são válidos para Os quebradores... ou Moças..., mas também para Após o jantar em Ornans (1848-49) (com suas referências explícitas à tradição pictórica dos irmãos Le Nains, tão cara a Diderot e, por conseguinte, a Baudelaire - pensemos em A ceia dos camponeses, de 1642), Enterro em Ornans (1849-50), Moças do vilarejo (1851) ou Camponeses de Flagey retornando do mercado (1855). Com graus distintos, percebemos em todos eles o "desfoque" da estrutura linear tradicional da narrativa normatizada, ou seja, a

\footnotetext{
${ }^{13}$ Cf. ARGAN, G. C. Arte moderna - do lluminismo aos movimentos contemporâneos. op. cit. pp. 92-94.

${ }^{14}$ A crítica conservadora jamais perdoou a ousadia de Courbert. Seu trabalho era comumente atacado como exemplo de culto ao feio ou o resultado de uma impressão fotográfica malexecutada. Étienne Jean Delécluze, ex-aluno de David, crítico de arte e um dos mais ferrenhos adversários do pintor, abertamente partidário de uma arte elitista, vitupera contra as conquistas de Courbet. Para o crítico, a arte perdia, com Courbet, seu "mistério e brilho", incorrendo em vulgarização e em tripla ameaça: 1. o público corre o risco de se deixar levar pela produção decaída, 2. o artista pode tornar-se refém deste público e, como consequência, 3. a arte se degrada de modo irremediável. A litografia, o panorama e o daguerreótipo são apontados como capítulos deste processo. Courbet é um catalisador que o acelera ainda mais, desrespeitando a hierarquia de códigos e procedimentos. O pintor Meissonier, ao contrário, é, segundo o crítico, exemplo salutar da utilização dos novos meios técnicos: representa detalhes a partir da experiência fotográfica, mas sabe guardar a devida distância entre "um mestre e seu escravo" sem jamais pôr em risco a inversão dos papéis. Noutros termos, respeita a hierarquia e o decoro acadêmicos na representação dos detalhes: nada do que for "mesquinho" (os furos nas meias dos trabalhadores, por exemplo) ou "irrelevante", aspectos que a grande Arte deve necessariamente negligenciar ou desprezar. Cf. ROUBERT, P.-L. op. cit.
} 
ausência de uma proposição inteligível nos termos da causalidade imediata (Delaroche; Gérôme), uma relativa desorientação espacial (que em casos extremos - Enterro..., por exemplo, - desloca o ponto focal de modo a exigir "cuidado" do espectador para que este não "caia" no túmulo recém aberto), uma ausência de sentimentalismo que nos identifique com as personagens e, ao mesmo tempo, uma certa literalidade do assunto representado no quadro (é o caso de Os quebradores..., o trabalho alienado). Nestes termos, Courbet polemiza com pintores canônicos como Boucher ${ }^{15}$ ou Ingres ${ }^{16}$ (que pintara Senhorita Moitessier em 1856, mesmo ano de produção de Moças...) e explicita as convenções clássicas como meras convenções, exercícios de retórica que beiram o camp. Isto porque

"Courbet está lutando por um novo tipo de homem e uma nova ordem. $[\mathrm{A}]$ fealdade de seus camponeses e trabalhadores, a corpulência e a vulgaridade de suas mulheres de classe média são um protesto contra a sociedade vigente; seu 'desdém pelo idealismo' e seu 'chafurdar na sujeira' fazem parte do arsenal revolucionário do naturalismo. Millet pinta a apoteose do trabalho físico e faz do camponês o herói de uma nova épica. Daumier descreve o burguês, sustentáculo do Estado, em sua obtusidade e insensibilidade, escarnece de sua política, de sua justiça, de suas diversões, e desvenda toda a comédia irreal que se esconde por trás da respeitabilidade burguesa. É inequivocamente claro que a escolha de motivos é, neste

\footnotetext{
15 Para referências visuais e teóricas à pintura de Bucher, ver La Volupté du Goût - La Peinture Française au Temps de Madame de Pompadour. Paris: Somogy éditions d'art, 2008. ${ }^{16}$ No caso específico de Ingres, pintor que terá seu nome intimamente associado à estética fotográfica, a distinção consiste no fato de que este, ao contrário de Courbet, busca, a partir da experiência fotográfica, "objetividade" no tratamento da informação pictórica. A fotografia na obra de Ingres não assumia outro papel senão aquele de serva, que opera nos bastidores do grande teatro que era a pintura tradicional. Em relação às possibilidades que o meio fotográfico oferecia, Ingres era um híbrido entre tradição (ou talvez arcaísmo) e modernidade.
} 
caso, condicionada mais por considerações políticas do que estéticas." ${ }^{17}$

Moças... dá notícia das convicções políticas e estéticas do pintor. Ele inaugura o tema do prazer campestre nas margens do Sena (revisto e ampliado, dentre outros, por Manet, como veremos), conferindo materialidade à experiência da vida sob o Segundo Império. Detalha as roupas das jovens e a moda (Guys, Daumier) contrapondo-as, nos termos da classe, a outras demoiselles: dialoga explicitamente com as representações fantásticas neo-rococó das fêtes champêtres da Imperatriz Joséphine e suas consortes (Winterhalter), como também com a própria representação que fez da pseudo-virtude campestre das Moças do vilarejo. As damas nas margens do Sena, pintadas como manequins articulados $^{18}$, lânguidas, lascivas, prostituídas (notemos a presença do chapéu masculino na canoa ao fundo) e com insinuações explícitas de homossexualidade e erotismo insolente são seu pendant: a resposta urbana e depravada à "virtude" rural. Não é de todo improvável que para pintar o quadro

\footnotetext{
${ }^{17}$ Cf. HAUSER, A. História social da arte e da literatura. op.cit. pp. 794-795.

${ }^{18}$ O olhar embotado do público dos Salões e o questionamento da idéia tradicional de gênero definido pela pintura acadêmica não passou desapercebido ao caricaturista e fotógrafo Nadar. Em 1857 o artista fez uma caricatura de interesse a propósito desta pintura de Coubet, cujo tema central era precisamente a desnormatização da pintura e o olhar obtuso de um público condicionado pela exigência e prescrição de regras (Nadar faz troça ao brincar com os diversos sentidos da palavra francesa "genre"). Dois burgueses observam a tela, que retrata uma boneca articulável deitada. Os parafusos em seus braços saltam aos olhos e procedem, segundo a legenda adicionada à tela, da famosa fábrica de pregos de Poissy. No texto que acompanha a imagem de Nadar lê-se: "Les demoiselles des bords de la Seine, tableau de (mauvais) genre par M. Courbet." ["Moças à margem do Sena", quadro de mau gosto/de gênero (impróprio) pintado pelo Sr. Courbet"]. Cf. Cf. SCHLESSER, T. e TILLIER, B. Courbet face à la caricature - Le chahut par l'image. op. cit. p. 77. Nadar ataca frontalmente a parcela da crítica que lamenta a perda da aura artística, delatando o Realismo como um movimento que esvazia a arte de seu princípio. Em 1849 o crítico Arsène Houssaye intitula, não por acaso, um de seus artigos "Feu Diderot" [O recém falecido Diderot], no qual questiona: "Onde está o pensamento? Onde está o sentimento? Onde está a tradição? Onde está a poesia?" Cf. ROUBERT, P.-L. op. cit. p. 124. O caricaturista e fotógrafo imediatamente compreendeu que as aproximações entre pintura e fotografia, cristalizadas na arte de Courbet salutarmente transformariam o grande artista em um artista-trabalhador consciente de sua posição, pois, com o realismo, a arte tenderia a tornar-se um ofício.
} 
Courbet tenha também se inspirado em Mulheres Malditas, poema de Baudelaire em As Flores do Ma1 ${ }^{19}$.

A obra de Courbet era, portanto, pela "brutalidade" ou "selvageria" da representação, uma espécie de versão pictórica da daguerreotipia contemporânea. As já mencionadas dimensões descomunais das telas para os gêneros escolhidos, a exatidão chocante da cena, a secura do material, a ausência de hierarquia (a força que o detalhe adquire em relação ao sujeito), a trivialidade dos temas e modelos retratados, a ausência de uma narrativa imediatamente apreensível - tudo corrobora a idéia que o artista fora marcado pelo desejo de assimilar o progresso material à sua volta na fatura da obra pictórica para, deste modo, tomar partido nas vicissitudes sociais e políticas da realidade contemporânea. O "realismo fotográfico" de Courbet não é, naturalmente, a reprodução literal da realidade. Não se trata de "cópia", mas de inventário, ou seja, o pintor se interessa menos pelo caráter da "cópia fotográfica" que por sua capacidade de adensamento da materialidade do objeto. Trata-se, portanto, menos de veracidade do que de plausibilidade: "copiar" a natureza, nestes termos, não dispensa o artista de talento. Caberá sobretudo aos meios reprodutíveis como a fotografia, capaz de apreender o traço de um passado imediato, (re)compor o sujeito histórico a partir de sua experiência com a natureza - revista e ampliada como proposta por Baudelaire. À técnica fotográfica compete a cristalização pontual deste instante - implicando

${ }^{19}$ Como um rebanho absorto e na areia deitadas,/ Elas volvem o olhar para o espelho das águas; / Os pés em mudo afago e as mãos entrelaçadas, / Bebem o fel do calafrio e o mel das mágoas. // Umas, o coração abrindo em confidências, / Nos bosques onde se ouve um córrego em segredo, / Vão soletrando o amor em cândidas cadências / E o pólen raspam aos rebentos do arvoredo;// Outras, tais como irmãs, andam lentas e cavas / Por entre as rochas apinhadas de ilusões, / Onde viu Santo Antonio aflorar como lavas / Os rubros seios nus de suas tentações; // Outras há que, ao calor da liquida resina, / No côncavo sem voz de um velho antro pagão / Pedem por ti em meio à febre que alucina, / Ó Baco, ao pé de quem dorme toda a aflição! // E outras, que adoram pôr ao colo escapulários / E que, escondendo sob as vestes um cilício, / Juntam à noite, pelos bosques solitários, / A espuma do prazer ao gume do suplício. // Ó monstros, ó vestais, ó mártires sombrias, / Espíritos nos quais o real sucumbe aos mitos, / Vós que buscais o além, na prece e nas orgias, / Ora cheias de pranto, ora cheias de gritos, // Vós que minha alma perseguiu em vosso inferno, / Pobres irmãs, eu vos renego e vos aceito, / Por vossa triste dor, vosso desejo eterno, / Pelas urnas de amor que inundam vosso peito.

Cf. BAUDELAIRE, C. [tradução, introdução e notas de Ivan Junqueira]. As Flores do Mal. Rio de Janeiro: Nova Fronteira, 1985, pp. 396-399. 
a instauração de um "antes" e um "depois" (leia-se explicitação de um processo, por oposição a estado imutável), revelando a parcela de eterno no contingente.

Os irmãos Goncourt certa vez definiram a obra de Jean-François Millet como uma síntese entre a pintura de gênero e a paisagem histórica ${ }^{20}$, o que significa reconhecer sua tentativa de substituir o sujeito aristocrático ou burguês pelo trabalhador camponês, suprimindo a narrativa dramática e teatralizada das paisagens heróicas pela simplicidade e aspereza de cenas pastoris. Em termos gerais, a afirmação procede. Os elementos que a estribam devem, porém, ser investigados, pois a obra de Millet é complexa pelo modo variável e "inconsistente" que figura, nos termos do Realismo, a experiência da vida no campo.

A propósito de uma de suas telas mais famosas, O Ângelus (Figura 3) de 1858 59, Argan observa que:

"[p]ela primeira vez apresenta-se um lavrador como protagonista da representação, como um herói moral. Porém ainda que sincera, a escolha política de Millet é ambígua: por que os camponeses e não os operários de fábricas, cuja miséria era ainda mais negra? Porque o operário já é um ser arrancado de seu ambiente natural, tragado pelo sistema, perdido; o camponês está ligado à terra, à natureza, aos modos de trabalho e vida tradicionais, à moral e à religião dos pais. Como se vê em $O$ Ângelus: um quadro que, exposto em 1867, alcançou enorme sucesso, logo passando para os

${ }^{20}$ Cf. WALLENS, G. La nature avant Barbizon. In L'école de Barbizon - Peindre en plein air avant l'impressionisme. Lyon: Musée des Beaux-Arts, 2002. 
almanaques e os cartões postais. A burguesia se entusiasma com Millet por pintar os camponeses, que são trabalhadores bons, ignorantes, sem reivindicações salariais nem veleidades progressistas; mas Millet expia seu erro político dando, como pintor, um passo para trás. Regride do Realismo ao Naturalismo romântico; escolhe conteúdos "poéticos", ama as penumbras envolventes que unem figuras e paisagem, os efeitos sugestivos da luz, os motivos patéticos."21

Millet de fato transita entre estilos ao longo de sua carreira. Nascido numa família de pequenos proprietários rurais de Gruchy, vilarejo próximo a Cherbourg, o pintor inicia seu treinamento artístico com o retratista local Mouchel e, posteriormente, com um antigo aluno de Gros, Langlois. Em 1837 obtém uma bolsa dada pela cidade de Cherbourg, que lhe é retirada dois anos mais tarde após sucessivos fracassos no Salão. Partirá então para Paris para estudar na École des Beaux-Arts no atelier de Delaroche. Até então a produção artística de J.-F. Millet encontra-se em formação, mais em conformidade com os padrões acadêmicos da pintura do século XVIII de um Boucher ou de um Greuze (como em Retorno aos campos, de 1847). Travará mais tarde contato com produções mais progressistas: Thomas Couture e os quadros de gênero expostos no Salão por Pierre Narcisse Diaz de la Peña, que Ihe trarão uma pincelada mais livre e viva para a representação de sujeitos simples e "realistas". Seu interesse pelo Trabalho como tema da pintura se mostrará presente e será uma constante em sua carreira, tensionando, durante toda sua vida, os rumos e o caráter de sua pintura entre dois "tipos" de produção: uma pintura mais tradicional e outra, mais progressista, na qual descreverá a vida num campo em vias de modernização.

É, portanto, correto afirmar que uma parcela de sua produção é composta por "conteúdos poéticos", pela ênfase em "penumbras envolventes" e pela busca da unificação cromática geral da cena retratada, incluindo, como apontara Argan, a

${ }^{21}$ Cf. ARGAN, G. C. op. cit. p. 71. 
"coesão" ou "comunhão" entre a figura humana e a paisagem. É certamente o caso de Agricultores ajuntando feno, de 1850 (Les Botteleurs), tela na qual o gesto é representado por si e para si e a idéia do sublime campestre prevalece sobre a ubiquidade do trabalho campesino. As palavras de Baudelaire para Millet não são lisonjeiras: este estilo "Ihe traz mau agouro. Seus camponeses são pedantes que têm de si uma auto-imagem por demais positiva"22. Mas a representação da natureza e do trabalho em Millet não se restringirá apenas à utilização de efeitos estéticos: no período da Segunda República ele buscava um estilo que abarcasse algumas das grandes conquistas que experimentara, não apenas na produção de desenhos e gravuras, como também na própria pintura a óleo, ao mesmo tempo em que produzia, por pura necessidade de sobrevivência, obras direcionadas especificamente ao mercado de arte, sobretudo na França e nos Estados Unidos.

Alfred Sensier, primeiro biógrafo e amigo do artista, comprava diretamente do pintor as obras que revenderia a colecionadores interessados. A partir de fotografias de camponeses, Millet produzia, por exemplo, desenhos, que por sua vez, destinavam-se a serem fotografados e vendidos como "estampas originais" "23. Sensier, com vistas no mercado, sugeria técnicas de composição e criação e estimulava uma produção que privilegiasse sobretudo cenas intimistas, sentimentais, bucólicas ou domésticas, com crianças ou animais, palatáveis ao gosto popular pela fácil compreensão e recepção (Garenne ao amanhecer, de 1867). Em suma, a tônica da produção era o mundo rural cândido e laborioso, cuja existência humana aparece intimamente ligada aos ciclos das estações, à natureza, à terra e à felicidade simples do homem do campo, que lembra com nostalgia as benesses de sociedades pré-industriais numa espécie de paysage intime. A crítica que se debruçou sobre a pintura de Millet não tardaria a consolidar a idéia de uma obra que se forjava, essencialmente, no seio de um "realismo ingênuo".

${ }^{22}$ Cf. BAUDELAIRE, C. Salon de 1859. In CEuvres complètes. op. cit. p. 776.

${ }^{23}$ A esse respeito, ver HERBERT, R. L. Millet et la photographie. In L'école de Barbizon Peindre en plein air avant l'impressionisme. op. cit. 
Já no início do século XX, o crítico, novelista e dramaturgo da escola naturalista Octave Mirbeau, ao comparar Camille Pissarro com seu predecessor, enfatizava o caráter sentimental em Millet: os gestos abruptos e violentos para os quais o pintor apelava, diminuindo o trabalhador rural mesmo quando pretendia enobrecê-lo, além de sua inabilidade em relacionar a experiência do camponês em primeiro plano e a paisagem representada ao fundo ${ }^{24}$. Bem mais tarde, John Berger também apontaria os graus distintos de "fracasso" do pintor ao tentar relacionar figura e fundo na representação a óleo (mas não no desenho): o insucesso de Millet seria flagrante graças à escolha da técnica utilizada. Para Berger, o caráter monumental das figuras recusa a pintura e vice-versa. Como resultado, as silhuetas recortadas parecem hirtas e teatrais (como em $O$ semeador); o momento retratado é demasiado longo. Seu malogro consistiria, pois, precisamente no fato de que a linguagem tradicional da pintura a óleo não consegue acomodar o sujeito que Millet traz consigo, ou seja, o interesse do camponês pela terra e sua relação de trabalho com o campo, em teoria incompatíveis com a maneira como a terra é representada em termos formais. Berger sustenta seu argumento lembrando, em outro lugar ${ }^{25}$, que a pintura a óleo, com sua vastíssima gama de cores, tons e possibilidades de representar texturas, apresentava-se, desde seu surgimento no século XVI, como técnica para a reprodução fiel e exata do mundo visível, consolidando-se, antes do advento da fotografia, como o próprio ato de ver. Segundo o crítico, num momento em que a burguesia se firmava como grupo social, impondo sua visão de mundo e suas práticas relativas ao dinheiro e ao comércio, a técnica da pintura a óleo nascia precisamente para dar forma a estes novos conteúdos sócio-históricos, incapazes de se materializarem em termos visuais em técnicas anteriores como o mosaico, a têmpera ou o afresco, que não conferiam, de modo tão tangível, quase palpável, o lustre e a solidez desejados ao objeto retratado. A pintura a óleo celebrava, deste modo, o novo tipo de riqueza, de

\footnotetext{
${ }^{24}$ Cf. SHIFF, R. Pissarro: Dirty Painter. In Camille Pissarro - Impressions of City \& Country. New Haven e Londres: Yale University Press, 2007.

${ }^{25}$ Cf. BERGER, J. Ways of Seeing. Londres: British Broadcasting Corporation \& Penguin Books, 1972.
} 
caráter dinâmico, que encontrava sua recompensa no poder de compra do dinheiro. Deveria conseguir demonstrar visualmente o que poderia ser comprado, e o desejo do que podia ser adquirido estava precisamente na capacidade que a técnica oferecia de conferir materialidade ao objeto. A técnica de pintura a óleo, aponta o crítico, é o primeiro capítulo no processo de educação do olhar do expectador moderno, e fará às aparências o que o capital faria às relações sociais: reduzir tudo à qualidade de objeto, à forma mercadoria, sendo toda a realidade visível apreendida e mensurada por sua materialidade. $O$ argumento de Berger, no geral bastante arguto, parece desconsiderar que as "limitações" na obra de Millet não são de modo algum intrínsecas à técnica da pintura a óleo, que não encerra em si a impossibilidade de dar voz à experiência dos excluídos (como fizera Courbet ou, como veremos adiante, o próprio Millet, além de Degas e Manet) ${ }^{26}$. A partir de As respigadeiras, também Linda Nochlin apontou, como Marie-Pierre Salé27, o réalisme naïf de Millet e a ausência de conflito histórico na obra do pintor, cujo intuito seria o de "enobrecer as poses e aproximar as figuras [femininas] de protótipos clássicos ou bíblicos, removendoas de seu contexto politicamente carregado da história contemporânea, representando-as num contexto trans-histórico da alta cultura"28. Não creio, todavia, que a idealização que Millet fazia da Natureza e do Trabalho, seu suposto "realismo ingênuo", era produto de restrição da técnica, de incompetência artística ou de obtusa mentalidade face à experiência da vida no campo (a tensão entre o caráter trágico e ao mesmo tempo banal que adquirira ali o trabalho). Sua busca e dificuldade de figuração de uma experiência que fosse tão intimamente familiar quanto amargamente ressentida não eram exclusivamente de ordem estética, mas material e política.

"As dificuldades de Millet não eram simplesmente estilísticas.

Ele tinha motivos de sobra para dissimular sua real direção,

\footnotetext{
${ }^{26}$ Cf. BERGER, J. Millet and the peasant. In BERGER, J. About Looking. Nova York: Vintage International, 1991.

${ }^{27}$ Cf. SALÉ, M.-P. Dessins de Jean-François Millet. Paris: Musée d'Orsay, 2006.

${ }^{28}$ Cf. NOCHLIN, L. The Cribleuses de blé: Courbet, Millet, Breton, Kollwitz, and the Image of the Working Woman. In Courbet. Nova York: Thames \& Hudson, 2007, p. 101.
} 
fazendo concessões propositadamente, produzindo o que dele se esperasse. Era pobre e a revolução o deixou ainda mais pobre. [...] Não havia dúvida sobre suas finanças em 1848: já era pintor havia quinze anos, nove dos quais em Paris, mas ainda vivia numa hospedaria - mais ou menos uma favela - com sua companheira e filhos ilegítimos, tendo que produzir especificamente para o mercado. [...] Em 1851 fazia letreiros para lojas elegantes e desenhos para livros sobre o velho oeste. [...] Todo esse período foi uma luta por dinheiro e fregueses: Millet fazia qualquer serviço que the aparecia pela frente. ${ }^{29}$

Tanto quanto the permitiam as condições materiais, o trabalhador camponês ocupa o centro da representação na obra. Entretanto, sua experiência social não se resume apenas àquela do camponês ligado à terra pela tradição e pelos valores morais ou religiosos pois o próprio campo passava por significativas transformações econômicas, assim como a banlieue e a cidade. Além do mais, fazia parte do imaginário urbano da época a idéia de campo como o espaço antagônico à metrópole, reduto da ignorância de camponeses que personificavam o protótipo da estupidez ${ }^{30}$. A contribuição que Millet parece ter dado à pintura, em sua produção menos convencional iniciada em Paris e portanto anterior a sua partida para Barbizon (1849), dá notícia dos processos de modernização no campo e seus aspectos inter-constitutivos com aqueles que tinham lugar na cidade, no faubourg e na banlieue. Noutros termos, Millet concebe o trabalho e o trabalhador rural como o duplo do urbano, substituindo a representação poética da vida rural por uma reflexão da experiência de ordem materialista.

\footnotetext{
${ }^{29}$ Cf. CLARK, T. J. The Absolute Bourgeois - Artists and Politics in France 1848 - 1851. Berkeley, Los Angeles e Londres: University of Califórnia Press, 1999, p. 75.

${ }^{30}$ Cf. MANCEUVRE, L. Jean-François Millet - Pastels et dessins. Paris: Bibliothèque de l'Image, 2002.
} 
"[O mundo de Millet] fora definido antes de Barbizon, pintado às margens do Sena, nos subúrbios industriais de Paris. [...] Parece correto afirmar que as primeiras camponesas de Millet eram mulheres do subúrbio, da banlieue, aquela terra-deninguém das fábricas e do cultivo, que contornava a Paris de meados do século XIX, e que servia de habitação para as chamadas classes dangereuses". [...] Uma vez em Barbizon, a imagem do camponês feita por Millet passara por inúmeras transformações, porém aquela primordial, a fisionomia tipicamente selvagem [de suas personagens], fora definida em Paris. [...] Uma coisa é certa: em meados do século XIX a floresta não era o lugar ideal para procurar pelo idílio. Lenhadores e trabalhadores rurais lutavam por sua sobrevivência, frequentemente de maneira violenta [...]. Eram [...] o proletariado das florestas: homens sem terra que dependiam dos feixes que suas esposas amealhavam na mata, da criação de porcos ou vacas feitas nas cercanias dos bosques e do direito de respigar obtidos pelas mulheres em épocas de colheita. Paulatina e consistentemente, muitos desses direitos foram suprimidos: respigar foi proibido por lei e guardas florestais espantavam o gado. Os camponeses revidavam com incêndios, ataques ou qualquer outro subterfúgio, aguentando o quanto podiam até partir para as pedreiras e fábricas parisienses. As pinturas de Millet, especialmente aquelas feitas a partir de 1853, são um retrato fiel tanto da luta pela sobrevivência dos camponeses como de sua desesperança." ${ }^{31}$

${ }^{31}$ Cf. CLARK, T. J. The Absolute Bourgeois - Artists and Politics in France 1848 - 1851. op. cit. pp. 77-78 (meus grifos). 
Nesses termos, teria de fato Millet "regredido", no todo de sua obra (a comparação proposta é entre os "dois" Millets), para um "Naturalismo romântico"? Acredito que uma possível resposta se encontre no percurso que vai de Agar e Ismael, de 1848-49, à segunda versão de O semeador, de 1850. Em Agar... (Figura 4) Millet depura seu estilo: as duas personagens retratadas numa paisagem árida, um deserto, são representadas em posições curiosas e desconfortáveis. A primeira, Agar, aparece deitada e um tanto contorcida na areia, ocupando quase todo o primeiro plano da imagem. Ismael, na transição entre o primeiro e o segundo plano, é retratado em abrupta "perspectiva", enfatizada pelo jogo de luz e sombra. O pintor dialoga formalmente com parte da tradição que o precede, da pintura clássica que lhe fora ensinada em Cherbourg (no jogo formal de luz e sombra) ao ideal clássico (o modelo ético) de David (de A morte de Marat, de 1793 e A morte de Bara, de 1794; pensemos nas figuras em primeiro plano, demasiadamente aproximadas do espectador, tendo ao fundo uma paisagem "neutra", e no caráter heróico e exemplar que assumem as duas personagens ${ }^{32}$ ). Em Agar... o passo adiante dado por Millet parece ser precisamente aquele ligado à representação do espaço, que subverte o uso tradicional da escala e das distâncias, tornando-as incertas. Como? Ao retratar o deserto e suas distancias ambíguas, o pintor não apela para a descrição quadro a quadro, uma vez que no deserto não há senão o próprio espaço. Ao justapor as duas figuras sem os tradicionais indicadores espaciais (árvores, paisagens, etc.) sugere simultaneamente espaço e superficialidade, um espaço que é acima de tudo inferido, um "pano de fundo".

Reordenar o espaço pictórico rompendo com a representação perspéctica tradicional e suprimindo a descrição quadro a quadro significa reordenar a narrativa que a pintura pretende tecer. $O$ convencionalismo característico da produção comercial de Millet dá lugar a novas formas artísticas e narrativas:

32 Para considerações e análises específicas das duas obras de David aqui citadas, ver: MICHEL, R. e SAHUT, M.-C. David - L'art et le politique. Paris: Découvertes Gallimard et Réunion des Musées Nationaux, 2003. e MICHEL, R. Bara: du martyr à l'éphèbe. In La Mort de Bara - de l'événement au mythe. Autour du tableau de Jacques-Louis David. Avignon: Fondation du Muséum Calvet, 1989. 
entram em cena a justaposição de figuras que não mais ilustram uma tarefa nem motivam reações causais umas nas outras, a insistência na representação das personagens como tipos mais do que como indivíduos particularizados, a completa ausência de "pretensão filosófica, melancólica e rafaelesca" ${ }^{\text {"33 }}$ das personagens, que, na total ausência do sublime poético das obras encomendadas, ganham peso e materialidade. São corpos maciços que sofrem a ação da gravidade, coisas com as quais o observador trava um embate mais físico que espiritual. A pincelada aponta para si e a tinta nomeia-se enquanto tal, na paisagem, pela sequencialidade do gesto repetido e metódico, metáfora do próprio trabalho (que seria levada a extremos por Cézanne) e nas figuras, pela distinta notação pictórica utilizada para os corpos, que primando por um efeito geral de certa "granulação", explicita o grau de recusa experimentado pelas personagens em relação à paisagem, que não as "absorve". A tragicidade da história de Agar e seu filho, expulsos do Egito por um Abraão submetido aos caprichos da esposa, ganha na tela de Millet contornos materiais e contemporâneos. Quais?

Na própria escolha do tema, Agar... já aponta para a transição que culmina em $O$ descanso dos lavradores (Figura 5). Ao evocar a passagem bíblica que narra a expulsão de Agar e seu filho da casa de Sara e Abraão, suas dificuldades em sobreviver à travessia do deserto e a visita inesperada de um anjo, que como um deus ex machina salva a criança da morte oferecendo-Ihe água no momento mais dramático da trama para que esta se torne, posteriormente, o pai de todos os árabes que vivem no deserto, um povo livre, jamais dominado por qualquer outro, vivendo segundo suas próprias leis e desejos (num mundo reconciliado com direito a "happy end"), Millet esboça, alegoricamente, a notícia de uma situação social que Ihe parece injusta, a circunstância do trabalhador camponês, numa imagem em espelhamento invertido à narrativa bíblica. Em $O$ descanso... irá radicalizar a idéia: a situação social sugerida em Agar... é explicitada e localizada no trabalho, imerso na História. Retoma a paleta monocromática em

${ }^{33}$ Cf. BAUDELAIRE, C. Salon de 1859. op. cit. p. 776. 
tons de marrom, que imprime à cena uma soturna e melancólica atmosfera, "como se o camponês fosse pintado com a própria terra que semeia"34.

A partir daí, grande parte de sua produção avançaria, como anteriormente mencionado, no sentido de dar voz à experiência daqueles que haviam se tornado os "proletários da floresta", radicalizando tanto a tipificação da figura do camponês trabalhador como a atribuição de significados às formas de representação do homem e da paisagem, reiterando a clivagem entre figura e fundo.

"Millet sabe extrair o caráter essencial de sua observação dos camponeses e seu trabalho. O que o comove é a beleza de seu gesto, sua força, sua concentração, seu cansaço ou seus sonhos. É a convicção com a qual executam suas ações. Nesses termos, Millet cria personagens [...] tipificados. [...] A própria composição é agora distinta. Em Barbizon, os camponeses ocupavam lugar central nas composições, como em As respigadeiras, e a paisagem parecia servir para contextualizar seus habitantes. A partir de 1865, Millet atribui à paisagem importância cada vez maior: os homens e a natureza têm a partir de agora importância semelhante. Isto é particularmente evidente em $O$ poço de Dôme [Le puy de Dôme] [... $]^{33}$

Voltemo-nos agora a $O$ semeador (Figura 6), que leva a extremos as conquistas de Agar... e de $O$ repouso... . A segunda versão da pintura enfatiza ainda mais a imagem embrutecida do trabalho campesino. Em relação à primeira versão, os contornos do trabalhador são de alguma maneira suavizados, a figura é menos

${ }^{34}$ É assim que Van Gogh define a pintura de Millet, em carta endereçada ao irmão Theo. Cf. FIELD, J. Peasant life: les paysans chez eux. In VAN HEUGTEN, S. [et alii]. Van Gogh and the colours of the night. Nova York: The Museum of Modern Art, 2008, p. 102.

${ }^{35}$ Cf. ROUX, N. e GILBERT, F. Jean-François Millet - Voyages en Auvergne et Bourbonnais - 1866-1868. Clermont-Ferrant: Skira / Seuil, 2002, p. 71. 
monumental e a pose do corpo é retratada um tanto mais empertigada, enrijecida e mecânica. A parte superior do corpo, que se posiciona por demais para trás em relação às pernas, demasiada e dolorosamente retorcidas, não se "encaixa" na parte inferior do homem. O braço hirto, a mão tensa e o gesto automático indicam uma certa contenção de energia. A bolsa de grãos que leva junto ao corpo chama atenção pelo modo como foi pintada: as pinceladas e as cores empregadas a tornam um bloco maciço, destacado fisicamente do corpo do homem como um objeto que lhe é alheio. O trabalhador encontra-se mais ao centro da tela, "congelado" em sua ação, confinado no exíguo espaço retangular que o aprisiona. A linha do horizonte, que se encontra fora de seu eixo característico dado o declive do terreno, reforça a sensação de desequilíbrio e alienação. Para épocas de plantio, a paisagem é acre e desoladora; corresponde à figura retratada mas não estabelece com ela qualquer trânsito: 0 camponês mais parece uma estampa, um decalque veementemente repugnado pelo fundo (em graus distintos, podemos afirmar o mesmo para Homem com arado, de 1863). A ação mecânica e repetida, o gesto automatizado, a tarefa que subjuga o trabalhador, embrutecendo-o, cristaliza a própria noção de trabalho alienado. Confinado e restrito, o semeador combina fraqueza e (alguma) asseveração, num complexo de engrenagens no ou pelo qual se é esmagado - uma metáfora utilizada por um Millet consciente tanto de seu local social como das mais diversas restrições impostas à produção artística consequente, ao definir, nos termos industriais, o próprio fazer artístico.

É certo que a produção pictórica de Barbizon - inclusa esta parcela da obra de Millet - é uma reação ao processo de haussmannização de Paris. Porém, ao contrário da insistência de parte da crítica ${ }^{36}$, a "fuga" para o campo, a reação à degradação social e urbana e a negação do processo de modernização nos moldes "nostálgicos", pela valorização de uma Natureza apartada da vida

\footnotetext{
${ }^{36}$ Cf. ROSENFELD, D. The Spirit of Barbizon. In The Spirit of Barbizon - France and America. São Francisco: The Art Museum Association of America, 1986. e HERBERT, R. L. City vs. country: the rural image in French painting from Millet to Gauguin. In From Millet to Léger Essays in Social Art History. New Haven e Londres: Yale University Press, 2002.
} 
urbana, ou, noutras palavras, a Natureza dissociada dos processos sociais, políticos e econômicos, uma Natureza mais "perene" que a Política, não justifica ou explica a fração mais engajada da obra de Millet.

Um breve paralelo de sua produção com aquela de Rosa Bonheur (1822-1899), sua contemporânea e outro expoente na representação de cenas campestres, ilustra o argumento. Um de seus trabalhos mais famosos, a tela Lavragem em Nevers: primeira lavra de vinha (Figura 7), de 1849, é típico do conjunto de sua obra e instrutivo como termo de comparação. O pitoresco ausente no semeador de Millet é aqui presença marcante. Trata-se da "representação simples de um fragmento do mundo tal como se the apresenta aos olhos, [...] a transformação de uma cena banal numa visão de repousante beleza" ${ }^{37}$. Este ponto privilegiado de observação é a marca de sua visão apriorística da natureza. Ao contrário de O semeador, o ponto de vista é aquele do espectador que consome a paisagem à distância, como imagem de idílio campestre que teria um suposto visitante ou turista citadino. Todavia, a insistência na representação minuciosa da exploração planificada dos recursos naturais e do trabalho campesino, na figura do arado, dos animais, da terra e dos trabalhadores em suas mais características particularidades e detalhes, explicita não apenas a metáfora visual que é a tela para o poder "sublime" e a "magnitude" da natureza, mas a concepção do triunfo das campanhas de modernização do campo pelo cultivo racional da terra, vistos do ponto de vista do proprietário, que vigia seus negócios e que detém os meios de produção. A ênfase nas habilidades do desenho pelo traço marcado, na claridade da composição espacial, na vastidão do espaço e dos recursos naturais, enfim, na natureza como reservatório de forças a serem racionalmente exploradas ecoa e corrobora a idéia da Natureza domesticada, ou, por outra, esquadrinhada pela lógica quantificadora burguesa desenvolvida segundo os critérios dos processos de modernização iniciados a partir dos centros urbanos - Paris.

\footnotetext{
${ }^{37}$ Conforme a definição de "pitoresco" do crítico E. H. Gombrich. In A História da Arte. Rio de Janeiro: Editora Guanabara Koogan, 1993, pp. 329 - 330.
} 
O esplendor capitalista em Bonheur equivale à miséria física e espiritual em Millet. Desamparado e obsoleto, O semeador enfrenta um solo repleto de pedras e ervas daninhas. O arcaico guarda, aqui, os traços de um mundo que desaparece, de uma sociedade em dissolução, mas também a memória das lutas travadas e perdidas pela personagem representada (a insistência na representação de antigas ferramentas de trabalho, a meio caminho da obsolescência se comparadas às técnicas mais modernas, ratifica Millet como o "anti-Bonheur"). A parábola bíblica que possivelmente inspirou Millet, aquela do semeador (Mateus 13:24-43), ensina que "alguns escolhidos entenderão", que alguns terão a "capacidade de ver": "o campo é o mundo e a boa semente são os filhos do reino"; "os justos brilharão como o sol". Opondo-se à visão da História como a narrativa dos vencedores, Millet, ao contrario de Bonheur, identifica-se afetivamente com o oprimido, pintando o trabalhador esvaziado de sua vida interior, como um autômato. Ao representá-lo desta maneira, ou ainda, por tê-lo assim representado, revelando a ausência de sua alma, insufla-lhe espírito - mas aquele de seu tempo. É esta a ação revitalizadora que o torna vivo e ativo, o spiritus rector desta estrutura inanimada. A idéia de rememoração das lutas e promessas não cumpridas, bem como da redenção da personagem individualizada, ultrapassa as fronteiras religiosas para, a partir delas, atingir um patamar político. A teologia deste Millet não é jamais um objeto em si e para si, não visa a contemplação de verdades eternas ou reflexões sobre o divino. Bem ao contrário, põe-se a serviço da experiência dos oprimidos e destina-se a restabelecer a força explosiva, "messiânica" se preferirmos, mas sobretudo revolucionária de suas lutas. O espaço de reflexão por ele aberto põe em xeque a concepção de inferno: nestes termos, a eterna repetição daquele "mesmo" representado em $O$ semeador (Millet explicitaria a concepção moderna de inferno ao fazer paralelos entre $A$ expulsão do Paraíso, o famoso afresco de Masaccio pintado na Capela Brancacci de Florença e seu Rumo ao trabalho, de 1850-51). O campo do semeador de Millet é portanto a própria História. A partir de seu sofrimento e desolação individuais dar-se-ia simbolicamente a redenção de todas as gerações vencidas que o precedem - os derrotados de 1848 são 
ainda memória fresca $!^{38}$ - de todos aqueles com a verdadeira capacidade de "ver" e, acompanhada de sua redenção, a reparação coletiva de todo um passado, que poderia ter sido mas não foi.

Na parábola de Agar o Messias é figura central: enviado dos céus, resolve o conflito. Em $O$ semeador, o Messias não é senão a própria classe proletária e seus núcleos de resistência. É patente que sua "redenção" não é um dado, mas um processo que não está garantido e que portanto deve ser continuamente lembrado e retomado para que o inimigo histórico seja derrotado. Neste âmbito, o papel da produção artística é o de integrar, como nos ensina Millet, a história da cultura àquela das lutas de classes. A rememoração promovida da experiência dos excluídos é a necessária apocatástase do esquecimento, da qual não pode prescindir o contínuo combate rumo à emancipação e à utopia. Uma fala do ponto de vista dos oprimidos, o discurso do semeador vivifica politicamente as passagens bíblicas. Como trabalhador consciente de sua posição subalterna, Millet estava condicionado aos imperativos da produção voltada especificamente para o mercado e sabia o que isso significava. Mas a pouca liberdade artística que gozara the permitiu a expressão de formas alternativas àquelas que Ihe eram impostas. O semeador de Jean-François Millet confia na possibilidade de frutificação de um certo tipo de semente, que ao aspirar "por um secreto heliotropismo, [se volta] para o sol que está a se levantar no céu da História."39

\footnotetext{
38 "Sua visão da História era por demais passiva e pessimista para permitir-lhe qualquer conviçcão política mais forte. $E$ ainda assim, os acontecimentos entre 1848 a 1851, as esperanças que eles aguçaram - e suprimiram - estabeleceram para [Millet] e muitos outros 0 desejo pela democracia, não tanto em termos parlamentares, mas no sentido dos direitos do homem serem aplicados de maneira universal. O estilo artístico que acompanha esta exigência moderna é o realismo: realismo pois revela condições sociais ocultas, realismo pois, acreditavase, todos poderiam reconhecer o que ele revelava". Cf. BERGER, J. Millet and the peasant. op. cit. p. 79.

${ }^{39}$ Cf. LÖVY, M. Walter Benjamin: aviso de incêndio - uma leitura das teses "Sobre o conceito de história". São Paulo: Boitempo Editorial, 2005, p. 58.
} 
Edgar Degas, que também fotografava, possivelmente se valeu das artes fotográficas como meio de expressão e inspiração para sua pintura mais que qualquer outro Realista. Compreendeu que a fotografia evocava o espírito do espontâneo, do fragmentário, do imediato e, ao incorporar elementos característicos da nova técnica à pintura, contribuiu de modo decisivo para a expansão do repertório das formas pictóricas disponíveis que pretendiam tecer uma narrativa da vida sob a égide da modernidade. O caso Degas é paradigmático do artista que compreende a captura da realidade como apropriação e representação do espaço, não como uma estrutura fenomênica atemporal ou inalterável, mas como elemento de constituição histórica. Daí sua profunda dissidência com os modos de representação que privilegiam 0 emprego da perspectiva euclidiana clássica (e, neste sentido, a radicalização de alguns dos procedimentos utilizados por Courbet e Millet ${ }^{40}$.

Para compreendermos a ruptura de Degas com a secular tradição que o precede faz-se necessário considerar os modos como o pintor utiliza e subverte a técnica da perspectiva artificialis. É sabido que esta maneira de representação do espaço, que ganha fôlego sobretudo a partir do cinquecento italiano, transformara o quadro em uma "janela", a partir da qual o espectador contemplaria, graças à uma luz não mais física mas espacial, a vida "como ela é". Sua "aparência natural" torna-se a própria virtude da obra, que não mais se encontrava fora ou acima dela, mas em seu interior. A suposta "observação

\footnotetext{
${ }^{40}$ Degas era fotógrafo amador e produziu grande número de imagens, muitas perdidas ou não localizadas. Seu interesse pelo meio fotográfico residia sobretudo nas novas possibilidades de atualização do projeto realista propiciadas pela fotografia. Pretendia subverter um "realismo banal"; corolário dessa subversão é a representação da efemeridade moderna num tempo truncado, que demanda um tipo distinto de visão da modernidade: variável, efêmera e fragmentada, emblemática daquela hora histórica. "Que Degas tenha pensado como fotógrafo antes mesmo de fotografar nos intriga. Entretanto, refletir sobre o fato é essencial para esclarecer como o artista nos ensina a ver. Mais que qualquer outro pintor do século XIX, Degas compreendeu o que significa 'ver em termos fotográficos', o que não constitui atenção particular a detalhes. Degas, que colocava o desenho acima de tudo [...], era atraído pela precisão das fotografias que se alastravam ao seu redor. Artisticamente, no entanto, considerava abominável 'a colheita de dados' [la récolte] feita pela objetiva de vidro das câmeras escuras. Sua visão era seletiva: na contra-mão de uma representação eloquente nos termos tradicionais, subvertia 0 realismo banal por uma filosofia de mise en scène calculada. O teatro de Degas é sinônimo de pose." Cf. PARRY, E. Le théâtre photographique d'Edgar Degas. In DANIEL, M. [et alii]. Edgar Degas photographe. Paris: Bibliothèque National de France, 1999, p. 53.
} 
direta" nos aproximaria daquilo que "é", não do que "deveria ou poderia ser". Insiste, portanto, num tipo distinto de visão, monocular, na qual o olho é um ponto externo ao quadro que liga, por meio de retas convergentes, os pontos internos isolados do espaço a ser representado ${ }^{41}$. Evidentemente, a racionalização de tal lei, tomada não apenas como norma que expressa estados imutáveis mas como um valor no código de representação, torna-se puro anacronismo na Paris do século XIX, a hora histórica de Degas. Algoritmo da racionalidade monetária e da lógica burguesa contra a qual o artista da vida moderna se posicionava, não poderia jamais ser a estrutura basilar da representação de um espaço histórico, dinâmico, conflituoso, no qual o sujeito que vê é indissociável do objeto que é visto. Este espaço exige, como vimos, gesto célere, preênsil e resoluto. Um pintor como Degas compreenderá o desafio histórico e artístico que se lhe impõe e buscará uma nova configuração

\footnotetext{
${ }^{41}$ Naturalmente, a utilização da perspectiva (uma palavra latina que significa "ver através de") como conceito e técnica de representação do espaço para acesso ao que "é" via "observação direta" não deve ser tomada por seu valor de face. Primeiramente porque pressupõe que 0 observador utilize apenas um olho - e fixo, que jamais pisca - na contemplação da cena, estruturando-a matematicamente e, portanto, prescindindo por completo do espaço psicofisiológico. O componente racional e homogêneo que decorre desta aparente neutralidade semântica advém do fato de que seus elementos são pontos reunidos num espaço representado como infinito, que não passam de marcas de posição. Ausente a relação de hierarquia, ordem e subordinação imposta pela técnica a esses pontos, não possuem conteúdo autônomo ou real função. Com a utilização desta técnica, o espaço imaginário alastra-se por todo o quadro, e mesmo para além dele, "abrindo-se", (re)criando e abarcando todo o universo conhecido. Pretendendo-se um espaço purificado da contaminação subjetiva, a consolidação da visão monocular prioriza mormente o espaço da visão do indivíduo, por oposição àquele psicofisiológico, no qual visões que manifestem experiências ou modos de ver de natureza coletiva ainda eram possíveis no medievo. A construção do espaço perspéctico na alta renascença se desenrolará cada vez mais neste sentido, estribada na relação matemática do cálculo. $O$ microcosmo representado na tela "duplicará", assim, o macrocosmo invisível, recriado segundo leis "naturais", concebidas por deuses graduados em matemática (financeira!). Nascerá então um olho sujeito, acima da duração temporal, que se desprende do corpo, eclipsando-o; a imagem transformar-se-á em pura idéia e a aparência cederá lugar à "realidade". Esta concepção é expressão de um racionalismo limitado e limitador porque fundado na lógica interna da obra muito mais que na conformidade de seus elementos com a realidade externa. Daí a idéia de estado imutável, não de processo, subjacente à concepção perspéctica. A constância e homogeneidade da cena teatralizada denotará, na irrealizável re-estruturação de seus componentes, aumento no grau de atrofia do poder de imaginação para o espectador moderno, bem como a hostilidade da tradição que se constitui face a qualquer forma de representação que pretenda por em xeque a "janela" perspéctica, ou, se preferirmos, o "cofre" no qual o ato de ver fora cuidadosamente encerrado. Para detalhamento do assunto, ver ARGAN. G. C. História da arte italiana - volume II de Giotto a Leonardo. São Paulo: Cosac \& Naify, 2003.
} 
espacial, na adoção de um ponto de vista "fotográfico" para sua pintura, que possibilite ao observador uma recepção mais tátil da obra ${ }^{42}$.

"[Degas] recorre sem preconceitos ao auxílio da fotografia, que revela aspectos ou momentos do verdadeiro que escapam à vista; como a fotografia, a pintura deve ver e tornar visíveis coisas que o olho não vê e, principalmente, fornecer uma imagem instantânea onde a vista e a mente ainda não conseguiram separar a coisa que se move do espaço onde se move." 43

Encontramos em $O$ absinto (Figura 8), de 1876 um claro exemplo do olhar fotográfico que põe em xeque a utilização tradicional da perspectiva artificial e do universo por ela representado. Num café popular duas figuras do bas-fonds parisiense sentam-se diante de suas bebidas. A mulher (uma prostituta?), alcoolizada e absorta em seus devaneios, e o homem, o boêmio "aprisionado" no canto direito do quadro, comprimido entre a mesa e a parede, são vistos através de uma perspectiva enviesada, que inclui em grande parte da tela os tortuosos ângulos das mesas. Estes permitem que nós, os espectadores da cena que "ocupam" os assentos da mesa representada em primeiríssimo plano, frequentemos o ambiente como um "cliente" que possui um ponto de vista privilegiado: nossa posição na ou diante da tela - e as exigências formais que nos serão por ela feitas - não nos permitirá partilhar de semelhante inibição nos centros nervosos causados pela bebida, que atinge e entorpece as personagens de modo a enfraquecer (ou sonegar-lhes) qualquer possibilidade de "visão" (à época, o absinto era comumente conhecido como "fée verte", ou fada verde, graças a seus notórios efeitos alucinógenos). Assim, nosso olhar investiga a cena: percorre primeiramente "nossa" própria mesa, chega a uma superfície não

\footnotetext{
${ }^{42}$ A formulação do conceito de "recepção tátil", por oposição à "recepção ótica" (ou seja, a mera contemplação) é de Walter Benjamin. Cf. A obra de arte na era de sua reprodutibilidade técnica. In Obras escolhidas - magia e técnica, arte e política. op. cit.

${ }^{43}$ Cf. ARGAN, G. C. Arte moderna - do lluminismo aos movimentos contemporâneos. op. cit. p. 106.
} 
identificada que nos conecta à outra mesa um pouco mais ao fundo, na qual repousa uma garrafa da bebida alcoólica, elemento que nos vincula (mas por oposição!) às figuras humanas sentadas à mesa seguinte. $O$ espelho atrás do casal torna o ponto de fuga perspéctico incerto e fugidio, impedindo que o olhar do observador se esquive das personagens. Neste caso, a "nova" perspectiva é um elemento central para a recuperação da experiência da vida moderna pois, diferentemente da fórmula renascentista, explicita-se como ponto de vista construído. A utilização de determinados procedimentos oriundos da câmera fotográfica, a saber, o achatamento dos planos (como se o pintor utilizasse aqui uma lente tele-objetiva, que proporcionaria efeito semelhante) associado à decorrente montagem (fazendo, portanto, com que as mesas se aglomeram no quadro de modo quase "improvável") permitem a manipulação da realidade em tal nível que consentem ao artista a possibilidade de penetrar o âmago da realidade descrita para, somente assim, recuperá-la livre de manipulações. Num continuum entre pintor e fotógrafo, Degas parece encontrar-se num meio-termo: o pintor tem consciência de que o fragmento retratado - seu "fotograma" - deve ser visualmente recomposto de modo a revelar-nos, no mais alto grau permitido por uma forma de expressão artística não-reprodutível, o inconsciente ótico da cena ${ }^{44}$.

\footnotetext{
${ }^{44} \mathrm{O}$ argumento que proponho tem como base as reflexões de Walter Benjamin sobre as relações entre pintura e fotografia/cinema. Cf. A obra de arte na era de sua reprodutibilidade técnica. In Obras escolhidas - magia e técnica, arte e política. op. cit. Paul Valéry, em seu estudo sobre Degas publicado originalmente em 1935, explicita as relações do pintor com a fotografia, porém em chave distinta daquela aqui sugerida: para ele, o meio reprodutível parece ser uma ferramenta que, se devidamente utilizada pela pintura, permite desvendar as estruturas da vida moderna. O pintor deve estabelecer uma relação amistosa com os meios reprodutíveis, guardando, porém, sua devida distância para não macular a obra de arte: "[Degas] foi um dos que primeiro compreendeu o que a fotografia poderia ensinar ao pintor e, ao mesmo tempo, o que o pintor deveria abster-se de tomar emprestado à fotografia. [...] [Degas] pretendia distinguir o que denominava mise en place, ou seja, a representação convencional dos objetos, do que denominava "desenho" [dessin], a saber, a alteração por que passa esta representação exata, por exemplo, pela utilização da câmera clara [chambre claire]. [...] A câmera clara, que entendo ser o melhor meio para definir mise en place, nos permitiria iniciar o trabalho de qualquer ponto, dispensando-nos de tomarmos uma visão do todo, dos esforços de encontrar relações entre linhas ou superfícies, etc., de não atuarmos sobre a coisa vista para somente então transformála em coisa vivida, ou seja, num ato pessoal." Cf. VALÉRY, P. Degas Danse Dessin. Poitiers: Gallimard, 2003, pp. 58, 206- 207.
} 
A tela $\mathrm{Na}$ bolsa de valores (Figura 9), de 1879 também apresenta uma configuração fotográfica da cena nos termos acima descritos. Em primeiro plano, a bem vestida e elegante figura de um homem de negócios em frente ao edifício da bolsa de valores de Paris, o banqueiro, especulador e patrono das artes Ernest May, retratado de perfil e quase de corpo inteiro, imóvel, posicionado no centro da pintura. É o elemento da cena que possui maior riqueza de detalhes: a cartola delineada, a pálpebra salientada atrás do pince-nez, o nariz angular, os lábios protuberantes, e, não menos importante, a orelha bem definida, salientada por pequenas pinceladas que revelam curvas, ângulos e cores. Ao seu redor, outros especuladores, seus pares: à direita, um pequeno grupo de homens, um dos quais - apenas parcialmente representado na tela - parece oferecer-lhe um papel, que May lê com aparente ar de superioridade, porém de evidente interesse. Outro homem de negócios, como o anterior meramente esboçado, passa rapidamente pela cena: sua figura, apenas sugerida, logo "sai" do campo de visão, deixando apenas seu rastro (como as figuras que, ao se moverem rápido demais, não deixavam, nas antigas fotografias, senão uma "impressão"; suas trajetórias registravam-se como vultos ou borrões). À esquerda, outro homem sussurra algo no ouvido do banqueiro, cuja orelha em destaque ouve atentamente o que lhe é segredado. A mão direita nos ombros de May, a cabeça levemente inclinada para frente, a face oculta sob o negro da cartola - uma das cores dominantes do quadro - indicam a proximidade da (ilícita) relação entre os dois. A narrativa do quadro não deixa dúvidas quanto à natureza das operações financeiras realizadas: em meio às rápidas (e inebriantes!) mudanças que ocorrem na cena, May, com ar altivo, aparentemente nonchalant, conspira, faz alianças e considera toda e qualquer inside information para especular com avidez. Esta pintura, acredito, explicita a gênese de procedimentos inerentes à fotografia e ao cinema: como expressão artística essencialmente urbana, prevê - e instaura - o "antes" e o "depois" da cena. A eleição do "instante decisivo" (posteriormente tão identificado com a fotografia na figura de Henri CartierBresson ${ }^{45}$ ) proporciona ao observador do quadro - outro financista da bolsa de

${ }^{45}$ Cf. BRESSON, H.-C. The Decisive Moment. In The Mind's Eye - Writings on Photography 
valores? outro especulador? certamente um frequentador (do sexo masculino) deste ambiente - uma síntese do todo no fragmento, primando, como exigiam Diderot e Baudelaire, pela legibilidade da cena e pela concentração de sua significação. Em Degas, este olhar realista e não-aristocrático explicita-se cada vez mais como demanda histórica (exigida, como vimos, inclusive pela própria pintura).

As transações ilegítimas são rapidamente consumadas, mesmo que ainda não oficializadas no interior do edifício da bolsa. Um segundo plano muito próximo, quase comprimido ao primeiro, como se registrado por uma tele-objetiva, encurta a profundidade de campo, sugere montagem e impele o observador a aproximar-se dessa cena com essas personagens, forçando-o a estabelecer relações entre os indivíduos ali representados ${ }^{46}$. A enunciação do espírito vigente, atomização, ligações momentâneas de interesse, enfim, o "vale-tudo" generalizado, é ratificado pelas únicas possibilidades de fuga que encontra o olhar: a cartola de outro especulador que parece adentrar o edifício ou as diminutas figuras de outros dois homens de negócios do outro lado da pilastra do prédio. Um deles tem seu corpo apenas sugerido, parcialmente representado, aludindo, com o mesmo "corte fotográfico" presente à direita da pintura, à continuação da cena no extra-quadro. Os dois homens, comprimidos entre a pilastra e a borda da tela pela mesma perspectiva que comprimia o casal de $O$ absinto (seu pendant, ou mais precisamente, seu "negativo fotográfico"), encontram-se tão próximos e íntimos, narizes colados e braços nos ombros, que mais parecem formar um casal de furtivos amantes. Como aqueles que circulam clandestinamente no segundo plano de No café-concerto, a canção do cão (1875-77), tela que retrata a cantora Thérésa, na posição de cão fiel pedindo comida, executando seu número musical. Em ambas as obras, dinheiro e

and Photographers. Millerton, NY: Aperture, 1999.

${ }^{46} \mathrm{O}$ encurtamento da perspectiva e a idéia de montagem não eram procedimentos alheios às produções gráficas e fotográficas de Degas, em monotipias como "A lareira", de 1877-79 ou nas fotografias como "Auto-retrato com 'A mulher que chora', de Bartholomé" (sem data) ou "Mathilde e Jeanne Niaudet, Daniel Halévy e Henriette Taschereau, Ludovic et Élie Halévy", montagem fotográfica sem data que prenuncia as linguagens desenvolvidas pelas vanguardas europeias do século XX). Cf. DANIEL, M. [et alii]. Edgar Degas photographe. op. cit. 
prostituição encontram-se intimamente relacionados. Em Na Bolsa..., no entanto, Degas explicita, em outros termos, o que sugere No café...:

"[...] o espaço é abarrotado de detalhes significantes, muitos deles familiares a essa altura: cartolas e chapéus de puta no primeiro plano, músicos desalinhados, baterias de luzes e folhagens, figurantes inquietas. Mas o cerne da questão é sempre Thérésa: o movimento de seu polegar para trás entre os versos de um refrão, o gesto amplo de chamar a platéia para dentro da canção, o cabelo preso num coque, o rosto de pugilista. Era assim que ela dominava as distrações à sua volta e as tornava parte do número. Ela flutuava sobre as luzes, os perfis e chapéus elegantes, e esculpia um espaço para si própria em oposição a eles."47

Ernest May é a versão burguesa da cantora de cabaré barato: as operações financeiras consumadas na bolsa de valores são o seu show. O banqueiro e mecenas organiza a cena, orquestrando-a em seu favor; veta a participação de todos que não servem a seus interesses (inclusive os espectadores do quadro, que tomam parte dos acontecimentos apenas em certa medida, pois jamais "escutam" os segredos que chegam aos ouvidos de May), e esculpe, não apenas para si mas para todos à sua volta, um espaço abstrato, ou abstratizante, corolário da abstração do próprio Capital, o verdadeiro astro do evento que tem lugar num palco bastante preciso, a bolsa de valores de Paris. Neste espetáculo, se há amor, o único possível é aquele ao dinheiro, aos ganhos ilícitos, à conspiração financeira - o amor à classe. Ou talvez nem mesmo a esta: o cenário do número de May é certamente o da classe, mas também o da fratura de posições ligadas à traição da classe. No quadro de Degas o burguês não tem, assim como a prostituta, qualquer tipo de fidelidade,

${ }^{47}$ Cf. CLARK, T. J. A pintura da vida moderna - Paris na arte de Manet e de seus seguidores. op. cit. p. 298. 
nem mesmo aos membros de seu próprio grupo, quando se trata de atingir benefícios (ou prazeres) financeiros ${ }^{48}$ (pensemos nas azedas caricaturas de Daumier). O ponto de vista privilegiado do observador (novamente) desnuda as aparências burguesas para si e para o próprio burguês, revelando todas as facetas de suas traições. Na bolsa... expõe formalmente a concretude abstrata da lógica dessas relações ao dissolvê-las.

Retornemos às categorias do "espetáculo" e da "classe" como balizas do processo de compreensão e representação visual da experiência moderna na metrópole. Se, como pretendi demonstrar, Courbet, Millet e Degas, cumprem, em graus distintos, algumas das demandas baudelarianas feitas em $O$ pintor da vida moderna, será, contudo, Manet quem melhor compreenderá as exigências do poeta e crítico de arte, fazendo do espetáculo e da classe os estribos para a expansão dos horizontes da pintura - como prática urbana, crítica e reflexiva com tal índice de radicalização que consumará a dissolução das fronteiras

\footnotetext{
${ }^{48}$ Georg Simmel explicita os paralelos entre dinheiro e prostituição: "Apenas o dinheiro, que não implica qualquer compromisso, e que a princípio está sempre disponível e é muito bem-vindo, é o equivalente apropriado ao intenso e fugaz apetite sexual que é saciado pela prostituição. $O$ dinheiro não é jamais um mediador adequado das relações pessoais, tais como relações genuinamente amorosas, não importa quão abruptamente elas sejam rompidas, que tencionam ser permanentes e baseadas na sinceridade e no compromisso. O dinheiro é que melhor serve, em termos objetivos e simbólicos, à satisfação venal que rejeita qualquer relação que perdure para além do impulso sexual momentâneo, pois é completamente desvinculada da pessoa e, desde o princípio, descontinua maiores consequências. Quem paga com dinheiro se desvincula de qualquer objeto de modo tão definitivo quanto o cliente que paga uma prostituta pela satisfação. Uma vez que na prostituição a relação entre os sexos é especificamente confinada ao ato sexual, ela é reduzida a seu puro conteúdo genérico. Ela consiste no que todo exemplar da espécie é capaz de sentir e fazer. É uma relação na qual as personalidades mais contrastantes são iguais e diferenças individuais são eliminadas. Portanto, a contrapartida econômica deste tipo de relação é o dinheiro, que também, transcendendo todas as distinções individuais, representa o que é comum a todos os valores. Por essa razão experimentamos na sua natureza algo da natureza da prostituição. A indiferença com que se desprende das pessoas, pois não se liga verdadeiramente a nenhuma, a eficácia que tem por ser puro meio, que exclui qualquer vínculo afetivo - tudo impõe essa sua analogia sinistra com a prostituição." Cf. SIMMEL, G. The Philosophy of Money. Londres: Routledge and Kegan Paul Ltd., 2003, pp. $376-377$.
} 
tradicionais da pintura às quais sua arte estava circunscrita ${ }^{49}$, ultrapassando mesmo as solicitações do amigo sobre a experiência da modernité: Manet efetuará "progressivamente a determinação da mercadoria e da troca como fundamentos do processo maior em curso."50 No epicentro deste processo na Paris capital do século XIX, a capital da mercadoria ou a capital do Capital, codificará em termos visuais as relações entre espetáculo urbano, mudanças econômicas, substituição de modos de vida e os correlatos deslocamentos dos contextos de sociabilidade, desacordos com laços antigos e o isolamento e desamparo social decorrentes do processo de modernização pelo qual passava a cidade, seus arredores e sua população. Trata-se, em outras palavras, da representação da verdade estrutural de um tempo no qual:

"a burguesia está em plena posse de seu poder e tem absoluta consciência disso. A aristocracia desapareceu da cena dos eventos históricos e leva uma existência puramente privada. A vitória da classe média é indubitável e incontestável. É verdade que os vencedores formam uma classe capitalista inteiramente conservadora e não-liberal, adotando as formas e os métodos administrativos da antiga aristocracia, muitas vezes sem a menor alteração; mas é uma classe que, em seu modo de viver e de pensar, apresenta uma postura absolutamente não aristocrática e não tradicionalista. [...] Logo, porém, que se concretiza a emancipação da classe média, tem início a luta da classe trabalhadora por seus direitos. E esse é o segundo dos

\footnotetext{
${ }^{49}$ Baudelaire, em carta escrita ao amigo pintor, constata a caducidade da pintura tradicional e o reconhece como marco na implosão do conceito tradicional de pintura: "você é apenas o primeiro na decrepitude de sua arte." "Decrepitude" em Manet equivale à superação do trabalho artesanal em favor da nova divisão do trabalho, pautada pela excentricidade irredutível entre trabalho intelectual e braçal no capitalismo desenvolvido. A esse respeito, ver MARTINS, L. R. Pintura e trabalho: trabalho intelectual e trabalho corporal na pintura de Cézanne, Van Gogh e predecessores. op. cit. e BAUDELAIRE, C. À Edouard Manet [Bruxelles] jeudi 11 mai 1865. In Au-delà du Romantisme - Écrits sur l'art. Paris: Flammarion, 1998, pp. $301-302$.

${ }^{50}$ Cf. MARTINS, L. R. Manet - uma mulher de negócios, um almoço no parque e um bar. op. cit. pp. $36-37$.
} 
movimentos decisivamente importantes que decorrem da Revolução e Monarquia de Julho. Até então, as lutas de classe do proletariado tinham-se fundido com as da classe média, e fora principalmente pelas aspirações políticas das classes médias que a classe trabalhadora havia lutado. A evolução dos acontecimentos depois de 1830 abriu-lhe pela primeira vez os olhos e forneceu-lhe a prova de que, ao lutar por seus direitos, a classe trabalhadora não podia fiar-se em qualquer outra classe. Simultaneamente com o despertar da consciência de classe do proletariado, a teoria socialista adquire sua primeira forma mais ou menos concreta, e surge também, nesse momento, o programa de um movimento ativista e artístico que, no tocante a radicalismo e consciência, suplanta todos os movimentos prévios de natureza semelhante. A art pour l'art passa por sua primeira crise e tem daí em diante de lutar não só contra o idealismo dos classicistas mas também contra o utilitarismo da arte 'social' e 'burguesa”". ${ }^{51}$

Como Manet (segundo o próprio Degas) utiliza seu "instinto estratégico da ação pictórica", "chegando ao 'supremo' de sua arte"52, para confrontar o idealismo dos classicistas, e o utilitarismo da arte burguesa? Como expandiu as fronteiras da própria produção moderna de caráter progressista contemporânea à sua aos limites do possível, expondo seus alcances e limites? E, não menos importante, quais os meios cifrados em sua obra que apontam para novas possibilidades - e demandas - técnicas e artísticas?

Pensemos primeiramente no caráter "ilusionista" da produção de Manet. Ao analisar a pintura Barqueiros em Argenteuil (Figura 10), de 1874, Clark assinala

\footnotetext{
${ }^{51}$ HAUSER, A. História social da arte e da literatura. op.cit. pp. $728-729$.

${ }^{52}$ Cf. VALÉRY, P. Degas Danse Dessin. op. cit. p. 61.
} 
uma série de elementos constituintes de seu ilusionismo. De início, chamou atenção para a planaridade do quadro: o rio azul, espesso e opaco, pintado como uma parede atrás das personagens e o chapéu da mulher, superfície em primeiro plano que se "cola" ao muro branco no fundo da tela. Apontou, neste âmbito, as "incongruências" na pintura, seu caráter fragmentário, e como este no limite, a própria técnica - parece chamar atenção para si, ao discorrer sobre a utilização da cor:

"Signos, coisas, formas e modos de tratamento não se encaixam aqui. A tinta não constrói continuidades, nem engendra transições para o olho; ela reforça as distinções e disparidades, muda completamente ao longo de um contorno, insiste na rigidez de uma pose ou na aspereza do azul contra o amarelo. Essa é a linguagem geral do quadro - essa deselegância de interseção, essa dissonância de cor."53

Identificou rimas visuais e a representação de falsos equivalentes, espécie de "tropos visuais" que relacionam aparência e engano, ou, em âmbito totalizante, aparência e essência:

"Entre as figuras, delineada contra o céu, está uma distante chaminé de fábrica. Abaixo dela, um reflexo se estende pela água, cinza e branco a princípio, abrindo lentamente para as ondulações do rio e reaparecendo mais abaixo, um pouco mais disperso e manchado de amarelo, antes de a superfície da água afinal se interromper. Mas na verdade essas marcas não são um reflexo: são uma formação em linha de falsos equivalentes - dois pedaços de corda pendendo da ponta de uma vela enrolada, e quatro pequenas flores amarelas apartando-se da fita do chapéu da mulher. São uma espécie

${ }^{53}$ Cf. CLARK, T. J. op. cit. p. 232. 
de piada [...] sobre a falsa equivalência; sobre coisas que parecem se relacionar e que depois revelam o engano; sobre a ilusão, sobre a diferença entre a ilusão e a falsidade."54

Finalmente, explicita o aspecto fotográfico da imagem: a pose artificial das personagens e sua relação com o esvaziamento das subjetividades das figuras humanas:

\begin{abstract}
"As pessoas no quadro estão posando, talvez possamos colocar dessa maneira - não como os modelos dos artistas, mas como fariam para uma fotografia, e de fato isso ocorreria mais tarde em locais exatamente como aquele. O rosto fica vazio, o corpo sem jeito, elas esquecem como parecer alegres ou mesmo sérias. O rosto da mulher, em especial, é trabalhado e retrabalhado até um ponto de obliteração; é manchado, sombreado e abreviado, desprovido de cabelos, semelhante a uma boneca, animado mas opaco. Os olhos contemplam o que está à frente, nivelados, sob a aba do chapéu, a boca se entreabre, os brincos e o laço do pescoço estão arrumados com esmero. A mulher resiste às descrições dos críticos: ela não é propriamente vulgar, não é tampouco "ennuyée" [aborrecida], nem sequer mal-humorada." 55
\end{abstract}

A escolha do tema em Barqueiros... já é um índice significativo da aproximação entre Baudelaire, Manet e a experiência da modernidade. O cenário é a banlieue parisiense, e uma em particular: a vista identificável de Argenteuil, lugar de reputação na imaginação popular pelo crescente número de fábricas e pela ameaça à ordem, numa combinação de liberdade irrestrita, alto grau de criminalidade, abundância de bebidas, prostituição, proliferação de doenças e,

\footnotetext{
${ }^{54}$ Cf. CLARK, T. J. op. cit. p. 233.

${ }^{55}$ Cf. CLARK, T. J. op. cit. pp. $235-237$.
} 
não menos perigoso, trabalhadores com fortes convicções sobre seus direitos e seu crescente nível de organização. Argenteuil tornava-se, assim, um local (ou modelo) cada vez mais indesejável, uma vez que seus "maus elementos", líderes socialistas em sua maioria, paulatinamente substituíam em número os pedintes e os vagabundos, num processo que acontecia simultaneamente em outras regiões do entorno de Paris, Corbeil por exemplo, mas também no Midi, onde as idéias e escritos dos companheiros parisienses eram largamente difundidas para além do olhar policial.

A pintura trata da modernização dessa Argenteuil via industrialização, bem como dos hábitos correlatos de consumo e divertimento daquela classe média que deixava a capital em suas horas de folga para, endomingada, passar momentos de diversão numa "meia-Paris", nem campo nem cidade, local intermediário entre uma coisa e outra. Manet reúne classe, consumo, campo e indústria insistindo em suas "correspondências". A escala da pintura não é menos importante: um óleo sobre tela de tais dimensões, $148 \mathrm{~cm} \times 115 \mathrm{~cm}$, seria adequado para representações de cunho histórico, conforme prescrições acadêmicas; era certamente impróprio para retratar uma cena considerada como um gênero inferior. Das escolhas feitas pelo pintor, conclui-se que Manet eleva o "gênero inferior" e seu assunto à categoria de pintura histórica ou, se preferirmos, estabelece relações entre o sujeito da pintura e sua História. Para fazê-lo, o pintor evade-se do acabado na pintura (o morceau fini de Ingres, Janmot ou Saint-Jean, os "ouvriers en peintures", segundo Baudelaire), elevando o ébauche à categoria de morceau fait. $O$ que isto significa?

Em pintura, a prática acadêmica tradicional era a execução de uma série de estudos antes da produção final do quadro: o croquis (o esboço preparatório da composição), o esquisse ou esquisse peinte (o esboço pintado da composição inicialmente concebida para o quadro, resultado da inspiração espontânea advinda da imaginação do artista) e o étude (um rápido estudo que se concentrava na harmonia da composição e que procedia da observação direta 
da natureza). Associado à idéia de ordenação intelectual dos elementos presentes na obra, o esquisse trazia consigo a conotação de "invenção". Já o étude era considerado menos "criativo" e mais uma descoberta ou achado "passivo" do pintor. O ébauche, por sua vez, era o esboço pintado de maneira rápida e esquemática, em tons terrosos e com uma técnica de esfregação com panos que dava uma vaga indicação da modelagem da composição final. Todos estes sketches traziam consigo a idéia do inacabado e da pincelada livre e pouco definida. Estes não eram, contudo, os únicos aspectos relevantes no que tange o "acabado" ou "não-acabado" na tela. A composição do quadro muitas vezes revelava que uma pintura aparentemente "não-acabada" era, na verdade, produto de cuidadosa observação das regras prescritas pela academia. A articulação geral de sua composição, sobretudo no que diz respeito à utilização de modos de representação da luz e cor, neste caso com sutis gradações de luz e sombra (chiaroscuro), e sua consequente "costura" ou uniformidade geral atribuída aos elementos da cena e à atmosfera geral do quadro, cria efeitos ilusionísticos de transição contínua e harmônica, produto da rígida e deliberada hierarquia que estrutura a representação clássica de paisagens ou retratos. Se as pinceladas livres evocam, por um lado, espontaneidade e instantaneidade, por outro, a rígida composição a nega com a mesma veemência. Esta dicotomia era marca presente, por exemplo, na obra de Thomas Couture, mestre e professor de Manet.

Considerado pintor tecnicamente progressista por estimular desvios técnicos em relação à pintura tradicional, Couture enfatizava a importância dos estágios iniciais da representação, bem como a variedade de temas, incluindo cenas de rua. No entanto, seu discurso diferia substancialmente de sua prática artística. Pequeno Gilles, de 1878, é exemplo da dicotomia técnica entre, por um lado, espontaneidade e impulso da pincelada e, por outro, estruturação nos moldes acadêmicos do padrão de iluminação, o que conferia à tela um enfoque ainda muito convencional. Seu método de ensino desprivilegiava ainda o estudo sistemático da tradição e a formação e treinamento acadêmicos: "em todas as 
circunstâncias, a expressão ingênua e sincera, desprovida de toda erudição, é preferível à expressão letrada". A partir da experiência de Couture, Manet depura a técnica aprendida, expandindo suas fronteiras e possibilidades: encampa temas "não-acadêmicos", substitui os tons terrosos característicos do ébauche por "cores locais", elevando-o à condição de superfície acabada e operando a síntese faltosa no conjunto da obra de seu mestre entre espontaneidade, instantaneidade e estruturação da composição ${ }^{56}$. Como?

A representação de planos achatados com abrupto encurtamento da perspectiva desfere o golpe de misericórdia contra a moribunda harmonia clássica da representação do espaço como a priori ideal, harmônico, dado e cognoscível. O tratamento das vestes da mulher, um amontoado de cores e pinceladas justapostas, a "parede sólida" de um Sena azul e poluído, o chapéu da dama colado no muro ao longe, o casco dos barcos, tudo em Barqueiros... parece resistir à fusão tonal, à transição espontânea, à naturalização do significado, enfim, à contribuição para o fluxo tradicional da narrativa. A superficialidade da "sensação" visual motiva a interrupção do discurso e os saltos na história. $\mathrm{Na}$ imagem, explicitamente artificial, predomina a justaposição de objetos, planos e cores. Em suma, os artifícios da composição desaparecem por completo e o truque (a repetição que celebra a si mesma como forma autônoma) abre espaço para a técnica (a ampliação e o adensamento expressivo dos recursos técnicos disponíveis, com a função cognitiva de mapear o estado da situação, expondo ou desmascarando as contradições sócio-históricas de seu tempo): não há lugar para a perspectiva euclidiana ou o chiaroscuro caravaggesco nem para a tradição artesanal que valorizava maestria e soluções únicas; a representação da cor não mais obedece às diretivas naturais. É, ao contrário, expressão do intelecto e dos sistemas de significação elaborados pelo homem. Manet não pinta a realidade que "vê" (como argumentaria Zola, enfatizando mais o sujeito

\footnotetext{
${ }^{56}$ A esse respeito, ver FRASCINA, F. [et alii]. Modernidade e modernismo - a pintura francesa no século XIX. São Paulo: Cosac \& Naify Edições, 1998. e SHIFF, R. Cézanne and the End of Impressionism - A Study of the Theory, Technique, and Critical Evaluation of Modern Art. Chicago e Londres: The University of Chicago Press, 1986.
} 
que vê do que o objeto que é visto ou, por outra, escrutinado ${ }^{57}$ ) mas aquela que conhece ou vivencia em termos políticos: o amarelo do barco que se choca contra o azul do rio, em encontrões recíprocos, sem qualquer transição ou "sutileza", é a regra de sua produção. A substância física dos materiais na obra, as coisas pintadas como "coisas" e a tinta que se dá a ver como "tinta", expõe a "gaucherie" do pintor e confronta o observador, que deve fazer face à realidade, não uma em abstrato, mas àquela equivalente à consciência que dela se deriva e, para tanto, trava com a obra um embate intelectual e corporal que pretende desorientar todo senso pictórico normatizado. O caráter exigente desta obra não apenas demanda um espectador à sua altura mas eleva seu gosto: não mais fascinado pela maestria do truque bem executado, tende a abandonar o tipo de participação (tradicional) que lhe é destinada na fruição da arte convencional, a saber, aquela que também o concebe como mercadoria.

"É preciso pensar o espaço concretamente, a partir de relações entre massas físicas, e não como algo dado e apriorístico. Se as relações forem repensadas cromaticamente, a concretude das coisas pedirá cores opacas e espessas, dispostas impenetravelmente umas frente às outras. Com efeito, nas telas de Manet, as cores parecem se dispor às cotoveladas como numa obra gráfica e pouco sutil, com meios industriais. A pintura opaca, espessa e sem brilho já fora feita por Courbet e pelo pintor bissexto Daumier - sem falar nas telas de David, do período da Revolução, e de Chardin (1699-1779), antes ainda. Mas nas pinturas de Manet o passo se faz mais completo porque interage com outras medidas estruturais. Consolida-se não como achado ou traço de estilo, mas como parte estrutural de um partido materialista, ponto de um modo ou método. As cores em Manet referem-se, pois, no plano do sujeito, à disparidade das

${ }^{57}$ Cf. ZOLA, É. Écrits sur l'art. Paris: Gallimard, 1991. 
sensações físicas, e não à unidade dos sentimentos da alma. [...] Como responder ao repto de uma tal cena urbana, senão por uma invenção pictórica à altura da novidade?"58

A "invenção pictórica" de Manet está, pois, em chamar deliberadamente atenção para a forma. Se cabe aqui falar em uma "técnica de originalidade" 59 , esta seria, como vimos, seu ponto ou "método" de trabalho, que ao partir da observação direta da natureza e da clara intenção de acarear a tradição que o precede com os novos modos de representação que forjava, ambiciona dar conta da experiência da modernidade, introduzindo, no seio da pintura, "distorções" ou "desvios", sem os quais a verdade estrutural de seu tempo continuaria camuflada. Nesta imagem, que para transmitir a idéia de espontaneidade e instantaneidade faz uso da artificialidade altamente calculada, toda conexão "natural" é, como pretendi demonstrar, implausível e demanda do espectador questionamento e ativação política ${ }^{60}$. O "corte fotográfico" escolhido pelo pintor corrobora a idéia das relações entre os modos de representação na pintura e a sua correlata experiência no extra-quadro: o barco, o mastro, a corda, as velas, o banco e o pés das personagens estão todos "cortados" pelo "instantâneo fotográfico", o snapshot feito pelo pintor. Sua técnica, opera, assim, como uma metáfora: transfere significado do "original" para a representação ao mesmo

${ }^{58}$ Cf. MARTINS, L. R. Manet - uma mulher de negócios, um almoço no parque e um bar. op. cit. pp. $39-40$.

${ }^{59}$ O termo é cunhado por Shiff para descrever e avaliar a técnica de Cézanne. Cf. SHIFF, R. Cézanne and the End of Impressionism - A Study of the Theory, Technique, and Critical Evaluation of Modern Art. op. cit.

${ }^{60} \mathrm{O}$ caso da recepção da tela pela crítica da época demonstra o grau de ativação política do espectador imposto pela pintura de Manet. Os críticos reacionários defendiam arduamente a incapacidade do pintor de manejar certos códigos, todos aqueles prescritos pela norma acadêmica. $O$ que Ihes parecia insuportável é que sua pintura, como aquela de Courbet, exigia que tocassem em certos assuntos, impróprios para a arte tradicional e não tratar de tais assuntos quando se avalia a (ausência de) qualidade de uma tela do pintor é uma opção que simplesmente não está disponível. Mais que mau gosto ou inaptidão artística, as pinturas revelavam aos críticos que suas objeções, aparentemente estéticas, eram de fato de ordem política. "Manet é apenas um pintor e um pintor de fragmentos - desprovido de idéias, de imaginação, de emoção, de poesia ou de habilidade artística. Ele é incapaz de compor um quadro... Só um técnico pode julgar e apreciar o quadro"; "Monsieur Manet dedica-se deliberadamente a escolher os locais mais sem graça, os tipos mais grosseiros." Cf. FRASCINA, F. [et alii]. Modernidade e modernismo - a pintura francesa no século XIX. op. cit. pp. 84 85 e p. 113. 
tempo que transforma este original, dando a ele um novo contexto representacional. A originalidade de sua "cópia" reside, portanto, no fato de ser um meio para um fim.

A isto se liga a pose fotográfica identificada por Clark, procedimento típico na obra de Manet. As figuras que posam para esta "câmera" são constantemente representadas com certa carga de inexpressividade, de ausência de determinação, de estados de incerteza ou de dissociação. Como em Barqueiros..., seus olhares esvaziados dificilmente se encontram (pensemos também em $O$ balcão, de 1868-69 ou, no limite do esvaziamento do olhar, que nem mesmo se dá a ver, em Berthe Morisot com um leque, de 1872). As personagens, mesmo quando em grupo, parecem saberem-se sós, recolhidas a estados íntimos e incertos. "Manet se faz o pintor do desencanto de si ou do esvaziamento do eu como fonte espontânea ou princípio de autenticidade das ações." 61 A partir da inexpressividade de suas personagens, resultado da massificação em franca marcha, o pintor revela formalmente o caráter permutável das figuras, que, como mercadorias, têm valor e que participam do processo geral da circulação do capital, como máscaras incessantemente intercambiáveis (Nana, 1877; Um bar no Folies-Bergère, 1881-82). Se há fantasmagoria nas cenas, esta é sua gênese:

"Na Paris das grandes avenidas e dos parques, das multidões e das vitrinas, das feiras internacionais e dos cafés-concerto, todos vêm e vão, orbitam em torno dos bens, estes também em movimento incessante. Desaparecem os bairros populares e as ruas dos artesãos. Não se trabalha onde se vive. Na cidade-mercado, capital protótipo das atuais cidadesshopping, nada tem raiz, tudo gira e se permuta. Então tudo é possível... As situações e relações advêm especulativamente,

\footnotetext{
${ }^{61}$ Cf. MARTINS, L. R. Manet - uma mulher de negócios, um almoço no parque e um bar. op. cit. pp. 51.
} 
como relação entre termos descontínuos, o que faculta ao artista, também, fazer qualquer montagem. Liberdade deste teor era encontrada nos dioramas e ateliês fotográficos, onde se podia posar dentro de exóticos cenários. Logo, não só os retratos e as cenas de Paris, por Manet, advêm da circulação intensa, que tornou flexíveis as barreiras de casta, como também a sua pintura explícita de ateliê, os "espanholismos", as cenas típicas montadas, dela derivam." ${ }^{.62}$

O velho músico (Figura 11), de 1862, uma das composições mais ambiciosas de Manet, já havia sistematizado diversas das questões acima e expandido os horizontes artísticos que pretendiam examinar os efeitos do processo de modernização de Paris. Como Barqueiros..., suas dimensões, $187 \mathrm{~cm} \times 248 \mathrm{~cm}$, revelam-se inapropriadas para uma pintura de gênero menor. Nela estão representadas várias das personagens tipicamente baudelairianas, parte do refugo da cidade, numa paisagem campestre não identificável e de aspecto claramente onírico (um eufemismo para "absurdo"): crianças indigentes, boêmios, ciganos, um boneco de ventríloquo, um músico violinista ambulante, um trapeiro ou representante empobrecido da classe média, além da figura do Judeu Errante. Embora encontrem-se "juntas", não existe qualquer relação aparente entre as personagens. Elas mal reconhecem a existência umas das outras; dispõem-se num primeiro plano lado a lado, figuras isoladas e alheias, como se expostas num palco, vitrine ou, no limite, em telas distintas. O músico, à exceção dos outros, é a única personagem cujo olhar parece expressar algo concreto: olha para fora da tela, encara o observador e tenta comunicar-se. Como e o quê?

Pensemos inicialmente nas referências de Manet para executar a pintura: a criança menor em primeiro plano é empréstimo da gravura (de um quadro

${ }^{62}$ Cf. MARTINS, L. R. Manet - uma mulher de negócios, um almoço no parque e um bar. op. cit. p. 54. 
exposto no Salão de 1861) A criança roubada, de Henri Guillaume Schlesinger, que apareceu na revista Le Magasin Pittoresque de 1861. Manet deve ter tido acesso a outras gravuras que circulavam na cidade para representar as figuras infantis em seu quadro, como La Béarnaise, extraída da série Les Français peints par eux-mêmes: encyclopédie morale du XIXe siècle, de 1841. O boneco de ventríloquo nos lembra Le Gilles, de 1721, de Watteau (e, remotamente, o Petit Gilles de Couture). O músico é o cigano Jean Lagrène, figura conhecida da periferia de Paris, mais especificamente de La Petite Pologne, região onde o quadro teria sido originalmente concebido ${ }^{63}$. Lagrène é representado a partir de algumas referências pictóricas: Filósofo sentado, de 1860, um estudo do próprio Manet feito no museu do Louvre, A refeição dos camponeses, de 1640, de Louis Le Nain, O flautista da aldeia, de 1642, de Antoine Le Nain e Os bêbados, de 1629, de Velázquez. O trapeiro ou burguês empobrecido é referência à tela $O$ bebedor de absinto, de 1858-59, do próprio Manet, por sua vez executada a partir de gravuras populares como Arranjo familiar boêmio, 1859-60, de Paul Gavarni, O trapeiro, 1841, de Charles-Joseph Traviès (extraída de Les Français peints par eux-mêmes) ou $O$ vendedor de roupas velhas, de Albert Bertall. $O$ Judeu Errante era tema comum de cartazes, livros e canções populares (um motivo especial em Courbet - por exemplo Bonjour, Monsieur Courbet, de 1854 - certamente uma referência para a execução desta pintura - mas pensemos também em Enterro em Ornans, de 1849 - 50, e no Baudelaire de Os sete velhos, de As Flores do Mal, de 1861) 64.

Manet opera uma "cirurgia estética" na imagística conhecida: mescla uma diversidade de códigos, dos eruditos aos populares, dos canônicos e originais

\footnotetext{
${ }^{63}$ Manet vivia e trabalhava em Batignolles, área próxima à Petite Pologne, hoje correspondente à extensão entre a Gare St. Lazare e o cemitério de Montmartre. Esta região seria modernizada e incorporada ao perímetro urbano da cidade por Haussmann na década de 1860.

${ }^{64}$ As referências às influências de Manet para a execução de "O velho músico" encontram-se em FRASCINA, F. [et alii]. Modernidade e modernismo - a pintura francesa no século XIX. op. cit. e CACHIN, F. Manet - “J'ai fait ce que j'ai vu”. Paris: Découvertes Gallimard et Réunion des Musées Nationaux, 1994. Para outras referências às gravuras populares que circulavam na França nesta época e que provavelmente influenciaram Manet, ver DIXMIER, M. [et alii]. Quand le crayon attaque - images satiriques et opinion publique en France 1814 - 1918. Paris: Éditions Autrement, 2007.
} 
àqueles mais corriqueiros e banais para, a partir de uma série de citações, ou citações de citações, representar o processo que gera a escória da sociedade moderna e compreendê-lo também nos termos visuais. De par com a atmosfera onírica do quadro, não obedece, como o sonho que pretende interpretar, qualquer distinção hierárquica ou convencional para tecer sua narrativa, citando e recuperando citações, como a própria estruturação do sonho, que se serve dos resquícios diurnos aos traumas da origem. Assim, e na esteira dos meios fotográficos, já desconsiderara a hierarquia na representação de pessoas e objetos em O tocador de guitarra, de 1860 e A cantora de rua, de 1862, mas aqui explicita sua desconsideração também pela hierarquia de materiais da tradição: um Gavarni pode estar ao lado - e ser utilizado como material - de um Daumier, desde que contribua para a narrativa e para o resultado final da tese que pretende ser demonstrada. Noutros termos, Manet incorpora, como material, as diversas fontes das quais se servirá para desenvolvimento de seu teorema: gravuras populares cujos retratos dos destituídos eram poéticos ou adocicados (Gavarni), caricaturas ácidas e politicamente incisivas (Daumier), fotografias (possivelmente do próprio Lagrène) e a experiência visual e cognitiva que o novo meio propiciava, pinturas de mestres locais desprestigiados pela academia por fazerem pintura de gênero "inferior" (os irmãos Le Nain), obras de pintores conscientemente progressistas (Delacroix e Courbet) e práticas artísticas alternativas, como aquelas aprendidas com Couture, além da manipulação ousada da tinta que derivara da pintura espanhola, evocando, segundo Baudelaire, o drama vivo e natural, as emoções, a sensibilité desprovida do racionalismo burguês ${ }^{65}$. Enfim, Manet elege a citação como um elemento fundante da representação, que opera de modo subversivo em relação à narrativa tradicional e aos modelos prévios de sistematização, uma vez que, nestes termos, a citação não é nem a exibição de cultura, nem o pastiche que pretende mostrar a virtuosidade da cópia por si mesma, mas, ao contrário, uma

${ }^{65}$ Para detalhamento dos paralelos entre Manet e a pintura espanhola, ver BROWN, J., BANNER, L. A., SCHULZ, A. e WOLF, R. The Spanish Manner - Drawings from Ribera to Goya. Nova York: The Frick Collection / Scala Publishers, 2010. TINTEROW, G. e LACAMBRE, G. Manet / Velázquez - The French Taste for Spanish Painting. Nova York: The Metropolitan Museum of Art, 2003. 
estrutura compositiva que almeja nos aproximar de uma determinada realidade pelas vias da intensidade do sonho, sem, no entanto, permanecer apenas em seu domínio. Por isso, o pintor convoca ao tribunal da História o cânone artístico mas também, e com peso semelhante, os textos ou imagens "sublimados", que perderam sua "cidadania", ou que jamais dela gozaram. Todos os depoimentos recebem igual atenção. Estruturar deste modo a obra pela citação significa buscar modos de renovação artísticos, alternativos à narrativa linear e à concepção de História como progresso ininterrupto. Trata-se, a partir da desmontagem de um "texto" prévio, da construção de um novo "original".

\begin{abstract}
"A citação interrompe ou mesmo explode o falso continuum do tempo, toma o lugar que antes coubera à empatia (Einfühlung), assim como acontece no teatro épico, onde ela interrompe a ação; ela suspende o contexto presente, deixa-o de lado para se inserir em um novo contexto, caracterizado como uma constelação de perigos (Gefahrenkonstellation). A citação estabelece uma relação entre o agora (Jetzt) e o que já foi; produz essa constelação fulgurante, tão amiúde evocada, do antigo e do presente instantâneo."66
\end{abstract}

A apreciação da crítica especializada foi estreita e implacável. Por não reconhecer - ou não aceitar - que Manet fazia História com os detritos da História, desqualificaria a obra ${ }^{67}$ : um aglomerado de citações perfunctórias, um tema escolhido como pretexto para justaposições superficiais, uma (des)organização geral que visava apenas efeitos estéticos malogrados; um ambicioso fracasso, uma obra imatura, anterior à ruptura modernista de seu

${ }^{66}$ Cf. OEHLER, D. Ciência e poesia da citação no Trabalho das passagens. In Terrenos vulcânicos. São Paulo: Cosacnaify, 2004, p. 242.

${ }^{67}$ Manet submete uma obra ao Salão pela primeira vez em 1859, precisamente $O$ bebedor de absinto: sua primeira recusa, seu primeiro escândalo mas também seu primeiro grande êxito. Será defendido no mundo artístico por Delacroix e no literário por Baudelaire. 
Almoço na relva, de $1863^{68}$. O velho músico é de fato "desconjuntado" se julgado por critérios tradicionais: a organização da composição nos moldes clássicos, a relação imediata entre personagens e paisagem, a especificação categórica do "gênero" em questão, a utilização de uma economia da cor em conformidade com a harmonia do classicismo ou o desenvolvimento de uma estrutura narrativa coerente com as expectativas acadêmicas, internas à obra. Se sob tais critérios o quadro torna-se exemplo de incompetência, sob outros, aqueles produzidos por um Manet na contra-mão do que a normatização dissimulava, a obra é um acúmulo de acertos.

Consideremos a representação dos planos: achatada ao extremo, a perspectiva é encurtada a tal ponto que a paisagem é literalmente reduzida a pano de cena ou "fundo infinito" típico de estúdio fotográfico. A artificialidade da imagem é assim explicitada como construção deliberada de um discurso com ponto de vista marcado; ao espectador não resta senão adentrar a cena e travar contato com seus conteúdos - a pequena área de terra marrom no chão do quadro nos convida, ou melhor, nos impele a nos posicionarmos no interior na tela, em desconfortável proximidade com as personagens (a mesma área nos lembraria da constante ausência de transições sutis entre luz e sombra, ou seja, a criação de zonas cromáticas opostas, estrutural da composição da obra). A inexpressividade dos retratos, atomizados em suas partes, combinada com a aparência de instantâneo fotográfico (a árvore "cortada" à esquerda, o judeu "cortado" à direita, as figuras humanas dispostas como "objetos" na vitrine de um Grand Magasin, a fantasmagórica e bizarra justaposição das figuras decalcadas sobre um fundo que as recusa veementemente, típica dos dioramas e ateliês fotográficos da época, que proporcionam ao artista a possibilidade de fazer qualquer montagem, no limite informando o caráter de "ser para a troca" das personagens) revelam na figuração daquele instante ou, se preferirmos, no

\footnotetext{
${ }^{68}$ Barqueiros... também sofreria duras críticas ao ser apresentado no Salão oficial: um realismo particularmente vulgar, de gente vulgar num lugar vulgar. "Uma versão democrática e risível do famoso Embarque para Cítera, de Watteau. Cf. DAGARRON, É. [et alii]. L'ABCdaire de Manet. Paris: Flammarion, 1998, pp. 29-30.
} 
efêmero, sua parcela de perenidade. Trata-se, sem dúvida, dos excluídos do processo de modernização pelo qual passava Paris, aqui retratados pelo princípio pictórico da "oposição violenta"69, que de imediato explicita conflitos. Naturalmente, a radicalização dos procedimentos artísticos utilizados por Manet radicaliza também o tipo e grau de crítica feito a esse processo. Justapor e deslocar figuras (retratadas nestes termos) que normalmente se encontrariam no meio urbano em um ambiente aparentemente rural, onírico e não identificado Ihes confere um caráter inusitado, estranhamente inquietante, sinistro mesmo, suscitando indagações. O que fazem estes "tipos" neste local? Por que a ausência de idílio campestre, presente nas tradicionais representações deste gênero? Qual a função de um boneco na cena?

Aqui, o mito boêmio convencional é imediatamente dissipado, a começar pela escolha de Lagrène como modelo para a pintura. A figura do cigano era, no imaginário popular, o símbolo do indivíduo excluído, destituído e nômade, suspeito de realizar pequenos roubos que the permitiam a subsistência. A partir de 1830, uma outra imagem se associa à figura, aquela do vagabundo que promove desordem social. Em seguida, um enorme número de ciganos fugidos dos conflitos políticos no leste europeu começou a circular nos portões e arredores de Paris. Lagrène, um deles, sustentara a família trabalhando como operário nas campanhas de reconstrução de Paris até ser ferido em um acidente de trabalho. Passa então a trabalhar como músico de rua, mas impedido pela polícia de executar seu número nas regiões centrais da cidade, onde os ganhos eram certamente maiores, vive como pode, posando como modelo para pintores e desenhistas (o programa de modernização incluía leis de conduta moral contra vagabundagem, mendicância, diversões ambulantes e os chamados forasteiros perigosos, os étrangers dangereux; um dos primeiros atos após o golpe de 02 de dezembro de 1851 previa a deportação de todos os ciganos para Caiena, a capital da Guiana Francesa, ou pelo menos para fora da França). Lagrène tornou-se figura tão famosa no bas-fonds que em determinado momento teve

${ }^{69}$ Cf. FRANCASTEL, P. Histoire de la peinture française. Paris: Éditions Denoël, 1990. 
dificuldade para conseguir emprego posando para artistas: saturava-se, com a exposição de sua figura, a face reconhecível do mito da boemia, ou seja, o boêmio como a quintessência do outsider. Manet expõe, pelo viés da classe, a saturação desta imagem. Em O velho músico, Lagrène passa de objeto a sujeito do processo que o engendrara.

A imagem espetacular da modernização de Paris criara novas formas de miséria e alienação. Aqueles que haviam incessantemente lutado contra o intenso processo de industrialização, contra a retórica da modernização e do progresso "universal" que condenava práticas "antiquadas" de trabalho, perderam as batalhas que lutaram. Após 1848 o trabalho artesanal fora rapidamente substituído pelo industrial. Separação, serialização e quantificação tornam-se a norma da experiência contemporânea. O modelo de modernização partira do centro mas precisava expandir-se: La Petite Pologne era apenas o início do limbo que carecia ser desenvolvido, dilatando os índices de especulação, das taxas de lucros, da criação, da exploração e da permanente disciplina industrial da mão-de-obra operária não-especializada (e, não raro, "recalcitrante"), buscando incessantemente matéria prima barata e, no limite, ampliando o próprio movimento do Capital, que em sua fase financeira, estendia seu domínio da cidade para o faubourg, e deste para a banlieue, as províncias, as colônias e finalmente para outras nações periféricas.

"Nos desajustes entre a subjetividade e a sua função, forjados em estúdio por Manet, aflora um estado generalizado de vacância dos papéis sociais, de mobilidade e disponibilidade das figuras. Todos estão prontos para o que der e vier, daí a incerteza na fisionomia [...]. A dissociação intrínseca entre o sujeito e a função profissional e simbólica é inerente à divisão social do trabalho e às práticas de mercado. Manet pôde observar diretamente as leis deste fenômeno, como processo geral, porque as reformas de Paris, ao expulsarem os 
trabalhadores do centro da capital, a fim de transformar os antigos bairros populares em corredores comerciais e dutos de circulação, pulverizam fisicamente a secular unidade natural entre a casa e a oficina, a vizinhança orgânica entre a moradia do empregado ou aprendiz e seu local de trabalho. As reformas urbanas de Paris prepararam - analogamente ao fenômeno do cercamento das terras comunais na Inglaterra (as enclosures), séculos antes - a mão-de-obra móvel e sem ferramentas próprias, logo disponível como força de trabalho abstrata. [...] A conversão do artesão e seus auxiliares em operários não-qualificados, em unidades de trabalho abstrato, foi concretamente mediada pela urbanização planejada."70

Neste cenário, como propor o tradicional idílio campestre do Cinquecento veneziano tal qual se apresentara em Giorgione ou Ticiano ${ }^{71}$ ? Ao contrário do que the ensinara Couture, Manet está evidentemente questionando e atualizando (re-interpretando) a tradição que o precede: qual a possibilidade de representar a natureza como local de prazer e refúgio tendo em vista a experiência da modernidade? O pintor confronta diretamente o ramo mais nobre da tradição francesa dedicada à pintura de paisagem, aquela dita paysage composé ou paysage de style ${ }^{72}$, Poussin e Claude Lorrain, mas também Corot, a École de Barbizon e mesmo Courbet $^{73}$. Sua apropriação paródica deste

\footnotetext{
${ }^{70}$ Cf. MARTINS, L. R. Manet - uma mulher de negócios, um almoço no parque e um bar. op. cit. pp. 56-57.

${ }^{71}$ No ano seguinte à execução de $O$ velho músico, Manet reativaria a tradição italiana, em outra chave, para compor seu Almoço na relva.

${ }^{72}$ Ao tratar do conflito histórico entre as forças do "real" e do "ideal", o crítico Raymond Bouyer, num artigo de 1893, utiliza o termo "paysage composé" ou "paysage de style". Trata-se da arte do belo, resultado da imaginação inventiva e das escolhas técnicas do pintor, que prefere a representação "ideal" à "real". Esta produção caracterizar-se-ia sobretudo pelo uso (masculino) da linha, e seu exemplo mor é Poussin. Se, ao contrário, o artista valoriza mais o "real" que o "ideal", "copiando" a natureza, criará o que o crítico denominou "paysage rustique" ou "paysage réel", marcada pela (feminina) cor, pelo forte efeito de iluminação e pelo que denominou "um profundo sentimento do verdadeiro". Cf. SHIFF, R. Cézanne and the End of Impressionism - A Study of the Theory, Technique, and Critical Evaluation of Modern Art. op. cit. p. 91.

${ }^{73}$ Argan faz, acertadamente creio, uma distinção entre o realismo de Courbet, "a priori encerrado diante da imutável realidade das coisas", portanto um realismo convencionalmente poético, e
} 
repertório visual apresenta-nos assim "un paysage décomposê", ou seja, uma recomposição e reavaliação de seus elementos típicos, segundo critérios que figurem a verdade estrutural da experiência presente.

A citação da tradição sem aspas explicita-se na figura do boneco ventríloquo, que, como vimos, é evidente referência a Watteau. É certo que este artista inovara a pintura francesa do período rococó ao fazer representações com certo toque de naturalidade, expressão de sentimento, num modo mais rápido de executar o trabalho, tal qual o estado do retratado. Suas referências eram muitas vezes o teatro, sobretudo a comédia (Molière), não os tradicionais temas mitológicos ${ }^{74}$. Como Le Gilles ou Pierrot, de 1721, uma pintura que é também meta-comentário sobre a própria pintura (as discrepâncias entre os modos de representação da figura em primeiro plano, a personagem de teatro, e o fundo nos permitem sugerir que o segundo plano é pintado como um cenário). No entanto, Watteau não estabelece hierarquia no nível das idéias (ou seja, a primazia da idéia única, como pediam Diderot e Baudelaire), privilegiando a representação de diferentes níveis de acontecimento em diferentes planos. Noutros termos, sua pintura era mais denotativa que precisa. Nela não deparamos com verdades, mas com sugestões ou enunciações indiretas de estados, como atesta seu pierrô "songeur et poétique" ("sonhador e poético", segundo a descrição na plaqueta ao lado da tela no museu do Louvre). Quanto à representação da natureza, era famoso por suas fêtes champêtres (o termo entra em circulação no meio artístico após a apresentação da pintura Embarque para Cítera, de 1717, o "morceau de réception" de Watteau na Academia Francesa de Belas Artes). Parte da crítica, da qual Manet certamente discordaria, valoriza o fazer artístico de Watteau como expressão positiva do refinamento e elegância da vida palaciana e burguesa.

aquele de Manet, um pintor que "não trabalha na coisa, mas na própria sensação da coisa". Em Manet, a realidade é sujeito, não objeto. A esse respeito, ver ARGAN, G. C. Manet e a pintura italiana. In A arte moderna na Europa - de Hogarth a Picasso. São Paulo: Companhia das Letras, 2010.

${ }^{74}$ A esse respeito ver BAETJER, K. (ed.). Watteau, Music, and Theater. Nova York: The Metropolitan Museum of Art, 2009. 
"[Watteau] projetou decorações de interiores para os palácios da nobreza, a fim de fornecer um fundo apropriado para as festas da sociedade palaciana. Mas dir-se-ia que as festas reais não satisfaziam a imaginação do artista. Ele começou a pintar suas próprias visões de uma vida totalmente alheia a privações e trivialidades, uma vida fictícia de alegres convescotes em parques de sonho onde nunca chove, de saraus musicais onde todas as damas são belas e todos os amantes esbeltos e graciosos, uma sociedade em que todos se vestem de refulgentes sedas sem aparentarem um ar de chocante ostentação, e onde a vida de pastores e pastoras parece ser uma sucessão de minuetos. Uma descrição como essa poderia gerar a impressão de que a arte de Watteau era insuportavelmente afetada e artificial. Para muitos, passou a refletir o gosto da aristocracia francesa do começo do século XVIII, conhecido como o período rococó, numa predileção por cores e decorações delicadas que sucedera o gosto mais robusto do período barroco e que se expressou em alegres frivolidades. Mas Watteau era um artista grande demais para ser um mero expoente de modas do seu tempo. Pelo contrário, foram seus sonhos e ideais que ajudaram a modelar o estilo rococó. Assim como van Dyck ajudara a criar a idéia de desenvoltura cavalheiresca que associamos às pessoas de nobre estirpe, também Watteau enriqueceu 0 repertório de nossa imaginação, graças à sua concepção de galanteria espirituosa." ${ }^{75}$

O velho músico não toca minuetos que embalam o idílio dos amantes bem nascidos. Ao contrário, desvenda a face oculta da música ligeira de Watteau, representante do prestígio de uma determinada tradição: o preço do sonho da

${ }^{75}$ Cf. GOMBRICH. E. H. A História da arte. op. cit. p. 358 (meus grifos). 
gente de nobre estirpe é o pesadelo da massa de despossuídos; o equivalente à desenvoltura cavalheiresca é a aspereza da experiência moderna, a parcela de danse macabre contida na fête champêtre:

"[à] monarquia burguesa de Luís Felipe só pode suceder uma república burguesa, ou seja, enquanto um setor limitado da burguesia governou em nome do rei, toda a burguesia governará agora em nome do povo. As reivindicações do proletariado de Paris são devaneios utópicos, a que se deve por um paradeiro. A essa declaração da Assembléia Nacional Constituinte o proletariado de Paris respondeu com a Insurreição de junho, o acontecimento de maior envergadura na história das guerras civis da Europa. A república burguesa triunfou. A seu lado alinhavam-se a aristocracia financeira, a burguesia industrial, a classe média, a pequena burguesia, o exército, o lumpen proletariado organizado em Guarda Móvel, os intelectuais de prestígio, o clero e a população rural. Do lado do proletário de Paris não havia senão ele próprio. [...] A derrota dos insurrectos de junho preparara e aplainara, indubitavelmente, o terreno sobre o qual a república burguesa podia ser fundada e edificada, mas demonstrara ao mesmo tempo que na Europa as questões em foco não eram apenas de 'república ou monarquia'. Revelara que aqui república burguesa significava o despotismo ilimitado de uma classe sobre as outras." ${ }^{76}$

A pintura de Manet, cuja execução recorre a elementos do que posteriormente seria a essência da candid photography ${ }^{77}$, é, em seus personagens e cenário, o

\footnotetext{
${ }^{76}$ Cf. MARX, K. O 18 Brumário. São Paulo: Paz e Terra, 2002. pp. 29 e 30-31.

${ }^{77}$ A "candid photography" prioriza a espontaneidade em relação ao apuro técnico e caracterizase pela "imersão" da câmera portátil no evento retratado, não pela construção elaborada da cena em estúdio fotográfico com equipamento de grande formato. Tradicionalmente, opõe-se à
} 
retrato do lumpen proletariado sobre o qual se apoiou Luís Bonaparte: uma massa desagregada, deslocada e flutuante (representada por Manet enquanto tal, na ausência de organicidade das figuras, na afirmação do isolamento de cada parte, na cisão entre figura e fundo e no golpe desferido contra a unidade pictórica do luminismo de um Caravaggio ou um Rembrandt), particularmente vulnerável à manipulação e às ideologias reacionárias, produto do simulacro que se tornava Paris, tão falso quanto seu comandante (Marx faz piada ao chamar Napoleão III de "Robert Macaire no trono"78).

"A pretexto de fundar uma sociedade beneficente o lúmpenproletariado de Paris fora organizado em facções secretas, dirigidas por agentes bonapartistas e sob a chefia geral de um general bonapartista. Lado a lado com roués decadentes, de fortuna duvidosa e de origem duvidosa, lado a lado com arruinados e aventureiros rebentos da burguesia, havia vagabundos, soldados desligados do exército, presidiários libertos, forçados foragidos das galés, chantagistas, saltimbancos, lazzarani, punguistas, trapaceiros, jogadores, maquereaus [alcoviteiros], donos de bordéis, carregadores, líterati, tocadores de realejo, trapeiros, amoladores de facas, soldadores, mendigos - em suma, toda essa massa indefinida e desintegrada, atirada de ceca em meca, que os franceses chamam de la bohème; com esses elementos afins, Bonaparte formou o núcleo da 'Sociedade beneficente' no sentido de que todos os seus membros, como Bonaparte,

"classic photography", a fotografia clássica, que prima pela utilização de técnicas elaboradas em cenas ou cenários cuidadosamente construídos. É considerada o embrião do foto-jornalismo, que, ao recorrer a um determinado número de imagens desta natureza, contaria uma determinada história. Os paralelos aqui estabelecidos com este tipo de produção fotográfica enfatizam a utilização de uma linguagem que seria amplamente desenvolvida pelos meios reprodutíveis: a instantaneidade, a espontaneidade, a transitoriedade, a serialização, a massificação, a quantificação e a montagem. No caso de Manet, mais complexo que a simples dicotomia entre apuro técnico e espontaneidade, as imagens são apreendidas "instantaneamente", ao mesmo tempo em que são também fortemente construídas.

${ }^{78}$ Cf. MARX, K. Les luttes de classes en France. Paris: Éditions Gallimard, 1994, p. 13. 
sentiam necessidade de se beneficiar às expensas da nação laboriosa; esse Bonaparte, que se erige em chefe do lúmpenproletariado, que só aqui reencontra, em massa, os interesses que ele pessoalmente persegue, que reconhece nessa escória, nesse refugo, nesse rebotalho de todas as classes a única classe em que pode apoiar-se incondicionalmente, é o verdadeiro Bonaparte, o Bonaparte sans phrase. Velho astuto roué, concebe a vida histórica das nações e os grandes feitos do Estado como comédia em seu sentido mais vulgar, como uma mascarada onde as fantasias, frases e gestos servem apenas para disfarçar a mais tacanha vilania." ${ }^{\prime 79}$

A mercantilização do pitoresco sedimenta-se na figura do músico no quadro e encontra eco no seu duplo visual, o boneco de ventríloquo. Até mesmo, e por que não? - o pierrô moderno fora deslocado de seu habitat, os teatros da região do Boulevard du Temple (ou, como era popularmente conhecido, o "Bulevar do crime"), mais especificamente o Théâtre des Funambules, que funcionara desde 1813 como teatro de variedades (a palavra francesa funambule significa "pessoa que anda ou dança sobre uma corda estirada; acrobata, dançarino), com conhecidos números como aquele de Baptiste Deburau, famoso por seu "pierrô" modernização da capital que incluía, no campo das artes, a mercantilização da

${ }^{79}$ Cf. MARX, K. O 18 Brumário. op. cit. pp. 78-79.

${ }^{80}$ Baptiste Debureau (1796-1846) transformou a personagem extraída da commedia dell'arte com sua inovadora interpretação no Théâtre des Funambules. As vestes tradicionais do pierrô foram sutilmente modificadas, fazendo nascer uma figura simples, quase andrógina, que permitia ao ator valorizar as delicadas nuances de expressões faciais e corporais, num rigoroso gestual sobre o qual detinha pleno domínio técnico. O reiterado triunfo da personagem nas situações cotidianas representadas no palco, pelo jogo cênico que privilegiava a contínua aparição e a desaparição do artista, atraía uma assídua multidão de populares que frequentava o bulevar para, do paradis, ver seu astuto e solitário herói. Em 1847, Charles Debureau, filho de Baptiste, retoma o papel do pai no teatro. Entre 1854 - 55 é fotografado por Adrien Tournachon, irmão do famoso fotógrafo Nadar, em seu estúdio numa famosa série de clichês que retrata 0 artista de corpo inteiro, como se estivesse atuando no palco. Em 1856 Courbet desenha Pierrot e o braço negro [Pierrot et le bras noir], inspirado na cena teatral do bulevar do crime e nas imagens de Nadar. É provável que Manet tenha também se referido a essa produção visual na composição de seu quadro. Cf. Gustave Courbet. op. cit. e HAMBOURG, M. M. [et alii]. Nadar. Nova York: The Metropolitan Museum of Art, 1995. 
commedia dell'arte (pensemos no iniciante Frédérick Lemaître, que representava em porões da região do Palais Royal mas que logo faria carreira "séria" representando "clássicos" como Kean, de Dumas père). Por esta via, não estaria explicitada em $O$ velho músico, por um lado, o processo de mercantilização da arte e, por outro, o papel do fazer artístico consequente no âmbito da experiência moderna e da estrutura pelo pintor articulada? Não seria uma tela concebida nestes termos o duplo de uma chapa de vidro sensível à luz, cujos efeitos estéticos subordinam-se às teses em função das quais o artista deve tomar posição, e que exige sua passagem da fase de "impressão" para aquela de sua "reprodução"?

"Manet tinha consciência da enrascada em que se encontrava a pintura, após a invenção relativamente recente da fotografia. Ou recusava desdenhosamente a tomada indiferente e impessoal do meio mecânico e industrial (a tese de Baudelaire e dos simbolistas), ou se admitia sua importância e, então era preciso enfrentar decididamente o problema. [...]. A fotografia não interessava tanto como reprodução mecânica ou exata das aparências do real, quanto como impressão direta da luz sobre uma superfície impressionável. [...] Como a chapa fotográfica, o quadro de Manet não quer ser um plano de projeção, mas apenas uma superfície extremamente sensível impressionada por uma realidade em que tudo é fonte luminosa ou superfície iluminada. Prova disso é o uso de brancos e pretos puros, dois extremos entre os quais não pode haver gradação de claro-escuro, mas apenas uma gama de timbres cromáticos"81

Se Olympia (1863) fala de um bem cintilante e desejável à venda, uma metáfora da prostituição geral do trabalhador, e Um bar no Folies-Bergère (1881-82) dá

${ }^{81}$ Cf. ARGAN, G. C. Manet e a pintura italiana. op. cit. p. 421. 
notícia do elo abstrato na circulação intensa que se tornara o trabalhador que não mais negocia por conta própria, O velho músico já dava voz, em 1862, à experiência social daquela parcela que nem sequer tinha direito à "digna exploração". Quem se importa em contemplar antigas vitrines com obsoletas mercadorias, personagens sociais reunidas na e pela linguagem comum da separação que guardam a memória de que tudo que os une é sua ligação com o centro que os mantém isolados ${ }^{82}$ ? Nestes termos, Manet retoma o Daumier de $O$ vagão de terceira-classe, tela de mesmo ano de $O$ velho músico, e o leva às últimas consequências. Seu quadro é um ensaio materialista sobre a experiência da modernidade e um manifesto artístico, cuja bibliografia inclui Marx e Baudelaire.

Em sua flânerie pela capital francesa, Manet, o trapeiro-pintor que encontra seu igual no trapeiro-poeta/ébrio-filósofo das sarjetas parisienses representado em $O$ velho músico, depara com o "inorgânico", recolhe os detritos da cidade, as personagens descartadas pela modernidade e os temas pisoteados pelo progresso, catalogando, examinando, "colecionando" estes resíduos, para então revelar formalmente 0 aspecto que assumiram no processo que os gerou. Entranhado num mercado de arte que se revelava cada vez mais pautado pela ação da censura, do comércio dos marchands e do gosto burguês decaído, Manet não nutria ilusões a respeito do restrito papel que desempenharia na contra-mão do processo de modernização que assolava Paris (neste processo, ele próprio uma mercadoria tanto quanto aquelas que representava em suas pinturas ${ }^{83}$ ). Entretanto, em seu sábio método de triagem de temas e assuntos, avança nos termos artísticos - e políticos - sobretudo porque a técnica e os procedimentos formais dos quais se serve revelam as injunções de um novo

\footnotetext{
${ }^{82}$ A formulação é de Guy Debord. Cf. DEBORD, G. La Société du Spectacle. Paris: Gallimard, 1992.

${ }^{83}$ Quanto à apropriação da obra de Manet pelo mercado, basta lembrar que a influência exercida por marchands como Durand-Ruel (mescla de banqueiro, estoquista e divulgador) ou casas de leilões como o Hôtel Drouot (que incentivava e promovia mostras individuais de Manet na França e no exterior) eram suficientemente significativas para influenciar as práticas artísticas. Monet, por exemplo, tinha, nas décadas de 1880 e 1890, um comprador nos Estados Unidos disposto a pagar entre quatro e seis mil francos por qualquer quadro por ele produzido.
} 
"tempo": ao destruir o paradigma da continuidade temporal em favor de um fragmento "desarticulado" no tempo, Manet isola o objeto para submergi-lo em sua História. "Quando o fluxo real da vida é represado, imobilizando-se, essa interrupção é vivida como se fosse um refluxo: o assombro é esse refluxo. $O$ objeto mais autêntico desse assombro é a dialética em estado de repouso." ${ }^{14}$ Ao pensar materialisticamente, suas pinturas têm lugar num tempo histórico, não metafísico; são instantâneos fotográficos que insistem no fato de que o horror, a beleza, a morte, ou seja, a própria realidade, já não pode ser universalizada, apenas concebida como variante de uma equação concreta em determinado local e momento histórico.

O que outrora fora representado na pintura acadêmica como um "fragmento da vida" torna-se em Manet uma imagem dialética ${ }^{85}$, síntese do ponto de vista crítico, das avaliações e das tomadas de posição do artista. Esta imagem nos revela, nas ruínas da História de uma Paris em vias de modernizar-se, que o obsoleto é também o que há de mais moderno; o ponto de vista do arcaico é privilegiado por seu diminuto grau de mascaramento da realidade. Aqui, os enganos involuntários e bem fundados nas aparências são mais facilmente reconhecidos como tais ${ }^{86}$. Os sinais da derrota são evidentes e não vêm desacompanhados da memória que guardam em si suas personagens: o escárnio do vitorioso em relação ao derrotado, os destroços materiais e morais produzidos pela vitória do Capital, a desmoralização do pensamento dialético e a lembrança das contínuas lutas pela efetivação de promessas políticas descumpridas.

\footnotetext{
${ }^{84}$ Cf. BENJAMIN, W. Que é o teatro épico? Um estudo sobre Brecht. In Obras escolhidas magia e técnica, arte e política. op. cit. pp. 89-90.

${ }^{85}$ A formulação é de Walter Benjamin, desenvolvida ao longo de seu inconcluso Trabalho das Passagens. Para referências e análise da obra, ver BUCK-MORSS, S. The Dialectics of Seeing - Walter Benjamin and the Arcades Project. Cambridge, Massachusetts: The MIT Press, 1991.

${ }^{86}$ A formulação é de Roberto Schwarz. Cf. As idéias fora do lugar. In Ao vencedor as batatas. São Paulo: Livraria Duas Cidades, 1988.
} 
O músico que nos encara sussurra os gritos deste pesadelo coletivo. Manet, ao dar voz a uma de suas personages, explode o modo de cognição tradicional, explicita o processo de fabricação da obra de arte e cita o que jamais fora "escrito" pela pintura do período, sonhando o futuro no presente do século XIX. 


\section{CAPÍTULO 3:}

Eugène Atget, fotógrafo da vida moderna

"Foi-se a velha Paris (de uma cidade a história

Depressa muda mais que um coração infiel)"1

"E, ébrio de minha loucura, gritei-Ihe furioso:

- O lado belo da vida! O lado belo da vida!"2

"Não existem, nas vozes que escutamos, ecos de vozes que emudeceram?"3

"A arte do futuro não será uma guloseima, mas trabalho transformado"4

Pequenas ruas ermas e sombrias, parques e jardins inabitados, pontes que parecem não levar a parte alguma, bulevares desertos, fachadas lúgubres, interiores mórbidos, passagens soturnas: a Paris de Eugène Atget é, por assim dizer, uma cidade inanimada. O espaço urbano, associado às frenéticas convulsões da vida moderna, à agitação comercial e à dinâmica industrial capitalista do final do século XIX, tão enfatizado nestes termos pela pintura impressionista, pela literatura e pela produção fotográfica do período é, em Atget, congelado e reduzido. O projeto de higienização da "nova" Paris, iniciado

\footnotetext{
1 "Le vieux Paris n'est plus (La forme d'une ville / change plus vite, helas! que le cœur d'un mortel)". Cf. O Cisne. In BAUDELARE, C. Poesia e prosa. Rio de Janeiro: Editora Nova Aguilar S. A., 2006, p. 172.

2 "Et, ivre de ma folie, je lui criai furieusement: la vie en beau! La vie en beau!" Cf. O Mau vidraceiro. In BAUDELAIRE, C. Poesia e prosa. op. cit. p. 286.

${ }^{3}$ Cf. BENJAMIN, Walter. Obras escolhidas - magia e técnica, arte e política. São Paulo: Editora Brasiliense, 1993, p. 223.

${ }^{4} \mathrm{Cf}$. TARABOUKINE, N. Le dernier tableau - du chevalet à la machine - pour une théorie de la peinture. Écrits sur l'art et l'histoire de l'art à l'époque du constructivisme russe, présentés par Andrei Nakov. Paris: Éditions Champ Libre, 1980, p. 56.
} 
oficialmente em 1833 sob o governo de Louis-Philippe e de seu então prefeito, o conde de Rambuteau, que em seu discurso de posse já explicitara os motivos do Estado para as reformas então propostas, "a preocupação de propiciar aos parisienses água, ar e sombra fresca", encontra na produção fotográfica de Hippolyte Bayard a expressão máxima da valorização desta expedição que, apoiada nas recentes teorias de higiene que amparavam o projeto moral e cientificamente, veria concluídas obras como o Arco do Triunfo, a Place de l'Étoile e a avenida dos Champs-Élysées (além do embelezamento de outros pontos da cidade com fontes, bulevares e luz a gás). Outros artistas-fotógrafos retratariam as "melhorias" sucessivamente implementadas: Baldus, Le Gray, Le Secq, Mestral, e finalmente Charles Marville, Collard e Durandelle, cujas imagens, verdadeiras peças publicitárias, repisam a premência e o sucesso das campanhas de modernização, levadas ao extremo pelo Barão Haussmann depois dos bombardeios de Cavaignac.

Ao contrário de seus predecessores, Atget deprecia esta cidade, desmistificando-a e circunscrevendo-a num ambiente que denota coibição, ausência, subtração. Se a Paris haussmannizada é aquela do fausto, a de Atget será um campo em ruínas. E para melhor examiná-las, tentando desvendar parte do que ocultam seus escombros, proponho um percurso que incluirá considerações sobre 1. o processo de modernização pelo qual passara a cidade no século XIX, 2. parte da biografia do fotógrafo, que elucida tanto sua "escolha" pela fotografia como seus métodos de trabalho, 3. o conceito de "documento fotográfico" produzido por fotógrafos com status semelhante ao de Atget para, somente então, 4. avaliar um pequeno conjunto de imagens, representativo da natureza e do teor da crítica que faria, no conjunto de sua obra, ao processo de modernização em curso - os retratos dos pequenos ofícios em vias de desaparecimento, os petits métiers. Gostaria, por fim, de estabelecer alguns paralelos entre sua produção fotográfica e a literatura do período, bem como seu diálogo com a precedente tradição pictórica, considerando o que acredito ser 
tanto uma retomada - e atualização - de procedimentos técnicos e artísticos como um significativo avanço e alargamento de suas possibilidades expressivas.

As tentativas de expansão e imposição dos modelos econômicos, políticos e sociais ditados a partir de Paris intensificam-se ainda na primeira metade do século XIX. Para o sucesso da empreitada capitalista, a cidade carecia de ordem e controle, mas assegurá-los apenas no interior de suas fronteiras não significava garanti-los. Trata-se, desde o início, de uma dupla tarefa: atrelar o desenvolvimento da cidade ao da banlieue, do centro àquele da periferia, condição sine qua non para a perfeita imposição de uma ordem já constituída em esfera global.

"[No século $X I X]$ o modelo liberal era inalcançável para a grande maioria das demais nações, cujas condições eram outras, mas era também indescartável, porque representava a tendência de ponta no sistema internacional. São contradições objetivas. [...] No século XX o modelo norteamericano e ultimamente a fórmula neo-liberal funcionam de maneira análoga, como paradigmas quase incontornáveis. Parafraseando Marx, as idéias da classe dominante na nação hegemônica do período tendem a ser dominantes ou pelo menos presença obrigatória nas nações periféricas. Quem as adota tais quais é apologista ou deslumbrado. Quem pensa que as pode desconhecer coloca-se intelectualmente fora do mundo. Dentro do possível, tudo está em relacionar-se com elas de maneira judiciosa, reconhecendo sua parte de necessidade, mas sem perder de vista as realidades e os 
interesses próprios. Na verdade, quem foi eurocêntrico e depois impôs o padrão americano foi o capitalismo."

A periferia de Paris (mas também as de Poitiers, Perpignan, Nîmes, Reims, Clermont, Ferrand, Lille, Lyon, Le Havre, Saint-Étienne ou Tours) representava na França do início do século XIX a idéia de uma enorme ameaça, porém não menos associada às gigantescas possibilidades de lucros efetivos em várias frentes. As ameaças: com a industrialização dos subúrbios veio a proletarização dos trabalhadores, não desacompanhada de suas correlatas tentativas de organização política. É certo que as elites temiam a expansão da violência indiscriminada, da prostituição, dos ociosos dangereux e dos hábitos pouco salutares nas margens das cidades. Mas o que parecia verdadeiramente insalubre a seus olhos era a crescente organização dos trabalhadores, que precisamente por estarem fora dos limites das cidades, encontravam maiores possibilidades de sobrevivência física e de articulação de uma rede interligada de relações pessoais de sociabilidade e cooperação mútua (incluindo uma produção artística, que compreendia a criação de festivais com música e outras artes) que rapidamente evoluiriam para o âmbito da organização sindical e política, com protestos que instauravam inclusive greves.

De início, estes trabalhadores escapavam do pagamento do octroi, um imposto sobre algumas mercadorias básicas - as mais rentáveis - como vinho, óleo, açúcar, café, dentre outras, recolhido no perímetro urbano e destinado à construção e manutenção de fortificações e "obras de interesse público" (o termo "octroi" designa também os locais onde o imposto era recolhido, edifícios especialmente construídos às portas das fortificações citadinas, fotografados mais tarde por Atget). Logo desenvolveu-se, nas margens das cidades, as zones, um comércio paralelo, destinado a abastecer os moradores locais de dentro e fora dos limites urbanos, os exilados impedidos de circular pelas áreas

5 Entrevista de Roberto Schwarz. In GONÇALVES, M. A. e CARIELLO, R. Desapareceu a perspectiva de um progresso que torne o país decente. Folha de São Paulo. Ilustrada, pp. E 8 9, sábado, 11 de agosto de 2007. 
centrais, as prostitutas, os integrantes de bandos, os agentes de controle, mas sobretudo os cabaretiers que abasteciam as chamadas guinguettes, cabarés populares que funcionavam como restaurante e local de bailes. Ali tinham lugar as famosas goguettes, reuniões nas quais se discutia política sob pretexto de beber e se divertir6. As goguettes parisienses não apenas lideravam em tamanho, mas também em grau de organização e articulação política, um modelo que "exportavam" para guinguettes de outras periferias francesas. No atual vigésimo arrondissement de Paris, então conhecido apenas por Belleville, um fauboug (ou zona anexada da cidade), os encontros aconteciam no Théâtre de Folies-Belleville ou em seu feroz concorrente, a Salle Favié, que de guinguette rural administrada por Père Favié rapidamente transformara-se em um enorme salão de baile, onde, a despeito das inúmeras tentativas contrárias de seu proprietário, centenas se reuniam para ouvir, dentre outros, inflamados discursos oposicionistas de Leon Gambetta ou de Jules Vallès. Paulatinamente, os avessos proprietários perderiam completamente a pouca influência que tentavam exercer sobre as reuniões: durante a Comuna, por exemplo, Louise Michel estava entre as que atraiam multidões ao salão, vindas especialmente para ouvi-la7. A burguesia citadina "civilizada", por sua vez, tinha plena ciência que o perigo não residia nos "déclassés", mas nos trabalhadores organizados, os artesãos que pleiteavam mudanças distintas daquelas que viam instaurar-se com insuspeitada rapidez, a saber, os novos modos, métodos e organização do trabalho que se impunham sem precedentes, ainda mais hostis que aqueles já praticados e sobre os quais os trabalhadores perdiam o controle, em passo acelerado e em sangrentas batalhas.

O episódio do massacre da Rue Transnonin é exemplo paradigmático deste processo. O governo de Louis-Philippe I, marcado por uma série de revoltas populares, é o cenário da chacina. Em abril de 1834 uma manifestação foi

${ }_{6}^{6}$ Para maiores referências a respeito da história das gogettes, seus artistas-cantores e suas canções, ver BOISSON, M. Charles Gille ou le chansonnier pendu (1820 - 1856) - Histoire de la gogette. Paris: J. Peyronnet \& Compagnie, Éditeurs, 1925.

${ }^{7}$ Michel detalharia todo o processo que levara à Comuna, seus dias e seu fracasso em MICHEL, L. La Commune - Histoire et souvenirs. Paris: La Découverte \& Syros, 1999. 
organizada em Lyon pela Société des Droits de l'Homme, associação política clandestina sob o reinado do monarca, e pelo Conselho Executivo das Sociedades Trabalhistas de Auxílio Mútuo contra uma série de leis implementadas pelo governo para exterminar a incessante propaganda política republicana. Tais leis regulamentavam, dentre outras, a atuação de dois grupos profissionais, duas categorias de pequenos ofícios, os crieurs publiques, trabalhadores que anunciavam em voz alta as proclamações e decretos públicos, e os vendedores de jornais. A nova lei lhes impunha a obrigatoriedade de portar uma autorização oficial, revogável a qualquer momento caso fossem considerados inadequados para o exercício da profissão ("inadequados" significava, no mais das vezes, "politicamente inconvenientes"). À insatisfação destes soma-se a revolta dos tecelões de seda, que logo alcançaria a capital. Adolphe Thiers, ministro e presidente do conselho da Monarquia de Julho, propositalmente permitiria que o levante obtivesse certo êxito para, em seguida, e como parte de sua estratégia política e propagandística, massacrá-lo. Seu fim se dá com o morticínio de vários trabalhadores, dentre os quais uma família habitante de um apartamento em um edifício da rue Transnonain, no centro (operário) da capital francesa (cena posteriormente imortalizada na lendária litografia de Daumier, de 1834).

O Barão Georges-Eugène Haussmann, prefeito de Paris escolhido por LouisNapoléon que inicia em 1853 sua atuação no processo de modernização em curso, reflete em suas memórias com surpreendente lucidez sobre o episódio: "O subsequente trabalho que completa a construção da rue de Turbigo fez com que a rue Transnonain desaparecesse do mapa de Paris!"8 O que de fato deveria desaparecer do mapa e da memória da cidade, juntamente com as marcas da resistência obstinada de luta, era uma determinada forma ou método de organização do trabalho, aquele dos trabalhadores que viviam e trabalhavam no quartier, em seus arredores e no edifício da rue Transnonin invadido por

\footnotetext{
8 Citado em MERRIMAN, J. M. The Margins of City Life - Explorations on the French Urban
} Frontier, from 1815 - 1851. Nova York e Oxford: Oxford University Press, 1991, p. 224. 
Thiers. O local era particularmente representativo de uma certa estrutura de trabalho na Paris anterior às grandes reformas de Haussmann. Ali, cerca de trinta artesãos exerciam diversas atividades profissionais ligadas aos chamados pequenos ofícios, dentre as quais, joalheiros, chapeleiros, douradores de papel, seleiros, escultores de bronze, pintores de parede, artistas pintores, artistas de teatro (o teatro do bairro oferecia em média de dois a três espetáculos de variedades por semana), cortadores de pedra, costureiros, vidraceiros, polidores de metal e costureiras especializadas em remendar roupas íntimas femininas. Os profissionais ocupavam o espaço segundo suas posses: no térreo ficavam os donos das lojas e os artesãos mais abastados, no primeiro e segundo andares os artesãos um pouco menos endinheirados que os primeiros e algumas pequenas empresas; nos andares superiores os empregados, aprendizes e diaristas. As atividades artesanais, o comércio e a moradia se aproximavam umas das outras. Os trabalhadores habitantes do edifício viviam em cômodos adjacentes às oficinas ou empresas em que trabalhavam e detinham, ainda que parcialmente, algum controle sobre o processo de produção.

Após o massacre, os moradores não deixaram o edifício. O episódio impunha um desafio aos futuros administradores da cidade. A Haussmann coube a questão: como resolver os problemas de utilização de capital excedente e absorção de mão-de-obra desempregada, frutos da crise de 1848, além de sanear o local política e economicamente, criando oportunidades de investimentos, assegurando lucros para investidores que, como o próprio Haussmann, concebiam Paris como um imenso campo de prospecção para, sem maiores resistências, afiançar a saúde e o bem-estar da ordem capitalista vigente? Ciente de sua missão, de imediato compreendeu que:

"desde o início, as cidades nasceram graças às concentrações geográficas e sociais dos excedentes da produção. A urbanização sempre foi, portanto, um fenômeno de classe, uma vez que excedentes são extraídos de algum 
lugar e de alguém, ao mesmo tempo que o controle sobre sua distribuição encontra-se em poucas mãos. Naturalmente, este quadro geral persiste sob o capitalismo; mas, uma vez que a urbanização depende da mobilização de um excedente de produção, uma estreita conexão emerge entre 0 desenvolvimento do capitalismo e a urbanização. Os capitalistas devem gerar excedentes de produção para produzir excedente de valor, que devem, por sua vez, serem investidos para produzirem mais excedente de valor. $\mathrm{O}$ resultado desse investimento contínuo é a expansão do excedente de produção numa taxa composta - daí as curvas logísticas (dinheiro, produção e população) ligadas à história da acumulação de capital, em paralelo ao crescimento da urbanização sob o capitalismo."

Nestes termos, as decorrentes formas de organização social advindas das novas dinâmicas - reflexo consequente da nova geografia da cidade e do modo como o dinheiro passara a ali circular - estavam longe de ser mera redecoração urbana ou cultural; eram de fato a imagem de uma mudança econômica global. Para avigorá-la, o prefeito não poupou esforços: 1. fez avançar a anexação de comunas periféricas, ampliando a extensão do controle policial e o aumento na arrecadação de impostos (ao representar um casal de miseráveis em frente a seu casebre contemplando Paris ao longe, Daumier dera notícia do fato em 1860 na litogravura intitulada "E dizer que agora somos parisienses!", publicada no Album des charges du jour), 2. promoveu a quebra de monopólios estatais visando lucros privados (como a quebra do monopólio da companhia de táxis e o fomento à fabricação de lâmpadas de rua para a iluminação da "nova" Paris) e 3. reorganizou as finanças e o crédito para, com a colaboração das hautes banques (Rothschild) e a visão empreendedora de alguns administradores

9 Cf. HARVEY, David. The Right to the City. In New Left Review n. 53, Second Series, September - October, 2008, p.24. 
(Persigny, os irmãos Pereire e o próprio Haussmann) o crédito passasse a ser universal, permitindo a associação de capital (sem a qual as reformas urbanas simplesmente não seriam possíveis ${ }^{10}$ ) e desatravancando quaisquer impedimentos à especulação, que autorizava e regia o desenvolvimento da cidade (as batalhas travadas entre os integrantes da alta burguesia no campo das altas finanças para tomar parte nas negociações ilícitas e se beneficiar dos incomensuráveis lucros obtidos no processo de modernização da cidade seriam assunto do posterior L'Argent, de Zola). O prefeito remodelou a cidade de modo a não apenas expulsar a classe trabalhadora do centro para as periferias (naturalmente com vistas à valorização do mercado imobiliário, que fazia crescer em proporção geométrica em determinadas áreas centrais da cidade), mas também para a melhor circulação de mercadorias e tropas de soldados. $O$ barão não desejava outras insurreições na cidade, ao menos nenhuma com chances de vitória ${ }^{11}$. Tratava-se, portanto, também de profilaxia anti-revolucionária.

"Aqui se aborda o aspecto mais importante da
haussmannização: seu caráter de 'embelezamento
estratégico' (a expressão data dos anos 1860). O 'fato
estratégico' comanda [...] o 'retalhamento da antiga capital'.
Entretanto, é Friedrich Engels quem melhor resume o desafio
político-militar dos trabalhos de Haussmann: trata-se,
escreve, da 'forma especificamente bonapartista de abrir
longas artérias retas e largas através de bairros operários de ruas estreitas', com o objetivo estratégico de tornar 'mais

\footnotetext{
10 Para o detalhamento do financiamento dos trabalhos de modernização de Paris ver MONCAN, P. Le Paris d'Haussmann. Paris: Les Éditions du Mecène, 2009.

11 '"Arquiteto demolidor', Haussmann, pela abertura das grandes avenidas e bulevares, embeleza a cidade encarecendo os aluguéis, expulsando de Paris o proletariado, a tiros de canhão contra as barricadas [...]. [C]oncebe a metrópole, à diferença da cidade, como terreno da luta social, vê a cidade do ponto de vista do interesse capitalista. Abre Paris à especulação do grande capital financeiro, alienando seus antigos moradores, proscrevendo-os para seus arredores e periferias, utilizando a cidade diretamente como mercadoria. Com Haussmann, Paris vive 'as mais belas horas da especulação'; na modernidade, tudo é cálculo e interesse, e as avenidas abrem-se para a livre circulação do capital". Cf. MATOS, O. A cena primitiva - capitalismo e fetiche em Walter Benjamin. In Discretas esperanças - reflexões filosóficas sobre o mundo contemporâneo. São Paulo: Nova Alexandria, 2006, p. 70.
} 
difíceis [...] os combates de barricadas. Os bulevares retilíneos tinham, entre outras, a grande vantagem de permitir a utilização do canhão contra eventuais insurretos - uma situação profeticamente evocada em uma frase de Pierre Dupont, em 1849, citada por Benjamin [em Das PassagenWerk] em epígrafe no capítulo sobre a haussmannização: 'as capitais palpitantes são abertas pelo canhão'.

Em resumo, os 'embelezamentos estratégicos' do barão Haussmann eram um método racionalmente planejado de cortar pela raiz qualquer desejo de revolta; e se, apesar de tudo, ela ocorresse, de esmagá-la de modo eficaz - fazendo uso do último recurso dos poderosos, segundo Benjamin, o sangue...."12

Ao remodelar a cidade, o barão "matara" a rua e o quartier para criar os grandes bulevares. Dessa morte advém uma série de transformações nos serviços e informações conectados de várias maneiras à vida doméstica. O contexto da indústria era, como vimos na descrição da vida cotidiana do edifício da rue Transnonain, o quartier - coeso, separado e conhecido intimamente entrelaçando negócios e formas de sociabilidade: a burguesia "do bairro" era também parte do quartier. Ao homogeneizar os negócios da cidade, o prefeito de Paris abre campo desimpedido para a livre empresa: as grandes lojas de departamentos, espetáculo público da opulência privada, serão o signo e o instrumento da substituição de uma nova forma de capital por outra, que obedeceria a lógica geral do processo de haussmanização (descrito em $A u$ Bonheur des Dames, de Zola) ${ }^{13}$.

12 Cf. LÖWY, M. A cidade, lugar estratégico do enfrentamento das classes - insurreições, barricadas e haussmannização de Paris nas Passagens de Walter Benjamin. In Margem Esquerda - ensaios marxistas n. 8. São Paulo: Boitempo Editorial, novembro de 2006, pp. 69 70.

13 "O crescente poder da própria mercadoria como espetáculo era melhor expresso pelas novas lojas de departamento. O Bon Marché, que abriu as portas em 1852, foi o pioneiro, seguido pela 
Assim, a mercadoria abandona em definitivo o quartier. A mecanização crescente, a queda nos preços das matérias-primas, as regras de eficiência e produtividade implantadas na produção e o aumento progressivo dos índices de exploração da mão-de-obra barata, abundante e não-especializada, consente maior acessibilidade às mercadorias e "democratiza" o consumo conspícuo, particularmente o de vestuário neste momento (Daumier e Guys fariam críticas mordazes às contínuas mudanças ditadas pela moda). O leque de produtos e consumidores alarga-se para abarcar até mesmo as camadas mais populares da população: a classe média baixa e os trabalhadores solteiros ou um pouco melhor remunerados. Neste cenário, o trabalhador perde por completo todo 0 controle e o conhecimento do processo de produção. A segmentação de tarefas, a especialização da mão de obra, a aniquilação do artesanato como sujeito histórico e a consolidação do trabalho assentado no processo industrial instaura um quadro de absoluta alienação. Em outras palavras:

“...] a Paris de Haussmann não era uma forma neutra na qual
o capitalismo casualmente se desenvolvia: era uma forma de
capital, e uma das mais efetivas. As cidades estavam entre os
melhores investimentos disponíveis, pelo menos nos termos

loja do Louvre em 1855 (embora suas primeiras atividades datem dos anos 40 do século XIX). Estas lojas com alta rotatividade de mercadorias careciam de uma vasta clientela atraída de todas as partes da cidade; os novos bulevares facilitavam tal movimento. As vitrines eram organizadas como chamarizes para a contemplação do passante. As mercadorias, em conspícuas pilhas no interior das lojas de departamentos, tornaram-se um espetáculo em si. As lojas davam para a calçada e encorajavam a entrada do público sem a obrigação de comprar. Um exército de atendentes e vendedores (moças e rapazes particularmente sedutores) patrulhavam o comportamento no interior do espaço ao mesmo tempo em que procuravam atender o desejo dos consumidores. A sexualidade envolvida na operação era flagrante. As mulheres, portanto, desempenhavam um papel de destaque, tanto como compradoras como vendedoras. Mouret, o proprietário fictício de uma loja como o Bon Marché no romance de Zola Au Bonheur des Dames, explica as técnicas dos 'negócios modernos' para um barão (talhado, obviamente, segundo a figura de Haussmann). [...] A arte do chamariz começava na vitrine. [...] Mouret foi retratado como 'o melhor vitrinista de Paris, um vitrinista revolucionário que fundou a escola do brutal e do desmedido na arte do exibir. [...] A relação de simbiose entre os espaços comerciais e públicos e sua apropriação pela via do consumo tornou-se crucial. O espetáculo da mercadoria passou a dominar a relação entre público e privado e efetivamente unificou os dois. Porém se o papel da mulher burguesa parecia assumir um status mais elevado na progressão das passagens para as lojas de departamento, ainda lhes cabia ser exploradas, desta feita mais como consumidoras do que como administradoras do lar". Cf. HARVEY, D. Paris, Capital of Modernity. Nova York e Londres: Routledge, 2006, pp. $212-217$. 
do Barão Haussmann; e da massa de lucros produzidos em torno da Place de l'Alma e da rue de Turin veio o capital para financiar as novas fábricas em La Villette ou para impulsionar o movimento da La Samaritaine.

Todavia, os inimigos da haussmanização queriam dizer mais ou menos que isso. Eles não tinham a noção precisa de como a obra do barão se conectava com o capitalismo, nem se interessavam por sua lógica financeira - à parte as acusações de dissimulação e desperdício. O que era vívido era a percepção de alguma espécie de vida que a haussmanização havia destruído. Diziam ter perdido a cidade, que esta lhes fora roubada. Era o seu modo de dizer que o capital invadiu e rompeu a economia do quartier; que se tornara uma força separada e insistente no interior do mundo do trabalho, e que o que ele destruiu era uma forma de vida que havia sido Paris para a maioria dos habitantes da cidade."14

A primeira opção do jovem Jean-Eugène Atget não era a carreira de fotógrafo mas aquela de ator dramático. Nascido em 1857 em uma família de trabalhadores pobres de Libourne, região sudoeste da França, o garoto logo se viu órfão de um pai que construía carroças (o então petit métier era denominado "charron" ou "carrossier") e de uma mãe sem profissão. O tio que se encarregou de sua criação lhe destinara, a princípio, o ofício de padre. No entanto, levados pela necessidade, em breve se mudariam para os arredores de Paris, que acolhia imigrantes prontos para toda sorte de pequenos serviços. No final de sua

${ }_{14}$ Cf. CLARK, T. J. A pintura da vida moderna - Paris na arte de Manet e de seus seguidores. op. cit. pp. $105-106$. 
adolescência, agora em Bordeaux, consegue emprego de ajudante geral num barco de saída para o Uruguai, no qual faria sua única grande viagem (embora, tempos depois, e com a habilidade de um ator cômico, narrasse as inúmeras aventuras fictícias vividas como funcionário da marinha) ${ }^{15}$.

Em 1878 Atget encontra-se novamente em Paris, onde frequenta o curso de comediante no Conservatoire National de Musique et de Déclamation para logo abandoná-lo: as obrigações com o serviço militar o impedem de dedicar-se integralmente aos estudos de arte dramática. Sua carreira de ator tem início logo em seguida e, segundo o próprio fotógrafo, alcançaria seu clímax na interpretação de Robert Macaire no Théâtre des Nations, atual Théâtre de La Cité. Sabemos, no entanto, que esta é também parte de uma de suas possíveis blagues:

"Infelizmente, de acordo com os arquivos do teatro, sabemos que a peça foi encenada no dia primeiro de maio de 1883 com Montbars como intérprete. Se é que representou o papel [de Macaire], Atget o fez em sessões de reprise ou como ator substituto, sem dúvida em estabelecimentos de periferia ou de quartier: Montparnasse, Grenelle, Les Gobelins. Esta é a hipótese mais verossímil. Ele foi sobretudo um ator de província." ${ }^{\prime 6}$

O certo é que como ator Atget não obteria o sucesso desejado, como um Charles Le Bargy, societário da Comédie-Française, um Jacques de Féraudy, ator, diretor e roteirista ou aquele que seria considerado o maior comediante de sua época, Lucien Guitry (uma versão masculina de Sarah Bernardt, com quem

15 "Os dizeres de Atget são comumente passíveis de suspeita e nem sempre se encontram em conformidade com os fatos reais. [...] Por que indica Bordeaux como seu local de nascimento? Suspeitamos que suas inúmeras viagens marítimas tenham se reduzido a uma apenas." Cf. LEROY, J. Atget - magicien du vieux Paris. Joinville le Pont: Pierre Jean Balbo Éditeur, 1975. A esse respeito, ver também BEAUMONT-MAILLET, L. Atget Paris. Paris: Hazan, 1992.

${ }^{16} \mathrm{Cf}$. LEROY, J. Atget - magicien du vieux Paris. op. cit. 
frequentemente representava), todos, segundo Atget, seus camaradas no início da carreira. Traços físicos por demais marcados, um sotaque de província carregado e desprovido do "refinamento" daquele que se ouvia na capital e a ausência de meios e relações que permitissem circulação e ascensão no mundo do teatro "sério" parisiense conferem a Atget a fama de ator medíocre. Até 1888 atuou em comédias montadas por pequenos grupos de teatro em turnês na província ou na banlieue, sempre em papeis terciários, sobretudo aqueles de traidor ou delator, quando, devido a uma doença nas cordas vocais, foi finalmente demitido. Diante do inegável fracasso de sua carreira dramática e das necessidades materiais que se impunham, Atget decide tentar suas chances como artista pintor em Montparnasse.

"Quais eram os assuntos que estavam na ordem do dia quando [Atget] se encontra na capital? Na política, WaldeckRousseau presidia o Conselho de Ministros e Loubet estava no Élysée. No mundo do espetáculo, a Comédie-Française perdia Le Bargy e o Folies-Bergères anunciava Yvette Guilbert em sua programação. Os parisienses viam chegar ao fim as obras na Ponte Alexandre III e o Observatoire de Nice descobria um novo cometa. Entretanto, os diferentes aspectos da atualidade não despertavam maiores interesses em Atget. Não mais poder atuar no teatro era uma desgraça sem tamanho, um choque grande demais. Mas em seu coração partido restava uma esperança: Montparnasse the daria o que Melpômene [a musa da tragédia] Ihe havia recusado. Será à pintura que pedirá uma chance."17

O Atget pintor instala-se em sua residência-ateliê da rue Campagne-Première e inicia sua produção a óleo. As cenas urbanas que recobrem as paredes dos cômodos jamais foram vendidas. $O$ pintor certamente não detinha 0

${ }^{17}$ Cf. LEROY, J. Atget - magicien du vieux Paris. op. cit. 
conhecimento e o controle técnico necessários para a execução das pinturas, como revelam as pouquíssimas telas sobreviventes do período, $A$ árvore morta e uma paisagem sem título. Atget não era um colorista nato, não sabia manipular o pincel com destreza, mesclar as tintas nem tampouco dispor os elementos no plano. Em suma, não era nem um autodidata nem um talento natural. Frequentar escolas de pintura como a Academia de Belas Artes ou tomar aulas particulares era, para aquele que se via frente a iminência da miséria mais absoluta, uma alternativa que simplesmente não se configurava em seu horizonte. O pintor, que já havia fotografado na condição de amador, vislumbra a possibilidade de retomar a atividade como profissional: vários pintores de Montparnasse, seus então colegas de ofício, manifestavam o desejo e a necessidade de obterem fotografias ou gravuras a partir das quais pudessem realizar suas pinturas a óleo. Nem sempre disponíveis, encontravam dificuldade para adquiri-las e Atget, que mais uma vez deparara com o fracasso como artista, não poderia desperdiçar a chance de conseguir algum dinheiro. "Rebaixado" à condição de fotógrafo, restava-lhe somente produzir tais imagens ou, como seriam posteriormente conhecidas, "os documentos para artistas", a partir dos quais nasceriam as grandes "obras de arte" que ele era incapaz de produzir em suas telas.

"Atget sente rapidamente que trilha a estrada errada. $O$ balanço é desastroso e os frutos são ainda mais amargos do que aqueles colhidos do teatro. Há dezoito anos aguardava em vão um milagre, mal podendo sobreviver, nutrindo insensatas ilusões. Mas a pintura se recusava mesmo a darIhe de comer. Era a mais insuportável miséria [...]. Atget enfim compreendeu que estava diante de uma encruzilhada. Artista, ator cômico ou pintor eram termos excluídos de seu universo. Por muito tempo acreditara poder deixar o palco sob a aclamação pública e o doce ruído dos aplausos. Esta sorte fora reservada a outros. [...] Um certo número de desenhistas 
e pintores que executavam suas obras sem o auxílio de um modelo vivo [de chic] mas com a ajuda de gravuras ou estampas lamentavam não poder encontrar a documentação desejada tão facilmente. Nem surdo nem idiota, [Atget] concluiu que talvez pudesse simplificar a tarefa destes pintores vendendo-lhes a documentação necessária. Foi assim que considerou seriamente tornar-se fotógrafo profissional. Quando se acredita possuir as qualidades, as aptidões de um grande ator (ele jamais suportou sua expulsão da cena teatral), tornar-se fotógrafo ambulante, que descenso! Ser um artista e cair na fotografia! [...] Não era este novo estágio que o fazia sofrer, mas não mais poder exercer sua primeira atividade profissional. Sua vida foi uma desilusão amorosa [un chagrin d'amour]."18

O que parecia insuportável a Atget era o fato de que sua "demoção" condizia com a posição social rebaixada que ocupava, marcando-o indelevelmente em sua condição de trabalhador empobrecido e lembrando-o da impossibilidade de ascensão social universal pelo caminho das artes (ou por qualquer outro!), sobretudo daquelas consagradas e estabelecidas na figura das grandes instituições que as representavam, preservando seus tradicionais valores, usos e funções no âmbito de um mercado já plenamente constituído e em operação (no caso do teatro, a Comédie-Française e da pintura, a Escola de Belas Artes e os Salões). No campo da fotografia, a situação não era distinta: ser fotógrafo significava ser fotógrafo pictorialista, ou seja, um artista-fotógrafo atrelado aos influentes clubes e instituições, cujos membros, integrantes da classe média e da (alta) burguesia, tentavam, em suas horas livres, aproximar o novo meio de expressão do prestígio de artes mais nobres e já entronizadas como tais: "A nova escola de fotografia", diria o banqueiro de formação jesuíta Robert Demarchy, "que chamamos de pictorialista por falta de melhor qualificação,

${ }^{18}$ Cf. LEROY, J. Atget - magicien du vieux Paris. op. cit. 
pretende ir de encontro à velha escola do documentário, de multiplicar as ocasiões de controle e de aumentar sua força. Estas são, em suma, suas tendências." ${ }^{19}$ Atget não tinha horas de folga remuneradas nem tampouco a possibilidade financeira de engajar-se na produção desse tipo de fotografia "artística". No âmbito das artes, as condições materiais não lhe reservariam senão o mais baixo escalão da produção, o desprestigiado ofício de fotógrafo documental, que, com alguma sorte e severa agudeza de visão mercadológica e compreensão das necessidades do segmento no qual tentava se inserir, the possibilitaria abastecer parte do mercado de arte do qual ele também houvera sido excluído, rendendo-lhe alguns trocados (ele cobraria por volta de um franco por documento produzido; um franco e vinte e cinco cêntimos se precisasse pegar um trem para fotografar o motivo escolhido pelo cliente). Materializavamse, em sua existência cotidiana, os papéis terciários que ocupara no teatro e na pintura.

"Fotografias são documentos que têm uma tarefa específica a cumprir", afirmaria Baudelaire no ensaio $O$ público moderno e a fotografia. Com sóbrias e pessimistas palavras, ele anunciaria a nova técnica a seus leitores:

"Nesses dias deploráveis, uma nova indústria surgiu, que muito contribuiu para confirmar a tolice em sua fé [...] de que a arte é e não pode deixar de ser a reprodução exata da

${ }_{19}$ Citado em LEROY, J. Atget - magicien du vieux Paris. op. cit. Em determinado momento, Demarchy lamenta publicamente que "técnicas interpretativas" como a croma bicromatada não tenham adeptos suficientes para elevar o nível da produção fotográfica francesa, sendo esta, segundo ele, a principal causa da "estagnação" da fotografia pictorialista na França no início do século XX. A este respeito, ver POIVERT, M. Les relations internationales du pictorialisme au tournant du siècle (1898 - 1902). In Le Salon de Photographie - Les écoles pictorialistes en Europe et aux Etats-Unis vers 1900. Paris: Musée Rodin, 1993. 
natureza. [...] Um deus vingativo realizou os desejos dessa multidão. Daguerre foi seu Messias [...]."20

Baudelaire entende que existiriam essencialmente dois modos de percepção da realidade: aquele que "julga sucessiva e analiticamente" e outro, distinto deste, que privilegia o sentir "de imediato, simultânea e sinteticamente". Estas maneiras de percepção são, para Baudelaire, historicamente construídas. Assim, o modo de perceber a realidade que definiu como "construído de maneira sucessiva e analítica" atenderia à perpetuação dos interesses específicos da classe burguesa dominante de sua época. Este modo privilegia o entendimento "racional", a capacidade quantificadora da mente humana e o empobrecimento da qualidade da percepção. $O$ artista que se vale de tal estratégia, reproduzindo "fielmente" a realidade, contribui, segundo Baudelaire, para a manutenção e ratificação das instituições e status quo burgueses. A fotografia, por sua vontade utópica de copiar a realidade, seria vista como uma outra forma de reprodução desses mesmos modos quantificadores, ou seja, ratificaria uma realidade que é organizada através da lógica da quantidade e da eficácia administrativa e tecnológica. Em suma, consistia em uma nova forma que reafirmava as velhas maneiras de percepção. Não deveria, portanto, almejar condição superior a de modesta "serva" (o termo é de Baudelaire) das artes e ciências, como as técnicas de impressão ou de estenografia. É verdade, no entanto, que o crítico e poeta

"receia menos a fotografia em si mesma do que o uso totalmente iconoclasta que o público moderno se apresta a fazer dela. Aqueles que se recusam a saudá-la como novo penhor de progresso temem a fotografia enquanto arma nas mãos do Burguês, arma por cujo intermédio se procura consolidar o reino do bom senso, excluindo toda a idéia de belo, de fuga ao naturalismo e até mesmo de imaginação,

${ }^{20}$ Cf. BAUDELAIRE, C. CEuvres Complètes. op. cit. p. 748. 
constrangendo o artista ao papel de simples copista da natureza." 21

O outro modo de percepção, aquele que é sentido "de imediato, simultâneo e sinteticamente" está ligado ao despertar dos sentidos que foram enterrados sob o pragmatismo burguês, que propositadamente aguçou a primeira maneira de perceber, desprivilegiando a segunda. Esta maneira de percepção ultrapassa as formas quantitativas, pois se utiliza de símbolos que falam aos sentidos. Através do conceito de "correspondance" Baudelaire busca a correspondência entre os símbolos, com um apelo aos sentidos de forma a redespertá-los na busca de um significado. Por conseguinte, a mera cópia da realidade significava para Baudelaire copiar a superfície visível dos fatos em conformidade com o mundo burguês, uma vez que esta maneira de percepção da realidade havia sido historicamente construída e atendia a interesses bastante específicos. O papel do verdadeiro artista consistia, pois, em pulverizar a superfície dos fatos em seu valor de face para, segundo novos arranjos e configurações, reconstruí-los num plano sensorialmente mais aguçado. ${ }^{22}$

Grosso modo, chamar uma fotografia de documento significava, assim, admitir seu caráter de "cópia" do mundo visível e, no limite classificá-la como uma "produção inferior" nos termos acima descritos, ao menos como se compreendia a produção artístico-fotográfica até a época de Atget, marcadamente dividida entre fotografia "documental" e fotografia "artística" (não seria assim até nossos dias?). Além de fotografias, outras fontes poderiam servir como documento para artistas-pintores ou fotógrafos-pictorialistas: motivos ornamentais como tapeçarias ou vitrais, elementos produzidos por culturas estrangeiras "exóticas" como máscaras africanas e mesmo gravuras populares, caricaturas, imagens do vestuário da última moda ou croquis de mobiliário. Toda esta "matéria prima" utilizada na confecção da "grande obra" era, em princípio, uma produção visual

${ }^{21}$ Cf. OEHLER, D. O repúdio à fotografia. In Terrenos vulcânicos. op. cit. pp. $219-220$.

22 Cf. OEHLER, D. O Velho Mundo Desce aos Infernos. Auto-Análise da Modernidade Após o Trauma de Junho de 1848 em Paris. São Paulo: Companhia das Letras, 1999. 
considerada inferior que, embora vital, não deveria ultrapassar as rígidas fronteiras de subordinação na hierarquia da produção artística (pensemos novamente na relação estabelecida por Baudelaire entre a produção artística que "serve" e aquela que "é servida", de caráter marcadamente senhorial). Segundo aqueles que delas se beneficiavam, faltavam-Ihes, afinal, "precisão artística", "rigor intelectual" e "expressão de sentimento". Na definição oficial do conceito de documento, elaborada por ocasião do Quinto Congresso Internacional de Fotografia em Bruxelas em 1910, lia-se:

\begin{abstract}
"Uma imagem documental deve estar apta a ser utilizada para estudos de diversos tipos, daí a necessidade de incluir o maior número possível de detalhes. Qualquer imagem pode, a qualquer momento, servir à investigação científica. Nada deve ser negligenciado: a beleza da fotografia é secundária neste caso; é suficiente que a imagem seja clara, plena de detalhes e cuidadosamente tratada para resistir tanto quanto possível à ação destrutiva do tempo."23
\end{abstract}

Noutros termos, um documento não passa de um sketch preparatório que deve fornecer uma vaga idéia do produto final. Não se destinava à exposição pública e portanto jamais frequentaria o circuito das exibições, galerias e salões. Confinado à zona periférica da produção artística, equivaleria, nos termos da pintura tradicional, ao papel desempenhado pelo estudo (em suas diversas etapas e variações: o croquis, o esquisse, o étude e o ébauche) ou, no desenho, ao desenho técnico (funcionando como ferramenta especializada que descreve os elementos posteriormente utilizados por saberes mais "nobres" como a arquitetura, a engenharia ou o que se convencionaria chamar posteriormente de design). A beleza deste documento é secundária em relação a seu uso e não possui uma forma final prescrita ou definida, em conformidade com uma

${ }^{23}$ Cf. NESBIT, M. Atget's Seven Albums. New Haven e Londres: Yale University Press, 1992, p. 16. 
determinada tradição que o precede (distintamente da pintura). Ao contrário, sua forma toma corpo durante seu processo de execução e segundo as necessidades ou condições impostas pelo objeto ou assunto a que se reportará; o documento não é auto-suficiente e sua determinação fundamental é o tipo de trabalho que necessita desempenhar no sistema de produção no qual se insere - e ao qual se encontra subordinado. Ele é a base desse sistema e encontra-se inserido numa relação de troca: deve executar, da melhor maneira possível, um trabalho, a saber, a tarefa de fornecer a informação desejada de modo objetivo e imparcial a um certo espectador ou usuário que, se bem equipado, estará apto a decodificar a informação sem maiores problemas - o documento deveria ser, assim, além de preciso, "silencioso": a expressão de uma voz ou ponto de vista não the eram facultados. A qualidade do trabalho executado será tanto melhor quanto maior o domínio e perfeição da técnica daquele que o produziu, pois 0 "bem servir" significa, neste caso, precisamente fornecer a informação desejada poupando esforços, ou, se preferirmos, trabalho, no ato de sua decodificação.

A partir do século XIX o documento cresce em importância também na elaboração de provas históricas e científicas, expressando conhecimento ou tornando-se um caminho para atingi-lo. É, contudo, ainda um conhecimento utilizado para produzir um outro conhecimento, que se pretende "superior", ou, por outra, "em estágio mais avançado". O documento não é, em si, uma fonte de autoridade com autonomia; expressa-se do ponto de vista do subordinado. Permite certo diálogo ou colaboração entre as diversas esferas, porém o fim último é sempre a formulação de um determinado tipo de conhecimento que mantém intactas as relações de subordinação no âmbito de sua produção, circulação e utilização. Não poderia, nestes termos, propiciar ou almejar a criação de um conhecimento como um corpo coeso expresso em uma Obra com um determinado Estilo, uma vez que os imperativos da produção de documentação impunham a regra da fragmentação (com a divisão das imagens em grupos, sub-grupos e categorias) e do mercado (os documentos deveriam ser essencialmente mercadorias vendáveis), atendendo por sua vez às 
demandas das diversas áreas da produção artística, histórica ou científica dos vários saberes, as chamadas connaissances, que não buscavam estabelecer elos ou paralelos entre as distintas "famílias" de conhecimento.

Para maximizar suas chances de inserção no mercado, no limite para sua própria sobrevivência - e aquela dos que o produziam - o documento não deveria restringir-se a apenas uma destas "famílias". Era desejável que contivesse informação suficientemente variada para assim circular numa multiplicidade de espaços, técnico, histórico e científico, expondo-se e vendendo-se. Daí a importância capital das escolhas de temas ou assuntos feitas por aqueles que o produziam, bem como do domínio da técnica para representá-los que, como vimos, quando corretamente aplicada, propicia o alto grau de legibilidade desejada, marca de sua qualidade. É nestes termos que os documentos declaravam seu valor de uso. Quanto mais competentemente executados, maiores suas possibilidades de troca. Portanto, existiam e operavam como um bem como outro qualquer ${ }^{24}$. Eram, em suma, na forma de uma mercadoria, o passo inicial que possibilitaria a criação de outras mercadorias. Por esta via, o olhar daquele que fabrica o documento não é o olhar do prazer. $O$ artesão ou trabalhador executa, com a maestria de quem domina as técnicas para melhor escolher, isolar, delimitar e representar os motivos escolhidos, a necessária "limpeza" na imagem documental que, após atingir a máxima legibilidade, trazendo a primeiro plano a informação desejada, insere-se no circuito da circulação e do comércio. Trata-se, desde o momento de sua concepção, de imagens pautadas por uma operação de subtração: no limite, retratam um objeto mas também revelam uma ausência ou falta, pois pretendem objetivar o sujeito retratado (ao contrário dos artistas, que a partir destas imagens o subjetivariam). Sob a égide de uma rígida hierarquia da visão, o olhar do documento revela-se o olhar do Trabalho. Atget rapidamente aprenderia esta lição.

${ }^{24}$ Cf. NESBIT, M. Atget's Seven Albums. op. cit. 
"Um arquiteto poderia utilizar-se da fotografia que Atget fizera do portal de St. Nicolas du Chardonnet, por exemplo, para buscar as linhas de estilo, os detalhes da construção, o jogo de proporções, e assim por diante. Todo este conhecimento destinava-se a ser aplicado aos negócios ou à arquitetura; era isto que o olhar técnico apreendia. E, no entanto, esta imagem de Atget não era a única disponível: pertencia a uma categoria de imagens semelhantes daquela porta de igreja, a começar pelo desenho original de Charles Lebrun e a gravura de César Daly, um dos motifs historiques incluídos em um portfólio em 1869. Atget estava, de fato, apenas repetindo o motivo em 1900, embora não tivesse o equipamento necessário para abarcar o átrio: ao expor a placa de vidro considerando o grau de luminosidade da porta, terminou por construir um documento que retratava uma rua por demais clara. Mas ainda assim esta fotografia exibe os requisitos necessários para ser considerada um documento para arquitetos: a câmera foi fixada paralelamente ao assunto, que preenche toda a imagem. Não há detalhes irrelevantes. A maior claridade possível foi atingida com a luz que recai sobre o objeto da maneira mais oblíqua possível por um dos lados, criando sombras que oferecem máximo relevo. Os limites enquadravam o assunto de tal modo que os fotógrafos de 'arte' recusavam-se a associar suas obras a este tipo de imagem, argumentando que o trabalho carecia de idéias independentes, ou pior ainda, de qualquer idéia. Atget não entrava no debate e obedecia às convenções tanto quanto podia, calculando possíveis margens para desvios considerados como aceitáveis, por exemplo, deixar de fora um pórtico. Como resultado, o portal de Atget é representado em uma fotografia de arquitetura altamente convencional e 
literal, comparável às linhas do desenho mecânico. O documento continha todo o necessário para servir ao arquiteto do modo mais prático. Áreas distintas não se mesclavam e o assunto não se encontrava perdido. Derivavase, da visão prática, uma outra ordem de representação." 25

Quando Atget anuncia na pequena placa que fixa à porta de seu apartamento que executa "documentos para artistas", o fotógrafo já é um trabalhador consciente de que ele e suas fotografias se inserem neste sistema de relações ${ }^{26}$. Ao ser convidado pelo já famoso artista e fotógrafo americano Man Ray a publicar na capa da prestigiada revista La Révolution Surrealiste a imagem que intitulara "Eclipse, abril de 1912" (fotografia de uma pequena multidão no centro de Paris que olha para o céu buscando ver um eclipse), só não declinou o convite pelo dinheiro que receberia. Os termos das negociações são incertos, porém teria insistido de modo abrupto com o artista: "Não ponham meu nome na imagem! O que faço é documento para artistas!"27 (a fotografia seria publicada na edição de 15 de junho de 1926 sob o título "Les dernières conversions"). Embora soubesse da existência das vanguardas e das outras formas de produção fotográfica, sobretudo o pictorialismo, Atget era plenamente consciente do papel e do lugar social que ocupava fora do circuito artístico.

Por vezes chegavam-Ihe compradores em busca de imagens ou encomendas. $O$ mais frequente, no entanto, era percorrer a cidade tentando vender imagens

${ }^{25}$ Cf. NESBIT, M. Atget's Seven Albums. op. cit. p. 18.

26 Cabe, portanto, salientar que todas as considerações comerciais e estéticas feitas pelo fotógrafo de fato desautorizam interpretações que insistam nos aspectos "melancólicos", "nostálgicos" ou "românticos" como estruturas fundantes de suas imagens. Alguns exemplos deste tipo de interpretação da obra do artista podem ser encontrados em BUISINE, A. Eugène Atget ou la mélancolie en photographie. Nîmes: Éditions Jacqueline Chambon, 1994. Posturas mais "radicais" que não admitem qualquer interpretação "fixa" da obra do fotógrafo (que tenderiam a reduzir seu objeto de estudo e que, no caso de Atget, não se prestaria a tanto) não são raras: "Todos buscam fazer da obra de Atget a expressão de uma certa ideologia. Cada qual pretende encontrar o homem por detrás do mito. Mas devemos nos resignar ao fato de que 0 homem é inapreensível. As evidências deixam intacto o mistério. Cf. BEAUMONT-MAILLET, L. Atget Paris. op. cit. p. 18.

${ }^{27}$ Cf. NESBIT, M. Atget's Seven Albums. op. cit. p. 1. 
previamente concebidas, a partir da experiência que adquirira da necessidade expressa por seu público: estudos de figuras humanas (anatomia, vestuário, tipos urbanos, gestos, ocupações ou métiers) e de coisas ou lugares (árvores, flores e plantas de diferentes espécies e em diferentes estações do ano, paisagens, parques, ruas, lojas, edifícios, fachadas, elementos arquitetônicos ou decorativos, mobiliário urbano e estudos que auxiliassem na criação de "efeitos pictóricos", incluindo a representação da luz e do ar em paisagens ou refletidos na água). O fotógrafo mantinha um caderno, seu répertoire, com informações sobre nomes e endereços de seus compradores mais assíduos: uma rede de pintores (que, para sobreviverem, frequentemente também trabalhavam como decoradores de interiores), ilustradores, gravadores, escultores, arquitetos e profissionais da indústria da construção civil (que viam no documento fotográfico a possibilidade de imitar ou reconstruir estilos arquitetônicos passados, sobretudo o clássico, sempre em voga, sinônimo de tradição e civilização francesas mas, não menos importante, de grandes negócios), decoradores e cenaristas de mansões particulares, de teatro e de cinema (ávidos consumidores que mantinham verdadeiras bibliotecas de imagens para criação de cenários e décor para as residências grã-finas, a indústria do entretenimento e do showbiz), amantes da "velha" Paris (antiquários profissionais ou abastados amadores, para quem as imagens significavam essencialmente a reconstituição de um passado longínquo ou nostálgico, uma coleção de peças antigas num acervo de caráter museológico), bibliotecas de todos os tipos, editoras (que publicariam as imagens de Atget em livros e revistas ou confeccionariam cartões postais sobre tudo que parecesse "pitoresco" na cidade de Paris) e marchands. Braque e Picasso estavam entre seus clientes (embora seus nomes não constassem no répertoire), assim como Derain, Foujita, Vlaminck, Utrillo e outros artistas que frequentavam os Salões. Clientes de menor fama, mas não menos importantes, também eram frequentes compradores, como o chaveiro Jules Bricard, um nome listado em quatro páginas diferentes do répertoire, com indicações precisas de endereço, horários para atendimento, pranchas vistas e consideradas pelo 
cliente e suas futuras encomendas. ${ }^{28}$ Como Bricard, outros petits métiers frequentavam o répertoire de Atget, a quem importância não era negada, por exemplo, tapeceiros, vidraceiros e bordadores. Ele tinha contato com todo tipo de gente, do presidente da Sociedade dos Artistas Franceses e membro da Comissão Municipal da Velha Paris, Edouard Detaille e o banqueiro J. P. Morgan (pilares das vendas do fotógrafo) à gente simples das ruas.

Constituindo-se de uma clientela que Ihe permitia vender imagens para uso público e privado, organizou seu trabalho como the fora solicitado (ou imposto), por temas, categorias e sub-categorias. A velha Paris ou A arte na velha Paris [Vieux Paris ou L'art dans le Vieux Paris] fora iniciada em 1897 e incluía monumentos, cenas pitorescas de rua, arquitetura eclesiástica, residencial e institucional, detalhes arquiteturais, grades, insígnias, estruturas espaciais e suas decorações e interiores. Arredores de Paris [Environs de Paris] também era dedicada a monumentos na periferia da cidade. Topografia da velha Paris [Topographie du Vieux Paris] iniciou-se em 1906 e era na verdade uma subdivisão da Paris pitoresca. Consistia na re-atualização das imagens feitas por seu predecessor, Charles Marville, que documentara, de um ponto de vista bastante distinto, as contínuas reformas vividas pela cidade sob Haussmann. A série termina em 1919. Paris pitoresca [Paris Pittoresque] foi iniciada em 1897 e é composta de fotografias da vida urbana, de mercados, dos pequenos ofícios, veículos antigos, quiosques, pequenas lojas [échoppes], fachadas de lojas, bares e cafés, mercadorias espalhadas, mercados, o circo e atrações de feiras. Atget incluiria nesta série o acompanhamento e o desenrolar das reformas urbanas nos inúmeros canteiros de demolições, sobretudo aqueles da Rive Gauche. Esta parece ter sido a série na qual Atget reflete de maneira mais radical sobre o processo de modernização pelo qual passava Paris e a vida da cidade sob a modernidade. $O$ fotógrafo executa estas imagens até meados de 1900, retomando o trabalho a partir de 1910. Finalmente Paisagem -

${ }^{28}$ Cf. NESBIT, M. Atget's Seven Albums. op. cit. 
documentos diversos [Paysage - documents divers] inicia-se por volta de 1892 e engloba todas as imagens que não pertenciam às categorias anteriores.

\begin{abstract}
"Por vezes Atget trabalhava por encomenda, mas normalmente arriscava-se no trabalho por conta própria, frequentemente com setores específicos de clientes. Estes setores se definiam para Atget. Os pintores normalmente 0 indicavam para outros pintores e os membros da indústria da construção civil indicavam-se uns aos outros. Com os cenaristas e os amantes da 'velha Paris' tinha lugar a mesma atitude de 'clube fechado'. Isto teria encorajado Atget a pensar nos termos das várias profissões e organizar seus documentos de acordo com as funções que desempenhariam. Conforme fazia seus negócios, foi levado a pensar nos termos de categorias. Eram categorias da visão prática." ${ }^{29}$
\end{abstract}

A partir de 1899 Atget detecta um filão de mercado que passa a explorar: a produção de imagens que retratassem as cenas quotidianas, os hábitos e os costumes (les mœurs) dos trabalhadores que exerciam pequenos ofícios na cidade de Paris. As imagens, utilizadas por diversos profissionais, deveriam naturalmente ser executadas segundo as diretrizes encerradas na ideia de documento. Portanto, o fotógrafo tratará este assunto como trataria qualquer outro, ou seja, como uma "família" de conhecimento, uma connaissance que deveria ser visualmente apreendida a partir de certos códigos e regras visuais prescritas por imperativos mercadológicos. Para tanto, fragmenta e categoriza os assuntos, reduzindo-os imageticamente a seus elementos ou componentes essenciais para, através do domínio técnico que adquirira, proporcionar a seus

${ }^{29}$ Cf. NESBIT, M. Atget's Seven Albums. op. cit. p. 26. 
clientes o produto final desejado (lembremo-nos que por não gozarem de status artístico, nenhum cliente buscaria nestas imagens marcas de estilo "individual" ou "artístico", tampouco deleite estético; sua livre contemplação era, mais que indesejável, sinônimo de fracasso comercial). Como não se tratava de um trabalho por encomenda, o fotógrafo procura colher a maior variedade possível de personagens e situações, com vistas a aumentar suas possibilidades de negócios. Ele busca, assim, representar uma multiplicidade de tipos, dos extratos mais elevados, os comerciantes e os artesãos, aos mais inferiores, personificados na figura do catador de lixo ou trapeiro, o chiffonnier, rebotalho da sociedade. No pequeno conjunto de imagens selecionadas para as considerações que seguem, fotografias tomadas num mercado de rua e em seus arredores, entre a Place Saint-Médard e a rua Mouffetard, no quinto bairro da cidade, produzidas entre 1898 e 1901 (portanto no início do projeto que, como vimos, seria retomado a partir de 1910), as questões ligadas à vida na modernidade já aparecem plenamente configuradas. Mas o que tais clichês fotográficos revelam sobre as condições de vida e trabalho dos retratados nesta Paris fin de siècle?

A imagem que inicia esta série retrata a praça à distância em ângulo frontal e data de 1898 (Figura 12). Atget era extremamente metódico quanto aos procedimentos utilizados pois sabia que disso dependeria não apenas a qualidade de suas imagens como também a possibilidade de executar o maior número possível de fotografias a cada saída fotográfica (como vimos, as oportunidades de ganho jamais seriam negligenciadas!). Ao produzir uma série de imagens ${ }^{30}$, geralmente iniciava o trabalho escolhendo um ponto de vista que permitisse a apreensão global do assunto e do espaço representados, buscando estruturá-los com a máxima iluminação possível para que todos os elementos e detalhes da cena fossem registrados pela placa de vidro e papel sensibilizado.

\footnotetext{
30 Não raro, Atget fotografava várias séries ao mesmo tempo e preferia trabalhar deste modo pois poderia comercializar as fotografias individualmente ou propor ao cliente a venda de toda(s) a(s) série(s), composta(s) de duas ou mais imagens, segundo o tema e suas possibilidades de execução.
} 
Como seu equipamento era antigo e bastante pesado (adquirira uma velha câmera de grande formato num mercado de pulgas da periferia da cidade formando, aos poucos, sua coleção de lentes de segunda-mão compradas aqui e acolá), era fundamental que poupasse esforços desnecessários ${ }^{31}$. Deste modo, o fotógrafo tomava as imagens que julgava adequadas a partir do ponto de vista escolhido sem praticamente mover a câmera, não sem antes avaliar o posicionamento exato para o equipamento fotográfico, fazendo pequenos movimentos e as necessárias alterações de lentes e placas que permitiriam as variações desejadas ${ }^{32}$. Somente então avançaria em direção ao objeto, movendo-se segundo suas intenções, possibilidades e restrições.

A imagem que precede este avanço nos revela, em visão panorâmica, a praça banhada pela luz matinal. Vemos, à direita, parte da fachada de uma construção medieval, a igreja Saint-Médard. No centro, a fachada de um edifício moderno recoberto por uma miríade de propagandas e anúncios de tamanhos diversos. Naqueles mais visíveis lê-se "Pharmacie commerciale" [farmácia comercial], "Au Bon Marché" (referência à primeira e mais elegante loja de departamentos da cidade) e, acima deste, um anúncio que contém em letras garrafais a palavra

31 O equipamento completo do fotógrafo era composto de uma câmera de grande formato ( $18 \mathrm{x}$ 24) com fole, os chassis nos quais as placas de vidro eram introduzidas, a capa negra que cobria o equipamento no ato de fotografar, evitando possível entrada de luz, o conjunto de lentes e o tripé de madeira. Ao todo, Atget carregava cerca de vinte quilos todos os dias ao redor da cidade. Ele jamais utilizou-se das películas fotográficas plásticas e flexíveis, disponíveis no mercado a partir do final do século XIX. Uma vez encontrados os suportes adequados para execução de suas imagens, os papéis sensibilizados e as placas de vidro, Atget os explora ao máximo para obter os efeitos desejados. "A quase totalidade de suas fotografias são tiragens albuminadas. O papel era vendido preparado, embebido [trempé] na clara de ovo batida e salgada, que o fotógrafo punha em contato com um banho de nitrato de prata. O papel sensibilizado, assim preparado e seco, era posto em um chassis com o negativo sobre a placa de vidro do clichê e exposto à luz do sol até a obtenção de uma imagem, depois fixada e 'virada' com um sal de ouro. Do processo resultavam imagens muito nítidas [piquées], verdadeiramente distantes do flou pictorialista da época. As tiragens assim obtidas eram bastante estáveis mas a espessura final do papel e sua tendência a se enrolar levaram Atget (e outros) a colar suas fotografias em cartões, prática desastrosa pois estes eram ácidos e descoloriam as provas. Por outro lado, a albumina, que não podia se enrolar, craquelava. Atget decidiu, na sequência, pelas tiragens em aristotipo em papel de citrato [des aristotypes au papier citrate], vendido já sensibilizado e mais estável. Infelizmente eram comumente mal fixados ou lavados e manchas irremediáveis alteraram um grande número de imagens." Cf. MAILLET, L. B. Atget Paris. op. cit. p. 15.

${ }^{32}$ Cf. HARRIS, D. Eugène Atget - Itinéraires parisiens. Paris: Paris Musées et Éditions du Patrimoine, 1999. 
"deuil" ["luto", em francês]. No maior lemos "Grand bazar universel - Maison L. Demogé - 13, 15 \& 19 - Ave. Des Gobelins - Maison recommendée pour son grand assortiment et vendant le meilleur marché de Paris" [grande bazar universal - Casa L. Demogé - 13, 15 \& 19 (indicação de suas filiais nestes três bairros, designados por seus números) - loja recomendada por sua enorme variedade e pelos melhores preços de Paris; as palavras "bazar" e "universel" aparecem em letras gigantes]. Abaixo deste: "Vins et dégustation" [vinho e degustação]. À esquerda, outros edifícios também recobertos por propagandas: "Chocolat Vinay", "Boulangerie-pâtisserie", parte da palavra "ventes" [vendas] seguida por "en gros et en détail" [no atacado e no varejo], a palavra "connaissances", [que além de "conhecimento" e "saber" pode também significar "compreensão", "consciência" e "lucidez"] e outros tantos anúncios ilegíveis. No edifício à esquerda em primeiro plano, a bandeira francesa está hasteada. Por toda a praça circulam pedestres, negociantes e fregueses do mercado. Uma figura humana é representada pela metade no canto esquerdo inferior da imagem, como um borrão que inopinadamente abandona a cena fotografada. A grande porção de rua representada na parte inferior do primeiro plano e a ausência de um ponto de fuga (qualquer tentativa nestes termos depara imediatamente com a "barreira" de propagandas no centro da imagem) convida, ou melhor, impele o espectador, que neste momento ainda observa de longe os acontecimentos, a adentrar o espaço retratado, onde cada detalhe foi cuidadosamente registrado. A representação da cena nestes termos não comporta dúvidas quanto ao espaço que será investigado: o cenário urbano e as personagens que (ainda) guardam (alguma) característica da velha Paris.

A próxima imagem difere da primeira no enquadramento, com a supressão da porção de rua e céu presentes na imagem anterior (Figura 13). A exclusão destes elementos visuais motiva, pela "justaposição" de planos e "decupagem" no tempo da narração, um "salto" na narrativa proposta pelo fotógrafo, um hiato ou elipse espacial e temporal, que embora não desoriente por completo seu espectador (não o suficiente para privá-lo totalmente do sentido de tempo ou de 
espaço proposto na primeira imagem), marca sua presença, explicita-se como procedimento técnico e chama atenção para si ao aproximar, subitamente, o observador do objeto, instalando-o de modo abrupto no epicentro da cena e de seus acontecimentos. Encontramo-nos agora "fisicamente" mais próximos dos trabalhadores: no canto inferior direito da imagem, deparamos com a enorme carroça de duas vendedoras de frutas e legumes frescos [marchandes des quatre saisons] e, atrás delas, uma criança. Eles olham fixamente para a câmera, encarando o fotógrafo, e por conseguinte o observador, cientes tanto de sua presença como do fato de que se fazem fotografar e são observadas (ou "estudadas"). Por detrás deles, no fundo à direita, parte da antiga igreja, velhas casas e uma luminária a gás. No centro da fotografia, uma pequena multidão circula pelo espaço, comercializando seus produtos, fazendo suas compras ou simplesmente caminhando. Dentre todos, seis destas personagens olham em direção à câmera, ratificando a presença do equipamento e do profissional que o manipula. Acima de todos, e também no canto superior esquerdo, parte das enormes propagandas descritas anteriormente apodera-se do espaço restante na cena.

Rumo à representação dos pequenos ofícios em suas particularidades, uma última imagem os relaciona mais diretamente ao espaço da praça (Figura 14). Igualmente um "corte" espaço-temporal: embora sempre à altura do olho do observador, a câmera moveu-se, recuou no espaço por alguns instantes e constituiu um novo núcleo temático e narrativo na nova imagem que se nos apresenta. Fomos mais uma vez arremessados a outra parte. Ainda na praça, afastamo-nos das propagandas anteriormente muito próximas, vislumbrando apenas parte do letreiro "Vins et dégustation". Abaixo deste, ao fundo, vemos uma carroça e seus cavalos, retratadas com menor qualidade focal se comparada às figuras no centro da fotografia, uma velha florista que oferece suas flores a uma possível compradora. Entre as duas, ligeiramente atrás, um policial uniformizado patrulha o mercado. Uma grande porção da rua é de novo representada, agora à direita e em plano intermediário. A pequena multidão da 
imagem anterior não mais se faz presente. Foi substituída por uns poucos passantes que ocupam o espaço à esquerda do trio. Nós, até este momento mais observadores que agentes, nos encontramos de frente para esta cena, cujo foco recai nas três personagens centralizadas. No canto direito da fotografia, parte do corpo de uma senhora com um cesto de frutas ou verduras, possivelmente uma vendedora. Não vemos seu rosto. Ela caminha para "fora" da imagem (não seria de todo implausível pensarmos que se dirige rumo à câmera), sugerindo a continuação da cena no extra-quadro (Degas; Manet).

Já bem mais próximo das figuras representadas, o espectador defronta-se neste momento com uma sequência de cenas diversas, cada qual registrada por uma fotografia, que privilegiará a representação dos pequenos ofícios em suas particularidades, isolando-os do espaço que ocupam, sozinhos ou acompanhados em suas interações com clientes ou parceiros. Vale notar que registrar suas "particularidades" significa, para Atget, a descrição da indumentária, das poses, dos gestos, dos apetrechos, das mercadorias comercializadas, das ferramentas de trabalho, mas não propriamente dos traços físicos individuais das personagens - o fotógrafo não utilizou jamais o close para retratar um petit métier. Estas imagens são quase todas muito semelhantes: tomadas sempre de corpo todo, vemos no centro, em primeiro plano, as "personagens principais", ao seu lado, algum "figurante" e, no fundo, parte do cenário anteriormente descrito, agora enormemente desfocado quando comparado à nitidez atribuída às personagens. A luminosidade é relativamente uniforme: circunda as personagens mas não as determina ou as define (uma economia da luz profundamente distinta do uso corrente do chiaroscuro divinizante ou caravaggesco comum tanto na pintura tradicional quanto na fotografia pictorialista).

De modo análogo à primeira imagem, o encurtamento da profundidade significa, também aqui, encurtamento do ponto de vista. Tal procedimento, juntamente 
com a posição da câmera à altura do olho do fotógrafo ${ }^{33}$, que revela o ponto de vista como aquele do passante diante da modernização em curso, instala o observador na cena retratada. O espectador continua a exercitar-se nos abruptos deslocamentos espaço-temporais, porém agora, fisicamente alojado no interior das imagens e ao lado dos trabalhadores fotografados, confronta-se de modo ainda mais direto com 0 assunto das fotografias. Atget radicaliza 0 procedimento: o espaço desfocado, com total rejeição da representação perspéctica, impossibilita a fuga do olhar do observador ao mesmo tempo em que o aprisiona e o sufoca no exíguo espaço ocupado pelas figuras (índice do avanço de Atget ao compararmos estas imagens com "O semeador", de Millet), envoltas numa densa atmosfera dominada por uma névoa, vapor, ou por outra, um miasma ${ }^{34}$. Ao ocuparem tal posição, fotógrafo e observador tomam seus lugares, no limite tornam-se um "igual", ou seja, um trabalhador como eles. $O$ efeito de estranhamento e desorientação é incrementado com o passar das imagens que vemos, como se percorrêssemos às pressas e desordenadamente um espaço que se nos apresenta repentinamente como inóspito e desconhecido. Não estávamos numa praça conhecida observando o trabalho de

\footnotetext{
${ }^{33}$ Lembremo-nos novamente que Atget era consciente das poucas possibilidades de manobra disponíveis para a confecção de seus documentos. Perspectivas por demais pronunciadas, distorções de formas, ângulos escarpados ou quaisquer outros procedimentos percebidos como por demais anti-convencionais simplesmente não poderiam constar em seu repertório (distintamente daqueles utilizados na pintura por um Gustave Caillebotte, ou, na fotografia, por um Émile Zola, que também fotografava em suas horas livres e produziu grande número de clichês fotográficos. Refiro-me aqui sobretudo às imagens produzidas pelo escritor retratando a Exposição Universal de Paris em 1900). Mas na aparente "naturalidade" das imagens produzidas por um Atget que ofereceria a "Verdade" do mundo visível esconde-se, como veremos, a experiência de um tipo bastante específico de vivência. Para maiores considerações e referências iconográficas sobre a produção pictórica de Caillebotte, ver FONSMARK, A. -B. [et alii]. Gustave Caillebotte. Ostfildern: Hatje Cantz Verlag, 2008. Quanto à produção fotográfica de Zola, ver ZOLA, F. E. Zola Photographer. Nova York: Seaver Books, 1988.

34 Um pouco antes, Georges Seurat já buscara expressar as relações entre teatro, espetáculo e política na produção de desenhos feitos com lápis conté em papel michallet. Os meios e as técnicas escolhidas pelo pintor favoreceriam a criação de efeitos semelhantes àqueles obtidos fotograficamente por Atget, a saber, o abandono do contorno demarcado das figuras (apregoado pelas escolas de belas artes e oposto à idéia baudelairiana de modernidade) e a utilização da gradação tonal que "dissolvia" o assunto no ambiente em que se encontrava. A utilização de linhas que se assemelham a rabiscos aleatórios, ao mesmo tempo que estruturadas a partir do enorme controle e domínio da técnica do desenho, apontam para idéia de desmistificação da noção de genialidade autoral e para a necessidade da expansão das fronteiras e possibilidades de democratização da produção artística. Para referência à obra de Seurat, ver HAUPTMAN, J. Georges Seurat - The Drawings. Nova York: The Museum of Modern Art, 2007.
} 
uma velha florista? Quem são essas "novas" personagens, homens, mulheres e crianças trabalhadores, que se apresentam, como num desfile diante de nós, neste "novo" espaço? O que vendem agora? Se cada fotografia sugere, propõe ou obriga identificação com a personagem ou cena retratada numa contínua sucessão de imagens, cabe a pergunta: quem somos nós agora e o que pretendemos vender desta vez nesta atmosfera delirante e insalubre que reprime, intoxica e asfixia, de constantes e pseudo-mudanças, num salve-se quem puder generalizado, assumindo papéis intercambiáveis que serão pronta e incessantemente descartados e retomados, como identidades sucedâneas incapazes de se fixarem? Imersos no universo do trabalho alienado, somos nós o objeto de escrutínio. As fotografias de Atget articulam uma operação mental que compele o espectador a se entender ele também como um vendedor de sua força de trabalho naquele mercado. É a exposição radical e distanciada deste processo que permite ao espectador alcançar a consciência amplificada de seu lugar social, ou, se preferirmos, de sua classe. O efeito desejado parece ter sido plenamente atingido: a metáfora explícita para a prostituição geral do trabalhador que leva sua força de trabalho, despersonalizada e abstrata, àquele mercado como qualquer outro bem ali à venda nos tornou conscientes de que somos o que as fotografias nos fazem ver, o vendedor que se vende.

As imagens continuam sua sequência e as sensações de convulsão, frenesi e descontinuidade (estrutural) não cessam. O vendedor ambulante de cestas conversa com uma possível cliente (Figura 15). Um homem e uma mulher negociam o preço dos legumes à venda (Figura 16). Uma senhora oferece suas flores ao rapaz (Figura 17). O comerciante de alcachofras isola-se atrás das grades num canto da praça (Figura 18). O vendedor de guarda-chuvas ergue seus produtos como se os oferecesse a um suposto cliente no exterior das fronteiras da imagem (Figura 19). Duas mulheres, uma delas com uma criança que dorme em seus braços, agacham-se no meio-fio esperando os clientes que virão comprar seus produtos (Figura 20). Uma criança nos estende a mão, 
esconde o olhar e nos oferece um maço de ervas (Figura 21). Um chiffonnier conduz uma carroça abarrotada de sacos e lixo (Figura 22).

Recapitulando: compreender a utilização e atribuição de foco seletivo nas imagens de Atget significa a compreensão da essência de sua produção iconográfica. Num primeiro momento, ao concentrar-se no "cenário" da vida urbana, a praça e suas ambiguidades visuais (o antigo - a igreja -, e o novo os prédios -, a colonização do espaço pela mercadoria, o caos visual e a enorme quantidade de informação que mal pode ser abarcada neste "espetáculo"), Atget atribui alta qualidade focal a todos os planos da imagem (como demanda o documento), não deixando quaisquer dúvidas a respeito de cada um dos elementos cênicos que compõem a narrativa que pretende tecer. No entanto, quanto mais a individualização dos ofícios na praça aumenta, maior é o efeito de desfoque utilizado pelo fotógrafo (que, também segundo as regras do documento, deveria ser assim retratado para oferecer maior legibilidade à cena). Através deste processo, sobre o qual Atget detinha completo controle técnico, a figura do petit métier aos poucos se "liberta" da cidade haussmannizada, à qual ele não mais pertence, um cenário que cada vez mais o recusa veementemente, obrigando-o a "destacar-se" mais e mais do espaço que insiste em ocupar. Ele move-se então, literalmente, a uma zona periférica, semelhante tanto à zona em que se encontrava na vida como também àquela em que se via o documento em relação às artes mais nobres - e também o fotógrafo documental em relação aos ofícios ligados à pintura ou fotografia dita artística. Atget introduz por esta via e desde a primeira imagem apresentada os elementos da modernidade que estruturam e determinam a forma por ele encontrada (ou, novamente, que the foi imposta!) para representar o trabalho nesta Paris: as novas construções arquitetônicas, componentes da empreitada em curso para modernizar e higienizar a cidade nos termos anteriormente descritos, as publicidades de lojas e mercadorias que avassaladoramente massacram a figura humana em tamanho e quantidade, a expansão e transmutação do capital e das novas formas de comércio e exploração da mão 
de obra, corporificados na referência feita ao anúncio da grande loja de departamentos Au Bon Marché, na notícia da existência e da expansão de outras lojas de natureza semelhante (o empreendedorismo de todos parece aqui revelado e posto em xeque!), na palavra "deuil", notícia da morte de um tipo de vida e de trabalho - o "luto" sugere esta morte, ou, por outra, o nascimento ou substituição de um tipo de capitalismo por outro, que se universaliza (lembremonos da palavra "universef") de modo ainda mais selvagem que o anterior.

"Connaissances" ganha aqui um valor mais extenso e profundo. Ao conformarse às regras impostas para a confecção do documento, o fotógrafo, ele também um petit métier, as violenta de tal modo a ponto de aniquilar "por dentro" seu restrito conceito, uma vez que, para produzi-lo, volta seu olhar para o mundo do trabalho, reproduzindo, com a máxima fidelidade, não a superficialidade de sua aparência imediata ou seu valor de face, mas a essência da experiência do Trabalho nas condições modernas, a saber, a homogeneização, a serialização, a permutabilidade, a transitoriedade, a abstração, o deslocamento forçado e a ferocidade cotidiana. Para tanto, exige que o observador não mais se sirva destas imagens como antes, mas, ao contrário, busque estabelecer relações e paralelos entre os fragmentos e o todo ao qual pertencem, atuando como um técnico ou "montador" que deverá reconstituir um conjunto de relações a partir dos elementos apresentados, reordenando-os para assim (e somente assim) atingir, após a montagem da obra (que não se esgota em si própria nem prescinde do papel ativo que deve desempenhar seu observador) a experiência do real, onde "real" significa a realidade cotidiana da experiência da classe trabalhadora e, por extensão, daquela de quem opera estes fragmentos, todos peças de uma mesma engrenagem. Encontramo-nos imersos no mundo da tatilidade benjaminiana ${ }^{35}$. As sensações de inadequação, impotência e torpor são as marcas constitutivas desta experiência nestas condições e estruturam e determinam a produção deste fotógrafo, um artista que se sabe antes de mais

\footnotetext{
35 Conforme a exposição feita no texto $A$ obra de arte na era de sua reprodutibilidade técnica. In
} BENJAMIN, W. Obras escolhidas - magia e técnica, arte e política. op. cit. 
nada um trabalhador ${ }^{36}$. É ele quem empreende a (verdadeira) reconstrução da velha Paris ao dissolver a nova como mera ilusão, expondo a discrepância entre o ambiente dado e o almejado, entre a liberdade real e a ilusória, ou seja, aquela representada pelas novas possibilidades de consumo.

Os elegantes clientes das grandes lojas de departamentos anunciadas no mercado de Atget (presentes por sua ausência) consumiam produtos refinados, num ambiente "distinto" daquele fotografado. As sensações de impotência e torpor eram, entretanto, semelhantes àquelas propiciadas pelas imagens do fotógrafo. Uma cleptômana da época justificou assim os crimes praticados numa dessa lojas:

\begin{abstract}
"Uma vez lançada na frenética atmosfera da loja de departamentos [...] senti-me cada vez mais tomada por uma perturbação, somente comparada à embriaguez, com a mesma tontura e intoxicação. Via tudo como por através de
\end{abstract}

36 Não existem documentos que atestem "abertamente" as opiniões políticas de Atget. No entanto, há evidências concretas das posições que o fotógrafo toma durante sua vida, por exemplo as doações que fez à Biblioteca Nacional de La Guerre Social, um jornal revolucionário de extrema esquerda e de L'avant garde, um jornal communard (as doações aconteceram após a invasão das respectivas redações pela polícia parisiense, que pretendia apreender e destruir exemplares das publicações; Atget entendeu que as doações poderiam salvaguardar o material). Em sua biblioteca particular guardava exemplares de livros como L'armée de Condé, um ataque dos dreyfusards contra o exército francês, seu caderno de recortes de jornais (uma espécie de "scrapbook") sobre o caso Dreyfus, desde seu início em 1894 até a morte de Zola em 1902, além de exemplares do jornal La bataille syndicale, da Central Geral dos Trabalhadores. As leituras que fazia apontavam assim suas posições anti-militaristas e pró-sindicalistas. O fotógrafo também fez diversas conferências nos cursos noturnos organizados por associações de trabalhadores parisienses, as chamadas "universités populaires". No álbum "Intérieurs Parisiens" Atget retrata, logo de início, o interior de seu apartamento, revelando, na exígua decoração, dois pôsteres: "La lanterne de Rochefort", sobre o qual sabe-se muito pouco, e "La Petite République Socialiste, 1899", outro jornal dreyfusard. Em várias de suas imagens, inclui-se como reflexo (num espelho, janela, porta de vidro ou similar), como em "Boutique Empire, 21, rue du Faubourg-Saint-Honoré, VIII, 1902" retratando a si mesmo como um petit métier e revelando, com riqueza de detalhes, as condições (inclusive materiais) de exercer seu ofício em Paris. Não parece restar dúvidas quanto ao fato de que Eugène Atget não apenas se identificava com os ideais da classe operária mas se percebia sobretudo como um trabalhador. Para referências às imagens citadas, ver NESBIT, M. e REYNAUD, F. Intérieurs Parisiens - Eugène Atget. Paris: Éditions Carré/Paris-Musées, 1992. HARRIS. D. Eugène Atget - Itinéraires parisiens. op. cit. 
uma névoa. Cada objeto incitava meu desejo e se tornava extraordinariamente atraente." 37

A significação política da obra de Atget consiste em sua profunda recusa da modernidade como ela se delineava. Ao representar as relações de trabalho modernas num espaço oco, incerto e sobretudo fantasmagórico, o ator frustrado remove a máscara que o burguês insistia em manter colada à face da modelo, que por demais maquiada para revelar seus traços e atendendo pelo nome de modernidade expunha-se nas vitrines dos grandes magazines. Desejar esta "mulher", ou melhor, "mulheres" no plural, artefatos serializados, objetos elegantes e comercializáveis, significava desejar o próprio valor de troca, ou, por outra, a própria essência do capitalismo; consumado o ato do desejo, a mercadoria celebra seu triunfo, a saber, a vitória do não-orgânico sobre o orgânico. Este cenário, tão evidente quanto paradoxal, tão fixo como inconstante, carecia de certa ordem. No papel de fotógrafo, Atget explicita os verdadeiros nuances, meio-tons e narrativas dessa ordem, ou seja, a peça burguesa: nomeia a construção que se apresentava naturalizada como um dado. O conhecido aparece como incerto e o reprimido ressurge, exibindo-se na sinistra e esgarçada tessitura da realidade material. $O$ efeito de choque produzido por tais imagens, retiradas de seus "contextos originais" e introduzidas no presente mais imediato, permite que as vejamos como imagens dialéticas, nas quais o démodé e o indesejável subitamente aparecem como moderno e o "novo" e "desejável" como eterna repetição do mesmo38.

"Com justiça, escreveu-se [que Atget] fotografou as ruas como quem fotografa o local de um crime. [...] [Este local] é fotografado por causa dos indícios que ele contém. Com Atget, as fotos se transformam em autos no processo da história. Nisso está sua significação política latente. Essas

${ }^{37}$ Cf. NESBIT, M. Atget's Seven Albums. op. cit. p. 158.

${ }^{38}$ Cf. BUCK-MORSS, S. Le flâneur, l'homme sandwich et la prostituée: politique de la flânerie. In WISMANN, H. (org.). Walter Benjamin et Paris. Paris: Éditions du Cerf, 2007. 
fotos orientam a recepção num sentido predeterminado. A contemplação livre não Ihes é adequada. Elas inquietam o observador, que pressente que deve seguir um caminho definido para se aproximar delas [...] a compreensão de cada imagem é condicionada pela sequência de todas as imagens anteriores." 39

A imagem que subsume a idéia do Trabalho moderno contida nos outros petits métiers até então apresentados, aprofundando ainda mais a reflexão sobre as relações entre modernização, modernidade e exploração do trabalho, é aquela do chiffonnier que conduz uma carroça com lixo (Figura 22), intitulada "XIII Quartier Croulebarde - un chiffonnier, le matin, avenue des Gobelins (1901)". Voltemo-nos a ela.

A fotografia nos mostra, com foco em todo o primeiro plano, um homem de corpo inteiro que puxa uma carroça repleta de sacos. Sua figura é diminuta se comparada à altura destes sacos atados por uma corda ao veículo, que ocupam grande porção da imagem. A parte inferior de seu corpo revela a perna direita à frente num evidente movimento de avanço, que forma, mesmo com o joelho levemente dobrado, uma linha reta, inclinada à esquerda em contiguidade com os sacos empilhados, criando grande movimento neste sentido. A perna esquerda, firmemente apoiada atrás, desestabiliza em alguma medida a oscilação anterior por constituir outra linha reta, inclinada à direita e menor em tamanho que a primeira, pois extingue-se no chapéu da pequena figura. De tais retas nasce uma tensão entre forças opostas e assimétricas.

A parte superior do homem mostra braços hirtos, ombros enrijecidos e olhar fixo no observador da imagem, contradizendo o que as pernas insinuam: num jogo formal que releva opostos e contradições, o chiffonnier, em movimento truncado, avança e recua, caminha e pára. O pouco que distinguimos num segundo plano

${ }^{39}$ Cf. BENJAMIN, W. A obra de arte na era de sua reprodutibilidade técnica. op. cit., pp.174-175. 
muito desfocado revela edifícios, carros e árvores num bulevar recentemente construído, área outrora reservada a artesãos e tecelões ${ }^{40}$. As diferenças entre este plano, com áreas de branco alvo (toda a parte esquerda), e a figura da carroça e do catador, que variam do cinza ao negro, fazem com que o homem em primeiro plano seja "catapultado" para fora da imagem, aproximando incondicionalmente o observador (que já se encontrava no interior das imagens) do objeto.

A fotografia concentra uma série de questões relevantes, a começar pela mobilidade urbana que agora se impunha àqueles que exerciam os pequenos ofícios, muitos à beira do desaparecimento. Os excluídos dos novos tipos de troca que aconteciam em Paris tornavam-se ambulantes, deveriam circular para, aspirando maior visibilidade (e aqui, qualquer semelhança com o processo de circulação do capital e das mercadorias não é mera coincidência!), maximizar seus ganhos (não era o que fazia nosso fotógrafo para garantir sua sobrevivência? E também nós, espectadores/trabalhadores ativos, no mercado de Atget?). A imagem também fala do crescimento da cidade:

"Na segunda metade do século XIX, quando o volume diário de lixo cresceu consideravelmente com o progresso da indústria e aumento do consumo, parte da atividade dos pequenos ofícios alterou suas características e começou a ligar-se à indústria do lixo urbano. A figura do chiffonnier apareceu como fração do lumpenproletariat - o último degrau da hierarquia social [...]. Ele logo se tornou parte do

40 O Boulevard des Gobelins, próximo à Place Saint Médard, também resulta dos Grandes Trabalhos de modernização de Paris sob o comando do prefeito Haussmann, com arquitetura típica do período. A tradicional fábrica de tapeçaria está instalada no número 42 . No número 73 encontra-se o Théâtre des Gobelins, construído em 1869 pelo empresário do meio artístico Henri Laroche, que detinha o controle de inúmeras outras salas de espetáculo do gênero na cidade. Não seria incorreto afirmar que a imagem, em certa medida e de maneira periférica, dê também notícia do avançado processo de mercantilização inclusive da produção artística em geral. 
imaginário social, representante de uma população inteira de pequenos comerciantes e sua mobilidade social."41

Eram estes os "profissionais" que levavam o lixo urbano para a periferia da cidade, nas comunidades em que viviam, onde, após algum tipo de reciclagem, retornava à metrópole na forma de novas mercadorias, outrora rejeitadas. Ao contrário da maior parte da produção fotográfica da época que dedicava algum lugar para a representação dos petits métiers, Atget não "humaniza" suas personagens. Os cartões postais contemporâneos à sua produção que circulavam com tais imagens insistiam, por exemplo, no aspecto "pitoresco" das figuras: o vendedor ambulante tornara-se, neles, um "poeta" das ruas, último baluarte da figura do trabalhador "bom" e sem "veleidades políticas" da velha Paris, idealizado por um burguês nostálgico que chorava seu desaparecimento. Estas imagens favoreciam a integração entre figura e ambiente ou paisagem. $O$ trabalhador jamais encontrava-se isolado - sempre por perto uma pequena multidão de compradores ou curiosos pronta a consumir seus produtos cuidadosamente expostos ou escutar suas canções. Implícita nas imagens a comunhão pacífica das diversas classes sociais nas ruas e avenidas de uma Paris bela e moderna, mas principalmente limpa, ou melhor, ascética e imperturbada; bem sucedida a eliminação de quaisquer conflitos. Atget repudia o pathos e a pacificação. Busca no chiffonnier, ocupação virtualmente inexistente no centro de Paris a partir de 1884 com a implementação de leis que deliberavam sobre o armazenamento e a coleta do lixo urbano ${ }^{42}$, a memória de formas de trabalho e sociabilidade anteriores àquelas que via se estratificar. Embora ameaçado pela dinâmica da industrialização, o catador não vendia sua força de trabalho para as modernas fábricas e ainda operava no arcaico sistema que the permitia relacionar local de trabalho à moradia, com alguma flexibilidade

${ }^{41}$ LE GALL, G. Atget - Life in Paris. Paris : Éditions Hazan, 1998, p. 17.

$42 \mathrm{O}$ prefeito de Paris Eugène-René Poubelle que concebeu tais leis emprestaria seu nome às modernas latas de lixo que, em francês, são conhecidas como "poubelles". 
de tarefas e execução do trabalho segundo suas necessidades ${ }^{43}$. Ousava ignorar horários fixos e, ao invés de atingir um determinado objetivo no âmbito da produção em larga escala, flanava pelas ruas de Paris: derivar (algum) prazer da vida (pública) e desrespeitar regras basilares da divisão social do trabalho não poderia encontrar-se mais à margem que qualquer outro habitante da cidade, ocupando uma zona ainda mais periférica, física, urbana e moral, adicionada e sobreposta àquela dos outros petits métiers; era a periferia da periferia.

Na maneira como foi representado nesta fotografia, o chiffonnier é parte de uma "escultura", uma natureza-morta apresentada como um componente indissociável do restante do conjunto do qual faz parte, a carroça e o lixo a ser reciclado. Isso graças sobretudo ao valor tonal (o grau de relativa homogeneidade dos cinzas) atribuído a todo o bloco do qual faz parte (porém, ao contrário da escultura como forma de expressão artística, Atget conta com o caráter perfectível inerente aos novos meios reprodutíveis para arquitetar seu teorema sobre a vida moderna). Assim, não há fronteiras precisas entre 0 homem, a carroça e os objetos descartados: todos têm "valor cênico" semelhante. Não há hierarquia entre os diferentes elementos que compõem a imagem, o que estabelece uma nova relação material radical. Ao reduzir o trabalhador (o corpo humano engajado em esforço, mero provedor de energia física) ao mínimo denominador comum de uma equação concebida nos termos da modernização de Paris já descritos, rebaixando-o e igualando-o ao lixo reciclável que voltará a ser consumido na capital, Atget revela formalmente, na circulação de ambos e nos termos artísticos, mecânicos e industriais, as contradições entre centro e periferia, "avanço" e "retrocesso", homem e mercadoria, agora indistintos um do outro. Tais contradições encontram-se plasmadas no corpo deste homem, completamente reificado. Aqui, o avanço, que não se dá sem resistência (expressa na tensão entre as linhas de força, no

43 A reconfiguração forçada do métier, que jamais deixou de existir completamente, foi posteriormente registrada por Atget num álbum intitulado "Zoniers. Vues et types de la zone militaire" da década de 1910. 
embate entre a figura e o fundo, no desencaixe entre a parte superior e inferior do corpo do retratado e no confronto "físico" entre a figura e o observadortrabalhador), é a marca do retrocesso: o primeiro convive com o segundo, é parte constituinte desse, e não pode senão ser o resultado final dessa operação de subtração social, na qual a cidade se dissolve e a sociedade se arruína. $O$ horror está ao alcance da mão; é isto que vemos em close.

"Aqui se anula aquela noção primária, construída habitualmente nos círculos normativos, de um pretenso movimento retilíneo para frente. Está claro que todo passo à frente importante é efetivamente acompanhado por um retorno ao começo ('às origens') ou, mais exatamente, por uma renovação do começo. Apenas a memória pode avançar, o esquecimento nunca. A memória regressa à origem e renova-a. Naturalmente, os próprios termos 'para frente' e 'para trás' perdem, nesta acepção, o seu caráter fechado, absoluto, ou antes, revelam por sua interação a natureza viva e paradoxal do movimento analisado e diversamente interpretado pelos filósofos (desde os eleatas até Bergson)." $" 4$

O mérito inexcedível do fotógrafo francês foi o de articular tais relações, banindo o insuportável "humanismo" que subjugava a fotografia (e que continuaria a fazê-lo na tradição fotográfica que o sucederia, por um Robert Doisneau ou um Willy Ronis), negando a pacificação e a neutralização do conflito e expurgando da imagem qualquer carga emocional que coibia a reflexão crítica. Ao romper com estratégias narrativas que pretendiam apagar a existência do ponto de vista (toda a produção fotográfica que se apresentava como mímese do real), explicitando-o na idéia da montagem e do choque que se revelam formalmente (alegorias de encontros de realidades na vida social), Atget liquida o conceito de

${ }^{44}$ Cf. BAKHTIN, M. Rabelais e Gógol (Arte do discurso e cultura cômica popular). In Questões de literatura e de estética - a teoria do romance. São Paulo: UNESP, 1993, p. 436. 
produção fotográfica como grau zero da escrita e indaga ao realismo ingênuo: "onde está a verdade estrutural?" As motivações que no fluxo tradicional da narrativa são internas à obra (o realismo como estruturação dramática do enredo, que pressupõe igualdade de forças, simetria de relações e ausência de conflito, ou seja, uma organização "democrática" dos materiais, formas e conteúdos, como aquele praticado pelo esteticismo pictorialista chique e esnobe) adquirem nas imagens do fotógrafo motivações de ordem histórica. Trata-se de instâncias épicas que buscam descrever e analisar processos, a partir de procedimentos como o distanciamento, o estranhamento, o salto, o lapso, a descontinuidade e a refuncionalização do objeto. Ao objetivar o sujeito, Atget faz de seu chiffonnier um objet trouvé: elevado à categoria de exemplo do típico, o trapeiro abandona sua função tradicional e Atget, ao chamar atenção para as técnicas que possibilitam a atribuição do novo papel, aponta para o Sujeito e sua História, revelando o caráter trágico contido no anódino. O fotógrafo catalisa a energia revolucionária contida no antiquado sem adotar um ponto de vista que privilegie, por um lado, o idealismo ou a nostalgia pré-capitalista ou, por outro, aquele do progresso como marca de desenvolvimento. Em Atget, o sentido histórico da vitória do capital é o índice de sua decadência. Ele expõe assim a verdade estrutural de seu tempo, explicitando o ponto de vista do oprimido, sua posição nos termos de sua classe, a assimetria das relações sociais às quais se encontra subordinado (o embate entre este sujeito não-transcendental e seus materiais) e a estrutura anti-democrática que organiza e pauta sua existência. Alinha arte e crítica, uma arte dialógica e negativa: as imagens almejam desautomatizar a percepção embotada do sujeito-observador falando do que "é" por aquilo que "não são". Nestes termos, além de desmascarar o engano onde ele era mais bem fundado nas aparências ${ }^{45}$, Atget antecipa, utopicamente, um regime no qual as restrições das jornadas de trabalho e a automatização da produção não serão frutos de insatisfação ou crises, mas resultado humano desejável. O potencial produtivo da tecnologia e as possibilidades de efetivação

\footnotetext{
${ }^{45}$ A formulação é de Roberto Schwarz. In SCHWARZ, Roberto. Nacional por subtração. In Que horas são? São Paulo: Companhia das Letras, 1989.
} 
da felicidade universal encontram-se, assim, pela veemente negação, tão ausentes como presentes.

Mas a negação não é um fim em si. Atget não pretende ao longo de sua obra apenas "indicar" certos fenômenos, mas desvendar, nas diversas zonas pela qual circula, artística, profissional, social, urbana e material, aspectos particulares de um modus operandi. Na negação da negação, o que era "zona apartada" na vida torna-se, em Atget, "zona de contato", "onde o contraditório e o incompatível se congregam para renascerem como ligação"46. Esta é a essência que revela a técnica e a originalidade de Atget. Todas as formas abstratas ou fixas, com pretensão ao absoluto e sem base na experiência cotidiana e popular (todas as formas artísticas de "cavalete") são rechaçadas porque não cumprem uma função verdadeiramente organizadora - agora, nos termos da ciência e da política. Morre assim a fotografia como arte (a contemplação estética, "a construção mais ou menos artística de uma fotografia, que transforma a vivência em objeto a ser apropriado pela câmera"47) para nascer a arte como fotografia (a transformação da técnica na arte que marcha conscientemente rumo à perfectibilidade):

"A cópia da realidade não é mais parte dos esforços realistas. [...] O artista constitui nas formas de sua arte sua própria realidade e concebe o realismo como consciência do objeto autêntico, autônomo quanto à sua forma e seu conteúdo. Este objeto não é uma reprodução das coisas do mundo exterior mas é, do início ao fim, concebido fora das linhas de projeção que poderiam relacioná-lo à realidade imediata. Se considerarmos, do ponto de vista deste realismo autêntico, os objetos dos criadores ou artistas não-objetivos contemporâneos [mestres cubistas, suprematistas ou

${ }^{46}$ Cf. BAKHTIN, M. op. cit. p. 436.

${ }^{47}$ BENJAMIN, W. Obras escolhidas - magia e técnica, arte e política. op. cit. p. 104. 
construtivistas que romperam com a representação fiel ao objeto], nos daremos conta de que se encontram, tanto em sua forma como em sua matéria, distanciados dos objetos utilitários que deveriam ser as obras de arte antigas. Neles, os materiais [...] e a forma (a superfície plana em duas dimensões) recriam inevitavelmente a convenção, a artificialidade, ou seja, não a autenticidade, mas unicamente o caráter de projeção das formas da obra de arte [le caractère projectionnel des formes de l'œuvre d'art]."48

O fotógrafo entende que somente este conceito de realismo (um realismo moral), o "estar na realidade [e o] intervir em seus processos"49, possibilitará estabelecer relações formais entre "o público e o privado, o fora e o dentro, o passado e o presente (a História como concebida por Walter Benjamin), a embrutecedora monotonia (o reino da mercadoria) e a desordem dionisíaca final (Paris como um salão de diversões, Paris como Comuna, Paris como um diorama em chamas)"50. É nesta, ou contra esta Paris que Eugène Atget atualiza as demandas baudelairianas para a arte moderna e, em coro com o poeta, sussurra: "o lado belo da vida!".

\footnotetext{
${ }^{48}$ Cf. TARABOUKINE, N. Le dernier tableau - du chevalet à la machine - pour une théorie de la peinture. Écrits sur l'art et l'histoire de l'art à l'époque du constructivisme russe, présentés par Andrei Nakov. op. cit. pp. 36-37.

${ }^{49}$ Cf. ARGAN, G. C. A escultura de Picasso. In A arte moderna na Europa - de Hogarth a Picasso. op. cit. p. 559.

${ }^{50}$ Explicito as aproximações entre a obra de Eugène Atget e os escritos de Walter Benjamin nas Passagens, no qual o filósofo, assim como o fotógrafo, opera como um chiffonnier que coleta os cacos da História. Cf. CLARK, T. J. Será que Benjamin devia ter lido Marx? In CLARK, T. J. Modernismos (org. Sonia Salzstein). São Paulo: Cosac Naify, 2007, p. 290.
} 
Em L'Assomoir, Zola já havia dado notícia da relação entre ambiente material e os objetos que o povoam ${ }^{51}$, ao retratar um momento anterior do mesmo processo de exclusão que o fotógrafo retoma no final do século XIX e início do XX. Atget, de par com Zola, atualiza o projeto realista: de modo semelhante, ambos parecem, como demonstrou Antonio Candido em notável observação, propor uma maneira de representação do objeto na qual

"[a] ação se torna quase descrição, na medida em que os atos são manipulações; a narrativa parece uma concatenação de coisas e o enredo se dissolve no ambiente, que vem a primeiro plano através das constelações de objetos e dos atos executados em função deles. Aqui, poderíamos dizer contrariando o famoso ensaio de Lukács que descrever é narrar." 52

Em outras palavras, a narração tradicional na obra de arte tradicional (onde "tradicional" significa "em conformidade com os padrões e regras burgueses de representação") transforma-se na descrição que pretende "emperrar" o andamento da ação burguesa. Atget, na esteira do mestre naturalista, descreve e, ao fazê-lo, enxuga e intensifica o signo até condensar a comunicação numa solicitação visual que, para além da mera narração, é um juízo que se tece sobre o fato. O chiffonnier de Atget retoma, atualiza e aprofunda a crítica à modernidade estabelecendo diálogo com a produção artística que o precede, a obra escultórica de Daumier, mais especificamente seu Ratapoil, uma massa de cicatrizes, ativo, altivo e destituído ${ }^{53}$. O fotógrafo confere a seu chiffonnier um

${ }^{51}$ Cf. ZOLA, É. L'Assommoir. Paris: PML, 1995.

52 Cf. CANDIDO, A. Degradação do espaço. In 0 discurso e a cidade. São Paulo: Livraria Duas Cidades, 1993, p. 72.

53 Embora não caiba aqui desenvolver todos os paralelos entre as obras de Daumier e de Atget, gostaria de salientar que ambos antecipam e/ou fazem uso em suas imagens de procedimentos típicos e caros à arte cinematográfica: a mobilidade e o percurso da câmera em direção ao objeto (o raccord cinematográfico, ou seja, "o elemento de continuidade entre dois ou mais planos") e a montagem. Na série que executou sobre músicos ambulantes, o pintor "abole as fronteiras que existem entre os diferentes tipos de espetáculo. Experimenta diversos ângulos de 
grau de densidade material suficiente para apresentá-lo como coisa. A energia com a qual Daumier representava o Mal e sua sequela, descritos nos famosos versos de Baudelaire ${ }^{54}$, encontra-se também em Atget, que enfrenta esta "massa sólida" como um trabalhador que se engalfinha com a matéria bruta (Van Gogh).

A produção de imagens que "descreve" seu objeto de estudo nesses termos exige um tipo muito específico de contemplação. Tem caráter modelar e ensina o observador (e outros produtores) a ver (e produzir para revelar) o que a ideologia encobre. Noutras palavras, promove uma (re)educação política do olhar. Daí a necessidade de recobrar a chave alegórica dos símbolos e procedimentos utilizados, bem como suas imbricações com o momento sóciohistórico com o qual se relaciona e com quem estabelece diálogo para sua compreensão. Como vimos, o chiffonier não era apenas uma personagem, mas o representante de todo um grupo de trabalhadores excluídos no processo de modernização de Paris.

\begin{abstract}
"A Boemia [o mundo da mais absoluta miséria e recusa da sociedade burguesa] na Paris da segunda metade do século XIX era verdadeiramente uma classe social, um local de real dissensão. Se quiséssemos localizá-la na complexa estrutura social da cidade, deveríamos buscá-la não nos estudantes do Quartier Latin mas nas classes dangereuses. Era esse elemento perigoso - essa turba de desempregados, criminosos e déclassés de toda sorte, as primeiras vítimas, os primeiros escombros do processo de industrialização - que compunha uma parte do exército que luta as batalhas de
\end{abstract}

visão, fazendo-os circular em torno do objeto como uma câmera que busca o melhor ponto de vista para atribuir maior intensidade à ação. É moderno tanto no enquadramento quanto na iluminação e anuncia a arte cinematográfica." A descrição acima poderia certamente aplicar-se, guardadas as devidas particularidades, à produção visual do fotógrafo. Para referências à obra de Daumier, ver LÉVẾQUE, J.-J. Honoré Daumier. Paris: ACR Édition, 1999, p. 154. Para considerações sobre os procedimentos cinematográficos citados, ver $\mathrm{BURCH}, \mathrm{N}$. Práxis do cinema. São Paulo: Perspectiva, 2006.

54 "Vers pour le portrait d'Honoré Daumier". In Baudelaire - CEuvres Complètes. op. cit. 
junho de 1848. O grande historiador social do período, Remi Gossez, encerra sua descrição sobre as origens dos insurgentes mencionando que a última categoria social dos rebeldes era composta por 'excluídos sociais de todo tipo: vagabundos, trabalhadores informais, chiffoniers, uma massa conhecida como la Bohème." 55

Os métodos utilizados para retratar o chiffonnier, evidentes na atribuição de foco e nas relação entre figura e fundo, revelam, no limite, o espaço abstrato da Paris haussmanizada, lugar da abstração do dinheiro, agora capital financeirizado. De par com o chiffonnier de Baudelaire e com aquele de Manet (inclusive na sua versão para "O velho músico"), o chiffonnier de Atget é um passo adiante na figuração da abstração dos processos financeiros, decorrência da trágica concretude que acompanha a modernidade. Atget compreende a lição do poeta e do pintor: Paris produz seu spleen e o spleen produz a sua Paris. Se há melancolia, ela é revolucionária, e exige que a produção artística reflita o transitório, extraindo dele a fração que se apresenta como eterno - são estas as evidências nos autos de um processo histórico das quais falara Benjamin ao comentar as imagens do fotógrafo.

No diálogo com a pintura que pretendia dar notícia de processos semelhantes, Atget explicita a crise da representação entre figura e fundo encerrada em parte da produção da Escola de Barbizon (Millet), ele próprio um membro tributário da tradição realista ${ }^{56}$, dando um passo além - agora no âmbito da produção

${ }_{55}$ Cf. CLARK, T. J. Image of the People - Gustave Courbet and the 1848 Revolution. op. cit. p. 33.

56 Pretendi, no curso desta exposição, propor uma avaliação da obra de Eugène Atget como tributária do programa enunciado pelo Realismo francês, não apenas em termos estéticos mas políticos. Neste movimento, como na obra de Atget, "um conceito novo e ampliado de História, acompanhado de uma radical alteração da percepção temporal, foi central para a abordagem 
artística em sua fase de reprodutibilidade técnica - na problematização das questões enunciadas nos termos da pintura a óleo: subverte brutalmente a idéia de mímese do real fotográfico (atualiza o realismo de Courbet e, na fotografia, põe em xeque aquele de Charles Marville ${ }^{57}$ ), aniquila a composição perspéctica, estrutural ao meio fotográfico (a janela perspéctica de Dürer é definitivamente fechada; a geometria que esquadrinhava a vida volta-se, em Atget, contra si mesma: o que era estrutura transforma-se em atmosfera, onde tudo é soma de desencontros; o materialismo se impõe face ao idealismo e Atget avança em relação às conquistas da pintura), introduz um "eu" na imagem, explicitando-a enquanto construção (Manet), re-avalia a unidade do impressionismo (Monet) e da produção fotográfica pictorialista, consectário desta escola e, finalmente, recusa de modo frontal o modelo tradicional contemplativo. Ao utilizar-se da fotografia documental, uma forma menos "artística", e portanto distanciada de suas "primas ricas", a fotografia pictorialista e a pintura de cavalete corolário da

realista. Pessoas comuns - pequenos comerciantes, trabalhadores e camponeses - em suas funções cotidianas começaram a aparecer num palco outrora reservado exclusivamente aos reis, nobres, diplomatas e heróis." Ao compararmos por exemplo A cantora de rua (1862), de E. Manet com as fotografias dos pequenos ofícios feitas por Atget, a "genealogia" do fotógrafo francês, tributária sobretudo do segundo período do Realismo, se evidencia: "[nesta pintura de Manet] todo um segmento distinto do milieu urbano é capturado numa só figura, retratada, como que pelas lentes de uma câmera fotográfica, entre as idas e vindas de uma porta de bar; a mão levada à boca, os arredores aos quais outrora pertencera mal-esboçados, entrevistos de relance pela fugidia abertura [da porta retratada no canto esquerdo da tela]". Como Atget, aqui Manet trata seu petit métier como natureza-morta: "uma jovem, bastante conhecida nas redondezas do Panthéon, sai de uma brasserie comendo cerejas que leva envoltas numa folha de papel. A obra como todo é de um cinza doce e amarelado e a natureza me parece aí analisada com simpatia e exatidão extremas. Tal pintura tem, fora o assunto, uma austeridade que a enobrece; nela percebemos a busca pela verdade, o labor consciente de um homem que pretende, antes de mais nada, dizer francamente o que vemos diante de nós". Cf. NOCHLIN, L. Realism. Londres: Penguin Books, 1990, p. 23 e p. 160 e ZOLA, É. Une nouvelle manière en peinture (1867). In ZOLA, E. Le bon combat - de Courbet aux Impressionistes. Paris: Hermann, 1974, p. 86. A obra de Atget também não é estranha às reivindicações "proto-realistas" de Diderot e sua prédisposição para as artes fotográficas: a partir da inteligência desnormatizada, o olhar palaciano (burguês) sai de cena para dar lugar àquele plebeu que, fruto de operação crítica, pretende apreender a sociedade pela reconstrução materialista, pelo poder sintético e pela subordinação à idéia central na elaboração da imagem. Cf. DIDEROT, D. Salons. op. cit.

57 O fotógrafo adere ao programa de reformas instaurado por Napoleão III formal e ideologicamente, produzindo imagens que privilegiam o ecletismo artístico e o aspecto "pitoresco" da "nova" Paris (em conformidade com a fração mais reacionária da École de Barbizon) repondo, nos termos da fotografia, as exigências feitas pelas academias de belas artes e pelos salões. Suas escolhas estéticas revelam, sobretudo, o pacto de classe que fizera com os clientes para os quais trabalhava. Para uma interpretação radicalmente distinta desta e referência às imagens, ver THÉZY, M. Marville Paris. Paris: Hazan, 1994. 
arte oficial da Monarquia de Julho, a pintura eclética do juste milieu, ele fala, nos mesmos termos rebaixados do documento, da propaganda e do cartaz, sobre a degradação da vida social daqueles que atuavam nos capítulos seguintes do processo de modernização iniciado por Napoleão I e levado adiante por seus sucessores. Nestes termos, eleva o estudo (neste caso, o documento) à categoria de morceau fait.

Seu equipamento fotográfico e sua maneira de fotografar, completamente alheios aos processos mais modernos de então, que incluíam lentes especiais, filtros e correção de "imperfeições" da imagem na "pós-produção", ratificam a zona pela qual circulava. Porém, conforme já dito, ao mesmo tempo que dava notícia da obsolescência daquelas personagens numa peça que alterava seu enredo, proporcionando-Ihes papéis sociais cada vez mais indesejados, traziaos para a "boca da cena". Eram eles as personagens principais e deles as silenciosas linhas, as "falas" mais importantes num cenário que, se por um lado se dissolvia, em sua dissolução expunha o processo, guardando parte da memória do que havia outrora sido. Era esta memória, tingida de sentido, que deveria ser recobrada:

"[...] o comerciante posando para a câmera era como um ator apontando para si próprio no palco do teatro urbano. $\mathrm{Na}$ linguagem do teatro francês, o pointe era o momento áureo da peça, quando o ator, na boca da cena, aproximava-se da platéia para falar seu monólogo olhando para o público. Esta convenção tinha a particularidade de interromper a ação que se dava no palco, da mesma forma que o pequeno comerciante cessa sua atividade no momento em que conscientemente se engaja num processo de representação." 58

${ }^{58}$ Cf. LE GALL. op. cit. pp. $15-17$. 
De objeto "fotografável", o petit métier evolui à categoria de sujeito fotográfico. Se a cidade se tornara o grande teatro do orgulho burguês, Atget opõe a (aparente) simplicidade de suas fotografias, privilegiando a pura frontalidade e a legibilidade, às formas espetaculares da modernização da cidade. Ao dar notícia da espetacularização da vida social59, "interrompe a ação" dramática da peça burguesa, para envolver o espectador de suas imagens num outro tipo de palco, mais "científico", com intuito "didático". O fotógrafo expõe uma contradição sistêmica, lembrando-nos: 1. que as lutas de classes se iniciam na extração da mais-valia, não no confronto revolucionário armado, 2. que a opressão não é um dado, mas um processo de reposição contínuo e truculento a serviço dos interesses do capital, 3. que agora somente a classe proletária poderá tornar-se sujeito revolucionário mas que, para tanto, 4. deve despertar sua consciência ou memória adormecida, avivá-la de sua letargia. Em sua representação não há lugar para o ilusionismo. Nestes termos, o "teatro" de Atget guarda, além de semelhança com o projeto naturalista de Zola, seu interlocutor direto, afinidades

\footnotetext{
59 Novamente aqui revelam-se paralelos de interesse entre a produção fotográfica de Eugène Atget e aquela dos Realistas, corroborando a tese de que o trabalho artístico-fotográfico de Atget retoma, atualiza e radicaliza o projeto desses artistas. Não pretendo neste momento discorrer sobre todas as implicações do conceito de "espetáculo" e "espetacularização", desenvolvidas, como se sabe, no trabalho teórico do grupo intitulado Internacional Situacionista, na figura de um de seus maiores expoentes, Guy Debord. Para tanto, ver DEBORD, Guy. La société du spectacle. op. cit. Tomando como base em termos gerais o conceito de "espetáculo" como uma tentativa de reavaliar o sistema capitalista de um ponto de vista essencialmente marxista, reforço os paralelos entre a produção realista e aquela do fotógrafo francês nos termos da retomada de um projeto que se pretende reação a outro, a saber, a modernização como projeto inacabado. "Não resta dúvida que Manet e seus companheiros olharam para a tradição que os precedia, para Velásquez e Hals, por exemplo. Mas o que mais parecia impressioná-los era a evidência de uma inconsistência, manifesta e papável, e não o fato da imagem estar no final preservada, de alguma maneira, da extinção. Esta mudança de percepção leva, por um lado, a enfatizarem os meios materiais pelos quais a ilusão e a semelhança são construídos [...], e por outro, a um novo conjunto de propostas que a representação formal deveria assumir, até onde era possível fazê-lo sem má-fé. 'O escopo e o objetivo de Manet e seus seguidores', segundo Mallarmé em artigo de 1876 [...] 'é que a pintura deve novamente aprofundar-se em suas causas...' [...] A ênfase na exatidão, simplicidade e atenção imperturbável é algo que ocorreria repetidamente nos próximos cem anos e não pode ser atribuída à arte que Manet fez nascer. A imperturbável atenção rapidamente cedeu lugar à incerteza (nisto, o caso de Cézanne é exemplar). As dúvidas sobre o ato de ver tornaram-se dúvidas sobre quase tudo que envolvia o ato de pintar. Logo, a incerteza tornou-se um valor em si. Poderíamos quase dizer que se tornara uma estética." Atget retoma e atualiza precisamente essa estética. Cf. CLARK, T. J. The Painting of Modern Life. In FRASCINA, F. e HARRIS, J. Art in Modern Cuture - an Anthology of Critical Texts. Nova York: Phaidon Press Limited \& Open University, 2006, pp. $44-45$.
} 
com a posterior produção de Brecht: não propõe apresentá-lo como "cópia do real", mas síntese de uma determinada realidade; este é seu "realismo épico"60.

Por esse motivo, reduzir sua obra à mera "documentação" da "Velha Paris" seria ignorar o múltiplo caráter de suas imagens, residindo aí uma de suas maiores contribuições: o saneamento da atmosfera sufocante da fotografia tradicional - 0 retrato lisonjeiro burguês.

"Atget foi um ator que retirou a máscara, descontente com sua profissão, e tentou, igualmente, desmascarar a realidade. Viveu em Paris, pobre e desconhecido, desfazia-se de suas fotografias doando-as a amadores tão excêntricos como ele, [...] deixando uma obra de mais de quatro mil imagens. Berenice Abbott, de Nova lorque, recolheu essas fotos, das quais Camille Recht publicou uma seleção, num volume de extraordinária beleza. Os publicistas contemporâneos nada sabiam sobre aquele homem que passava a maior parte do tempo percorrendo os ateliês, com suas fotos, vendendo-as por alguns cêntimos, muitas vezes ao mesmo preço que aqueles cartões postais que em torno de 1900 representavam belas paisagens urbanas envoltas numa noite azulada, com uma lua retocada. Ele atingiu o pólo da suprema maestria, mas na amarga modéstia de um grande artista, que sempre viveu na sombra, deixou de plantar ali o seu pavilhão. Por isso, muitos julgam ter descoberto aquele pólo que Atget já alcançara antes deles. Com efeito, as fotos parisienses de Atget são as precursoras da fotografia surrealista, a

60 Cf. MICHEL, R. E SAHUT, M-C. David - L'Art et le Politique. op. cit. A partir da formulação do termo "realismo épico" por Régis Michel para descrever parte da produção de David em seu momento revolucionário (Marat Assassinado, 1793), gostaria de pensar a obra de Atget, ao aproximá-la do período, como corolário de um projeto inacabado, iniciado pelos setores mais progressistas na Revolução Francesa e que, à época do fotógrafo, dá notícia não apenas da interrupção do projeto mas de suas consequências mais nefastas. 
vanguarda do único destacamento verdadeiramente expressivo que o surrealismo conseguiu pôr em marcha. Foi o primeiro a desinfetar a atmosfera sufocante difundida pela fotografia convencional, especializada em retratos, durante a época da decadência. Ele saneia essa atmosfera, purifica-a $[\ldots]^{\prime 61}$

O "teatro" de Atget nos informa sobre as possibilidades e restrições do fazer artístico-fotográfico, sobre os embates entre o repertório das forças produtivas nas reais relações de produção. Como um chiffonier de imagens, que coleciona "os dejetos da história [como] um autor incógnito que não reivindica privilégios perdidos"62, ele detém enorme controle técnico e vasto repertório artístico para execução de suas fotografias. Porém, à margem do mercado fotográfico que se desenvolvia em direção à representação lisonjeira da burguesia (e da classe média ascendente) nas glaciais cartes-de-visite, ou do crescente mercado da fotografia de paisagem, de lugares exóticos - a produção fotográfica aliara-se à expansão imperialista ${ }^{63}$-, Atget se tornava um trabalhador tão obsoleto quanto suas "personagens". Um flâneur em Paris com uma velha câmera, fora do dernier cri da indústria e do mercado fotográficos, não poderia senão reunir evidências dos processos acima descritos, cifradas em imagens que não admitiam o idílio que o romance popular, os tableaux vivants e a pintura mais reacionária da época insistiam em manter artificialmente vivo. Terminou sua vida na miséria. Afortunadamente, não viu sua obra elevada ao panteão da alta cultura, primeiro em Nova York pelas mãos bem-intencionadas de Berenice Abbott, fotógrafa e assistente de Man Ray em Paris, depois por uma das frações mais reacionárias da fotografia alemã, os fotógrafos da Nova Objetividade, e

${ }^{61}$ BENJAMIN, W. Pequena história da fotografia. In Obras escolhidas - magia e técnica, arte e política. São Paulo: Brasiliense, 1993, pp.100 - 101. Para referências às imagens e ao texto de Recht citados por Benjamin, ver RECHT, C. Eugène Atget Lichtbilder. Munique: Rogner \& Bernhard GmbH \& Co. Verlags KB, 1975.

62 WOHLFARTH, I. Et cetera? De l' historien comme chiffonnier. In WISMANN, H. (org.). Walter Benjamin et Paris. op. cit. p. 562.

${ }^{63}$ A esse respeito ver FABRIS, A. A invenção da fotografia: repercussões sociais. In FABRIS, A. (org.) Fotografia - usos e funções no século XIX. São Paulo: EDUSP, 1998. 
mais recentemente, com exposições encomiásticas nos mais importantes museus e galerias da Europa e Estados Unidos. Os que o fizeram não foram capazes de perceber que a perspectiva da qual falava, como falaram também Baudelaire, Daumier, Manet e tantos outros, revelava a imagem devastadora do processo de modernização inacabado visto de dentro por uma de suas vítimas, "aprisionada no cativeiro das forças produtivas" 64 .

O ator que um dia pretendera brilhar na Comédie Française evoluiu finalmente para um certo primitivismo. Ausentes a metafísica, as hipóteses transcendentes, o populismo, o subterfúgio, o disfarce, enfim, o reino da ilusão generalizada, resta em Atget o dado imediato dos sentidos no ambiente de tirania e opressão que os tornavam possíveis, a realidade externa aspirada para o interior da obra (como numa "perspectiva realis", "para fora" da imagem), a destruição do espaço concebido aprioristicamente, um anti-espaço, capturado fragmentariamente e representado como matéria determinada pela consciência. $\mathrm{Na}$ recusa do historicismo temporal, a vida não como "é" ou "deveria ser lembrada", mas como fora esquecida, e na explicitação da noção moderna de trabalho assenta 0 alicerce de uma produção fotográfica coletivamente edificada, fabricada com o auxílio de artesãos anônimos num canteiro de obras. Flâneur, chiffonnier, colecionador ou prostituta, Atget refuncionaliza o papel de delator que exercera outrora no teatro: o décor de seu documento é a vida cotidiana, onde as marcas da classe encontram-se todas prêt-à-porter:

"Reconhecemos concretamente no flâneur nosso próprio modo consumista de ser. A grande loja de departamentos é sua última parada. A flânerie como forma de percepção é preservada pela possibilidade da substituição característica das pessoas e coisas na sociedade de massa e pela gratificação puramente imaginária que nos oferece a

${ }^{64} \mathrm{Cf}$. COSTA, I. C. Brecht no cativeiro das forças produtivas. In CEVASCO, M. E. e OHATA, M. (org.). Um crítico na periferia do capitalismo: reflexões sobre a obra de Roberto Schwarz. op. cit. 
publicidade, os jornais ilustrados, as revistas de moda e pornográficas, que se baseiam no princípio da flânerie: olhe apenas com os olhos." 65

A Arte degrada-se finalmente em técnica e é agora homólogo do Trabalho. Aboliu-se a distinção entre fruição e produção, ou seja, a reflexão sobre os modos de produção é agora ela própria uma produção. Como fotógrafo, Atget refez o elo entre o ouvrier-artisan e o maître-créateur, ou, por outra, entre o trabalho manual e o trabalho intelectual (Erfahrung). Integrante do coletivo de artistas que inspirou as demandas da Revolução de 1917 (que reformuladas por Brecht ganharam dimensão filosófica em Walter Benjamin) não abasteceu o aparelho de produção "sem o modificar, na medida do possível, num sentido socialista"66. Ensinou a fazer dançar as velhas e petrificadas formas artísticas, tocando para elas sua própria música.

${ }^{65}$ Cf. BUCK-MORSS, S. Le flâneur, l'homme sandwich et la prostituée: politique de la flânerie. In WISMANN, Heins (org.). op. cit. p. 367.

${ }^{66}$ Cf. BENJAMIN, W. Obras escolhidas - magia e técnica, arte e política. op. cit. p. 127. 


\title{
CAPÍTULO 4:
}

\section{Encenação do trabalho e trabalho de encenação: o caso Weegee}

\author{
"Paris muda! Mas nada em minha nostalgia \\ Mudou! novos palácios, andaimes, lajedos, \\ Velhos subúrbios, tudo em mim é alegoria, \\ E essas lembranças pesam mais que rochedos." ${ }^{1}$
}

"Embora a Frente Popular tenha sido derrotada pelas forças do século norteamericano e os anos trinta pareciam ter chegado ao fim por volta de 1948, as obras da Frente Cultural tiveram um profundo impacto na cultura norteamericana, dando conteúdo a toda a obra de duas gerações de artistas e intelectuais. Pela primeira vez na história dos Estados Unidos uma cultura da classe trabalhadora deixava marcas significativas nas instituições hegemônicas. Tanto a alta cultura como a cultura de massa adquiriram um notável sotaque plebeu."2

"[...] por realismo não podemos razoavelmente entender a representação da realidade objetiva, como é dada na experiência empírica comum. [...] [O] realismo não pode em nenhum caso postular ou pressupor uma concepção organizada da realidade, mas apenas indicar uma determinada atitude da consciência perante a problemática do real; mais precisamente, uma atitude de engajamento e participação, em vez de evasão ou distanciamento. Mais precisamente ainda: é realista toda posição de luta ou de intervenção ativa na realidade de uma situação histórica; e é realista a recusa de toda metafísica, tanto do conteúdo quanto da forma - aliás, a recusa de toda possível distinção ou categorização de conteúdo e forma."3

Weegee carece de sofisticação técnica; a banalidade de temas envoltos por uma névoa de vulgaridade generalizada e desnecessária resulta em uma retórica ao

\footnotetext{
1 "Paris change! mais rien dans ma mélancolie / N'a bougé! palais neufs, échafaudages, blocs, / Vieux faubourgs, tout pour moi devient allégorie, / Et mes chers souvenirs sont plus lourds que des rocs." Cf. O Cisne. In BAUDELARE, C. Poesia e prosa. op. cit. p. 173.

2 In DENNING, M. The Cultural Front - The Laboring of American Culture in the Twentieth Century. Londres e Nova York: Verso, 1997, p. xx.

${ }^{3}$ In ARGAN, G. C. Picasso: o símbolo e o mito. In A arte moderna na Europa - de Hogarth a Picasso. op cit. p. 560.
} 
mesmo tempo ordinária e excessiva, imperdoavelmente agressiva e kitsch, que não faz senão expor publicamente um segredo já por todos conhecido. Trata-se de mais um cínico oportunista; sua produção não pode, portanto, ser confundida com a verdadeira arte de vanguarda norte-americana. Weegee se utiliza de uma linguagem demasiadamente popular, é certo, mas seu mérito consiste sobretudo em documentar, em suas melhores imagens, aspectos do cotidiano da grande metrópole, revelando as privações e o isolamento que atormentam as almas de seus habitantes. Weegee é um gênio oriundo do sub-mundo, um talento sem par que, a despeito de todas as adversidades materiais que o acometeram, conseguiu ascender ao panteão dos maiores fotógrafos americanos ao estabelecer, graças à sensibilidade inerente aos maiores Artistas, elos estéticos dos mais sofisticados entre a arte popular e a arte culta. Weegee faz arte engajada e suas fotografias almejam uma apreciação incisiva da máquina capitalista. Quando o assunto é Weegee, o dissenso parece ser o único consenso entre a crítica especializada ${ }^{4}$.

Ao divergir categoricamente sobre sua obra, ou simplesmente a ignorar, o que não é incomum em compêndios ou cursos de fotografia, a crítica tende a fazê-lo quase sempre de modo passional e intenso, um reflexo e um sub-produto de algo por demais marcante nas imagens por ele produzidas. E o que, afinal,

\footnotetext{
${ }^{4}$ Alguns exemplos de posições conflituosas na fortuna crítica: Colin Westerbeck menciona a "vulgaridade grosseira" de Weegee (the gruff vulgarity of Weegee) ao considerar a produção fotográfica de um de seus discípulos, (o mais sofisticado?) Garry Winogrand. Cf. FRIZOT, M. A New History of Photography. Colônia: Könemann Verlagsgesellschaft mnH, 1998, p. 654. "Insolente" (insolent) é o adjetivo utilizado por Colin Osman para descrever Weegee por oposição a Lisette Model, uma fotógrafa "fina" e "distinta" (fine et distinguée). Cf. La photographie sûre d'elle-même (1930 - 1950). In LEMAGNY, J.-C. e ROUILLÉ, A. (ed.). Histoire de la Photographie. Paris: Larousse, 1998, p. 172. "Atrevido e descarado mas observador" (brash but observant) é a definição que encontra Naomi Rosenblum para o fotógrafo. Cf. ROSENBLUM, N. op. cit. p. 485 (meus grifos). Naked City é definido como "um grotesco tragi-cômico" pelo já mencionado Dictionnaire Mondial de la Photographie (p. 661). Finalmente, Miles Orvell entende que Weegee é um "Artista" do tipo "primitivo urbano" que utiliza sua câmera para revelar a "desordem resultante do mundo natural", sustentando que "a estranha [peculiar] contribuição de Weegee para o campo da fotografia urbana foi sua (até então inédita) definição da cidade moderna: uma coleção de voyeurs libertos de envolvimento com o assunto retratado, testemunhas que se chocam ou se divertem com a desordem do espetáculo da vida contemporânea." Cf. ORVELL, M. Weegee's Voyeurism and the Mastery of Urban Disorder. In After the Machine - Visual Arts and the Erasing of Cultural Boundaries. Jackson: University Press of Mississippi, 1995, p. 96.
} 
existiria nestas fotografias em grau suficientemente elevado para provocar tal reação? O que revelariam, para além das aparências, edifícios em chamas, amantes furtivos em praias desertas, habitantes de cortiços nova-iorquinos exauridos em escadas de incêndio, fãs histéricas por seus ídolos, assassinatos variados, crianças reunidas ao redor de cadáveres, vagabundos e pedintes, personalidades e socialites ou animais de circo em posições inusitadas? E mais: o que significam todas estas imagens agrupadas sob forma de livro organizado pelo fotógrafo e publicado em Nova York em meados dos anos quarenta? Refiro-me a Naked City (1945), primeiro livro do fotógrafo e sucesso instantâneo no mercado editorial americano da época, que propõe ao leitor um city tour bizarro pela cidade, ou, por outra, pela cidade de Weegee.

Oferecendo-nos a possibilidade de uma visita guiada (com direito a "áudio" simultâneo, papel desempenhado pelo texto e legendas que acompanham as imagens), que se inicia ao sabor do que promete ser um certo tipo de entretenimento mas que de imediato se prova uma viagem mais que perturbadora, Weegee nos desorienta em inúmeras frentes. O sabor final do passeio é um estado de estranhamento geral. Mas poderíamos mesmo chamálo de "passeio"? Houve, no passar das páginas, o esboço de algum riso; entretanto, no cômputo geral, as expectativas iniciais de entretenimento dos viajantes foram todas frustradas. Em alta velocidade, arrastados por um turbilhão, entre solavancos e cotoveladas, descobrimos uma cidade distópica na qual imperam a desordem e a comoção social. Re-visitamos lugares que nos parecem familiares, embora diversos daqueles há pouco vistos. Variedade e repetição do mesmo têm fronteiras tênues. Em movimento espiralado, figuras aparecem e reaparecem em formatos distintos, como próteses de identidade no picadeiro de um circo macabro onde representam seus números cotidianos. Uma atmosfera de pesadelo urbano finalmente inunda o viajante. Azedadas nossas esperanças de diversão, ao menos na acepção mais corrente do termo, sentimos inicialmente o gosto acre de um "salve-se quem puder" generalizado; dele logo decorre outro dissabor: o que deveria servir ao propósito de melhor 
conhecimento dos pontos turísticos daquele terreno urbano parece ter causado precisamente o efeito oposto. Nossos referenciais, estruturalmente abalados, não nos permitem reconhecer a cidade nos termos em que suspeitávamos que o faríamos; nenhum cartão postal ou vista edificante nos é oferecido. Tudo é instável, insólito e nos foi tornado estrangeiro; da experiência resta um estado inicial de acedia, logo substituído por uma compreensão atônita, a sensação de acesso a um outro tipo de conhecimento, de natureza e magnitude distintas. E que conhecimento é este? Para aqueles que corajosamente se aventurarem a refazer o percurso proposto por Weegee, Naked City cumpre o que promete logo no título: desnudar a cidade de modo insuspeitado.

Gostaria de salientar que o livro é riquíssimo e que portanto constitui material suficiente para uma tese de doutoramento que contemple seus mais diversos assuntos e tratamentos dispensados, considerando-os em maior profundidade. Não é o caso deste capítulo, que se propõe apenas a apresentar o fotógrafo para o público brasileiro, informando o contexto que possibilita seu surgimento, aproximando sua produção fotográfica de uma determinada tradição de representação da experiência do oprimido, em primeiro lugar aquela que se consolida com a concepção e articulação de um sistema visual e pictórico desenvolvido pela pintura moderna na Paris do século XIX, de Courbet a Manet e, em seguida, pelo grau de parentesco que guarda tanto com a posição hierárquica subalterna ocupada no mundo do trabalho quanto com a obra do fotógrafo francês Eugène Atget, tributária, por sua vez, das mesmas conquistas da pintura francesa anteriormente mencionada. Nestes termos, ao abordar 0 primeiro livro de Weegee pretendo explorar somente um dos múltiplos aspectos presentes em Naked City, a saber, o poder de revelação dos procedimentos formais utilizados pelo autor na concepção de algumas imagens, na montagem para elas proposta e na utilização dos textos e legendas que as acompanham ao retratar o universo do trabalho no e a partir do mundo da indústria da notícia e do espetáculo. 
Para despir sua Nova York e, a partir do que o fotógrafo nos permite enxergar, arriscar possíveis respostas às indagações acima, proponho inicialmente um itinerário por parte de sua biografia, de fundamental importância para compreender alguns dos porquês das escolhas dos assuntos, da abordagem utilizada e do método de trabalho do fotógrafo. Em seguida, examinaremos as demais estruturas sobre as quais se assentam as bases de Naked City, ou seja, a constelação de fatores que permitiram a expansão, organização e consolidação de aspectos da formação "intelectual" ou "artística" e profissional que Weegee já trazia consigo, porém de modo menos sistematizado. Refiro-me a duas matrizes centrais: seu trabalho para o tablóide nova-iorquino PM Daily, "o órgão mais bem sucedido da Frente Popular em Nova York"5, e a primeira exposição fotográfica que fez no espaço de uma cooperativa de fotógrafos amadores e profissionais, a Photo League. De posse deste material, nos debruçaremos finalmente sobre algumas das questões suscitadas por seu primeiro livro.

Vendedor ambulante de jornais, comerciante de doce em porta de escola, fotógrafo ambulante, trabalhador em fábrica de embalagens, empregado em restaurantes de fast food, fotógrafo de passaporte, músico em salas de cinema, vendedor de guloseimas em teatros de variedade, assistente de fotógrafo profissional, aprendiz em redação de jornais e laboratorista. Weegee fez o que pôde para conseguir sobreviver em Nova York no início do século XX antes de se tornar "Weegee, the famous", o foto-jornalista bem-sucedido (e bemhumorado, pois era assim que "assinava" suas imagens mesmo quando era um ilustre desconhecido), capaz de cobrir inacreditáveis furos de reportagem antes de qualquer outro concorrente, não raro antes mesmo da própria polícia novaiorquina, e tudo graças aos supostos poderes para-normais que evocava para

${ }^{5}$ Cf. DENNING, M. op. cit. p. 16. 
justificar suas habilidades, rapidez e competência. Como foto-jornalista, seu trabalho Ihe rendia por volta de cinco dólares por fotografia vendida. Um pouco mais se a notícia fosse, como ele próprio costumava dizer, "quente", ou se a imagem parecesse particularmente interessante a algum dos jornais da cidade. Conseguia, assim, manter-se com um mínimo de conforto. Antes disso, passara por todo tipo de privação.

Quase tudo o que sabemos sobre Weegee provém de sua auto-biografia intitulada Weegee by Weegee, publicada em 1961 com o intuito explícito de promover seu personagem principal após anos de esquecimento. A infância pobre, as agruras do início profissional, o merecido reconhecimento, o suposto sucesso com as mulheres e por fim a consagração do Artista; tudo pintado com cores fortes e intensas à la Weegee para lembrar os mais jovens quem ele foi, e ainda era, e os mais velhos que o artista-fotógrafo estava bem vivo e mais ativo que nunca (o que não era verdade sob nenhum aspecto: seus problemas de saúde se agravavam e suas chances de conseguir emprego minguavam dia a dia). Ele termina assim sua peça de auto-propaganda:

"A vida agora é melhor que nunca! Há novos presidentes... reis... rainhas... aspirantes a estrelas... inimigos públicos... Alô? Alô? Quem fala? (se ao menos o telefone parasse de tocar...). Aqui é a Casa Branca... Aqui é o Palácio de Buckingham... Aqui é o diretor da prisão de Sing Sing... Aqui é Alcatraz. Ah, vocês querem fotografias? Têm hora marcada? Acho melhor levar minha máquina de escrever na bagagem (quisera eu que ela viesse com um mecanismo que pudesse escrever em inglês para mim), minha câmera e ir logo andando para... Paris... Londres... Berlim... Roma... Tóquio... Hong Kong... O mundo chama e eu estou chegando... 
Correspondência para mim? Aqui está meu passaporte, queridinha. Pode me chamar de Weegee." 6

O fotógrafo não é propriamente um narrador confiável. Mas, para além do caráter patético do excerto (Weegee se leva a sério demais durante todo o livro para pensarmos que fala de si mesmo com ironia distanciada - ele estava longe de ser, àquela época, o cidadão do mundo extremamente requisitado que o texto sugeria), uma coisa é certa: a inscrição na capa da edição original, logo acima do título, que define a personagem como "o fotógrafo mais anticonvencional, idiossincrático e excêntrico", num termo que não poderia estar mais distante do vernáculo inglês - the world's zaniest photographer - diz muito sobre quem foi o Weegee de Naked City.

Usher Fellig nasceu em 1899 na pequena cidade de Zlothev, nos arredores de Lemberg (antiga província austríaca da Galícia), mais tarde parte da Polônia (Zloczew) e hoje pertencente à Ucrânia (Lviv). A família judia administrava um pequeno negócio, uma loja de mantimentos e provisões, tendo o exército austríaco como maior cliente. Mudanças no governo local acarretaram consequências desastrosas para toda a comunidade judaica da região: violentos conflitos e campanhas anti-semitas forçaram ao êxodo inúmeras famílias. Os Fellig não foram exceção.

${ }^{6}$ Cf. FELLIG, A. Weegee by Weegee - an autobiography. Nova York: Ziff-Davis Publishing Company, 1961, p. 155.

7 A palavra zany, além do significado acima mencionado, está também historicamente relacionada ao mundo do espetáculo. Refere-se ao artista secundário que atua com palhaços, uma espécie de bufão subalterno que imita, deliberadamente de modo inapto, os trejeitos de seus parceiros de palco hierarquicamente superiores, magnificando, pela via do humor e da paródia, senão do sarcasmo e do escárnio, aspectos característicos de seu gestual e comportamento. A origem do termo encontra-se na França e na Itália do século XVI nas palavras zani (francês) ou zan(n)i (dialeto veneziano), referência à Gianni ou Giovanni, nomes utilizados pelos empregados menores em importância que atuavam como palhaços na commedia dell'arte. Conforme pretendo demonstrar adiante, as afinidades entre o termo utilizado e o papel desempenhado pelo Weegee de Naked City não são desprezíveis. 
Em 1906 o pai de Usher, Bernard, chega só aos Estados Unidos para tentar a sorte antes de trazer o restante da família. Após inspeção e seleção iniciais obrigatórias feitas por médicos e oficiais da imigração em Ellis Island, estabelece domicílio em Nova York. Lembremo-nos que qualquer suspeita de doença considerada grave ou incapacidade física visivelmente detectável, percebida como empecilho ao trabalho braçal, era passível de deportação imediata, o pior cenário para aqueles que chegavam à cidade. Uma vez superados a incerteza e o terror da deportação, Bernard, seguindo os passos de outros conterrâneos, ruma para o Lower East Side, região de Manhattan para a qual vinham sobretudo os irlandeses, italianos, alemães, poloneses, russos e outros imigrantes do leste europeu.

Vários deles viviam em cortiços verticais denominados tenement houses, enormes edifícios de cinco ou seis andares (que poderiam chegar a sete) divididos em minúsculos apartamentos destinados às famílias estrangeiras. As mais empobrecidas dividiam o mesmo espaço com outras, o que significava dizer que um único apartamento composto de quarto e sala - a cozinha e o banheiro eram comunitários - abrigava quatro ou cinco famílias, que não raro nem mesmo falavam a mesma língua. Conforme o passar dos anos, um pastiche de adereços seria incorporado às fachadas das novas construções que proliferavam na cidade (as primeiras datavam de 1832), como porte-cochères, batentes de janelas ou falsos lustres, na vã tentativa de sugerir distinção, inclusive em termos visuais: partes de um mesmo imóvel poderiam aparecer como vários edifícios ao olhar menos avisado, mascarando o que na verdade não era apenas um único cortiço vertical mas um super tenement, que poderia se estender por boa parte de um quarteirão. Seus moradores, no entanto, não se enganavam quanto às condições de sobrevivência por detrás de fachadas trompe l'œil. Neste ambiente, a disseminação de doenças era apenas mais um dos perigos iminentes. O mais temido, no entanto eram os frequentes incêndios. A estrutura física dos edifícios, composta por dutos centrais de ventilação e extenso uso de madeiramento, associada a métodos improvisados de 
aquecimento e preparação de alimentos que incluíam o armazenamento doméstico de querosene, gasolina e outros materiais inflamáveis, tornavam estes imóveis verdadeiras armadilhas, bombas incendiárias que poderiam explodir a qualquer minuto - o que de fato acontecia com assustadora frequência - mesmo quando novos, uma vez que eram construídos de modo apressado e com materiais de baixíssima qualidade (em teoria havia medidas reguladoras, completamente ignoradas na prática pelos proprietários dos imóveis ${ }^{8}$ ). Em questão de minutos um destes edifícios poderia ser reduzido a pó.

Morar em um deles não era, contudo, a pior opção: havia os moradores de rua ou, um pouco menos desafortunados, aqueles que se serviam dos dormitórios improvisados nos porões das delegacias de polícia. Inicialmente destinados às situações emergenciais, logo abrigariam em caráter permanente uma população inteira de indigentes, já que o que parecia contingente provara-se perene. $O$ próximo passo em escala ascendente eram hotéis baratos denominados flophouses, pardieiros imundos que ofereciam serviços variados conforme 0 poder aquisitivo da clientela: por vinte e cinco centavos, o cúmulo do luxo, o hóspede usufruía o melhor que a casa poderia the oferecer, a saber, uma cama de armar, um armário para guardar seus pertences (extremamente útil, porque qualquer objeto deixado à vista, de sapatos a dinheiro, provavelmente não sobreviveria até a manhã seguinte) e a privacidade fictícia oferecida por um biombo de tela. Quinze centavos pagavam pela cama e pelo armário, dez apenas pela cama, sete por algo parecido com uma rede puída e cinco por um

\footnotetext{
8 As leis nova-iorquinas de 1901 que regulamentavam a construção e manutenção destes edifícios serviriam de modelo para outras inúmeras cidades americanas - o processo de segregação dos pobres e exploração de sua miséria não era em absoluto privilégio da cidade de Nova York. O conjunto destas leis consistia essencialmente em medidas que estimulavam a construção de tenements pelo setor privado, que além dos lucros obtidos com a administração do imóvel, gozaria de incentivos fiscais e outros benefícios concedidos pelo Estado - uma aliança entre poder público e interesse privado. Na atmosfera de especulação imobiliária e construção desenfreada que decorre, nem mesmo as medidas mais elementares de segurança e higiene defendidas pelas posições mais abertamente reformistas seriam respeitadas. Cf. BOYER, M. C. Dreaming the Rational City - The Myth of American City Planning. Cambridge, Massachusetts: The MIT Press, 1983. Tanto o cinema como o teatro norteamericanos da primeira metade do século XX dedicaram obras de interesse que abordam tal questão. A esse respeito ver, por exemplo, One Third of a Nation (1939), de Dudley Murphy.
} 
lugar qualquer no chão, se ainda houvesse algum espaço disponível a ser disputado entre os miseráveis retardatários. Naturalmente, apenas os estabelecimentos mais distintos ofereciam todo este leque de alternativas. A escolha da freguesia normalmente se restringia às duas últimas opções 9 .

As pensões constituíam o próximo nível de conforto. Um trabalhador com emprego fixo e razoavelmente bem pago (o que era raro, pode-se imaginar) gastaria cerca de dois dólares por semana com o aluguel de um quarto e de três a cinco se as refeições estivessem inclusas. E finalmente, para a maioria dos imigrantes que chegavam a Nova York, o inimaginável pináculo do fausto era o aluguel de um apartamento para uma única família num daqueles tenements. $O$ sonhador teria que desembolsar entre vinte e cinco e cinquenta dólares por um apartamento de quatro ou cinco cômodos, mobiliário não incluso. Logicamente o preço variava segundo a localização do imóvel no edifício: os mais caros eram os mais claros e arejados, de frente para a rua, e em andares mais baixos, pela facilidade de acesso (e evacuação!). Mesmo assim, um apartamento de fundos em andar alto, pequeno e escuro, gélido no inverno e sufocantemente quente no verão, poderia custar a pequena fortuna de dez dólares mensais.

Inicialmente morando de graça com membros da família e amigos, o pai de Usher, um petit métier, logo começa a trabalhar no bairro como vendedor ambulante de utensílios domésticos durante o dia. À noite, ensina hebraico às crianças da redondeza preparando-as para seu bar mitzvah. Também substituía o rabino em várias congregações da região, trabalhando, quando possível, como cantor em casamentos e outras comemorações judaicas ${ }^{10}$. Mais tarde consegue o posto de síndico de um dos tenements locais, condição cobiçada pelo "privilégio" da garantia de emprego, abrigo e gratuidade no aluguel. Em 1910 tinha economizado o suficiente para poder trazer a família, esposa e quatro filhos. Para que conseguissem entrar no país, Bernard mostra às autoridades o

${ }^{9}$ Cf. SANTE, L. Low Life - Lures and Snares of Old New York. Nova York: Farrar, Strauss and Giroux, 1991.

${ }^{10}$ A representação do ofício não passou desapercebida no filme O cantor de jazz, de 1927. 
produto de suas economias, assegurando-lhes que a família não imporia qualquer ônus adicional ao Estado norte-americano.

Ao chegar nos Estados Unidos com dez anos de idade, Usher teve seu nome imediatamente americanizado pelos auxiliares da imigração, passando a chamar-se Arthur a partir de então. O que era estrangeiro deveria ser normatizado (o que equivale a dizer americanizado) e a política de imigração americana era clara: a entrada de imigrantes era, sim, necessária para a ampliação do contingente de trabalhadores. Mas o que aparecia como estranho ao país, sobretudo a experiência histórica européia percebida como radical e todas as suas formas de expressão, cuidadosamente inspecionadas pelos oficiais, deveria ser removida da bagagem dos aspirantes a cidadãos norteamericanos. Havia um código ético, moral e disciplinar a ser seguido e aqueles que entravam no país precisavam provar-se dignos das benesses que a América poderia oferecer-lhes, a elas submetendo-se. A palavra "usher" em inglês significa, como substantivo, aquele que indica o assento a ser tomado pelo visitante em um cinema, teatro ou evento esportivo. Como verbo, expressa a idéia de abrir caminho ou apontar para uma determinada direção ${ }^{11}$. No contexto em que se encontrava, Usher não guardaria seu nome, pois ali ninguém se chamava "lanterninha" e muito menos tinha voz ativa o suficiente para profetizar o curso dos acontecimentos ou apontar caminhos; "Usher" não passaria. À experiência de deslocamento forçado e estranhamento generalizado da criança soma-se aquela da expropriação no nível da própria identidade. Quanto às técnicas de sobrevivência no novo lar, começariam ali mesmo a serem desenvolvidas:

11 A palavra "usher" entra na língua inglesa a partir do termo francês "huissier" e está, historicamente, relacionada aos servos de cortes que tinham a função subalterna de receber os visitantes ou informar-lhes a saída nos palácios de monarcas ou nobres de poder. Daí a idéia de abertura de caminho, encerrada também no significado do nome próprio Usher (pronunciado AESHER), que em hebraico significa, além de "abençoado", também "profeta". Na Bíblia, Asher (uma das variações mais comuns de "Usher") é um dos ancestrais das doze tribos de Israel. 
"Em Ellis Island, que parecia o lugar mais lindo da terra, os agentes sanitários da imigração nos inspecionavam minuciosamente. Verificavam sobretudo nossos olhos. Um homem gentil me deu uma banana e uma laranja. Eu não sabia o que fazer com aquilo porque jamais tinha visto algo parecido com uma banana ou uma laranja em Zlothev. $O$ homem cuidadosamente descascou a banana para mim. Comê-la ficou por minha conta. Era bom... como... era bom, não sei como o que, mas era bom! Imaginei que se a banana deveria ser descascada a laranja também, e assim eu mesmo a descasquei. A laranja também era boa."12

Em seu primeiro ano na cidade a família viveu numa série de edifícios do Lower East Side, mudando-se com frequência, até finalmente estabelecer domicílio num apartamento sem aquecimento de três cômodos (o banheiro no final do corredor era comunitário e servia a outras três famílias) no quinto andar de um tenement em Cherry Street ${ }^{3}$.

"Logo o carrinho ambulante de meu pai rendeu frutos e nos mudamos para outro edifício sem aquecimento, desta vez em Cherry Street, perto da zona portuária. Tínhamos três cômodos no quinto andar - uma boa subida! Havia um banheiro para quatro famílias. Como papel higiênico, nós, as crianças de lá, usávamos o Journal [Journal American], de Hearst... Tinha os melhores quadrinhos, o Katzenjammer Kids, Abe Kabbible, Happy Hooligan. [...] E não havia aluguel para pagar, já que meus pais eram síndicos. Eles limpavam e

12 Cf. FELLIG, A. op. cit. p. 9.

${ }_{13}$ Quanto mais longe do rio Hudson, maior era o prestígio do endereço nova-iorquino, uma vez que a região portuária era feia, suja e perigosa. Os ricos residiam no norte de Manhattan, em diversas áreas de Uptown e os pobres no Lower East Side. A parcela mais miserável entre os miseráveis morava nas áreas do Lower East Side mais próximas ao rio. Cherry Street é uma das ruas desta parte da cidade. 
esfregavam as escadas, colocavam o lixo para fora e brigavam para receber 0 dinheiro do aluguel para 0 proprietário, que jamais estava em dia." ${ }^{14}$

Logo que chega, Arthur é matriculado na escola local e vai estudar na classe dos estrangeiros que aprenderão inglês como segunda língua. $\mathrm{Na}$ linguagem popular, esta classe era conhecida como greenhorn class, ou seja, uma classe para "inexperientes". O termo também se refere, pejorativamente, a uma pessoa em geral do sexo masculino, ingênua o suficiente para ser ludibriada. Era assim que as outras crianças se referiam aos integrantes desta classe. Arthur, que adorava línguas (o garoto já falava polonês e alemão), tinha portanto motivações extras bastante concretas para aprender o idioma local: minimizar 0 menosprezo, inserir-se no grupo do qual tentava fazer parte (e que não parecia dar indícios concretos de possibilidades para a confraternização) e finalmente não se deixar lograr pelos colegas. Em suma, era uma questão de sobrevivência. O esforço do aluno deveria ser redobrado, pois as línguas oficiais do gueto judeu de Manhattan eram ídiche, russo, polonês, e alemão, o que restringia significativamente as oportunidades de prática do novo idioma para todos que se encontravam em condição semelhante à do garoto. Depois de dois anos, conseguiu ser transferido para uma turma regular, um feito notável consideradas as adversidades. Não ficaria, contudo, muito tempo na escola. A experiência escolar provara-se mais um exercício de humilhação que uma oportunidade de aprendizado real. Além do mais, as necessidades materiais eram de tamanha ordem que poucos filhos de imigrantes passavam muito tempo nos bancos escolares. Para eles, evasão era apenas uma questão de tempo.

"Tinha quatorze anos e estava na sétima série ' $A$ ' quando informei à diretora que deixaria a escola e queria meus certificados escolares. Ela insistiu para que eu terminasse o

${ }^{14}$ Cf. FELLIG, A. op. cit. pp. $9-10$. 
curso, mas eu não queria esticar a agonia por mais um ano e meio. Estávamos desesperadamente necessitados e eu precisava trabalhar - e rápido!"15

Mas Arthur já trabalhava antes mesmo de deixar a escola. Seu primeiro emprego foi o de vendedor de jornais pelo bairro, ou, como eram conhecidos na época, newsboys ou newsies (o fotógrafo norte-americano Lewis Hine os documentaria extensamente; o garoto poderia inclusive ter sido objeto de suas imagens). A primeira ocupação não durou sequer uma semana: logo descobriu que a enorme maioria dos habitantes locais não lia em inglês. Começou então a vender doce após as aulas para as crianças das proximidades. Perambulava pelas ruas procurando fregueses, percorria as sweatshops locais e obtinha algum lucro comprando e vendendo a crédito - quando ele próprio não comia boa parte da mercadoria. Para estas crianças, a possibilidade de conseguir algum trabalho poderia determinar a continuidade de sua existência física.

Nenhuma família abaixo do que era considerado classe-média podia arcar com as despesas de um membro com mais de doze anos. Poucas podiam mantê-los para além dos oito e a enorme maioria encontrava dificuldades para atender até mesmo as necessidades dos recém-nascidos. O estatuto da infância, como concebido atualmente para uma minoria da população, simplesmente não era uma realidade no cotidiano destas crianças. O senso comum era que deveriam prover os meios de sua subsistência e desaparecer das vistas dos maiores, desempenhando tarefas que exigiam responsabilidades semelhantes às dos adultos, sem, naturalmente, contar com sua força, experiência ou poder de autodefesa. Muitas eram presa fácil de gangues infantis (algumas delas notórias pela truculência com que agiam; seus membros atuavam de modo rigorosamente idêntico às gangues de criminosos adultos, exceção feita à convocação para o voto repetido em eleições fraudulentas) ou da mendicância organizada nos termos do business, um pastiche da suposta ordem, lei e progresso oferecidos

${ }^{15}$ Cf. FELLIG, A. op. cit. pp. $13-14$. 
pelo Novo Mundo (o negócio era regido de modo organizado e respeitava a hierarquia e o organograma concebidos pelo chefe; seus membros eram devidamente educados em escolas especializadas, as chamadas fagin schools, e dependendo do desempenho e do lucro proporcionado, ascendiam a postos de maior responsabilidade e confiança. Este contexto seria descrito também em Londres por Dickens e em Berlim por Brecht). A última opção contemplada pelas crianças era o emprego formal, literalmente sinônimo de trabalho escravo. Circulando na mais baixa esfera do submundo, tinham sorte quando passavam desapercebidas. Seu status não era significativamente distinto daquele dos animais.

Distante dos bancos escolares e com mais tempo para trabalhar, Arthur fazia qualquer coisa que the rendesse algum trocado em vários empregos simultâneos: assistente de fotógrafo em estúdio, fotógrafo ambulante e vendedor de doce em teatros de variedades na região da segunda avenida. Enquanto isso, estudava música avidamente. Comprara um violino de segunda-mão com as reservas que tinha economizado e tomava aulas num tenement que the custavam vinte e cinco centavos de dólar por hora, um investimento considerável para quem trabalhava de olho na próxima refeição. Chegou mesmo a integrar a orquestra do cortiço. Arthur sabia, entretanto, que a atividade não poderia ser apenas um passatempo, luxo a que de fato não poderia se dar, mas um outro meio de conseguir emprego e ampliar suas possibilidades de ganho.

"Praticava com frequência [o violino] e agora, de repente, tinha a chance de tocar de verdade. Encontrei um músico em um cinema da Terceira Avenida que concordou em me dar aulas particulares gratuitas se eu o ajudasse a fazer gim caseiro [bathroom gin] e o entregasse a seus sedentos clientes. Logo estava ajudando-o no cinema também. Meu professor acabou por ficar tão ocupado com seu segundo emprego que desistiu do cinema. Neste momento eu já era 
bom o suficiente para substituí-lo. Também substituí a garota do piano." 16

Neste momento Arthur já havia saído da casa de seus pais - não se sabe ao certo se aos quinze ou dezoito anos de idade. E continuar a comer apenas de vez em quando, dormindo em parques públicos no verão (Bryant Park) e em estações de trem no inverno (Grand Central Station e Pennsylvania Station) ou, na melhor das hipóteses, passar temporadas em flophouses do Lower East Side, não estavam em seus planos futuros. Membro da segunda geração da segunda leva de imigrantes que chegara aos Estados Unidos em busca de novas oportunidades, o garoto confronta-se, por um lado, com as memórias e histórias de seus pais e a dura realidade das ruas da cidade. Por outro, depara também com uma situação bastante peculiar no universo do trabalho, a saber, a gigantesca expansão das indústrias culturais norte-americanas a partir dos anos vinte, a decorrente proletarização da produção cultural e as novas formas e oportunidades de participação e intervenção da classe trabalhadora no universo da produção da cultura e das artes. Como milhares de trabalhadores em condições semelhantes, Arthur encontrará nas relações entre o moderno aparato cultural (do entretenimento de massa e das possibilidades de educação e treinamento intelectual) e as poderosas forças democráticas de um movimento social em desenvolvimento e consolidação, a Frente Popular, as condições não apenas para sua subsistência mas a possibilidade de contribuição, com voz ativa, para a realização - ainda que simbólica e temporária - de um sonho social coletivo, expresso e traduzido na forma de um "novo" modernismo, ou, se preferirmos, de um "simbolismo revolucionário"17. Estamos, portanto, distante do campo da genialidade individual. Será do encontro entre as formas de uma determinada experiência social e um certo procedimento estético, depoimento crítico sobre tal experiência, que se criará uma estrutura de sentimento em Naked City.

${ }^{16}$ Cf. FELLIG, A. op. cit. p. 27.

${ }_{17}$ Cf. DENNING, M. op. cit. p. 29. 
Nestes termos, um acúmulo inicial significativo de experiências biográficas se faz notar, produzindo os resultados catalíticos que liberam e aceleram as primeiras vagas de energia que sucessivamente transformarão Arthur Fellig em Weegee. Forma-se, então, o primeiro ponto nodal no eixo do sistema centrado em Naked City: à experiência do garoto no novo país adiciona-se, pelos imperativos do mundo do trabalho, sua vivência como músico em cinemas de Nova York, seu contato com formas oriundas da cultura popular, mais especificamente o teatro de variedades, o chamado vaudeville e, de par com estas, o princípio do desenvolvimento técnico - pautado por uma relação social - de sua prática fotográfica, ofício que, como veremos, melhor permitirá sua subsistência.

Por volta de 1924 o jovem Arthur tentava sua sorte, como vimos, em várias frentes. Trabalhava simultaneamente numa série de empregos muito díspares, em meio período, desempenhando inclusive o ofício de músico em cinemas que exibiam filmes silenciosos. Para isso expandira suas habilidades - aumentar suas chances de empregabilidade e ganhos e, consequentemente, garantir seu sustento. Não sabemos ao certo onde tocou e quais os filmes que acompanhou ao violino, mas certamente boa parte de sua cultura visual é proveniente das películas a que assistia enquanto trabalhava - e também de todas as outras que via como fã, inclusive quando já não mais atuava como músico (Hollywood sempre exerceu enorme fascínio e influência sobre Weegee, que encarava seu contato com o cinema como forma de trabalho, de diversão ou, segundo ele próprio, uma espécie de abrigo para descansar ou dormir entre uma tarefa e outra). Deve ter visto um pouco de tudo. Por seus relatos, inferimos que dentre os filmes com os quais travou contato constam sobretudo os explicitamente comerciais, com enredos concebidos para agradar o grande público e arquitetados a partir da rigorosa estrutura preceituada pela indústria 
cinematográfica. Inclusos no receituário: 1. o encadeamento causal de uma ação que se apresenta como linear, 2. a atuação exagerada e/ou artificial dos atores, incluindo a fala e diç̧ão, com intuito de suscitar a empatia ou antipatia do público, buscando modos a partir dos quais a platéia se identifique com os temas ou personagens representados, 3. o consequente envolvimento destes espectadores cativos da trama numa teia de emoções que se esgotavam em si mesmas, 4. a caracterização "realista" das personagens (com observação estrita do physique de l'emplol), 5. a distinção marcada entre heróis e vilões, 6. as tensões previstas no enredo que visam os desfechos apoteóticos e 7. a ratificação prescritiva de determinados papéis sociais ou atitudes comportamentais, "naturalizados" pelo filme, que deveriam ser observados e emulados pela platéia - no limite, uma "cartilha" (por exemplo, a valentia masculina e a sensibilidade feminina eram comumente apresentadas como características naturais e inerentes aos gêneros correspondentes e que, portanto, deveriam fazer parte da formação ou dos traços de personalidade de seus membros). Em breves palavras, tratava-se de filmes que pretendiam sancionar determinados modos de concepção de mundo, aqueles relativos à esfera burguesa; aqui, "ensinar" equivale à tentativa de "treinar ideologicamente" num processo de manipulação mascarada, inclusive em seus termos visuais e estéticos. Ao lamentar a introdução do som no cinema, Weegee menciona de modo abertamente apreciativo filmes de natureza semelhante aos acima descritos:

"Quem quer falatório no cinema? Você vai ao cinema para sonhar e escapar e não para escutar monólogos. Hoje em dia o herói, que tem representado papéis juvenis nos últimos quarenta anos, ajusta sua peruca e seu zíper e resmunga: 'Querida, se eu a amo, ah, se não! [Darling, I do love you, rahlly18 I do]. A mocinha, que recusa ceder (ela deveria estar

18 Weegee imita, em sua recriação ortográfica da palavra "really", a variante oral de uma pronúncia afetada e artificial, marcando a distância entre o filme e o universo de seus 
representando o papel da avó) desfalece [swoons] em seus braços. Quanta bobagem! Se devem falar, que o façam nas pantomimas. Nos velhos tempos, os filmes eram melhores do que nunca. A maioria dos cinemas eram lojas transformadas em salas de exibição. As novas tinham até teto retrátil que podia ser aberto no verão, o ar-condicionado daquele tempo. Ao invés de irem ao psicanalista as pessoas iam ao cinema, que preenchia os espaços vazios em suas almas. A minha música ajudou a preenchê-los até a boca."19

Weegee reconhece - e valoriza - a índole de sonho e escapismo que domina a produção cinematográfica com a qual teve contato, identificando o caráter manipulador nela tão presente, cujo intuito seria "preencher o vazio da alma". Como consumidor passivo deste tipo de mercadoria, pôde aderir, de modo simpático e "voluntário", sem extrair maiores consequências, à idéia de que o cinema serve de fato a este propósito. Porém como músico trabalhador da indústria do entretenimento sujeito às imposições concernentes ao mundo do trabalho, logo depararia com modos alternativos de subversão (ou, como veremos adiante, de total reversão) dos usos correntes para os efeitos que aprecia, por oposição, o mero consumidor, alvo daquela mercadoria. Compreendeu, nos termos mais práticos, que mesmo em sua restrita área de atuação ou, por outra, precisamente porque circula num dos estágios hierarquicamente mais subalternos e periféricos é que deverá, impreterivelmente, acomodar-se em todos os momentos a cada modificação imposta pelo ritmo e/ou pelo modo de produção. Portanto, ele deveria antes de qualquer coisa compreender profundamente o significado do termo "ajustar-se", o que, para o jovem Weegee, não seria algo propriamente alheio à sua experiência.

espectadores na referência ao modo como imaginava que as classes dominantes, representadas na figura do artista de cinema, pronunciariam o termo ressaltado (meus grifos).

${ }^{19}$ Cf. FELLIG, A. op. cit. pp. $27-28$ (meus grifos). 
De imediato atinou para o fato de que "ajuste" poderia significar inclusive "adaptação" e "intervenção". Como músico, sua tarefa profissional consistia em colaborar, da maneira mais eficaz possível, para o preenchimento do "vazio das almas" que pagavam pela mercadoria que haviam comprado, ou seja, o filme que assistiam. A repetição contínua e idêntica da mesma tarefa, ou seja, a execução da mesma trilha sessão após sessão em conformidade com cada uma das cenas que se the apresentava contínua e ininterruptamente, aliada à restrita liberdade que gozava para introduzir pequenas variações na execução do trabalho, dependendo do público para o qual tocava, determinam as vias que conduzem tanto ao aperfeiçoamento contínuo de suas funções como da técnica por ele utilizada, incluindo possíveis modificações, re-adequações do material ou modos de articulá-lo que melhor atendessem às necessidades ou desejos específicos das mais distintas platéias. De seu ponto de vista, aperfeiçoar seu desempenho e habilidades técnicas significava evitar a obsolescência e, nos termos mais comezinhos, garantir mais um dia de emprego. Ora, não é este o estatuto do operário numa linha de montagem? Como nos lembra Walter Benjamin:

"A técnica submeteu, assim, o sistema sensorial a um treinamento de natureza complexa. Chegou o dia em que o filme correspondeu a uma nova e urgente necessidade de estímulos. No filme, a percepção sob forma de choque se impõe como princípio formal. Aquilo que determina o ritmo da produção na esteira rolante está subjacente ao ritmo da receptividade, no filme.

Não é em vão que Marx insiste que, no artesanato, a conexão entre as etapas do trabalho é contínua. Já nas atividades do operário de fábrica na linha de montagem, esta conexão aparece como autônoma e coisificada. A peça entra no raio de ação do operário, independentemente de sua vontade. E 
escapa dele da mesma forma arbitrária. 'Todas as formas de produção capitalistas... - escreve Marx - têm em comum o fato de que não é o operário quem utiliza os meios de trabalho, mas, ao contrário, são os meios de trabalho que utilizam o operário; contudo, somente com as máquinas é que esta inversão adquire, tecnicamente, uma realidade concreta.' No trato com a máquina, os operários aprendem a coordenar 'seu próprio movimento ao movimento uniforme, constante, de um autômato'. [...] Seu comportamento é uma reação a choques." 20

No seio de uma vivência eminentemente urbana e moderna, aquela do choque, Weegee inicia uma série de tentativas ou "experimentos", a saber, a execução de sucessivas variações musicais àquelas prescritas pela trilha recomendada para o filme.

\begin{abstract}
"Eu adorava manipular a emoção da platéia enquanto assistia aos filmes silenciosos. Poderia levá-los da felicidade à tristeza. Tinha a meu dispor toda uma gama de possibilidades para qualquer situação. Suponho que tocar violino foi um treinamento subconsciente para minha futura prática fotográfica. Mais tarde, as pessoas me diriam com frequência que minhas imagens as emocionavam profundamente, levando-as do riso às lágrimas." ${ }^{21}$
\end{abstract}

A observação atenta das cenas que adentram seu campo de visão em conjunto com a rigorosa apreciação das diversas reações da platéia a cada momento durante o filme informavam e determinavam todas as possíveis modificações ou

20 Cf. BENJAMIN, W. Sobre alguns temas em Baudelaire. In Obras escolhidas III - Charles Baudelaire, um lírico no auge do capitalismo. São Paulo: Editora Brasiliense, 1994, pp. 125 126.

${ }^{21}$ Cf. FELLIG, A. op. cit. p. 27. 
variações a serem introduzidas (ou suprimidas) num fluxo incessante de trabalho e observação que transitava por dois pólos, o filme e a platéia. Os resultados de cada uma destas experiências encerram significado e acumulam-se para formar o corpo que permite a dilatação quantitativa e qualitativa da latitude do repertório técnico que o músico terá à sua disposição, ajustando-se assim com maior proficiência e flexibilidade às exigências mercadológicas que lhe são feitas.

A partir da avaliação das experiências que realizou, Weegee concluiu que a música que tocava não precisaria necessariamente subordinar-se sempre aos estímulos visuais que recebia a platéia, conforme a régia imperial de uma ordem visual ou musical concebida hierárquica e/ou aprioristicamente. Ela poderia ascender à categoria de mais um elemento central na composição da obra e na criação do efeito geral (por ele) desejado, tornando-se, no limite, um comentário pertinente para a ação ou, mais especificamente, um gesto socialmente relevante. Assim, no caso da música, uma determinada nota ou acorde, que numa certa situação poderia representar algo banal ou corriqueiro, noutra, modificada segundo os interesses ou ponto de vista de seus produtores, adquire status de significação, com valor protuberante e superior à primeira, ratificando, contradizendo, re-contextualizando, enfim, interagindo significativamente com outros elementos que compõem a fatura desta obra em nível semelhante de importância. Esboçam-se aí novas possibilidades artísticas para o jovem Weegee: a partir de um modelo estático, iniciam-se os processos que forjarão, paulatinamente, um novo sistema; este, dinâmico em sua natureza, se posicionará frontalmente contra qualquer esquema engessado ou modos passepartout de representação artística, fazendo face ao conceito objetivado e fetichizado de forma. E cada "ruído" adicionado ao primeiro contribuirá para a consolidação do segundo, até que, finalmente, os automatismos da percepção fetichizada da platéia sejam estruturalmente abalados por uma ordem qualitativamente superior que eleva seu gosto, inicialmente através da sensação de estranhamento e, em seguida, pela necessária e contínua investigação exigida do observador, aqui alçado à categoria de espectador inteligente porque 
ativo. Noutros termos, a ruptura com a estética dominante de cunho prescritivo desafia o público que, a partir de novas formas de organização do material que se Ihe apresenta, deverá estabelecer as devidas mediações para coligar elementos que outrora apareciam como fragmentos autônomos. No novo universo, o que aparecia como tal torna-se uma "personagem completa" ou um "todo" na forma de fragmento, que sem a obrigatoriedade de submeter-se à linearidade imposta pela narrativa tradicional, ganha vida para contribuir significativamente para a armação e demonstração de processos, como num mosaico ou painel. O alvo do novo sistema será, portanto, alcançar a essência dos processos que pretende descrever.

Representante de um coletivo de trabalhadores que percebe o desajuste sintomático da posição marginal que ocupa em relação à cultura dominante, Weegee utiliza suas experiências para a ampliação e a articulação das formas artístico-fotográficas que demonstrarão a superioridade do ponto de vista do trabalhador-produtor sobre aquele do mero receptor-consumidor. É este o ponto de vista que melhor informará, por exemplo, as condições de trabalho dos fotógrafos (mas não apenas destes!) dentro de determinadas relações sociais de produção na cidade que será desnudada, revelando a proletarização generalizada de todos os trabalhadores e, no limite, como veremos adiante, o grau das possibilidades de figuração e problematização das relações entre as condições de produção cultural e os imperativos do mundo do trabalho no universo político do período. Nestes termos, aquilo que poderia parecer uma escolha pessoal, arbitrária e estética do Artista é, no mundo do trabalho, uma exigência da hora histórica, do local social e do papel que desempenha este trabalhador nas relações de produção. E, não menos relevante, é este o ponto a partir do qual se poderão conceber novos modos de concepção e fruição do trabalho e de seus frutos (incluso o trabalho artístico), que por suprassunção denunciará o trabalho alienado como tal a partir de concepções de formas de trabalho não-alienadas. Nesta atmosfera ruirá toda e qualquer idéia de diversão como sonho escapista, que não apenas sonega conhecimento mas produz 
obscurantismo. Tomará seu lugar uma prática que aproximará o que aparece como separado mas não como separado, que iluminará as facetas obscurecidas do objeto "estudado" e que solicitará o olhar do observador para todo e qualquer "ponto cego", buscando deste modo o desenvolvimento das capacidades de percepção crítica.

Mas em breve o músico Weegee seria atropelado pelo desenvolvimento da indústria cinematográfica, que a partir da introdução do som no cinema com o clássico O cantor de jazz (1927) tornaria redundante um aglomerado de trabalhadores que incluiria, além dos músicos, profissionais das mais diversas áreas como técnicos, atores e diretores ${ }^{22}$ (pensemos, a título de exemplo, nos casos de Buster Keaton e Eric von Stroheim $\left.{ }^{23}\right)$. A massa de desempregados resultante desta avalanche deveria se ajustar às novas mudanças buscando abrigo em outras atividades. Weegee o faria na fotografia, meio no qual já se encontrara. Das experiências que vivenciara como trabalhador, deve ter logo intuído que sua condição de operário não-especializado o tornava por demais vulnerável a qualquer movimento brusco no universo do trabalho; era um representante do trabalhador mais profundamente degradado, a cada momento lembrado de sua condição. Ao avaliar suas possibilidades de sucesso, concluiu que a fotografia seria sua aposta menos arriscada, possivelmente a única. Mas a experiência como músico de cinema talhara-lhe na memória marcas por demais profundas que não seriam facilmente descartadas. E, como veremos, sua obra fotográfica as incorporará: sonho, escapismo, música, comentário, manipulação, combinação de gêneros, explicitação dos pontos de vista, fragmentação e ruptura de convenções serão, nos termos acima descritos, ingredientes fundamentais que encontrarão sua forma mais bem-acabada em Naked City.

\footnotetext{
22 Para uma descrição detalhada deste processo, ver COOK, D. A. A History of Narrative Film. Londres e Nova York: W. W. Norton \& Company, 1996.

${ }^{23}$ Este seria um tema central do filme Crepúsculo dos Deuses (Sunset Boulevard; 1950), de Billy Wilder, não por coincidência com a presença de Keaton e Stroheim, entre outros descartados pela indústria cinematográfica.
} 
A oposição entre "espetáculo sério" e "entretenimento" (leia-se "programa de pobre") já era um fato consumado na vida cultural de Nova York pelo menos desde 1830. Geograficamente, o primeiro tinha assento na Broadway enquanto o segundo espalhava-se pela cidade mas concentrava-se sobretudo numa das ruas mais populares do sul de Manhattan, the Bowery, a anti-Broadway par excellence. Enquanto uma representava essencialmente 0 teatro burguês frequentado por le tout New York (embora nem sempre tenha sido assim: a Broadway era, em seus primórdios, uma rua de atrações populares) a outra significava diversão para a classe trabalhadora, a quintessência do "circo das massas", e por "circo" entendam-se atrações circenses e burlescas, cinemas, cabarés, gabinetes de curiosidades (os chamados dime museums) e, além de bares e restaurantes populares, os teatros de variedades.

Após sucessivas tentativas frustradas de competir com os espetáculos em cartaz na concorrente, com intuito de firmar-se como alternativa a esta e, quiçá, suplantá-la em qualidade (naturalmente nos termos em que o conceito de "qualidade" era concebido) mas sobretudo em faturamento, The Bowery finalmente se constitui como uma rua de arte proletária feita pelo e para o proletariado, uma espécie de "Bulevar do Crime" nova-iorquino. Em seus tempos áureos, entre 1840 e 1850, seus membros tinham voz ativa no que dizia respeito aos integrantes que comporiam os espetáculos, bem como o tipo de produção que deveria ser apresentada nos teatros, como em Beulah Spa e Two of the $B$ 'hoys, peças que incorporavam alguns dos frequentadores assíduos do local à narrativa ou $A$ Glance at New York e New York as It Is, que pretendiam investigar a vida na cidade do ponto de vista dos habitantes locais "como ela era".

Contudo, a rápida consolidação da indústria do espetáculo na cidade, chancelada por turnês de artistas já publicamente consagrados no universo do 
teatro "sério" com a grife de uma Sarah Bernardt, e a transformação de escritores em produtores artísticos e/ou donos de teatros (August Daly, David Belasco ou Henry D. DeMille), que expandiam e diversificavam seus negócios, não deixava alternativa a Bowery senão a decadência. Por volta dos anos noventa do século XIX era claro que a vida cultural da rua encontrava-se moribunda e não resistiria muito mais, não fosse a chegada de novas forças, com seus próprios talentos, platéia e repertório. Uma delas era o Yiddish Theater, com produções que desde 1889 tinham lugar na Bowery, primeiro com a encenação de clássicos como Shakespeare ou Ibsen, mas que logo traria montagens de peças escritas pelos próprios membros dos diversos grupos que proliferavam na cidade (como The Wild Man e God, Man and the Devil, de Jacob Gordin). Não raro, a comunidade local de imigrantes somava forças para auxiliar na arrecadação de fundos permitindo que companhias estrangeiras se instalassem na cidade e seus espetáculos pudessem ser encenados (dentre alguns dos casos mais famosos, a ajuda organizada por Emma Goldman para receber e instalar a companhia russa de Paul Orleneff e Alla Nazimova num teatro da rua $31^{24}$ - o que significava, em termos práticos, a expansão geográfica e ideológica das fronteiras de atuação dos grupos, do sul do Lower East Side rumo ao norte de Manhattan).

O outro fator responsável pela sobrevivência da Bowery como centro de cultura popular foi a consolidação no local do teatro de variedades, o vaudeville. $\mathrm{Na}$ verdade, ele existia como atração em vários pontos da cidade. No entanto, encontraria aqui uma situação privilegiada para seu (re)florescimento. Graças a leis criadas ou ignoradas por grupos ou líderes locais influentes, os teatros operavam sete dias por semana, o que em si já configurava uma infração a disposições estabelecidas pelas autoridades responsáveis (que elegantemente as ignoravam mediante acordos distantes de quaisquer códigos legais ou éticos). Seu público era majoritariamente pobre, composto por norte-americanos e imigrantes da região. Não raro viviam no limiar da miséria e faziam qualquer

${ }^{24}$ Cf. SANTE, L. op. cit. 
coisa para garantir sua sobrevivência - o que não excluía o trabalho nestes mesmos teatros ou, sempre que a oportunidade se apresentava, a prática de todo tipo de trambique e contravenção. Todos pareciam circular, em suma, por uma zona limítrofe entre a lei e o delito, a ordem e a desordem, sem muitos meios-tons entre um extremo e outro. A rua tinha mais uma significativa vantagem sobre os outros locais da cidade: contava com os resquícios da tradição e memória populares, pois o gênero nascera ali por volta dos anos quarenta do século XIX com espetáculos que incluíam números de menestréis, mágica e ventriloquia, portanto desde o princípio uma arte de cunho essencialmente popular, já que dela ausentes as referências alegóricas aos sistemas hegemônicos da alta-cultura.

Aos poucos estes números seriam incorporados às peças encenadas nestes teatros (normalmente melodramas), nunca como parte de seu enredo ou narrativa, mas como números menores de diversão ligeira, portanto inferiores hierarquicamente, nos intervalos dos espetáculos principais. Começariam a ganhar cada vez mais espaço e representatividade porque as platéias se identificavam, de forma bastante direta, com seus assuntos, temas, tipo de humor e modos de concepção e encenação. Não tardou até que dois terços do programa de um estabelecimento típico consistisse de quadros característicos do teatro de variedades. Por volta de 1900 já somavam cem por cento do programa em casas a eles especialmente consagradas, como o famoso Miner's. Os números aqui apresentados eram variados, compostos por equilibristas, malabaristas, dançarinos, comediantes, músicos, cantores adultos e mirins (em geral newsies, que rapidamente conquistavam a simpatia da platéia), atores, declamadores de poemas, beldades em trajes sumários, e, dentre tantos outros, artesãos que demonstravam suas habilidades manuais, como modelar argila ou algo semelhante ${ }^{25}$. A sequência dos quadros não tinha, necessariamente, uma ordem pré-estabelecida e suas ligações não respeitavam as convenções da narrativa tradicional do drama burguês, em grande parte pelos próprios ritmos da

${ }^{25}$ Cf. SANTE, L. op. cit. 
imprevisibilidade e improvisação impostos à sobrevivência física de seus participantes e, por conseguinte, às possibilidades de existência do próprio espetáculo. Assim, o fluxo da narrativa tradicional sai de cena para dar lugar a uma estrutura de caráter episódico (como, por exemplo, num sonho). Decorre que a aparência geral de "naturalidade" do espetáculo desanda; por esta via, as marcas de sua execução não podem senão se darem a ver, fazendo-se presentes ao apontarem para si através dos saltos e improvisos que the são constitutivos. O que parecia "bem feito" num outro tipo de fazer artístico toma aqui um aspecto rudimentar de "bricolagem", já que o espetáculo acaba por explicitar os procedimentos materialmente necessários para criar cada uma de suas células constitutivas, ou seja, cada unidade ou quadro e, no conjunto, o mosaico que compõe o todo deste organismo vivo. Entornada a pseudonaturalidade, estranha a esta nova constituição, explicitam-se, imperiosamente, pelos procedimentos da superposição e da montagem, os elementos materiais que apontam para as marcas do trabalho realizado. E tudo aqui contribui para iluminar não apenas a obra em si mas também a estrutura ou armação que a emoldura: 1. a modificação ou modulação por parte do artista de seu número segundo as reações imprevisíveis de uma platéia ativa, regulando assim o ritmo da apresentação, ou seja, a ausência de ações padronizadas por parte do artista-trabalhador ao mesmo tempo que recebe e reage a impulsos externos, os estímulos físicos do público, 2. a síntese visual e gestual que disso decorre, oriunda da mímica e da pantomima, 3. o aspecto satírico, empréstimo direto da linguagem da caricatura, que esta síntese visual pode adquirir, 4. a fisicalidade das ações apresentadas no palco e a destreza e controle técnicos necessários para bem executá-la, requisitos fundamentais que, se ausentes, podem comprometer o artista a ponto de causar-lhe danos físicos graves o suficiente para afastá-lo de seu ganha-pão, 5. a mescla de gêneros considerados distintos ou díspares, presentes no mesmo número ou espetáculo, e 6. o tratamento de temas do cotidiano daquelas pessoas, artistas e espectadores, numa abordagem em sintonia com seus assuntos ${ }^{26}$.

${ }^{26}$ Para detalhamento do universo e procedimentos característicos do teatro de variedades ver 
O conteúdo desta matéria consiste primordialmente na descrição da vida da classe trabalhadora num ambiente geográfico e material ancorado no trabalho, nos esforços físicos e na improvisação. Tudo nesta atmosfera a isto se sujeita e disto decorre. Tomemos a precariedade das acomodações das classes trabalhadoras, que a qualquer momento dependeriam de planos emergenciais concebidos às pressas, frequentemente de forma coletiva, para continuarem de pé (a julgar pelas imagens da época, não era fácil distinguir, como vimos, entre um tenement novo e outro em ruínas) ou o espaço interno das casas, exíguo e inóspito, que impele os moradores e suas atividades para o exterior. Das formas de organização e improvisação de cunho coletivo e da "expulsão" dos moradores de suas casas para a cena da rua decorre o caráter frágil que assume qualquer distinção entre o público e o privado. Até mesmo um local que sem sombra de dúvida seria considerado "interior" ou "privado" em outro contexto, por exemplo, uma sacada, janela, escada ou telhado, torna-se aqui uma arena na qual se desenrola um "número" para uma platéia de espectadores interessados e curiosos, ou, inversamente, um camarote a partir do qual se assiste a outros "quadros" que se desenvolvem em outros espaços semelhantes, incluindo as vias públicas. Nesta espécie de teatro urbano feito pelo e para 0 pobre, como definir de maneira categórica as fronteiras entre interior e exterior, público e privado, palco e platéia, se a sala de estar passara à rua e vice versa? A porosidade advinda destes modos de organização social traz consigo um alargamento dos horizontes, criados a partir de novas constelações ${ }^{27}$, que incluem a possibilidade de modos inéditos de concepção, representação (e reversão?) de determinadas experiências societárias. A interpenetração de dados ou ações que já não se encaixam em suas definições correntes associada à existência dinâmica e coletiva de uma comunidade, que por outras vias não teria alternativa senão seu próprio esmorecimento, bane o selo do "definitivo" para, em seu lugar, instaurar uma ordem estribada no "contingente". Este

JENKINS, H. What Made Pistachio Nuts? - Early Sound Comedy and the Vaudeville Aesthetic. Nova York: Columbia University Press, 1992.

27 Cf. BENJAMIN, W. e LACIS, A. Naples. In BULLOCK, M. e JENNINGS, M. (ed.). Walter Benjamin - Selected Writings Volume 1 - 1913 - 1926. Cambridge, Massachusetts: The Belknap Press of Harvard University Press, 1996. 
cenário simplesmente não contempla o hirto ou a estagnação. A série de números variados neste teatro vivo denuncia que aqui nada "é": o que aparecia como estado imutável revela-se processo, portanto passível de reversão.

Trata-se, em suma, de uma matéria social que não é informe, um "teatro de situações" que refuta toda metafísica, transpira materialidade e que a explicita a cada momento da "encenação". Sem espaço para devaneios e quimeras, a "tigrada" da indústria cultural representa para si e seus pares, na vida e no palco, uma peça cujo didatismo nomeia, ainda que em diagonal, as vicissitudes e condições materiais de sua própria existência, em forma e conteúdo. Não abisma a identificação imediata da platéia.

Um dos quadros mais populares no teatro de variedades, modelar da experiência expressa no e pelo ponto de vista do subalterno, era um show de calouros intitulado "amateur night". Os prêmios chegavam a cinco dólares em ouro ou um relógio para o primeiro colocado e todos os candidatos ganhavam um dólar apenas por sua participação, o que naturalmente atraia um série de aspirantes a vencedores, pobres-diabos cujos "talentos" raramente se encaixavam na definição corrente do termo. Dado o caráter "heterogêneo" das habilidades demonstradas no palco, as apresentações poderiam ser dolorosamente tediosas para aquelas platéias cujas exigências já eram em parte pautadas pelos critérios da indústria, comprometendo, segundo elas, o "ritmo" do espetáculo. O público, sem o decoro observado nas casas de espetáculos grãfinas, logo se manifestava negativamente - na melhor das hipóteses com vaias e gritos, na pior, com uma dose considerável de brutalidade para com o candidato. De fato, o espetáculo era articulado como um jogo de espelhos, no qual aqueles que o frequentavam ora desempenhavam o papel do concorrente a prêmios e ora o faziam como integrantes de um júri popular que senhoreava sobre a população diante de si, reconhecendo o "mérito" de alguns e tripudiando sobre a massa dos incapazes de "fazer bem feito", escarnecendo-a. No limite, sujeitos e objetos confundiam-se no mesmo processo. 
Os administradores e organizadores do espetáculo, zelosos do sucesso porque atentos aos cifrões, logo perceberam que se tratava menos da valorização de reais "talentos" amadores desconhecidos, ou seja, do ato bem acabado que pretendia convencer a platéia de possíveis capacidades ou competências em geral imitativas, do que do sucesso do desempenho mambembe de números medíocres. Para a público, que atingia o delírio com os mais incapazes, valia a lei do "quanto pior, melhor". Uma espécie de gancho gigante foi logo introduzido ao show, instrumento com o qual o candidato indesejável era literalmente fisgado para fora do palco por um funcionário que atendia os desígnios perversos de espectadores siderados de estesia macabra, que entre risos sardônicos gritavam "Give 'im the hook", mescla entre "Fisgue-o!" e "Para fora com ele!". Não tardaria até que o gancho fosse alçado à categoria de astro principal do espetáculo. A nova vedete, expressão material da fereza generalizada, exigia um contingente sem fim de desafortunados, atores coadjuvantes a ela subordinados, ideais para o papel de si mesmos. Naquele que seria um dos quadros mais difundidos entre os teatros do gênero, davam a ver, pela via da fraude, do humor negro e da zombaria, que o conteúdo dos números era sempre o mesmo, um instantâneo fotográfico de sua própria experiência cotidiana, aquela da competição desigual, da humilhação contínua e da exclusão por mãos espectrais que nem ao menos conseguiam nomear. A burla era séria.

Weegee adorava o teatro de variedades e o contato que teve com este tipo de arte foi fundamental para o desenvolvimento de sua produção fotográfica. Frequentava o meio antes mesmo de tornar-se um de seus trabalhadores - "o teatro de variedades sempre me fascinou. [...] Miner's na Bowery, isto sim é que é viver!"28, diria mais tarde - mas como vendedor de doces em um dos teatros da Segunda Avenida, teve a oportunidade de assistir aos espetáculos gratuitamente, conhecer seus bastidores e frequentar os mesmos lugares de

${ }^{28}$ Cf. FELLIG, A. op. cit. p. 16. 
seus artistas e público, conhecendo a fundo a atmosfera ali reinante e dela se impregnando.

Vários dos procedimentos que ele próprio utilizaria como músico de cinema encontravam-se presentes também no vaudeville: a tentativa de ruptura da linearidade narrativa, a mescla de gêneros "distintos" e a improvisação e condução das atividades artísticas segundo o comportamento da platéia eram apenas alguns deles. Aprendeu também certos "números", que como fotógrafo encenaria sem pudores sempre que as situações exigissem, para, através dos quais, obter acesso privilegiado a um determinado evento ou situação, inatingível por outras vias. Eram famosos os disfarces que utilizava em mise-enscènes por ele concebidas, sketches armados para se fazer notar ou passar desapercebido, conforme sua conveniência, e assim fotografar o objeto como acreditava que deveria ser representado, produzir a imagem o mais rápido possível e comercializá-la antes da concorrência. Mas de forma alguma tais procedimentos se restringem em sua obra a meros adereços, truques que ao fim e ao cabo não revertem numa mudança qualitativa de sua imagística (e que só fariam reiterar a imagem distorcida de um Weegee bufão e inconsequente).

Relevante mesmo para sua prática fotográfica é a somatória e a incorporação formal das experiências vividas no universo do trabalho no cinema e no teatro de variedades, de semelhante intensidade, ordem e grandeza, à fatura de suas imagens, nas quais o fotógrafo codificará, como veremos adiante, uma ótica radicalmente distinta daquela até então utilizada na e pela fotografia norteamericana, e não apenas aquela do período. O caráter díspar de suas imagens consistirá precisamente na elaboração e explicitação formal de um ponto de vista que não somente informará o local social do narrador mas sua posição nas relações de produção. De que modo? Grande parte do aparato cultural moderno, a indústria da notícia e do entretenimento nas grandes metrópoles para quem Weegee e seus semelhantes trabalharão, é resultado e produto da apropriação e desenvolvimento de modos populares de expressão e diversão, como o teatro 
de variedades, os bailes e boates populares, os parques de diversão (como Coney Island, posteriormente fotografado por Weegee), os esportes (como o baseball) e as chamadas "penny arcades", locais nos quais a diversão era tentar ganhar algum trocado fazendo apostas em máquinas caça níqueis ${ }^{29}$. Num futuro muito próximo, o processo de desenvolvimento desta mesma indústria suprimiria, como vimos no caso do cinema silencioso, a necessidade de contratação de mão de obra especializada para as apresentações ao vivo. A massa destes trabalhadores, deslocada para um novo contexto de trabalho, agora no seio da produção cultural industrial, reprodutível e serializada, imprime, aos poucos, seu "sotaque plebeu" característico tanto às formas de trabalho como às mercadorias postas à venda pela indústria do consumo de cultura de massa. Isto porque se por um lado as novas configurações do moderno aparato cultural criava e ampliava uma massa de consumidores passivos cuja percepção estética era estruturalmente degradada pelo consumo de mercadorias que não passavam de fantasias escapistas (a tese de Adorno e Horkheimer), por outro esta mesma indústria recrutava e aglutina um sem número de trabalhadores que contava com a possibilidade e a vivência de organização social e política suficientemente fortes para permitir a criação de formas artísticas que dialogassem com a realidade que viviam que, por sua vez, não era, como vimos, informe. No limite, estes novos operários da cultura, e Weegee é um de seus representantes, diminuiriam a distância entre o trabalho manual e o trabalho intelectual. Em Naked City a narrativa será assim urdida, tecida neste comprimento de onda, produto da operação de adição do ponto de vista do trabalhador ao do excluído. Toda e qualquer escolha feita pelo fotógrafo será orientada e justificada neste termos: o recorte no conteúdo, a temática escolhida, a seleção e organização dos materiais, a abordagem proposta e o público ao qual o material se destina. Ao fabricar este ponto de vista e torná-lo eloquente em seu primeiro livro, Weegee iça a fotografia, a literatura e a combinação de ambas a um patamar inédito, pois é somente por ele e a partir dele que poderá pôr em xeque os modos tradicionais de documentação da vida

${ }^{29}$ Cf. DENNING, M. op. cit. 
urbana, aniquilando a distinção (até hoje corrente) entre fotografia documental e fotografia artística e desmantelando com ela as fronteiras entre arte popular e arte culta.

No início do século XX a única ferramenta e termo de aferição da importância, prestígio e valor artístico - e venal - de qualquer produção fotográfica era um metro intitulado pictorialismo. Quanto mais próximo das regras prescritas pelo movimento artístico-fotográfico, que nos Estados Unidos fora organizado em torno de Alfred Stieglitz e seu círculo, maior a grandeza da obra, que por estas vias lutava arduamente para ser aceita no círculo "sério" das belas artes. Neste cenário, pode-se imaginar o local destinado aos retratistas ambulantes ${ }^{30}$. Párias no último estágio da hierarquia da indústria fotográfica, eram os intocáveis que os aspirantes a artistas de prestígio repudiavam com intensidade inversamente proporcional ao valor que atribuíam aos axiomas preceituados pela Academia. A precariedade das condições dos "Weegees" sequer permitia que tomassem conhecimento destas forças vetoriais, de tal movimento artístico ou do ódio que nutria por tudo que remotamente ousasse deslocar a fotografia das paredes das galerias de arte para os muros das ruas. Sem ciência ou opção, era ali que o garoto iniciaria seu contato com a profissão, descobrindo um nível ainda menos elevado no ranking artístico: aprendiz e assistente de fotógrafo ambulante.

Entre 1913 e 1916, já fora da casa de seus pais, conhece um fotógrafo ambulante para quem trabalha durante algum tempo aprendendo o ofício. Conhecidos como tintype photographers, eles produziam essencialmente retratos de transeuntes utilizando a técnica do ferrótipo. Esta consistia essencialmente na umidificação de uma plaqueta de ferro (daí a associação com

30 Vale notar a enorme semelhança entre o futuro trabalho de Weegee e o local ocupado pelos retratistas ambulantes e seu desempenho como fotógrafos e cinegrafistas retratados no filme $O$ homem das novidades (The Cameraman, de 1928), de Buster Keaton. 
a palavra inglesa "tin", que significa lata ou latão) com colódio, um composto de éter e álcool em partes iguais numa solução de nitrato de celulose, substância que possibilitava a aderência do nitrato de prata foto-sensível ao suporte utilizado. A técnica era popular entre os profissionais do ramo em virtude da rapidez de sua produção, seu baixo custo e, principalmente, por não oferecer riscos de quebra ou danos evidentes ao produto final entregue ao cliente (ao contrário do que acontecia com os negativos de vidro). Como principiante, Weegee era responsável por auxiliar o mestre no processo de revelação das imagens, entregá-las aos clientes e cuidar do pônei do fotógrafo, misto de estrela e chamariz que ajudava a conquistar a simpatia e os trocados dos pais das crianças mais insistentes. O emprego Ihe rendia muito pouco mas oferecia atraentes benefícios que se somavam a seus ganhos: não precisava mais se preocupar em buscar abrigo noturno, pois o fotógrafo permitia que dormisse no estábulo com o pônei.

O garoto tinha tino comercial e aprendeu rápido os traquejos da profissão, que de fato não encerrava maiores segredos. Almejando ganhos mais significativos e um pouco mais de conforto material decidiu tentar a sorte autopromovendo-se à condição de fotógrafo ambulante, não sem antes sondar o mercado das redondezas do Lower East Side, aquele que melhor conhecia, uma região que se provara potencialmente lucrativa, ao menos para o início de sua carreira solo ${ }^{31}$. Verificou, a partir da própria experiência doméstica, que as famílias de imigrantes tinham por hábito guardar com particular afeto as fotografias de seus entes queridos. Também percebeu que tais famílias, por mais empobrecidas que fossem, não costumavam poupar esforços ou dinheiro para fazer um retrato dos menores. "As pessoas amavam suas crianças e não importava quão pobres elas

31 Lembremo-nos que até então o garoto trabalhava simultaneamente numa série de empregos e a fotografia era apenas mais um deles. É impossível determinar a sequência exata de todas as suas atividades. No entanto, sabemos que nesta época já havia trabalhado como vendedor ambulante e tido contato com o teatro de variedades. Seu emprego como violinista em cinemas viria um pouco mais tarde. Somente deixará seus múltiplos trabalhos, cada qual com diversas tarefas, quando se tornar foto-jornalista profissional. Cf. FELLIG, A. op. cit. 
fossem, acabavam sempre por arranjar a grana para as minhas fotos"32, lembra Weegee. Munido da câmera fotográfica comprada de segunda-mão e do pônei que alugara para si, apelidado de "Hypo"33, saiu a campo.

Os dias de trabalho mais rentáveis eram aqueles do fim de semana, momento em que boa parte das crianças vestia suas melhores roupas para brincar nas ruas do bairro. Weegee as fotografava, não raro sem mesmo o conhecimento de seus pais, após um ritual que concebeu (a partir de seu treinamento inicial) para cativar a clientela: limpava e alinhava o freguês tanto quanto possível, apresentava-Ihe o animal e fazia com que se aproximasse dele. Persuadi-lo a dar uma volta pela rua no lombo de Hypo não demandava esforço; a técnica contribuía não apenas para convencer o "felizardo" a tirar seu retrato mas expunha e anunciava o serviço oferecido pelas redondezas. Tendo anotado 0 nome e endereço dos fotografados, levava nos dias que se seguiam as provas iniciais das imagens às casas dos adultos responsáveis, que invariavelmente encomendavam cópias definitivas pagando vinte e cinco centavos de dólar por uma fotografia ou, na promoção, três por cinquenta. As cópias eram feitas ali mesmo, na própria cozinha do cliente, misto de laboratório momentaneamente improvisado, recepção de atelier fotográfico, gabinete de curiosidades, palco e platéia ${ }^{34}$, um cenário ajambrado primordialmente para demonstrar e evidenciar, ou ainda, para encenar o trabalho executado. Dependendo de sua habilidade

\footnotetext{
32 Cf. FELLIG, A. op. cit. p. 18.

${ }^{33}$ A esta altura, Weegee já deveria possuir um bom domínio da técnica fotográfica. Sabia o papel que cada componente químico desempenhava no processo de captura, revelação e ampliação das imagens que produzia, dando indícios concretos do humor e do caráter investigativo de suas futuras imagens. Em inglês, hypo significa, no campo da fotografia, hiposulfito, um material químico utilizado para a fixação das imagens fotográficas no papel ou suporte desejado, após as etapas de ampliação e revelação. Também se refere à abreviatura da palavra hipopótamo, o que provavelmente seria um atrativo extra para as crianças que seriam fotografadas no animal, em teoria de proporções "semelhantes" (importante notar que esta técnica foi também derivada do aprendizado adquirido com o profissional que lhe ensinara o ofício). Por fim, o termo também pode se referir à forma abreviada de hipodérmico, ou seja, aquilo que se encontra por debaixo da pele (ou, no caso de Weegee, da superfície aparente ou visível dos fenômenos investigados). Como pretendo argumentar adiante, Weegee encaminhará sua prática cada vez mais no sentido da última definição conforme se desenvolviam suas atividades no meio fotográfico.

34 "O cômodo logo ficava repleto de vizinhos e parentes, que sentados em caixas de sabão olhavam as provas iniciais." Cf. FELLIG, A. op. cit. p. 18.
} 
técnica, o artista mambembe conquistaria também a simpatia e os cobres do restante do público, os parentes ou vizinhos curiosos que normalmente se apinhavam na "galeria" para assistir à "encenação".

Mas o que esperava esta platéia de Weegee? Como triunfar perante seu público, ser agraciado com o prêmio máximo e voltar na semana seguinte com chances redobradas de vitória? No caso do jovem fotógrafo, a resposta era inequívoca: o ápice de seu número, a saber, o fruto de seu trabalho, deveria ser a produção de imagens que seguissem à risca as demandas da freguesia. E a clientela de imigrantes pobres decretara que suas crianças deveriam aparecer brancas nas imagens. Nada de aproximações delicadas ou sutileza de tons; queriam todos brancos, pseudo-caucasianos, espectrais ${ }^{35}$, ainda que isso significasse a mais brutal ruptura com qualquer possível vestígio de "realidade" da imagem fotográfica. O garoto, uma dessas crianças, não carecia de maiores explicações quanto às dificuldades que encontrava a população imigrante de assimilação à cultura e sociedade locais. Racismo e preconceito não the passaram desapercebidos. Como objeto e sujeito de suas próprias fotografias, compreendia que a platéia exigia presente nas imagens o retrato fiel da percepção que tinha da realidade e possivelmente também tudo o que sabia dela se ausentar. Weegee conhecia as consequências do malogro e não estava em posição de sugerir padrões estéticos. Tornando expressivo seu ponto de vista, satisfaria as expectativas do público forjando uma forma artística em consonância com uma determinada forma social.

Concebeu assim um método quase infalível (que desenvolveria à perfeição no decorrer de sua prática fotográfica) de fazer com que crianças de praticamente qualquer cor aparecessem esbranquiçadas nas fotografias em preto e branco: ampliava as imagens em papéis de alto-contraste, o que significava, na maioria dos casos, a presença de brancos alvos e negros intensos, com a quase completa ausência de meios-tons (as correspondentes variações de cinzas)

35 "Chalky" ou "dead-white", nas palavras de Weegee. Cf. FELLIG, A. op. cit. p. 18. 
entre um e outro. A profundidade de campo era praticamente reduzida a zero; não criava, portanto, distância, mas, ao contrário, aproximava elementos e adensava suas relações. Visualmente, o espectador se confrontava com um produto final bastante "grosseiro": uma superfície bi-dimensional que servia de tablado para o combate explícito entre cores, brancos e pretos profundos que não mais se apresentam como tom cromático local mas como substância do espaço pictórico, e formas, corpos com volumes matéricos espessos como reboque construídos a partir desta concepção cromática. Nesta arena, uns investiam contra os outros, atracando-se entre si e intensificando em termos visuais a encenação de um conflito irreconciliável, travado entre elementos diametralmente opostos. Aqui, até mesmo a luz é matéria, vibração maciça num espaço que não é construção perspéctica concebida a priori mas algoritmo da consciência fenomênica. Neste universo, o fotógrafo varre todo resquício de expressão psicológica ou traço de particularidade característico. Cada criança, oca de si, ganha um quantum significativo de universalidade. Despejada a subjetividade da qual jamais gozara, extrai do fotografado sua essência ao reduzi-lo ao típico. Cada criança torna-se, então, um fragmento que contém em si seu todo: personagem sem persona, é um e todos, crianças e adultos ${ }^{36}$. A grosseria das imagens equivalia à marginalização que sofriam pela sociedade bem educada e à brutalidade generalizada da vida. Mas qualquer artistafotógrafo concordaria que tratava-se de depreciação da Arte: Weegee fazia uma "fotografia suja".

Para aqueles educadores do gosto, a produção artística pictorialista buscava refletir a idéia de qualidade, ordem, proporção, ritmo, equilíbrio e harmonia, em suma, a busca de experiências estéticas da ordem do belo metafísico pelas alamedas de um classicismo empedernido, apanágio das academias e salões de belas artes, aos quais, como vimos, esta fotografia sequer estava plenamente integrada. Como mordomos das artes superiores, insistiam na representação da

\footnotetext{
${ }^{36}$ Tais fotografias encontram eco em Naked City na imagem da criança indigente fotografada no capítulo 16: "Odds and Ends" (as "sobras" ou "rebotalho"). O poodle bem tratado da Park Avenue na página da esquerda é seu par na montagem proposta pelo autor.
} 
beleza do mundo visível, o que significava essencialmente duas posições distintas com idêntica abordagem: ou voltar-se ao universo bucólico da natureza, representando-o a partir dos códigos e regras concebidos e consagrados (Poussin, Claude Lorrain) ou embelezar artificialmente as grandes metrópoles, nos mesmos termos nostálgicos e estetizados (Stieglitz). Nenhuma destas posturas poderia prescindir da estilização estática e cerimonial que mascarava o caos da vida urbana, em imagens concebidas sobretudo para o aquecimento do mercado das artes fotográficas. É certo que o movimento pictorialista já se encontrava enfraquecido e em breve veria seu próprio fim. Mas muitas de suas concepções fundantes encontrariam ecos nas mais diversas variações ou expressões estéticas que se seguiriam - uma das mais difundidas seria a concepção divinizante da arte. Ao afastar-se de toda prática normatizada, aproximando-se da linguagem cotidiana (aquela do jornal, e mais especificamente a do tablóide), Weegee explicitará a deficiência do modelo petrificado, desferindo contra ele os mais violentos golpes. Neste sentido, retratará o ambiente urbano de modo a representar seu objeto como ao mesmo tempo uma vítima da cidade e o agente de sua possível transformação, introduzindo-o formalmente no campo visual pela via do alto contraste exacerbado, efeito de estranhamento que desmantela as leis "naturais" da indexação ${ }^{37}$ da imagem fotográfica.

Mas a revolta de Weegee não era contra o gosto acadêmico que desconhecia ou a liberdade de fruição artística isenta de preconceitos estéticos atrelados a formas nostálgicas passadas. Impõe-se para ele a necessidade de um novo classicismo, não mais calcado na imitação livresca dos antigos, mas dedicado a forjar uma imagem realmente original e concreta do mundo material do qual faz parte o coletivo ao qual pertence, imagem esta que não deveria ser buscada na cópia visível das aparências da realidade exterior, mas na consciência (um "estar no mundo") de seu produtor. Esta operação artística, que propõe a

${ }^{37}$ Ao fazer uso do termo "indexação", acentuo minha distância das abordagens críticas como a semiótica, que aqui certamente preferiria o uso do termo corrente em seu vocabulário teóricocrítico, "indexicalidade". 
compreensão de processos, não reproduz o mundo; produz a sensação de nele estar, mantendo-a viva, e não como dado para reflexão a posteriori mas como consciência em ação. Não opera por silogismos mas efetua-se concomitante à experiência viva e atual da realidade. Ao iniciar o processo que eleva a sensação visual ao nível da consciência, Weegee amplia, ainda de modo incipiente ou claudicante, o horizonte de seus experimentos artísticos, filiando-se à produção de vanguarda que será característica da Frente Cultural. Sem o saber, o jovem trabalhador inicia o percurso que aos artistas-fotógrafos da época jamais ocorreria: refazer Poussin, reencontrando "a história na natureza, a experiência refletida do passado no flagrante da sensação"38.

Sem o conhecimento de suas conquistas imediatas, que seriam desenvolvidas e ampliadas durante sua prática profissional, o aprendiz de fotógrafo retoma alguns séculos da história da arte que o precedia. A partir dos ensinamentos de mestres que jamais conhecera, num arco que se estende do velho Bruegel a Manet e Cézanne, avança em relação às produções artísticas mais consequentes de sua hora histórica graças ao desenvolvimento e aos usos dos meios e técnicas reprodutíveis, utilizados aqui a serviço do proletariado no campo das lutas de classes. A melodia que entoara $O$ velho músico de Manet (1862) encontra eco no jovem violinista e chega vivificada ao fotógrafo. A partir dos imperativos do mundo do trabalho e da experiência do oprimido, democratiza-se seu fazer e sua expressão; agora é o refrão de um coro. Toda ferramenta que pretendia criar obras primas monumentais fora substituída pela câmera fotográfica que torna eloquente o desiderato da massa silenciosa. E ela determina expressamente que a sua verdade cotidiana seja descrita. Pelas imagens produzidas por esta câmera escutam-se seus urros. Pelo trabalho deste petit métier exigem, como outrora fizeram com Atget, a sua parcela do "lado belo da vida". Ao sussurro do mestre francês corresponde o brado do imigrante. Estabelecendo o choque como o princípio formal constitutivo de sua

${ }^{38}$ Cf. ARGAN, G. C. Arte moderna - do iluminismo aos movimentos contemporâneos. op. cit. p. 113. 
obra fotográfica, corolário de um modernismo que não pode ser visto apenas como experimento formal nem como conjunto de pressupostos de caráter meramente estético mas sobretudo como um projeto político coletivo, Weegee re-atualiza as bases fotográficas para um novo Realismo no epicentro da Meca que forjara e consolidara o mito do progresso nas bases do pragmatismo industrial capitalista. O olhar plebeu de Weegee areja a fotografia. Se ele a conspurca, as nódoas são de pura vida. O habitat natural do garoto era a sarjeta e é para lá que ele arrasta a fotografia, elevando-a a este nível. Erigiu com os seus, tijolo por tijolo, a dissonância como indicador de uma nova harmonia.

A constelação histórica que permite o florescimento de um Weegee não exclui, como sugeri, o movimento de expansão e modernização da indústria da notícia, que a partir do final do primeiro decênio do século XX apostava todas as suas fichas no que posteriormente se denominaria "imprensa ilustrada". "llustração" significava desenhos e quadrinhos mas sobretudo o vasto uso de fotografias que acompanhavam as matérias publicadas. Utilizadas desde 1873, a novidade não era propriamente o emprego da fotografia em si, mas a quantidade de imagens presentes em praticamente todos os jornais que circulavam no país. Em 1919 o tablóide de Nova York Daily News inicia um movimento que inquieta os concorrentes: intensifica o emprego de material fotográfico, experimentando usos distintos para as imagens, que incluíam a publicação de fotografias de dimensões variadas agrupadas na mesma página, a veiculação de imagens de caráter sensacionalista e a diagramação visual inusitada ou pouco ortodoxa. A concorrência não poderia ignorar as modificações, que logo se tornariam tendência. No final dos anos vinte os tablóides da cidade, com circulação superior a um milhão de cópias diárias, já haviam re-definido o sentido da palavra "notícia", que incorporara fortemente o conceito de "informação fotográfica". O lançamento da revista Life em 1936, "an all photography news 
magazine" (uma revista informativa de cunho essencialmente fotográfico) como se auto-denominava, só faria consolidar a ideia - e evidentemente o mercado que se abria para uma vasta gama de trabalhadores, dentre os quais artistas, desenhistas, caricaturistas, laboratoristas, jornalistas, técnicos variados e fotógrafos ${ }^{39}$. Como muitos, Weegee não desprezaria tal oportunidade. Sua experiência profissional se consolidaria nestes anos formativos da imprensa ilustrada e do foto-jornalismo.

Cansado de fazer o retrato de turistas num estúdio fotográfico especializado em fotografias para passaporte, o jovem de vinte e quatro anos decide trabalhar em uma agência de notícias instalada na cidade, Acme Pictures, formada com o intuito de prover imagens para os jornais da rede do magnata da imprensa Edward Scripps. As maiores e mais poderosas agências norte-americanas, Associated Press Photos e Wide World Photos, exigiam contratos de exclusividade, formavam um cartel, definiam os valores a ser praticados e ditavam as regras sobre a natureza das imagens comercializadas, que não forneciam à concorrência. A outra grande agência, International News Photos, era especializada em imagens de artistas de Hollywood em poses inusitadas (a chamada candid photography). Scripps, que não pretendia se submeter aos ditames dos concorrentes, criara a Acme e pretendia trazer inovação ao setor.

\footnotetext{
39 O império erigido pelo magnata norte-americano da indústria da notícia Henry Luce permitiu, ainda que por pouco tempo e a despeito de suas posições políticas abertamente reacionárias, a contratação de mão de obra composta por artistas, escritores, fotógrafos e outros profissionais ligados ao ramo jornalístico simpatizantes ou engajados na política da Frente Popular. Seriam estes os profissionais que alargariam as fronteiras técnicas e estéticas na/para a produção de notícias em veículos como jornais, revistas, programas de rádio e cine jornais, imprimindo seu característico "sotaque plebeu" à tais produções (incluindo até mesmo as mais conservadoras como Fortune). Diversas revistas ligadas à Frente Popular como Direction (uma revista de artes), Ken (uma publicação política bi-semanal) e Friday (uma revista de variedades concebida nos moldes da francesa Vendredi, sua correspondente no Front Populaire) se espelhavam na Life de Luce. Orson Welles, além de vários dos atores que compunham sua trupe, o Mercury Theatrer, trabalhariam como atores anônimos no famoso March of Time, o newsreel de Luce, recriando eventos contemporâneos para transmissão radiofônica (vale lembrar que o título do cine-jornal escolhido pelo Welles de Cidadão Kane é News on the March, evidente indicação tanto da fonte de inspiração como das semelhanças estruturais entre Hearst e Luce). Como pretendo demonstrar adiante, o tablóide nova-iorquino PM Daily bem como a vivência profissional de Weegee neste jornal são signatários da experiência acima descrita. Para detalhamento da trajetória e influência de Henry Luce na Frente Cultural, ver DENNING, M. op. cit.
} 
Em sua filial nova-iorquina, Weegee começaria como assistente de laboratorista - e ainda era "Arthur".

A tarefa de revelar os filmes e ampliar as fotografias ficava a cargo dos profissionais responsáveis e mais experientes. O processo compreendia as etapas de revelação, interrupção da revelação, fixação, lavagem e secagem, tanto para o filme fotográfico como para a imagem, imediatamente após sua ampliação. A obrigação inicial de Arthur, ocupação mais próxima ao rés-do-chão num laboratório fotográfico, era a de remover o excesso de água das imagens que já haviam sido lavadas antes da secagem final, utilizando como ferramenta de trabalho um pequeno rodo, em inglês, "squeegee". Como tinha a intenção de permanecer no emprego e entendia o que isto significava, executava o serviço com a máxima perfeição e rapidez. Em breve era o mais capaz dos ajudantes e os laboratoristas disputavam sua ajuda. Toda vez que uma imagem estava pronta para ser secada, gritavam: "Squeegee!". E queriam apenas o auxílio de "Mr. Squeegee", como Arthur acabou conhecido no laboratório. Para seu azar, as moças do local o achavam muito feio e frequentemente o comparavam às figuras diabólicas que ilustravam os tabuleiros de ouija ${ }^{40}$, a febre do momento na cidade (o garoto de fato não correspondia a qualquer quesito ditado pelo padrão de beleza norte-americano da época; ele não era nenhum galã de cinema). A palavra "ouija" tem, em inglês, pronúncia semelhante a "squeegee". Arthur logo associou elementos que pareciam distintos: ao "Rodinho", oriundo do mundo do trabalho, somaram-se as qualidades fenomenais ou "para-normais" provenientes do mundo do entretenimento, desenvolvidas para sobreviver na função. O apelido the servia inclusive como ferramenta de promoção; a grafia do

\footnotetext{
40 Trata-se de um quadro feito de plástico ou madeira no qual se encontram todas as letras do alfabeto, os números de zero a nove e algumas respostas básicas como "sim" e "não". Ele é usado num misto de jogo, brincadeira e sessão de ocultismo em que espíritos, após evocados pelos participantes, supostamente respondem suas perguntas fazendo mover um ponteiro ou copo, que apontará ou formará a resposta. O tabuleiro já era amplamente comercializado nos Estados Unidos pelo menos desde 1800, sendo oficialmente patenteado em 1890 e comercializado sob o nome de "Ouija" a partir de 1901, alcançando repetidos recordes de vendas até meados dos anos sessenta.
} 
"neologismo" ficara por sua conta ${ }^{41}$ (assim como a pronúncia que ele utilizava; no sotaque típico do Lower East Side de Manhattan, "Weechee"/tch/). Quanto a seu "significado", transmutaria com o passar da prática profissional do dono.

O fato é que na agência teve seu primeiro contato com o mundo da fotografia como negócio organizado e lucrativo, inserida no âmbito da indústria da notícia, e mais especificamente da notícia direcionada à publicação em jornais da cidade, não raro, tablóides. Em seu quadro fixo de funcionários a agência contava com editores de fotografia, fotógrafos, técnicos de laboratório, técnicos especializados em retocar negativos e fotografias (limpando impurezas sedimentadas no processo de revelação ou ampliação ou simplesmente removendo quaisquer elementos indesejáveis da imagem), escritores cuja tarefa era dar títulos às fotografias produzidas e auxiliares diversos. Como trabalhador não-especializado no último estágio de um processo análogo à produção industrial, Weegee já percebera, como vimos, a fragilidade da posição que ocupava e faria o possível para ascender a níveis mais "confortáveis". Nesta "linha de montagem", teria em breve sua chance como laboratorista responsável pela ampliação de fotografias.

No laboratório provou-se um ás. Aperfeiçoou a técnica que já conhecia, ampliando imagens com exímia maestria e qualidade mesmo a partir dos negativos mais inadequados. Não era apenas o melhor, mas também o mais rápido, quesito fundamental para obter sucesso na posição: ampliava cerca de mil imagens diariamente, um feito inigualável no ambiente de trabalho. Com status semelhante aos trabalhadores mais experientes, adquiriu o privilégio de circular por outros departamentos da agência, expandindo seu conhecimento sobre o processo de produção como um todo. Aprendeu como os editores selecionavam as melhores imagens para publicação e como tais imagens poderiam ser utilizadas em artigos que captassem o interesse dos leitores, como os técnicos retocavam os negativos e as fotografias, como os escritores

${ }^{41}$ Cf. BARTH, M. Weegee's World. Nova York: Bulfinch Press Book, 1997. 
intitulavam as imagens e, naturalmente, como os fotógrafos produziam suas fotografias. A essa altura, concluiu o que posteriormente the seria óbvio: as imagens poderiam e deveriam sofrer manipulação, tanto na revelação do filme quanto nas etapas do processo de ampliação fotográfico. Ou ainda, na própria concepção da imagem, antes mesmo de sua realização.

"Acme era um bom lugar para trabalhar. Aqui havia o tipo de fotografia que eu estava procurando. Nada de naturezasmortas de estúdio comercial, nada de retocar rugas e remover os pelos e os papos dos retratos de garotas, nada de fotografia de passaporte. Pela primeira vez na vida estava feliz. O cheiro dos químicos me excitava! Eu estava aprendendo fotografia. [...] Das bandejas do laboratório da Acme a história passava pelas minhas mãos: incêndios, explosões, acidentes de trem, colisões de navios, guerras de gangues, assassinatos, reis, presidentes, todos os famosos e tudo de mais estimulante que aconteceu nos anos vinte. Eu manuseei o primeiro flash em bulbo, produzido pela General Electric, que substituiu o perigoso flash em pó. Vi a primeira fotografia do presidente Coolidge transmitida por cabo telefônico da Casa Branca para Nova York. Fui eu quem a revelei. A fotografia estava crescendo e eu com ela." ${ }^{42}$

Se Weegee já era considerado o melhor laboratorista da Acme, não entendia porque não poderia vir a ser também o melhor fotógrafo. Queria produzir as imagens que ampliava e a essa altura acreditava que já havia aprendido o suficiente com os parceiros do trabalho para iniciar a empreitada. Afinal, grande parte do que percebia como a história cotidiana que passava por suas mãos, incêndios, explosões, acidentes e assassinatos, não the era estrangeira. Se a conhecia tão de perto na vida, por que não ele a transformá-la em imagem?

${ }^{42}$ Cf. FELLIG, A. op. cit. pp. $26-28$ (meus grifos). 
Afinal, não era ele uma testemunha ocular deste universo do fait-divers? Quem mais qualificado ao acesso às pessoas, locais e métodos para penetrar o submundo, escrutiná-lo e reapresentá-lo aos leitores ávidos pelo consumo de fatos e fotos sensacionalistas? Antes faltavam-lhe a técnica e os conhecimentos imprescindíveis para produzir e comercializar uma fotografia. Agora, de posse do aperfeiçoamento de que carecia, tornara-se um bom especialista e um excelente generalista. Nenhum de seus colegas de ofício reuniam os atributos necessários, em quantidade ou qualidade, para competir com Weegee em patamar de igualdade; ele reinaria supremo no bas-fonds de Nova York.

Em 1935 Weegee deixa a agência e inicia a carreira de fotógrafo freelance. Ao considerar suas possibilidades de atuação no mercado, percebeu que pouquíssimos jornais nova-iorquinos mantinham seus fotógrafos nos turnos da noite. Decide explorar este filão, cobrindo os incidentes noturnos. Seus contatos com membros do corpo de bombeiros mas sobretudo com a polícia permitiam que rondasse as delegacias em busca de informação confiável que o levasse a algum "furo". Gozava de tamanha consideração entre as autoridades que em 1938 recebeu um documento oficial emitido pela polícia, um distintivo policial que certificava sua condição de fotógrafo de imprensa, insígnia que lhe abriria ainda mais portas com muito mais facilidade. Mas para manter o emprego num ambiente ligado ao mundo da notícia e do jornal, no qual a instantaneidade e a transitoriedade da informação determinavam a velocidade com que 0 profissional deveria executar seu trabalho, somente o olho atento ao teletipo de uma delegacia policial e um passe de imprensa não seriam suficientes.

A produção serializada e padronizada das imagens que ilustram as matérias jornalísticas cotidianas nos termos do fait-divers exige do profissional extrema agilidade e destreza técnica. Como um caricaturista, ele deve rapidamente 
"esboçar" o fato na imagem que produz, sob pena de dar vida a um produto que se tardar a ser executado já nascerá obsoleto ou, para falar nos termos da indústria da notícia, será yesterday's news. E para não correr tal risco, o profissional deverá, imperiosamente, circular pela cidade, buscar o fato, documentá-lo, produzir a imagem, comercializá-la e, num círculo sem fim, reiniciar o processo. No caso de Weegee, isto significava que deveria representar diversos papéis simultâneos, que não eram necessariamente excludentes ou aconteciam sempre numa ordem pré-determinada. Atuava como um detetive (para descobrir o fato), fotógrafo (para capturá-lo), artista ambulante (por exemplo driblando os possíveis empecilhos ao ato de fotografar com suas "performances" ou, o que não era incomum, revelando os filmes nas condições mais adversas, enquanto se dirigia aos locais de outras ocorrências), técnico de laboratório (para revelar os filmes e ampliar as imagens) e ambulante astuto (para vendê-las pelo preço mais favorável). Tudo em tempo real, "on line".

Não poderíamos nos encontrar mais distantes do universo da obra de arte única, bem acabada e produzida artesanalmente, idealizada para a fruição individual ou para um culto qualquer. A fotografia é aqui concebida desde o início como uma imagem para a reprodução em larga escala, um produto destinado à publicação no mercado editorial, cujo suporte não será o nobre papel artístico (normalmente os papéis fotográficos de fibra, em cópias com tratamentos laboratoriais altamente sofisticados e dispendiosos), destinado à produção high art, mas o mais mundano deles todos, o papel jornal, áspero e tosco. Esta imagem é, enfim, o produto do trabalho e das capacidades que deve demonstrar um operário flexível e multifuncional, pautado pela produção de ritmo análogo àquele dos processos industriais, que rapidamente atinge também a indústria da notícia no intuito de modernizá-la ${ }^{43}$. Cabe a este chiffonnier hi-tech a tarefa de varrer o espaço urbano e coletar os fragmentos da vida na metrópole que por

${ }^{43}$ Woody Allen daria notícia deste processo em seu $A$ maldição do escorpião de jade (The curse of the jade scorpion), filme de 2001. 
suas mãos ou, se preferirmos, por suas lentes, estamparão as páginas dos jornais do dia seguinte; este era o business de Weegee.

E para melhor circular, o fotógrafo obteve a permissão inédita das autoridades policiais de instalar no veículo que conseguira comprar um rádio de ondas curtas que transmitia aos agentes de polícia informações e instruções quanto às ocorrências noturnas que deveriam cobrir. Weegee, que já morava num cômodo atrás de uma delegacia de polícia para facilitar sua vida de foto-jornalista, encontrava-se agora em plenas condições de circulação: não apenas possuía seu próprio veículo, um verdadeiro escritório fotográfico ambulante, mas obtinha, pelo rádio policial, informações precisas quanto à natureza das ocorrências policiais, locais dos acontecimentos e as melhores condições de acesso. Chegava com status de autoridade oficial e não era mais barrado pela polícia; executava o trabalho quase como um membro da corporação. Otimizava, assim, seu tempo ao máximo: 1. operava a seleção dos eventos que mais the interessavam cobrir, no geral os mais "sensacionais" porque os mais cotados no mercado para o qual se destinavam as imagens, 2. alcançava o destino com rapidez e, 3. sem grandes empecilhos, 4. produzia em primeira mão a imagem que 5. venderia em seguida ao primeiro jornal interessado. Chegava a cobrir com sucesso de quatro a seis eventos distintos por noite, o que para os outros foto-jornalistas sem semelhantes recursos era simplesmente impensável. Contava também com invejável vigor físico e mental para, noite após noite, enfrentar as situações mais extenuantes: toda sorte de incidentes com alto grau de violência, incluindo, na linguagem de humor negro da imprensa especializada, "roasts"44, "dry divers"45 e "bottom fenders"46. Logo espalharia 0 boato de que sua resistência, habilidade e competência advinham de seus poderes para-normais, permanentemente ligados a um outro mundo.

\footnotetext{
44 "Torrados" ou vítimas de incêndios.

45 "Mergulhadores a seco" ou suicidas que se atiram de altos edifícios.

46 "Guardas-fundo", suicidas ou vítimas de afogamento.
} 
É bem verdade que Weegee possuía uma sensibilidade singular, em sintonia fina com outro mundo. Mas as forças do "universo paralelo" às quais se referia e que alimentavam sua prática certamente incluíam aquelas produzidas no e pelo sub-mundo da cidade. Quando seu trabalho não podia ser executado pelos métodos mais ortodoxos, ou seja, toda vez que os procedimentos oficiais se provavam insuficientes, o que não era de todo raro - pensemos, por exemplo, numa noite particularmente calma, em que o teletipo ou o rádio tardassem a anunciar, se é que o fariam, um incidente ou desastre "sensacional", fonte primária de seu ganha-pão - contava com o auxílio da vasta rede de relações que cultivava no sub-mundo, trabalhadores que atuavam na vida noturna e nas ruas da cidade como empregados e donos de boates ou de restaurantes, porteiros, atendentes de bar, manobristas, ambulantes, motoristas e enfermeiros de ambulância, pedintes, além de toda sorte de marginais. Numa combinação vetorial de forças, era a eles que Weegee apelaria para recolher material, coletar dicas e reunir os dados que o levariam às imagens que produziria.

Esta rede paralela, organizada de modo distinto daquelas que se consolidavam na indústria da notícia, guardava formas residuais de trabalho distantes do fordismo que se instalara na indústria da notícia, privilegiando sobretudo maior cooperação entre os trabalhadores (que, em alguns casos, ainda detinham um grau superior de conhecimento, controle e autonomia sobre os meios e métodos de trabalho - pensemos por exemplo nos pequenos comerciantes ou prestadores de serviços locais). Estas formas, que a cada instante se mostravam mais e mais arcaicas quando confrontadas aos métodos mais modernos de racionalização do trabalho e da administração dos negócios e da produção, em breve se tornariam realmente jurássicas. Os integrantes sobreviventes desta rede eram, sim, os últimos dinossauros de uma era, não porque esta deixara de existir, mas porque transmudara suas formas num processo em geral percebido como "natural", "evolutivo" e "inevitável". A obsolescência destes trabalhadores enferrujados, que cotidianamente se defrontam com novas leis e imperativos em permanente mudança e aos quais 
não se adequarão (se é que o farão) sem enorme dificuldade, não faz senão iluminar a parcela do "velho" contida no "novo" que se impunha. Noutros termos, as redes de organização que operavam no sub-mundo do trabalho lembravam que o arcaico não existia como mera oposição aos recentes e constantes procedimentos de modernização implementados no mundo do trabalho ${ }^{47}$; ambos, arcaísmo e modernização, eram, de fato, elementos constitutivos e não mutuamente excludentes, que evidentemente qualificavam o sistema ao qual pertenciam.

Weegee, que operava entre estes dois universos era, como vimos, um híbrido entre a lei e o delito, mas também entre o arcaico e o moderno. Daí advém a alta voltagem de suas energias criativas e artísticas, ou seja, da posição "privilegiada" de seu ponto de vista, o mais adequado possível para informar, a partir de elementos antigos, o nascimento de uma nova estrutura em formação e consolidação. Em outras palavras, a combinação entre a memória encerrada nos modos que valorizam maior cooperação no universo do trabalho, que rapidamente se dissolviam, e os novos métodos desenvolvidos pelo aparato da indústria da notícia neste mesmo universo informam a natureza e o caráter da modernização e a lógica do cotidiano, mas também, como pretendo argumentar adiante nas considerações que farei sobre suas imagens, a elaboração ou fabricação de modos subjuntivos de concepção de novas possibilidades sociais, artísticas e políticas, numa arte compósita porque desde o princípio esforço coletivo e organizado de uma classe para o conhecimento do mundo material no qual está inserida. A "para-normalidade" de Weegee é, então, o saldo rentável

\footnotetext{
47 No Brasil, a relação entre arcaísmo e modernidade no âmbito do trabalho foi discutida em diversos contextos. Gostaria de ressaltar a ênfase e importância do tema na obra do arquiteto Sérgio Ferro, o "primeiro a apontar que o caráter atrasado da autoconstrução nas periferias estava diretamente associado ao padrão de industrialização do país, e que esta forma rudimentar de provisão habitacional, baseada na economia e esforço dos próprios trabalhadores, colaborava para a redução de seus salários no setor moderno. É deste modo que a produção de um valor de uso, a casa feita pelo morador, aparece socialmente como valor de troca - pois permite que se abrigue a baixíssimo custo uma mercadoria especial: a força de trabalho. É assim que 'a produção aparentemente marginal revela o sistema totalmente inclusivo'”. A esse respeito, ver ARANTES, P. (org.). Sérgio Ferro - arquitetura e trabalho livre. São Paulo: Cosac Naify, 2006.
} 
da operação de adição que soma a atividade de um coletivo, o ponto de vista privilegiado do trabalhador e, no seio do aparato cultural, o desenvolvimento das forças produtivas das quais faz uso amplo e irrestrito (por exemplo, da criação e aperfeiçoamento do flash sincronizado e do tamanho das câmeras fotográficas que, agora portáteis, diminuem em dimensão e peso). O girar de um botão ou o "click" fotográfico permite agora que uma determinada experiência sensibilize uma superfície sensível, a chapa fotográfica, impressionada por uma realidade que exige seu registro.

Em 1940 Weegee inicia seu relacionamento com um novo tablóide que começara a circular em Nova York no mesmo ano, o PM Daily. Como profissional freelance, tinha a liberdade de escolher entre as seguintes tarefas: 1. a partir das pautas diárias e semanais selecionadas pelo jornal, escolher as histórias ou eventos que mais lhe interessassem cobrir, 2. utilizar o teletipo policial para, a partir das informações recebidas, selecionar as histórias que documentaria ou 3. circular pelas ruas em busca de material que the parecesse interessante para publicação. Escolheu fazer todas elas; PM era o tipo de jornal que buscava envolver e motivar seus colaboradores neste nível.

Quando o pequeno PM aparece em cena, deparou com jornais de peso, verdadeiras instituições com circulação invejável e tradição e respeitabilidade "inabaláveis". The New York Times, Herald Tribune e Journal American (do conglomerado Hearst) enquadravam-se nesta categoria. Outros jornais, igualmente competitivos, completavam o quadro de veículos noticiosos, The Sun, World Telegram, The Post, os tablóides News e The Mirror, além de publicações em outras línguas, ídiche, italiano e espanhol, com circulação suficiente para figurarem em muitas bancas e o jornal do Partido Comunista, Daily Worker, facilmente encontrado por toda a cidade. PM se basearia em 
todos eles para tentar superá-los, não em tamanho ou circulação, o que evidentemente seria uma empreitada fadada ao infortúnio, mas no tipo e qualidade da informação que veiculava. Seria, em seus poucos anos de vida, uma escola de formação para um enorme contingente de trabalhadores do meio.

Ralph Ingersoll, um conceituado profissional do ramo jornalístico com fama de ressuscitar publicações agonizantes e incrementar ainda mais a receita daquelas bem sucedidas, decide angariar fundos para a publicação de seu próprio jornal. Usaria a reputação que construíra para convencer os membros da alta sociedade que conhecia e frequentava a participarem do projeto (graduarase em Yale e durante sua vida profissional expandira e consolidara o círculo do qual já fazia parte). O tamanho de sua influência e poder de persuasão pode ser avaliado pelos nomes que constam na lista dos colaboradores iniciais do jornal: o próprio presidente Franklin D. Roosevelt (que se beneficiaria do tablóide como veículo para sua propaganda política), Edward J. Noble (magnata da indústria e da televisão norte-americana), Marshall Field III (investidor e herdeiro da rede de lojas de departamento de mesmo nome, principal colaborador e acionista) e Huntington Hartford III (o jovem herdeiro da rede de supermercados A\&P precisava, segundo sua mãe, tomar um rumo na vida; ela providenciou o auxílio financeiro em troca de um emprego de "foca" para o filho no jornal, prontamente concedido) ${ }^{48}$. A proposta inicial apresentada aos possíveis investidores foi, naturalmente, concebida de modo a deixar bastante vaga a linha editorial que 0 jornal pretenderia adotar. Ingersoll sabia que para se viabilizar a campanha precisava ser suficientemente atraente em termos econômicos (o que significava garantias mínimas de algum lucro para os investidores ou, na pior das hipóteses, eventuais perdas iniciais) e políticos (leia-se "conservador" ou, no máximo, "liberal", na acepção que o termo ganhou nos Estados Unidos). Conseguiu, com a ajuda de alguns parceiros de trabalho, reunir os US $\$ 1.5$ milhão de dólares que necessitava para dar início às operações.

${ }^{48}$ Cf. MILKMAN, P. PM - A New Deal in Journalism, 1940 - 1948. New Brunswick, New Jersey: Rutgers University Press, 1997. 
Ingersoll já havia trabalhado em publicações como Fortune e Time, que sob a égide do editor Henry Luce (o mesmo fundador da revista Life) expressavam ideais extremamente conservadores, quando não abertamente reacionários (a revista Time, por exemplo, se posicionava claramente a favor de Franco49). Ingersoll pretendia criar uma espécie de anti-Time, um veículo de notícias fruto de um jornalismo alternativo, independente e explicitamente de esquerda, voltado à classe trabalhadora. A preocupação e dificuldades não se restringiam apenas em constituir uma equipe disposta a abraçar os valores do jornal, mas expressá-los visual e graficamente de modo a atender à necessidade e expectativa de seus leitores, ao mesmo tempo em que pretendia contribuir para a formação de um público cada vez mais exigente porque melhor informado. Para isso, olhou ao redor e buscou os modelos nos quais, ou contra os quais, se basearia.

Como profissional experiente do mundo da notícia, já sabia que o formato de tablóide não trouxera grandes modificações em relação aos jornais de tamanho padrão. Entretanto, guardavam algumas particularidades que the pareciam significativas o suficiente para serem futuramente consideradas: seu formato menor era ideal para a leitura em lugares fechados, por exemplo trens, metrôs ou ônibus, ou seja, os (poucos) locais onde a classe trabalhadora dispunha de oportunidade para fazer parte de sua leitura. Dado o caráter efêmero da notícia ou do próprio ato de ler, utilizavam-se de um tipo de diagramação que privilegiava uma síntese visual da informação apresentada, ou seja, uma linguagem "enxuta" que descartava possíveis excessos e maneirismos visuais, válida também nos termos literários ${ }^{50}$. De resto, colecionou uma série infindável de contra-exemplos.

\footnotetext{
${ }^{49}$ Cf. SCHIFFRIN, A. Dr. Seuss \& Co. Go To War - The World War II Editorial Cartoons of American's Leading Comic Artists. Nova York: The New Press, 2009.

50 A imprensa "séria" se ressentia profundamente da linguagem "vulgar" e "degradante" que se distanciava do vernáculo por ela ditado e não hesitava em expressar seu desprezo pelo que julgava inferior e de mau gosto. Em um de seus editoriais, o New Republic ataca frontalmente os tablóides: "ervas de uma floresta [jungle] no jardim do jornalismo". Cf. Who reads the tabloids? New Republic, 25 de maio de 1927. Citado em LEE, A. e MEYER, R. Weegee and Naked City. Berkeley: University of Califórnia Press, 2008, p. 22. A parcela condescendente da imprensa
} 
No que diz respeito especificamente aos tablóides, é certo que publicavam muitas imagens, mas a ligação com os textos que supostamente acompanhavam (ou mesmo entre si) era normalmente tênue e, na melhor das hipóteses, apenas sugeria posições ou opiniões editoriais. A quase totalidade das fotografias era mesmo de cunho abertamente sensacionalista e privilegiava a idéia do "mundo-cão" como mais uma mercadoria a ser consumida pelo público leitor. Nesta zona de atividade, as fotografias limitavam-se a criar um (falso) contexto visual para a legitimação fictícia de um pseudo-evento. Se aqui a fotografia "provava" a veracidade do "fato", este, por sua vez, contribuía para a autenticação da "verdade" atestada na imagem que o ilustrava. A relação de aparente simbiose entre ambos camuflava o real parasitismo da noção de notícia como fragmento espetacularizado para consumo fast food, cuja sobrevida é garantida pelos fluidos da indústria do entretenimento superficial e incoerente ${ }^{51}$.

Quanto aos demais jornais da cidade, Ingersoll compilou uma lista extensa de aspectos indesejáveis, que deveriam ser considerados para a concepção do novo jornal: 1. a pouca quantidade de notícias publicadas, 2. a enorme quantidade de anúncios e propagandas, 3. a pesada ou caótica diagramação visual que, frouxa e irregular, permitia a presença cada vez mais intensa dos anúncios publicitários (o que, naturalmente, fazia a felicidade dos departamentos comerciais dos jornais), 4. a enorme quantidade de notícias de caráter religioso, incluindo o resumo dos "principais" sermões proferidos na cidade, 5. a

entende o sucesso dos tablóides, mas reconhece que estes se restringem apenas a certas áreas da cidade, atendendo sobretudo a interesses do que descreveria como "subway minds", leitores sedentos por escândalos e visualmente ignorantes, dependentes das simplificações inexistentes nos veículos destinados à parcela do público mais "capaz" e "refinado" - a referência é evidentemente The New York Times. A este respeito, ver LEE, A. M. The Daily Newspaper In America: The Evolution of a Social Instrument. Citado em LEE, A. e MEYER, R. Weegee and Naked City. op. cit.

51 Para uma avaliação conservadora sobre o papel que desempenha a fotografia no aparato cultural moderno, ver POSTMAN, N. Amusing ourselves to death - public discourse in the age of showbusiness. Nova York: Penguin Books, 2005. 
importância dedicada às notícias sobre a alta sociedade e a alta costura ${ }^{52}, 6$. a vastíssima quantidade de anúncios de casamento e a ampla sessão de obituário, importantes fontes de renda para os jornais, 7. a extensa cobertura de notícias relacionadas ao mundo dos altos negócios e das bolsas de valores, 8. os sumários editoriais, 9. as pesadas edições de domingo, com muitas páginas mas esvaziadas de real conteúdo, compostas sobretudo das propagandas que faziam as lojas de departamentos locais, 10. os retratos fotográficos que, quando publicados, não passavam, em geral, de fotografias semelhantes às utilizadas para documentação oficial, como as de identidade ou passaporte, 11. as poucas notícias locais sobre a própria cidade ou seus bairros, 12. quase tudo que parecesse particularmente relevante aos grupos étnicos locais ou à classe trabalhadora não constava nas páginas da maioria dos jornais, 13. as manchetes ofereciam quase toda a informação relevante sobre o artigo que se apresentava ao leitor, 14. a coluna de fofocas era extensa e fazia o culto do mundo das celebridades, 15. muitas das matérias tendiam à repetição já que vários dos jornais não mantinham funcionários empregados em seus quadros, comprando as notícias de segunda mão de agências especializadas, e 16. o leitor normalmente precisaria executar um certo malabarismo para poder ler seu jornal sem que este se desmanchasse em suas mãos durante suas idas e vindas do trabalho ${ }^{53}$.

Uma vez identificado o tipo de jornalismo feito na cidade, Ingersoll precisava de um corpo de funcionários cuja visão fosse semelhante ao que concebia para $P M$. Dez mil candidatos se apresentaram para o preenchimento das duzentas novas vagas ${ }^{54}$. Com uma equipe cobiçada que incluía estrelas do jornalismo ganhadores do prêmio Pulitzer (George Lyon), Ingersoll cria uma aliança entre os diversos profissionais do jornalismo disponíveis no mercado de trabalho,

\footnotetext{
52 O correspondente americano do The New York Times em Paris responsável pela sessão de moda escreveu regularmente seus artigos sobre o universo da alta costura, publicados pelo jornal até o dia 02.06.1940, quando as tropas nazistas se aproximavam da cidade. Cf. MILKMAN, P. op. cit.

${ }^{53}$ Cf. MILKMAN, P. op. cit.

${ }^{54}$ Cf. SCHIFFRIN, A. op. cit.
} 
muitos dos quais membros atuantes no Newspaper Guild, o sindicato dos jornalistas fundado em 1933, os escritores do conglomerado Time Inc. (para quem, como vimos, havia trabalhado, e que reunia profissionais competentes que não necessariamente partilhavam das idéias conservadoras expressas na publicação) e intelectuais ligados à Frente Popular, sobretudo o círculo em torno de Dashiell Hammett e Lillian Hellman. Alguns dos nomes que passaram pela redação do jornal incluem Louis Kronenberger, o famoso crítico do The New York Times, William McCleery, editor de fotografia, Leo Huberman, comentarista de questões ligadas ao mundo do trabalho, o imigrante russo Max Lerner, uma das figuras de maior visibilidade da Frente Popular, o conhecido cartunista Theodor Geisel e tantos outros: Erskine Caldwell55, Margaret Bourke-White, Dorothy Parker e Alan Campbell. O inicio da publicação do jornal foi sucesso imediato. Neste cenário, os novatos também tiveram sua chance. Os executivos de PM compreendiam a necessidade da formação e expansão de mão-de-obra especializada para garantirem a continuidade da empreitada. E o jovem Weegee se beneficiaria desta constelação de fatores.

Aliando a qualidade técnica e artística das imagens publicadas em Life ${ }^{56}$ ao estilo de diagramação sofisticado do New Yorker, o jornal inovou como nenhum outro no quesito utilização de imagens. Afinal, $P M$ significava "Picture Magazine". Aos profissionais que preferiam não ter contratos exclusivos, prestando serviços como freelance, o jornal pagava um salário fixo, além dos

\footnotetext{
${ }_{55}$ Autor do romance Tobacco Road (A estrada do tabaco, de 1932), best seller também no teatro e no cinema, com filme de mesmo título de 1941 dirigido por John Ford.

${ }^{56}$ A revista Life era certamente a publicação de maior sucesso e importância no universo das revistas ilustradas e um modelo para muitos outros veículos de mesmo tipo. A diagramação inovadora, o uso criativo das fotografias em reportagens ilustradas, as famosas photographic essays (verdadeiros projetos fotográficos que se pretendiam comentários visuais sobre assuntos da história norte-americana contemporânea), o desenvolvimento de procedimentos técnicos que garantiam a alta qualidade de reprodução do material visual publicado (o aperfeiçoamento das técnicas do meio tom), a interação entre textos e imagens e os processos coletivos de trabalho fascinavam e influenciavam revistas como Look, Pic, Click, Picture, Peek e, como estas, tantas outras menos conhecidas. PM Daily pretendia tomar as conquistas técnicas e estéticas de Life como modelo para, a partir delas, veicular o ponto de vista da classe trabalhadora. Para referência específica à história da revista Life e sua produção fotográfica, ver EDEY, M. e SULLIVAN, C. Great Photographic Essays from Life. Boston: New York Graphic Society, 1978.
} 
extras por tarefa contratada (incluindo cada fotografia comprada, independentemente de sua publicação). Esta situação, única no universo jornalístico da época, permitiu que muitos de seus parceiros, e Weegee estava entre eles, gozassem de uma inédita liberdade financeira, aliada àquela ligada às condições de trabalho oferecidas pelo jornal, para realizar seu trabalho. No que tange às fotografias, o texto não se sobrepunha em importância às imagens. O intuito era a associação de linguagens para a melhor expressão da idéia desejada. Frequentemente aquele que fotografava um evento ou situação também escrevia o texto que acompanhava as imagens publicadas, não raro com a ajuda ou em parceria com outros colegas. Com uma espécie de "dream team" do jornalismo local ao alcance de sua mão, Weegee rapidamente aprenderia e desenvolveria modos de comunicação e expressão escritos e visuais que privilegiariam a descrição e o comentário do fato.

No dia 18 de abril de 1941 PM publicou uma matéria intitulada "Weegee fotografa a sociedade no Waldorf" (Figura 23). O artigo introduz e sublinha, já na manchete, a presença do fotógrafo que cobriu o evento. A disposição gráfica das imagens, todas em plano frontal57, é feita do seguinte modo: a página da esquerda mostra, no canto esquerdo superior a pequena foto de uma garrafa de champanhe sobre uma mesa num plano detalhe. A legenda para a imagem: "O champanhe custava dez dólares por garrafa. Eu mesmo prefiro malte com

${ }^{57}$ Quanto à distância entre a câmera e o objeto fotografado, os planos fotográficos podem ser: geral (quando mostra o cenário completo), de conjunto (ao retratar um grupo de pessoas), médio (ao mostrar um trecho de ambiente), americano (quando um único personagem é enquadrado da cabeça até sua cintura ou joelho), primeiro (quando o enquadramento utilizado é ainda mais fechado que o plano americano), close-up (quando apenas o rosto é fotografado) e detalhe (quando uma parte do corpo do retratado ou apenas um objeto aparece na cena). Quanto ao ângulo vertical, os planos são: plongé (ou picado, quando a câmera se posiciona acima de seu objeto, que portanto é visto em ângulo superior) e contre-plongé (ou contra-picado, quando ocorre o contrário e o espectador vê o objeto de baixo para cima). Quanto ao ângulo horizontal, temos: frontal, lateral, traseiro, plano de $3 / 4$ (um plano de ângulo intermediário entre o frontal e 0 lateral) e o plano de $1 / 4$ (um plano intermediário entre o lateral e o traseiro). 
petiscos para acompanhar". Ao lado, um breve texto escrito pelo próprio fotógrafo. À direita, duas imagens no canto direito superior em plano americano, a primeira de uma celebridade do mundo da moda e a segunda de uma socialite com um sapato translúcido na mão. As legenda dizem, respectivamente, "Ika Chase presidiu o desfile de moda. Eu a reconheci dos noticiários de cinema [newsreels]" e "A senhora Francis T. Boyd ganhou este sapatinho de cristal na competição da valsa". Abaixo, duas fotografias maiores que tomam o restante da página. A da esquerda é o retrato, também em plano americano, de uma socialite, que com sorriso estampado, véu e coroa encara o fotógrafo e mostra seu vestido. Aquela da direita revela, em plano médio, um senhor distinto em trajes de gala por trás de uma corista, vestida como cocote em pose de baile. A legenda para as imagens: "Polly Harvey brilhou no desfile de moda como uma Cinderela moderna" e "Allan Corelli ajudou a bailarina Marina Franco a entrar em sua fantasia de pavão." Na página da direita, uma enorme fotografia em plano de conjunto toma todo o espaço e proporciona ao leitor uma visão geral do salão de baile. Vários dos casais que dançam encaram o fotógrafo. Como última legenda: "Mil e duzentas pessoas estavam lá. Os ingressos custavam a partir de cinco dólares. O dinheiro foi para a Associação Nacional de Creches, S.A."

O texto do autor corrobora a descompostura injuriosa dos fotografados, reiterada pelo sarcasmo das legendas. "Não sei por que, mas fui escalado para cobrir o baile da Cinderela", inicia de modo jocoso seu artigo, anunciando ao leitor quem escreve e que o fará com métodos distintos daqueles utilizados pela imprensa dita especializada. Depois de informar o público que obtivera recomendações expressas do editor de coletar "muitas fotografias de moda", advertindo-nos que está aqui a trabalho, Weegee inicia a apresentação das personagens. "Encontrei Ilka Chase, que fala sobre moda no rádio, e perguntei-Ihe: 'Como um repórter policial deve andar por aí [go about] tratando de moda?' "Apenas descreva o que vê", responde a entrevistada. A linguagem coloquial que estabelece proximidade com seu leitor e a atitude "anárquica" do repórter zombeteiro perante o mundo grã-fino ridicularizam o evento e seus participantes de modo singular. Invade a 
festa como penetra, um universo ao qual ressalta não pertencer, escarnece de sua artificialidade e decadência elegante e, como se não bastasse, afronta verbalmente os presentes, descritos como animais, cangurus, galinhas e pavões (nem mesmo as vendedoras de cigarros escapam a seu escárnio, segundo Weegee, "Park Avenue Girls"). Mas ainda havia as imagens.

No decorrer da carreira profissional, o fotógrafo aperfeiçoara os procedimentos que conhecia desde o tempo em que retratou as crianças pobres do Lower East Side. Como muitas de suas imagens eram feitas à noite, precisaria sobretudo aprender a manusear com precisão o flash fotográfico. Com a habilidade técnica que lhe era peculiar, aprendeu e desenvolveu procedimentos técnicos quase infalíveis para produzir fotografias que apresentassem as qualidades necessárias para publicação mesmo sob as condições mais adversas de iluminação. Combinava o uso do flash acoplado à câmera a procedimentos como fechar o diafragma para posições como f16, o que significa ganho na definição geral da imagem e ajustava a velocidade do obturador para 1/200, garantindo que movimentos bruscos do objeto não seriam registrados pela câmera como "borrões", interferindo na legibilidade da cena. Costumava se posicionar a cerca de três metros de seu assunto, uma distância que estabelecera como padrão para poder responder a todo tipo de situação com a rapidez e as possibilidades de ação ou reação que as cenas exigiam. Assim estaria praticamente garantida a legibilidade da cena, que por sua natureza e condições de representação não era jamais considerada a partir de modelos pré-concebidos. Captaria deste modo a instantaneidade e a transitoriedade de cada momento. A tudo isso, soma-se o uso do filme infra-vermelho, que the permitia fotografar sem a utilização do flash, caso não pudesse ou não desejasse ser notado ou, a este combinado, na criação ou intensificação de determinados efeitos desejados. Depois de produzidas, as imagens seriam ainda manipuladas em laboratório, da revelação do filme à ampliação das fotografias - Weegee intervinha ativamente em todos os estágios da produção. 
Às habilidades desenvolvidas como escritor somam-se aquelas do fotógrafo, que não perderia a oportunidade de criar os efeitos visuais que comentassem e adicionassem significado ao texto, embalando, como uma trilha sonora executada por um afinado Stradivarius, o baile de gala da fina flor da sociedade nova-iorquina. Pois, na condição de especialista no assunto, decidira seguir à risca o conselho dado pela expert em moda. E os retratos fotográficos dos convivas não eram nada lisonjeiros. Utilizando-se dos recursos acima, especialmente do uso particular que fazia do flash em sua combinação com o filme infra-vermelho, o fotógrafo congela as personagens, misto de manequins em vitrines de loja de antiguidades e bonecos articuláveis num museu de cera em dia de festa fúnebre. A dança macabra se revela em cada uma das imagens e soma forças em seu conjunto, graças também à diagramação e montagem propostas para a matéria. O retrato da garrafa escura de champanhe no alto à esquerda, fria e hirta, recebe iluminação idêntica à sua rima visual, a vedete coberta de branco que se encontra na diagonal reta traçada pelo olhar do leitor, num movimento que percorre a página do canto esquerdo superior ao canto direito inferior. Pela ação de um flash agressivo, luz que invade e domina o espaço sem reconhecer ou respeitar fronteiras, o mesmo brilho que reflete 0 vidro da garrafa é reproduzido no braço da mulher. É ele quem consolida as semelhanças estruturais entre ambas, sublinhando suas curvas "sensuais" e as reduzindo a seu mínimo denominador comum, o sex appeal do inorgânico. A ridicularização da representação tradicional do nu (inclusive nos termos pornográficos) e a sensação tátil da mercadoria são os elementos que organizam a ordem visual construída pelo fotógrafo. Na cena, a mulher é corista, portanto uma trabalhadora de quinta categoria no mundo do showbizz, e um bem à venda, um bibelô de vitrine, uma Olympia moderna sem poder de negociação. Em suma, uma formulação visual do trabalho vivo suprimido e da prostituição geral do trabalhador. A violência do espetáculo continua. O homem que a acompanha é seu contraponto visual e também "ecoa" a garrafa. Ambos adornam-se com trajes escuros, de gala; a garrafa, como o homem, também se nos apresenta vestida num smoking haute couture. As legendas e texto se 
complementam e se somam às fotografias numa operação que retoma e atualiza, agora pelas lentes do trabalhador da indústria da notícia, tanto as descrições animalescas que fazia um Grandville sobre a sociedade francesa do período ${ }^{58}$ como o comentário ácido e impiedoso sobre o mundo do espetáculo que fizeram tanto o Zola como o Manet de Nana (o romance data de 1880 e a tela de 1877).

Analogamente, as "princesas" da noite, as senhoras Francis Boyd e Polly Harvey, formam outro díptico, representadas como uma massa branca e empastelada contra um fundo negro, numa diagonal oposta à primeira. A diferença brutal entre os alvos brancos e o negro profundo parece catapultá-las para fora da imagem, produzindo um efeito de estranha aproximação entre as figuras e o leitor. São elas que saíram da imagem ou nós que adentramos este universo? Num ponto intermediário, misto de sonho e pesadelo, escrutinamos as figuras de "conto de fada". Certas zonas erógenas como a boca e os seios de Polly ganham saliência insuspeitada e status de fragmentos autônomos. Seu rosto espectral, emoldurado por cabelos negros que não parecem pertencer àquele corpo, é máscara plástica que se desfaz por ondas de luz emitida pelo flash do fotógrafo. Sobre a cabeça, uma coroa real e o véu branco que envolve a figura, destacando-a ainda mais do fundo e contribuindo poderosamente para o embate entre brancos e negros. O que deveria ser tule diáfano entre luzes divinizantes torna-se matéria densa, modelada - ou esculpida - coisa que é coisa (Daumier). O braço que repousa sobre o emplaste que chamamos de vestido simplesmente não pertence à dona. Congelada num espaço exíguo e abstrato, Polly é ao mesmo tempo retesada e frouxa, uma marionete estacada e desarticulada cujos fragmentos parecem intercambiáveis. No sorriso, a pseudonaturalidade e estilização, materialização da linguagem gestual que dá a ver um

\footnotetext{
58 A esse respeito, ver GRANDVILLE, J. J. Vie Privée et Publique Des Animaux. Paris: J. Hetzel, Librarie-Éditeur, 1868. GRANDVILLE, J. J. Les Metamorphoses du Jour. Paris: Garnier Frères Libraries-Éditeurs, 1869.
} 
riso contorcido de vítima ${ }^{59}$. O sapato de cristal de seu duplo na fotografia acima é um acessório de acessório.

$\mathrm{Na}$ última imagem o êxtase do baile: uma massa fria e indistinta tenta em vão mover-se numa atmosfera congelada de caos, soterrada por imensos blocos negros que compõem o ambiente, as portas ao fundo, as paredes do hotel elegante, o tablado, as vestes dos convidados e até mesmo o ar, que neste universo transubstancia-se em matéria. Os gestos são todos automáticos e apontam simultaneamente em direções opostas num vazio obscuro (os braços, cabeças e olhares jamais coincidem). Dos poucos rostos visíveis, dois olham diretamente para a câmera, reconhecendo a presença do estrangeiro.

Por este modo de fotografar, que como uma câmera cinematográfica adentra e vasculha o espaço, e propõe, ou, por outra, impõe significados pelas vias da montagem às cenas apresentadas, o fotógrafo permite que o leitor articule um teorema. A caridade, motivo da festa, prognostica ainda mais desgraça. $O$ produto deste olhar cinematográfico colado na retina do público revela a inabilidade de atores que, num palco funesto, não passaram no teste da câmera de Weegee. Nesta performance, provaram-se amadores de quem os leitores de $P M$ não podem senão desconfiar. Para eles, a platéia grita: "Give them the hook!" O primeiro prêmio é para o fotógrafo, que, ao contrário, não improvisa seu número de modo irrefletido, mas orienta sua performance para seu público. Para fazê-lo ver os "bastidores" do evento, ele não espreme uma emoção para fora de seu recipiente original, a alma humana atormentada, mas técnica e artisticamente espreme esta emoção para dentro de seu novo recipiente, a obra de arte. Condensa esta informação a tal ponto que se permite exprimi-la nos poucos segundos que dura sua performance. As marcas de tensão visíveis em suas imagens, lavradas no papel como se utilizasse um buril, constituem 0 sistema estilístico que explicita crise e conflito em primeiro plano. A descarga

${ }^{59}$ A formulação é de Adorno. Em ADORNO, T. W. Prisms. Cambridge, Massachusetts: The MIT press, 1994, p. 98. 
expressiva que concentra seu vigor no golpe certeiro produz as energias que fazem do ato da comunicação um ato de comando. Esta fotografia não copia a realidade; oferece uma reação a ela, da qual somos convidados a participar. E Weegee exorta sua platéia, a classe trabalhadora, público alvo de PM: "Que minhas imagens vos perturbem!" O golpe que desfere exige recepção franca, livre da ortodoxia estilística que perdera de vista toda espontaneidade. O trabalhador-artista, consciente de estar sendo observado (e avaliado), clama para que seus sentimentos sejam considerados (e reproduzidos?) pelo espectador. Mas seu trabalho não é o de representar estes sentimentos, mas 0 de apresentá-los vivos e ativos para que o leitor, mais esclarecido com a demonstração da qual participara, opine como sujeito do processo - e com melhor juízo, posicionando-se. Sem dúvida há didatismo, que jamais poderá ser confundido com doutrinação. É precisamente por vias opostas que o fotógrafo reverte a proposta do baile das marionetes: do êxtase que se provara agonia, atinge, pela agonia, o êxtase como sinônimo de esclarecimento.

As origens da cooperativa independente de fotógrafos que posteriormente ficaria conhecida como Photo League remontam à formação da Worker's Film and Photo League em 1929 em Nova York, por sua vez uma ramificação cultural da Worker's International Relief (International Arbeiter Hilfe), fundada pelo comunista Willy Münzenberg, com sede em Berlim. Fotógrafos como Margaret Bourke-White, Berenice Abbott e Paul Strand, dentre outros sócios fundadores da primeira versão da liga, pretendiam, com seus filmes e fotografias, apoiar as lutas sociais durante o período da grande depressão. Em 1936, um ano após Weegee optar pela careira de fotógrafo freelance, uma cisão marca o fim da fase inicial da organização. A formação da Photo League acontece no mesmo ano pelas mãos dos fotógrafos Sol Lisbohn, Sid Grossman e Walter Rosenblum, que se inspiram na fotografia de cunho social produzida por Lewis Hine para criar as 
diretrizes que reuniriam seus novos membros em torno das atividades que 0 grupo pretendia desenvolver.

Concebida como um misto de escola, galeria, ponto de encontro e foto-clube, a Photo League reunia profissionais, amadores e interessados em retratar fotograficamente as condições de vida em Nova York sob uma ótica distinta daquela adotada pelos movimentos de cunho marcadamente "artísticos", uma reação explícita ao que entendiam como um esteticismo exacerbado que impedia a expressão de determinados conteúdos, a saber, a experiência do excluído e da classe trabalhadora na cidade. Nestes termos, a Photo League se insere no contexto da produção artística da vanguarda proletária característica da Frente Popular, composta, dentre outros, por pequenas galerias de arte, pelos chamados John Reed Clubs, organizações marxistas de escritores, artistas e intelectuais inspirados na obra de Reed, pelo coletivo dos compositores musicais e pelo sindicato dos artistas. O perfil da maior parte do público que frequentava a liga era semelhante àquele de seus fundadores: ativistas e simpatizantes autodidatas de origem pobre e imigrante, nascidos e criados nas regiões mais carentes da cidade, que compreendiam a necessidade de formação contínua e sistemática para aqueles que pretendiam continuar ou adentrar a carreira de fotógrafo profissional. Em torno desta organização experimental reuniram-se alguns dos mais importantes nomes da fotografia norte-americana: Berenice Abbott, Margaret Bourke-White, Eugene Smith, Helen Levitt, Arthur Rothstein, Beaumont Newhall, Richard Avedon, Robert Frank, Ansel Adams, Louis, Stettner e Edward Weston. As atividades promovidas pela organização incluíam discussões sobre temas da atualidade e seus possíveis modos de representação, aulas e cursos sobre técnica fotográfica e história da fotografia, conferências, exposições e a publicação mensal de uma revista, a Photo-Notes. Quanto às exposições fotográficas, não apenas incentivavam os alunos e membros a apresentarem suas próprias imagens, mas serviam também como fonte de inspiração, formando e expandindo o repertório visual, estabelecendo diálogo estreito com os temas abordados nos cursos e palestras 
sobre técnica e história da fotografia, além de promover discussão sobre a própria concepção do que deveria ser uma exposição fotográfica ou, no limite, uma exposição de arte, e as melhores formas de concebê-la e organizá-la. Também foram eles os responsáveis pelas mostras em torno de algumas das obras fotográficas mais influentes do século XX num momento em que nenhum daqueles mestres frequentava o grand monde da fotografia: John Heartfield, Lazlo Moholy-Nagy e Eugène Atget.

Todo o trabalho feito pela liga, de caráter marcadamente coletivo, resultava em projetos fotográficos que pretendiam expor uma determinada questão social ao mesmo tempo em que consolidava o aprendizado dos membros e alunos participantes. Alguns de seus projetos mais relevantes incluem: Portrait of a tenement (1937), 16th Street - a cross-section of New York (1940), Lost Generation - the plight of youth today (1940) e possivelmente o mais famoso e mais abrangente deles todos Harlem Document (1938-1940). Nas saídas a campo, cada um dos integrantes era incentivado a participar como um repórter fotográfico, ou seja, não apenas visitavam os locais, tomavam as imagens e retornavam à escola. Suas tarefas incluíam a realização de entrevistas com membros da comunidade local que pretendiam retratar, a elaboração de scripts que auxiliariam a concepção das imagens antes de sua realização, a varredura do terreno para avaliar as possibilidades e condições de execução do trabalho, a tomada das imagens, o debate com os outros integrantes do projeto em discussões de caráter técnico, estético e político e, finalmente, a elaboração de textos, legendas, gráficos, estatísticas, desenhos, caricaturas e disposição do material que deveria efetivamente compor a exposição, produto final do trabalho executado pelo grupo. Em termos sucintos, a liga pretendia, a partir de formas de organização coletiva, abordar temas relativos ao universo da classe trabalhadora e das minorias excluídas (o que grosso modo naquele contexto se equivalia) partindo de sua experiência, de seus modos de organização e a partir de seu ponto de vista. 
Tal proposta criava fortes pontos de contato entre a Photo League o jornal PM Daily. Ambos de fato estabeleceram diálogo intenso e produtivo. A viva atração entre Weegee e PM imediatamente se estenderia à Photo League. Afinal, ele era um exemplo de trabalhador imigrante que lia e produzia um jornal para seus pares, um "retratista oficial" da classe trabalhadora. Em abril 1941 participou de uma competição promovida pela liga, The Photo League Crazy Camera Ball, ficando em segundo lugar. Juntou-se em seguida à organização participando intensamente dos cursos e palestras (como aluno e professor). Em agosto do mesmo ano teve a oportunidade de realizar sua primeira exposição na liga. Ao levar a rua para as paredes daquela galeria concluiria o ciclo que prepararia 0 nascimento de seu primeiro livro.

Inúmeros painéis de papel branco pregados lado a lado nas paredes da galeria. Em cada um deles uma série de imagens coladas ou fixadas com tachinhas: fotografias, reproduções de insígnias oficiais, recibos de pagamentos, contra cheques, artigos de jornal ilustrados, desenhos e caricaturas. A palavra "murder", assassinato em inglês, está por toda a parte, assim como outras relacionadas ao mundo do crime e do trabalho daqueles envolvidos na sua representação - D.O.A. ${ }^{60}$ e C.O.D. ${ }^{61}$. Vários dos painéis trazem o nome de Weegee em letras maiúsculas e a imagem de um revólver recortado que flutua no papel. Do cano da arma a tinta aplicada à figura pelo próprio fotógrafo sugere sangue. As legendas para as imagens apresentam-se com a grafia do autor, escritas com caneta sobre as margens das próprias fotografias. Alguns dos painéis trazem no alto títulos como "Murder", "More Murders" e "Society" e parecem marcar estágios ou "capítulos" da exposição. A informalidade da

60 D.O.A. ou "Dead on Arrival" é um termo utilizado para designar o paciente que chega ao hospital em estado de óbito.

${ }_{61}$ C.O.D. significa "cash on delivery", ou seja, um sistema de pagamento em dinheiro no momento em que um produto ou serviço é entregue ou executado. 
apresentação e da ocupação do espaço convida o público a interagir de modo particular com o que the é apresentado. Era permitido chegar muito mais próximo das imagens do que nos tradicionais locais de exposição, museus ou galerias de arte consagrados. Tocar nos painéis ou nas fotografias também não era proibido. Todo este material, organizado sob a forma de exposição, recebeu o título de "Murder is my business", uma coletânea do que Weegee havia feito até então para os jornais da cidade.

A organização da exibição afronta, ponto a ponto, todas as regras e padrões tradicionais das mostras de fotografia ou exposições artísticas. De início, o local, que não era propriamente uma galeria concebida para um único fim, mas um salão multiuso com mesas e cadeiras que fazia as vezes de espaço de exposição sempre que necessário. O suporte de papel branco em paredes que não foram antecipadamente preparadas para receber as fotografias devidamente emolduradas com vidro e passe-partout causam no espectador que espera algum decoro com as normas correntes de exposição mais um impacto. As imagens coladas ou pregadas dão a ver o caráter provisório da exposição e das próprias fotografias, sugerem precariedade e revelam a presença física do fotógrafo (dentro e fora das imagens) e daqueles que o auxiliaram na elaboração e na execução da mostra, em suma dos trabalhadores envolvidos no projeto: a pintura mal-feita que sai do cano dos revólveres, a cola ou o percevejo aparente, a fragilidade do papel jornal, a série de fotografias abauladas e literalmente "expostas" a condições adversas de preservação, as impressões digitais deixadas no suporte escolhido e, como se não bastasse, os bastidores e 0 making of de todo o trabalho que precede a exposição, os contra-cheques que discriminam os serviços prestados e seus valores ("Explanation: Two murders; Amount: 35.00; Total: 35.00"), a imagem ampliada do documento oficial concedido a Weegee pela polícia ("Press") e as fotografias que circularam para promover a exposição mostrando, por exemplo, Weegee aplicando uma camada extra de tinta diretamente sobre uma das fotografias no intuito de salientar ainda 
mais, e de modo pouco "convincente", o suposto ferimento do retratado62. A intromissão da palavra escrita também não passaria desapercebida. A letra do artista aparece na margem de algumas das fotografias e painéis, invadindo um espaço que tradicionalmente não é o seu e que, sem grandes pudores, mostrase grafada à mão. Por toda parte outros textos e legendas explicativas interagem com o restante do material fotográfico, contemplando diferentes registros da língua que tendiam à informalidade, por vezes introduzindo e salientando "erros crassos" de ortografia. Um dos pôsteres, distinto de todos os outros em cor e tamanho, ligeiramente menor, trazia com letras brancas em fundo negro a seguinte frase: "This space reserved for the latest murders" (este espaço encontra-se reservado para os últimos assassinatos). As letras "s" das palavras "reserved" e "latest" foram propositalmente invertidas, como se escritas ou desenhadas por crianças que iniciam sua alfabetização, adultos iletrados ou estrangeiros pouco familiarizados com o alfabeto latino. Abaixo da frase no mesmo cartaz, uma folha branca vazia esperava pelas imagens que dariam continuidade ao processo que a legenda anunciava. Os títulos dos cartazes também marcavam presença forte. Ao lado do pôster "mal-escrito", Weegee posicionou um painel com o título de "Society", com imagens feitas sobre a alta sociedade local. Para um público minimamente atento e inquisitivo o efeito geral seria de imediato estranhamento e choque, suscitando indagações: "O que as fotografias de gente rica fazem ao lado de cartazes com imagens de acidentes e assassinatos?", "Quais as relações entre "murder" e "society", "dead" e "cash"?, "Por que um dos cartazes aguarda pelos últimos assassinatos?", "Então virão outros?", "Quem serão as vítimas, de que e como morrerão, quem as representará e como o farão?", "Por que as letras 's' estão invertidas nesta situação?", "Foi descuido ou inabilidade?", "Mas se por duas vezes aconteceu num cartaz, enquanto no seguinte a palavra "society" foi grafada segundo as regras da língua inglesa, o que isto significa?". E que dizer dos desenhos e caricaturas que enfeitam (enfeiam?) a exposição? A mescla de gêneros

\footnotetext{
62 As fotografias da exposição bem como as imagens relacionadas a sua publicidade podem ser encontradas em LEE, A. e MEYER, R. op. cit.
} 
considerados distintos, a aproximação de imagens e assuntos aparentemente díspares e os títulos que à primeira vista parecem conhecidos mas que logo apresentam ambiguidades somente ratificam o desconforto generalizado que proporciona a montagem da exposição, sancionado a todo instante por cada um dos painéis e corroborado pelo conjunto, formando um todo que é ponto de acumulação do material apresentado.

As opções estéticas feitas por Weegee em sua exposição, todas produto das condições materiais que se the impuseram e ponto de chegada de um percurso no universo do trabalho, demonstram a superioridade do alcance de certas formas, aquelas de caráter épico, para tratar de assuntos de semelhante natureza ligados ao coletivo dos trabalhadores, dos marginalizados e das relações sociais que Ihes dizem respeito. A revelação do artifício como artifício, a valorização e explicitação das marcas do trabalho, a insistência na montagem que chama atenção para si e exige do observador atenção e disposição para a construção de um raciocínio em torno da descrição de um processo e a recusa frontal da observação do decoro exigido pelas instituições responsáveis pela entronização da fotografia e das artes em geral balizam uma prática que busca sistematizar um modo distinto de apreender a realidade que postula essencialmente a total desacralização da fotografia como arte. Com o regicídio da fotografia clássica e dos clássicos usos que dela foram feitos (re)nascerá a arte como fotografia, que se utilizará inclusive desta forma de expressão estética e artística para conhecimento e avaliação do mundo.

Com sua exposição, Weegee dá indícios concretos de modos alternativos de articulação visual que permitem ver o que os métodos tradicionais de organização do material encobrem. A natureza e diagramação das fotografias nos jornais e tablóides, ilustrações efêmeras e não raro submissas aos textos correspondentes, libertam-se aqui das relações de assimetria e subordinação para, em termos de igualdade, produzir - ou recuperar - as mediações que permitirão ao observador perfurar a membrana das aparências para atingir a 
essência dos fatos. Ausentes o compromisso de representação do "real" pela mera cópia fotográfica da superfície do objeto e a relação de vassalagem entre imagem e texto, o que fora concebido como snapshot de fait-divers adquire status de documentação perene que expõe e questiona o próprio conceito de fait-divers - o banal, o corriqueiro, o que já é por todos conhecido. Noutros termos, se a disposição das imagens e dos textos num jornal tradicional não permite ao leitor efetuar as necessárias ligações entre as diversas fotografias e matérias publicadas, a busca por um patamar de compreensão da realidade, mais elevado, se faz necessária. Ouçamos Walter Benjamin:

"Se fosse intenção da imprensa fazer com que o leitor incorporasse à própria experiência (Erfahrung) as informações que the fornece, não alcançaria seu objetivo. Seu propósito, no entanto, é o oposto, e ela o atinge. Consiste em isolar os acontecimentos do âmbito onde pudessem afetar a experiência do leitor. Os princípios da informação jornalística (novidade, concisão, inteligibilidade e, sobretudo, falta de conexão entre uma notícia e outra) contribuem para esse resultado, do mesmo modo que a paginação e o estilo linguístico. (Karl Krauss não se cansou de demonstrar a que ponto o estilo jornalístico tolhe a imaginação dos leitores). A exclusão da informação do âmbito da experiência se explica ainda pelo fato de que a primeira não se integra à 'tradição'. Os jornais são impressos em grandes tiragens. Nenhum leitor dispõe tão facilmente de algo que possa informar a outro."63

É precisamente pela montagem "proto-televisiva" característica do jornalismo tradicional, que privilegia fragmentação, autonomização, serialização, instantaneidade, transitoriedade e obsolescência que Weegee articula modos alternativos para a concepção, diagramação e exposição dos materiais

${ }^{63}$ Cf. BENJAMIN, W. Sobre alguns temas em Baudelaire. op. cit. pp. 106 - 107. 
(re)apresentados. Na montagem proposta por ele em "Murder is my business" o espectador depara com as possibilidades de ligações impedidas por outras vias. Em "Society", por exemplo, este espectador deve articular relações entre as fotografias de membros da alta sociedade, a imagem do próprio fotógrafo assediando uma "vítima" e o artigo publicado por PM "Weegee fotografa a sociedade no Waldorf", parte integrante dos materiais em exposição. Todas as imagens de assassinatos que vira até então devem ser reavaliadas, pois acumularam camadas de significação com o passar da exposição. O espaço em branco que espera por mais fotografias parece impeli-lo ainda mais à ação: "O que você fará a respeito do que está vendo?", "Como completará o quadro e como serão suas imagens?" ou "Como contribuirá para que não mais precisemos produzir fotografias desta natureza?". Lembremo-nos que a exposição acontece num espaço misto. Nele, Weegee toma a linguagem ligeira da indústria cultural para falar nela, dela e para além dela para um público alvo bastante específico, o produtor de imagem, aluno ou instrutor, que se forma naquela escola.

Evidentemente apenas com o aproveitamento de certas "brechas", ou seja, graças às possibilidades de relativa liberdade de trabalho e criação propiciadas tanto pela Photo League como pelo jornal PM Daily, que não eram a regra e que em breve seriam suprimidos pela censura ou pela modernização dos processos de produção e comercialização da notícia, é que Weegee pôde, de fato, conceber e se servir de ferramentas com real poder de mapeamento, cognição e avaliação de sua hora histórica, o que não excluiria informações preciosas sobre as possibilidades e limitações do tipo de trabalho na indústria da notícia, o papel que nela desempenhava e a presença de elementos residuais numa nova estrutura que o fotógrafo percebia em fase de formação. No limite, as experiências ímpares de trabalho e contato com PM e com a Photo League, que atingem um ponto de acumulação com a organização de sua exposição, fornecem a Weegee um modelo ou padrão de concepção do que deveria significar a palavra "informação". A gaucherie estrutural da exposição, a 
zombaria e o escárnio do glamour museológico radicalizam inclusive os procedimentos mais corajosos dos veículos que serviram de escola ao fotógrafo. "Murder is my business" é sobre precariedade e processo: "murder is business" - o assassinato é um negócio, e aparentemente bastante lucrativo. E também sobre a transformação do sinistro em produção serializada de imagens equivalentes, rematadas para consumo imediato, descartáveis e prontamente substituídas. Qual é, afinal, a diferença entre os diversos cadáveres que se oferecem à vista numa sucessão sem fim, como objetos intercambiáveis, mercadorias, que num misto de horror e monotonia do mesmo se nos apresentam como num filme de gangster sem hora para terminar, em sequências padronizadas desprovidas de happy end? Weegee parte desta padronização e ratifica que é um funcionário raso desta indústria a quem cabe a produção deste tipo de imagem; portanto, que o assassinato é o seu negócio. Mas a repetição constante destas sequências, reorganizadas e refuncionalizadas por uma montagem que privilegia o comentário da ação, expõe a cegueira estrutural e pretende desembotar o olhar viciado do espectador/leitor - tudo isto também deve fazer parte do business de todo trabalhador consequente, inclusos os artistas. O crime, com interesse em si mesmo mas que não se encontra isolado da cidade que o produz, proíbe leituras estetizantes, fragmentárias ou moralizantes. O espectador, acossado, se vê coagido a aceitar, ainda que constrangido, o convite à reflexão. Esta arte, assentada sobre a lógica do cotidiano, sobre modos subjuntivos de conceber possibilidades alternativas de organização social, artística e política e sobre um esforço coletivo e organizado de conhecimento da realidade também é o business de Weegee, que por não abastecer o aparelho no qual se insere faz de "Murder is my business" um tablóide às avessas. Não se pretende fine art, muito menos apresenta-se como um instrumento de reforma social, papel desempenhado pelos fotógrafos da FSA - Farm Security Administration. Aqui a insistência é na apresentação de situações, nas quais as vítimas da cidade "que a despeito do abandono, há muito vivem em território trabalhado, para não dizer 
melhorado, pelo progresso"64, têm voz ativa e falam de assuntos sobre os quais o espectador deverá imperativamente se posicionar. As teses apresentadas em "Murder is my business" serão expandidas no que acredito ser seu "catálogo ampliado", que receberia o título de Naked City.

Naked City foi lançado em 1945. A idéia inicial, no entanto, data de pelo menos três anos antes, uma sugestão de Louis Stettner, um dos companheiros de Weegee da Photo League. Imediatamente após a primeira exposição do fotógrafo na instituição, Stettner reconheceu a necessidade e importância de organizar o material apresentado em forma de livro. E Weegee, que já era um fotógrafo relativamente conhecido no meio, tinha um histórico de flerte com o mundo das celebridades e pessoalmente adorava glamour, aprovou a idéia de imediato $^{65}$. Em abril de 1937 ele havia sido o assunto de uma matéria publicada pela revista Life, "Speaking of Pictures: A New York Free Lance Photographs the News". Em dezembro do mesmo ano, ganhou espaço na revista Popular Photography com um artigo dedicado a seu trabalho, "Free-Lance Cameraman". Em 1940 começou a receber o crédito para suas imagens publicadas na imprensa: "Photo by A. Fellig", "Fellig Photo", "Credit Arthur Fellig" e finalmente "Weegee". Em 1943 o Museu de Arte Moderna de Nova York, através de seu curador de fotografia Edward Steichen, um dos cardeais da "fotografia artística"

64 Cf. SCHWARZ, R. Cidade de Deus. In Seqüências brasileiras - ensaios. São Paulo: Companhia das Letras, 1999, p. 169.

${ }^{65}$ Stettner percebeu a qualidade do material produzido pelo colega e a necessidade de organizálo para fins didáticos, mas também reconheceu, no texto de abertura do catálogo da primeira retrospectiva dedicada a Weegee em Nova York em 1977, que o fotógrafo desde cedo se empenhava em criar uma persona, ferramenta que servia sobretudo para sua auto-promoção tanto no universo do trabalho quanto no grand monde nova-iorquino. "Weegee estava sempre ocupado com a criação de Weegee. Em meio a longas campanhas de auto-aperfeiçoamento, arquitetava um Weegee maior e melhor, tentando convencer o mundo não apenas a notá-lo, mas a curvar-se perante ele em elogios." Cf. STETTER, L. Weegee. Nova York: Alfred A. Knopf, 1977, p. 5. 
e o mais proeminente acólito de Stieglitz ${ }^{66}$, adquiriu cinco de suas imagens, exibindo-as numa exposição coletiva intitulada "Action Photography". Em maio do mesmo ano foi motivo de um artigo no Saturday Evening Post inteiramente dedicado a traçar seu perfil ${ }^{67}$. Em 1944 Weegee era um dos nomes presentes na exposição Art in Progress, uma importante exibição no MoMA de Nova York especialmente organizada para celebrar os quinze anos de fundação do museu. Segundo Weegee, na primavera deste mesmo ano a instituição acena-Ihe a possibilidade de proferir uma palestra, um convite prontamente aceito ${ }^{68}$. Não sabemos ao certo se o evento efetivamente aconteceu, uma vez que não existem registros oficiais da apresentação. O fato é que agora seu nome circulava nas altas esferas da produção e comercialização da arte e Weegee aos poucos passa a ocupar um lugar de destaque na maior vitrine da arte moderna norte-americana, contemplando a possibilidade de ver seu trabalho reconhecido pelos ciosos guardiões da alta cultura como parte integrante deste universo. E neste exato momento a idéia de um livro, uma espécie de portfolio do que produzira até então, era o visto que precisava para adentrar definitivamente o novo espaço, difundir seu trabalho e estabelecer-se como Artista consagrado. Weegee teria seus quinze minutos de fama e glória.

"Naked City tornou-se um sucesso. Fui comparado a Shakespeare, O. Henry, Hemingway, Dostoyevsky, Tolstoy e até mesmo a Weegee. Naked City vendia tão rápido que os editores tiveram que levar às pressas cópias extras para a Macy's de táxi. A livraria Scribner's da 5 a . Avenida dedicou uma vitrine inteira ao livro... quer dizer, depois que briguei bastante com eles. Eu disse: 'Olhe aqui, isso vai atrair gente

66 Sobre a relação artística entre os dois fotógrafos, ver DANIEL, M. Stieglitz, Steichen, Strand - Masterworks from the Metropolitan Museum of Art. Nova York: The Metropolitan Museum of Art / Yale University Press, 2010.

${ }^{67}$ Cf. KELLER, J. In Focus Weegee - Photographs from The J. Paul Getty Museum. Los Angeles: The J. Paul Getty Museum, 2005.

${ }^{68}$ Cf. FELLIG, A. op. cit. 
que nunca esteve numa livraria antes!' A livraria respondeu: 'Não queremos gente deste tipo.'

Fiz uma grande exposição no Museu de Arte Moderna e me tornei uma sensação do dia para a noite. O sucesso foi direto para minha câmera e também para minha cabeça. Meus preços subiram de cinco para quinhentos dólares por foto. Passei da delegacia para a sociedade [from the rogue's gallery to the social register]. Cobri eventos sociais e moda para Vogue, artigos especiais para Life, coronéis da indústria para Fortune e adolescentes para Seventeen."69

As duas versões de Naked City, lançadas simultaneamente, foram unanimemente aclamadas pela crítica. A primeira, para a qual não houve grandes considerações, era uma versão para os "populares"; em estilo pulp, de capa mole e conteúdo resumido era vendida por vinte e cinco centavos de dólar, consistindo numa breve seleção das imagens que constavam na edição integral. Usando linguagem simplificada, de fato incorreta segundo a norma culta da língua inglesa, trazia uma citação com elogios ao livro comparando o fotógrafo ao escritor norte-americano do século XIX O. Henry ${ }^{70}$. A segunda e mais importante, destinada a platéias "seletas", consistia na apresentação integral dos textos e imagens como concebida originalmente por seu autor. Ambas as versões recriavam o efeito visual obtido pela reprodução das fotografias em papel jornal, suporte para o qual foram originalmente concebidas, porém a edição integral diferenciava-se de várias maneiras. Seu público era, em certa

${ }^{69}$ Cf. FELLIG, A. op. cit. p. 85.

70 "Weegee fotografa como O. Henry se este tivesse uma câmera" [Weegee photographs that O. Henry might have done if he worked with a camera]. Cf. LEE, A. e MEYER, R. op. cit. p. 40 (meus grifos). 
medida, determinado pelo preço cobrado por exemplar, quatro dólares, o que não chegava a ser propriamente caro, mas significativamente acima do preço da edição resumida. A diagramação artística do material era muito mais sofisticada e aludia a referências modernistas: na capa dura, a montagem remetia à estética do construtivismo russo do início do século XX e anunciava, com fotografias de Weegee recortadas no formato de cada uma das letras, o título da obra. Ao contrário da edição resumida, o livro e o fotógrafo eram louvados com o inglês castiço de uma suposta autoridade do mundo das artes, ninguém menos que Nancy Newhall, membro do departamento de curadoria do MoMA de Nova York quando do lançamento do livro: "Graças a seu timing, Weegee transforma os lugares comuns de uma grande cidade em extraordinários documentos psicológicos" ${ }^{\prime 1}$. Também trazia uma introdução, redigida pelo editor de fotografia de PM Daily, William McCleery, que, em certa medida, apenas explicitava o que sugeriram The New York Times, Saturday Review of Literature, Time, Newsweek e Washington Post: o mundo assistia ao nascimento de uma estrela de quinta grandeza, que já chegava com as credenciais de Artista com "a" maiúsculo"

Uma página em branco e, em seguida, duas outras, todas sem numeração. No que posteriormente perceberemos ser as páginas dois e três - o livro já começara mas a leitura ligeira não se deu conta - a presença de duas

${ }^{71}$ Cf. LEE, A. e MEYER, R. op. cit. p. 40.

72 Cf. WEEGEE. Naked City. Nova York: Da Capo Press, 1973, p. 6. Para minhas considerações sobre Naked City utilizei-me de uma edição fac símile da versão original completa publicada em 1945 pela editora Essential Books. A escolha do material foi motivada não apenas por sua disponibilidade e acesso para a pesquisa, mas sobretudo pelo fato do autor ter aqui articulado, com relativa autonomia, seus textos e imagens do modo como originalmente os havia concebido, esquivando-se de possíveis restrições ou imposições de caráter mercadológico condicionados à publicação da obra pela casa editorial responsável. Como vimos, é somente a partir deste relativo grau de liberdade que goza o fotógrafo para conceber e organizar seu material em forma de livro, em conformidade com o semelhante grau de liberdade que lhe permitira tanto a produção de suas imagens para os jornais e tablóides quanto sua organização para a exposição da Photo League, que registrará, como fizera em "Murder is my business", modos alternativos de demonstração de processos relativos à experiência do excluído a partir dos imperativos ditados pelo mundo do trabalho. 
fotografias, uma "unidade" subdividida em duas partes (Figura 24). As imagens retratam um perfil clássico de Nova York, a silhueta de uma de suas famosas pontes e de alguns de seus arranha-céus, vistos ao longe. A maior delas é um retângulo de $14,5 \mathrm{~cm}$ de comprimento por $16,7 \mathrm{~cm}$ de altura que ocupa quase toda a página "2" e concentra-se na apresentação da ponte e do céu da cidade. Muito próxima, quase na dobra do livro na página "3", uma fotografia de $5,9 \mathrm{~cm}$ de comprimento por $17 \mathrm{~cm}$ de altura é dedicada a mostrar a sequência da cena, os edifícios e outra parte do céu. À direita desta imagem, em letras garrafais e sob fundo branco, uma lista de palavras dispostas na seguinte ordem, uma abaixo da outra: "Naked", "City" e "BY WEEGEE". O leitor trava assim seu primeiro contato com Naked City, que já nas duas primeiras páginas condensa informações fundamentais que norteará a leitura atenta e bem informada da obra: comunica o propósito do livro nas imagens e no texto, explicita os procedimentos formais necessários para atingi-lo e avisa que o leitor interessado no trajeto proposto deverá executar um tipo de trabalho bastante específico, essencialmente de articulação e montagem, para a partir do produto de seus esforços derivar e expandir as reflexões que o livro pretende suscitar - ele será, afinal, um membro ativo neste processo. $E$ tudo isso pelas lentes de alguém com o estranho nome de Weegee, que se apresentará nas páginas seguintes.

Ao traçarmos uma linha imaginária que divide horizontalmente a primeira imagem retangular em duas porções iguais percebemos que a parte inferior é essencialmente composta por gigantescas massas negras, ou seja, o perfil da ponte e suas estruturas metálicas, que se estendem de um extremo a outro da fotografia. Sob a ponte, o que inferimos ser o rio Hudson, uma massa profundamente escura e sólida, uma "parede" negra pregada à imagem e pontuada por diversos focos de luzes brancas de grandezas e formatos distintos (pensemos em Barqueiros em Argenteuil, 1874, de Manet). A disposição dos maiores pontos de luz à direita e o enquadramento geral da imagem, que privilegia maior concentração de blocos negros no canto direito inferior e "desalinha" a base da ponte e o horizonte, parecem imprimir um sutil 
desequilíbrio ou instabilidade à fotografia. De resto, os pontos de luz sugerem a iluminação proveniente do que imaginamos ser embarcações que navegam pelo rio, exceto pelos pequenos focos de luz na ponte, prováveis postes de iluminação que guiam o olhar do observador até o centro da construção, onde obrigatoriamente depara com a maior de todas as fontes luminosas. Esta chama branca, desconhecida, atrai a atenção para si por seu tamanho, pelo contraste de cor com as outras formas a seu redor - ela se posiciona entre duas estruturas da ponte, sua base estreita e seu espesso pilar principal, ambos em formato retangular e muito escuros - e por sua função na imagem. O reflexo da luz no rio remete à ideia de um sol que insiste em nascer na escuridão generalizada em meio à atmosfera lúgubre que a fotografia sugere, corroborada por toda a parte superior da imagem, um enorme céu vazio e enegrecido, que pela granulação do filme e a aspereza do papel aparece como atmosfera densa, concreta e asfixiante, um miasma.

A segunda imagem sugere a continuação da ideia expressa na primeira. Os cabos de aço na ponte da primeira fotografia adentram o perímetro da segunda nas mesmas posições e altura, de modo a encaixarem-se perfeitamente formando linhas diagonais que saem de um espaço, continuam hipoteticamente no extra-quadro (Manet) e adentram o novo campo, indicando, assim, um encadeamento de "quadros" ou "fotogramas". Evidentemente, se as imagens têm tamanhos distintos, houve a preocupação de posicioná-las de modo a criar este "ajuste" na sensação ou percepção visual, como se o autor cuidadosamente acertasse a sintonia fina de uma engrenagem. Há, portanto, insistência na idéia de sequência, porém toda e qualquer naturalização de continuidade ou transição facilitada serão imediatamente solapadas. Se na primeira fotografia, logo abaixo dos mesmos cabos, uma fonte luminosa, de tamanho semelhante àquela no centro da ponte (e portanto suficientemente grande para ser ignorada) aparece como um semi-círculo acompanhado de seu reflexo no rio, ambos segmentados na margem direita, sua parcela "correspondente", a saber, o espelhamento invertido destes elementos, desaparece por completo na margem esquerda da 
segunda fotografia. O vácuo é ressaltado. Presente pela ausência, o elemento faltante exige que o observador retorne ao quadro anterior para verificação de suas primeiras impressões, movimento que sublinhará sua sensação de desconforto e estranhamento. No lugar do suposto reflexo na água, uma linha de luz branca grossa e contínua cruza quase toda a base negra da fotografia. Como uma pincelada marcada, conduz o olhar do observador obrigando-o a percorrer um determinado trajeto pelo "andar térreo" da imagem. No percurso, encontramos um outro "sol" acompanhado de seu reflexo no rio, ambos bem mais modestos em tamanho e intensidade de brilho que seu "eco" ou rima visual na primeira fotografia. A partir deste ponto o olho encontra uma série de pequenos focos de luz branca que o impelem para a parte superior da imagem. Colada ao que inferimos ser o rio da primeira imagem outra "parede" negra, desta vez recortada em forma de edifícios característicos da cidade. Ao subir os andares dos prédios, o olhar descobre que ao mesmo céu "matérico" da primeira imagem foi acrescida a enorme figura de um raio em forma de gancho, que rasga toda a extensão superior da fotografia, atinge um dos prédios de modo certeiro, ratifica a idéia de instabilidade e torna-se um elemento central para a compreensão do conjunto.

O fotógrafo certamente não está interessado na execução de vistas edificantes de cartões postais da cidade - o clássico pôr do sol não é bem vindo neste universo. A bi-dimensionalidade, a materialidade e o choque entre cores negam formalmente qualquer ideal "clássico". Mas Weegee avança um passo além na tentativa de construção do que acredito ser uma nova classicidade para a imagem fotográfica, desiderato para a edificação de modos alternativos de representação de um tipo bem específico de experiência societária. Como vimos, a bi-dimensionalidade e o choque entre cores e formas em suas imagens se dão essencialmente pela subversão da ortodoxia prescrita para o controle da luz, no seu caso, a combinação entre o flash fotográfico e o filme infra-vermelho. Neste breve conjunto de imagens, para o qual acredito ter se valido, dentre outros, de tais procedimentos, o fotógrafo parece insistir veementemente na 
representação das fontes luminosas, que sem disfarce ou artifício se apresentam como tal. O pôr do sol, figura tradicionalmente romantizada, não raro açucarada, vê aqui acidificadas sua habitual fotogenia e idealização. $O$ primeiro "sol" é pura luz que ofusca, metáfora da luz de Weegee concebida para aclarar relações e processos. Ela "renasce" na segunda imagem, modestamente em sua parte inferior, para imediatamente confirmar-se no agigantamento e na efemeridade do raio que não apenas fere mas devasta.

A energia deste raio de luz é análoga àquela contida no poder de revelação do flash de Weegee, que com sua câmera aplica ao instante um "choque póstumo". Pelo choque, princípio formal tanto para a execução de cada uma das imagens quanto para a sua apresentação numa montagem em termos cinematográficos (o "fotograma" que segue as duas imagens é a tela branca que anuncia o título e o autor da "película"), o fotógrafo mergulha no "tanque de energia elétrica"73 que é sua Nova York, para aí operar a desnaturalização de fenômenos tidos como naturais. Não é improvável que Weegee tenha efetivamente dividido em duas partes o que inicialmente concebera como uma única imagem. Ele normalmente utilizava-se deste procedimento toda vez que precisava vender mais fotografias, multiplicando elementos a partir de um único negativo (por exemplo, fotografando dois criminosos juntos e, através de manipulação em laboratório, produzindo imagens que os apresentassem separados, podendo, neste caso, duplicar seus ganhos). Se tomarmos tal suposição como verdadeira, poderemos afirmar que o fotógrafo re-trabalhou a segunda imagem, a partir da primeira, a ponto de inserir, salientar ou suprimir determinados elementos que chamariam atenção para si e para o trabalho executado. Ao escrever sobre a obra de John Heartfield, Sergei Tretiakov sugere que uma operação de montagem fotográfica se dá toda vez que o artista altera, conscientemente, o primeiro e mais óbvio significado que pode ter uma fotografia. Servindo-se de técnicas como a

${ }^{73}$ Gostaria aqui de explicitar a aproximação da produção fotográfica de Weegee, de seu início até Naked Ciy, aos desideratos para a arte moderna expressos por Baudelaire tanto em sua obra como em sua crítica de arte. Para tanto, utilizo-me sobretudo da leitura que fez Walter Benjamin da obra do crítico e poeta. Ver BENJAMIN, W. Sobre alguns temas em Baudelaire. op. cit. 
combinação de duas ou mais imagens, a inserção de desenhos ou formas gráficas, a aplicação de tinta ou adição de manchas significativas de cor ou a utilização de textos escritos o foto-montador esquiva-se de toda forma que se pretenda expressão "natural" de significados. A partir de modos literalmente construídos, este artista priorizará a leitura ativa da imagem fotográfica, que ao recusar a reprodução da realidade empírica sensível "desrealiza" a imagem fotográfica ${ }^{74}$.

Assim, a tempestade proposta pelo fotógrafo não é nada espontânea nem o raio um fenômeno desprovido de trabalho ou intervenção da mão humana. Cuidadosamente construídos, extinguem uma ordem, a da fotografia como cópia mimética do real ou como embelezamento estetizante, para em seu lugar erguer outra, a da fotografia como meio de cognição da realidade. Este raio insiste que toda arte consequente, fotografia inclusa, não deve buscar a imitação barata da natureza, muito menos seu embelezamento puro e simples mas, ao contrário, a desnaturalização de modos fossilizados de concepção do mundo, a começar pelo próprio desembotamento do ato de ver. Daí a insistência na instabilidade geral das imagens: o embate entre cores e formas suplanta a idéia de concretude "inabalável" dos grandes blocos negros, a ponte e os arranha-céus, no limite os ícones de civilização e progresso, expõe sua fragilidade e informa que o que parece "ser" na verdade "está". O raio é, portanto, a materialização de uma explosão que estilhaça, como numa composição cubista, a visão tradicional em milhares de pedaços. Um novo conceito de realidade emerge do epicentro da crise pela ação do artista, que é, como vimos, figura e expressão de um coletivo, dissolvendo toda atitude contemplativa para instaurar em seu lugar o engajamento ativo com um determinado tipo de experiência societária. A "beleza convulsiva" da qual falara Breton toma forma concreta nas fotografias que abrem Naked City. E é precisamente esta nova beleza que irá expor a deficiência do modelo clássico de representação. Pelas lentes do fotógrafo, o ambiente é

\footnotetext{
${ }^{74}$ Para as considerações de Tretiakov, ver LAVIN, M. [et alii]. Montage and Modern Life 1919 -
} 1942. Boston: The MIT Press, Cambridge, Massachusetts, 1992. 
transfigurado por um relâmpago sugerindo que a paisagem urbana irá pelos ares. A explosão anuncia o fim de um modelo e prenuncia outro. O fotógrafo molda o material pictórico com o qual trabalha como um oleiro modelaria a argila. Mas evolui do artesanato para as formas industriais de produção. $\mathrm{Na}$ "desordem" cognitiva elaborada em seu seio a alusão a instabilidades sociais, econômicas e políticas ainda maiores.

O conjunto das imagens sugere que os danos causados pela tempestade que se organiza pelas mãos e lentes de um conspirador profissional serão mais significativos e profundos do que poderá prever o leitor desavisado. A julgar por sua silhueta, a torre que recebe a descarga elétrica é um banco, o Bank of Manhattan Trust Building, também conhecido como Manhattan Company Building, hoje renomeado The Trump Building. O edifício localizado em Wall Street é um ícone da arquitetura e um cartão postal da cidade até hoje, porém nos anos trinta viveu seu apogeu na efêmera glória de ser o mais alto edifício do mundo (no mesmo ano de sua inauguração perderia a posição de número um para outro arranha-céu da cidade, o Chrysler Building, com quem competia pela primeira colocação numa corrida por publicidade, negócios e lucro). Em sua imagem, Weegee expõe e eletrocuta, com a fugacidade de um raio, nada menos que a fragilidade do que representa Wall Street que, ao menos na fotografia, não parece poder resistir à voltagem da descarga elétrica recebida (cerca de três vezes o tamanho do prédio atingido). A tempestade e o discreto raio, que em segundo plano abateram um dia a capela real de Versalhes no Sermão do Jeu de Paume de David (1791) fustigam agora no proscênio outra realeza na Nova York de Weegee. Cinquenta e seis anos mais tarde, e não muito longe dali, duas outras torres seriam literalmente postas abaixo. A atmosfera fúnebre das imagens não é senão a expressão da organização do terror. O raio, que também é gancho, avisa o leitor que o livro é produto de um tipo específico de trabalho que pretende retirar algo da cena da cidade - ainda que, por enquanto, simbolicamente. 
E para que não restem dúvidas, a fotografia que segue o primeiro conjunto apresentado é o retrato do "responsável" pela ação, o próprio fotógrafo, em formato de passaporte, com sua câmera e flash em primeiríssimo plano (Figura 25). O documento vem, assim, "autenticado" e atesta tanto a validade do projeto como a adequação dos procedimentos utilizados. No primeiro capítulo, "A book is born", Weegee revela que o nascimento do livro é produto do amor entre o trabalhador e seu instrumento de trabalho (a legenda para sua fotografia: "Weegee e seu Amor, sua Câmera"), da necessidade material de sobreviver na cidade e da fidelidade para com o material que se the apresenta, o que significa a produção de obras que aderem às leis do mercado e à linguagem industrial por necessidade, ao mesmo tempo que por dever de ofício fazem sua exposição crítica. As duas primeiras fotografias são apenas o newsreel que precede 0 longa-metragem (e, de par com um Welles, que também inicia seu primeiro longa metragem com um cine jornal, o fotógrafo pretende pôr em xeque inclusive os usos e funções tradicionais do newsreel). O que assistiremos será o diagnóstico acurado e a exposição de uma síndrome, aquela do "mal estar da civilização".

"Me falaram que minhas fotografias deveriam estar num livro, que são um grande documento social. Como fico muito sozinho, não pertenço a grupos e gosto de ficar na minha, eu não saberia dizer. Aí algo aconteceu. Houve uma enorme queda nos assassinatos e incêndios na cidade (meus dois best sellers, meu ganha-pão). Não pude entender isso! Com tantos milhões de pessoas, isso simplesmente não era normal. Mas pelo menos tive a chance de olhar novamente para as imagens que vinha acumulando. Postas juntas, pareciam formar um padrão. Colei as fotografias num 'boneco' e o deixei com os editores junto com uma nota: 'este é meu 
bebê... tome cuidado, por favor'. [...] Para mim, uma fotografia é uma página da vida e sendo assim deve ser real. ${ }^{.75}$

A visão é um tema central em Naked City. Como profissional que se utiliza primordialmente deste sentido, Weegee examina, nos termos e condições de sua prática, os possíveis modos e métodos de representá-lo fotograficamente que mais adequadamente permitem sua realização efetiva. Sua opinião sobre o significado da palavra "visão" inicia-se, como vimos, já nas páginas iniciais do livro e continuará no decorrer dos dezoito capítulos que compõem a obra. Cada um deles é dedicado à exploração de um tema, que como movimentos musicais distintos mas não alheios irão compor, pela via caleidoscópica do mosaico, a "estrutura musical" com a qual o leitor trava contato. Alguns destes capítulos parecem funcionar como "notas agudas" e "dissonantes", que na variação chamam atenção para si e anunciam que a "dinâmica musical" atingira um ápice na trajetória. Noutras palavras, é o movimento em crescente que permite a acumulação de material em quantidade para uma mudança qualitativa na articulação da "frase musical", com a decorrente elevação do patamar da reflexão proposta. Gostaria de examinar um destes pontos de inflexão, a saber, o oitavo capítulo, intitulado "Frankie".

"Frankie" é precedido por sete capítulos, nos quais o autor abordou, nesta ordem: 1. a leitura do fait-divers nos jornais da cidade e o torpor do sono e do sonho (capítulo 1, "Sunday Morning in Manhattan"”6), 2. os passantes curiosos

\footnotetext{
75 Cf. WEEGEE, Naked City. op. cit. pp. $11-12$.

76 O livro reforça no primeiro capítulo que os registros fotográficos apresentados não terão qualquer compromisso com a cópia fiel da realidade aparente dos fatos. Em "Sunday Morning in Manhattan", é impossível distinguir entre quem dorme, trabalha ou morre - todos parecem anestesiados por uma atmosfera de sonho, ou pesadelo, que domina o cenário urbano. Até mesmo os animais, duas (improváveis!) zebras e um elefante, sucumbem ao torpor generalizado que domina uma "Nova York que dorme" (pensemos nos paralelos com o surrealismo do René Clair de Paris que dorme, filme de 1925).
} 
sempre prontos a observarem alguma tragédia local, incluindo aquelas noticiadas pelos jornais de prestígio de Nova York (capítulo 2, "The Curious Ones"), 3. as vítimas dos incêndios na cidade, sobretudo aquelas dos tenements no Lower East Side, incluindo, com requintes de humor negro, a fotografia de um dono de edifício que chora "porque sua propriedade foi danificada"77 (capítulo 3 , "Fires"), 4. os assassinatos cometidos na cidade, o espetáculo que se tornaram para a população local, que os assiste literalmente de camarote, e a produção serializada de imagens violentas que pretendem satisfazer um apetite pantagruélico, fomentado pela indústria jornalística ${ }^{78}$ (capítulo 4, "Murders"), 5. mortes e acidentes violentos, contados em forma de conto de fada macabro ${ }^{79}$ (capítulo 5, "Sudden Death), 6. o funeral chique de um membro proeminente da sociedade local, nas palavras do autor, "a fashionable society funeral"80 (capítulo 6, "The Best People Go To Heaven) e finalmente 7. o capítulo intitulado "The Escapists...".

77 Cf. WEEGEE, Naked City. op. cit. p. 68.

${ }^{78} \mathrm{O}$ capítulo se inicia com a mesma fotografia do contra-cheque recebido por Weegee, exposta em "Murder is my business". Aqui, o fotógrafo estende a explicação no corpo do texto: "Recebi a nota acima com um cheque da revista Life. Vinte e cinco dólares pela fotografia do assassinato à direita... a outra fotografia que compraram era de um assassinato merreca, com poucas balas... então pagaram só dez dólares". A fotografia à qual se refere, ao lado do texto e da imagem na qual lemos "Two Murders, 35.00", mostra um tenement em Little Italy com pessoas apinhadas nas janelas e escadas externas de incêndio observando um corpo no chão rodeado por policiais. A legenda escolhida pelo fotógrafo: "Balcony Seats At A Murder" ("Camarotes num assassinato"). Cf. WEEGEE, Naked City. op. cit. pp. $78-79$.

79 Weegee inicia assim sua descrição do evento, logo abaixo da fotografia que abre o capítulo, um carro içado do rio por guindastes: "É uma linda noite de lua cheia..." Cf. WEEGEE, Naked City. op. cit. p. 88.

80 O capítulo é composto de apenas duas páginas, na da esquerda o texto e na da direita a imagem do caixão sendo carregado por três homens de fraque. Weegee não poupa sarcasmo, a começar pelo título, "Os melhores vão para o céu". No corpo do texto, as referências à notícia que ocupou "quase uma coluna inteira no New York Times", aos "Rolls Royces bonitinhos [cute] que chegavam com seus convidados [guests]" e aos espectadores, que da calçada assistiam a cerimônia escutando um cantor "com voz de marica" que entoava Oh, what a beautiful morning. O mundo do trabalho não se encontra ausente do evento. Sem motivo aparente para o desenvolvimento da narrativa, Weegee interrompe o enterro para mencionar os motoristas uniformizados, os carregadores profissionais de caixão (em destaque na fotografia) e os carregadores de caixas de carne para um certo restaurante, o "Hamburger Heaven", que logo começam a discutir apostas, corridas e as dicas dadas pelos bookies do New York Daily Mirror. Cf. WEEGEE, Naked City. op. cit. p. 92 (meus grifos). 
Os escapistas a quem Weegee se refere incluem de exauridos trabalhadores no universo do entretenimento popular e moradores pobres da cidade (o caráter auto-biográfico parece evidente) a personalidades do jet set internacional e da política local. O capítulo abre com o close de um vendedor uniformizado de cerveja que dorme durante seu trabalho num circo. A seu lado, na página seguinte, duas imagens retratam uma platéia que assiste a um espetáculo qualquer. No centro da primeira fotografia uma mulher dorme em posição semelhante ao vendedor na imagem anterior enquanto os espectadores a seu redor olham todos para cima como se assistissem a um show de trapezista. $\mathrm{Na}$ segunda, todos aplaudem mecanicamente o fim do número, inclusive a mulher que dormia. Os olhares já não convergem e os gestos parecem automáticos. Em primeiríssimo plano, nós com cordas brancas sobre fundo negro sugerem amarras de várias naturezas (explicitadas, como veremos, no próximo capítulo, "Frankie"). A associação entre as imagens faz delas um tríptico. Mesmo sem a certeza da informação, a sugestão é que todos se encontram no mesmo ambiente: durante um determinado número circense o vendedor aproveita para descansar enquanto a platéia "se diverte". A legenda para a primeira imagem reforça a idéia - "vendedor cansado num circo...". O texto, por sua vez, recomenda que esqueçamos os cupons de racionamento e as desilusões amorosas. Nada de ficar esperando pelos soldados que estão na guerra (referência à II Guerra Mundial), descritos como um tipo de boneco articulável, G. I. Joe, enorme sucesso entre as crianças da época. "Ria, é bom para você... Este é o tipo de fotografia que gosto de tirar... é engraçada, as pessoas vão rir e se divertir - quando tiverem dinheiro para comprar o ingresso" ${ }^{\prime 1}$. Na página seguinte, o mesmo baile que fotografara para PM Daily no hotel Waldorf-Astoria, presente também em "Murder is my business". A fotografia de plano geral da alta sociedade é contrastada com outra nos mesmos moldes, aquela de um baile na associação dos trabalhadores de minas. Os mais jovens demonstram evidente fascínio pela cantora que se apresenta no palco. O capítulo continua com imagens de shows de variedades, compara um casal branco que ri com outro

${ }^{81}$ Cf. WEEGEE, Naked City. op. cit. p. 94. 
negro, bastante sério ("vamos lá, ria também... não tenha medo... todos os homens nascem livres e iguais....82), retrata personalidades como o duque e duquesa de Windsor ${ }^{83}$, o prefeito da cidade, Fiorello La Guardia (a quem se refere como "Florzinha", representando um misto de gangster e adulto imbecilizado - ele faz "par" com a imagem ao lado, um bebê; ambos têm o dedo no nariz) e finalmente as brincadeiras das crianças nas ruas do Lower East Side num dia de calor escaldante. A rua fora transformada numa espécie de chafariz ou piscina pública: "escape do calor... os moradores destes tenements abriram o hidrante e se refrescaram. Um guarda chegou e fechou o hidrante... Assim que o 'tira' [cop] se for o hidrante volta a jorrar água de novo"84. O fotógrafo explicita o tema da manipulação e do escapismo no âmbito da indústria cultural, mapeia suas platéias e distingue entre "tipos" de escapistas. O tratamento para a letargia ficará a cargo do próximo capítulo.

"Frankie" já começa com os suspiros e anseios das fãs adolescentes: "Oh, oh, Frankie...". Nas páginas iniciais do capítulo, o texto informa que a fila no Teatro Paramount começa a se formar à meia-noite. Construído em 1926 em Times Square, região que concentra os maiores teatros da Broadway, fora inicialmente concebido para apresentar os sucessos produzidos pela companhia cinematográfica de mesmo nome. Em breve seus três mil e seiscentos assentos serviriam de platéia também para concertos musicais ao vivo, expressão e índice do rápido desenvolvimento da indústria fonográfica no país. Apenas os mais consagrados artistas do segmento se apresentavam no Paramount. Quando Frank Sinatra o fez pela primeira vez em 31 de dezembro de $1942 \mathrm{seu}$ nome já era sinônimo de sucesso. A associação com Tommy Dorsey, uma das

${ }^{82}$ Cf. WEEGEE, Naked City. op. cit. p. 105.

${ }^{83}$ Weegee explica ao leitor a razão pelo retrato do "ex-rei": "Rapidamente tirei seu retrato. Você quer saber por quê? Bem, o Instituto do Charuto Americano quer fotos de celebridades fumando charutos... e oferecem prêmios para os fotógrafos que publicam as fotos nos jornais... Fazem isso para compensar os filmes que mostram os gangsters fumando charuto de lado. Essa foto saiu e ganhei o primeiro prêmio - cinquenta dólares, uma medalha e um bolso cheio de charutos. Depois que tirei a foto, cumprimentei Suas Altezas (sic) e desejei-lhes boa sorte." Cf. WEEGEE, Naked City. op. cit. p. 106.

${ }^{84}$ Cf. WEEGEE, Naked City. op. cit. pp. $110-111$. 
big bands mais importantes da época, permitira-lhe despontar nacionalmente. Quando retornou ao teatro em outubro de 1944, as cerca de trinta e cinco mil fãs que não conseguiram assistir ao show causaram estragos consideráveis nas redondezas por não poderem ver seu ídolo "de perto".

"Lá pelas quatro da madrugada", Weegee continua sua descrição, "já são cerca de quinhentas garotas... elas usam meias curtas [bobby sox ${ }^{85}$ ], é claro, e gravatas borboletas, como as de Frankie; nas roupas trazem grudadas fotos do artista" 86 . A esta fã, cuidadosamente produzida, deu-se o nome de "bobby sock", uma metonímia que tomava o todo por sua parte mais característica (e indispensável para o pertencimento a tal grupo ${ }^{87}$ ), a saber, as meias que viraram moda entre as moças. Um nicho de mercado, as jovens eram o mais recente alvo das gravadoras, que produziam um tipo específico de música popular para uma nova platéia ${ }^{88}$ - até então o público tinha sido composto essencialmente por adultos. Sinatra, possivelmente o primeiro ídolo teen norte-americano, era a mais perfeita expressão desta indústria, além da corporificação do desejo das meninas de classe média baixa que vinham de longe, do Brooklyn e de Long Island $^{89}$, para realizarem seus "sonhos". "Elas trazem seu almoço, sanduíche embrulhado em sacola de papel; para beber o café da garrafa térmica, copos de

\footnotetext{
85 Um "erro" de natureza semelhante àquele cometido na grafia das palavras "reserved" e "latest" em "Murder is my business" é re-introduzido no texto do capítulo. A palavra "meias" em inglês, que deveria ter sido escrita "socks", foi grafada com "x", "sox". O "erro" chama atenção para a palavra, para seu significado diferenciado e para quem a escreveu (a presença de Weegee é de fato ratificada a todo momento no texto e nas imagens do livro). Nos Estados Unidos, a grafia desta palavra com " $x$ " remete imediatamente a certos times de baseball como o famoso Boston Red Sox, o que pode ser indício de um certo tipo de gosto ou hábito popular. Se pensarmos que o "x" é também uma tentativa de aproximação da produção escrita à oral, o "erro" torna-se marca de classe, eco do "malte com petiscos", descritos pelo autor em outro lugar.

${ }^{86}$ Cf. WEEGEE, Naked City. op. cit. p. 112 (meus grifos).

87 Weegee descreve negativamente as fãs de Sinatra como uma "tribo" fechada, utilizando a expressão "clannish bunch", ou seja, um bando com interesses semelhantes que hostilizam todos que não fazem parte do grupo. Cf. WEEGEE, Naked City. op. cit. p. 115.

88 Não é irrelevante notar a distinção entre as carreiras artísticas de Sinatra e alguns de seus contemporâneos, por exemplo, Johnny Hartman. Um cantor negro de baladas, sem o sex appeal que exigia a indústria fonográfica e cinematográfica (Sinatra faria enorme sucesso também em Hollywood), relativamente desconhecido e que circulava essencialmente no universo da música negra norte-americana (gravara com John Coltrane e por algum tempo fora membro da banda de Dizzy Gillespie), Hartman parece ser a antítese do que pretendia ser sua reação branca.

${ }^{89}$ Cf. WEEGEE, Naked City. op. cit. p. 113.
} 
papel"90. A descrição informa também que na fila, quando a luz permite, algumas das garotas lêem revistas especializadas no mundo do showbizz. Para se distraírem, jogam "Old Maid"1 , um jogo de cartas que depende da habilidade do jogador na arte do blefe, ou mostram orgulhosas umas para as outras seus álbuns caseiros, repletos de fotografias do ídolo extraídas dos jornais e revistas (certamente produzidas por fotógrafos como o próprio autor). Weegee aproxima, nas primeiras linhas de seu texto, o que explicitará a seguir em termos fotográficos, a sua própria versão do álbum das garotas que acompanhará o capítulo: trabalho, classe, fragmentação, espetáculo, formas ilusionísticas de representação e modos alternativos para superação do "blefe".

O registro jornalístico impresso à narrativa no primeiro parágrafo sofre um corte abrupto. Como uma câmera que ao terminar a filmagem de uma cena para voltar-se à outra, o texto prossegue, aos saltos, agora nos moldes do inventário. Sem necessidade aparente para o andamento ou desenvolvimento do "enredo", o foco recai sobre a descrição relativamente longa de um conjunto de estatísticas ligadas aos trabalhadores envolvidos na organização do evento: "1 chefe de polícia, 3 capitães, 4 sargentos, 5 policiais femininas, 5 policiais a cavalo, 41 policiais temporários à paisana identificados, 60 policiais, 200 detetives, 2 caminhões de emergência, 20 rádios e um número desconhecido de oficiais à paisana não identificados, além de repórteres, fotógrafos, curiosos, etc." "92 (sem contar o "exército de mensageiros" que trazem o almoço do artista, suas roupas e "até o barbeiro que chega de táxi"93). Para que o mundo do trabalho entre em cena, Weegee precisa interromper a narrativa que avançava "a passos largos" e sonegar os detalhes que aguçam o apetite daquele leitor ávido pelo consumo do fait-divers. Desta narrativa atravancada ausenta-se toda idéia de recompensa, clímax ou êxtase. O repórter-fotográfico redireciona,

\footnotetext{
${ }^{90}$ Cf. WEEGEE, Naked City. op. cit. p. 112.

91 Weegee sugere, com o jogo de palavras "old" e "young" (em "maid", "donzela" em inglês), o apelo sensual ou sexual que o astro exerce sobre as moças casadoiras. "Old maid" significa, literalmente, uma mulher que não conseguiu casar, uma solteirona.

92 Cf. WEEGEE, Naked City. op. cit. pp. $112-113$.

${ }^{93}$ Cf. WEEGEE, Naked City. op. cit. p. 114.
} 
assim, o olhar de seu leitor. Pelas vias da montagem que frustra as expectativas normatizadas do pensamento condicionado por um certo tipo de literatura, imprensa ou fotografia, introduz, com a descrição, um elemento central à obra: a presença de uma coletividade de trabalhadores que trabalha de modo organizado na indústria da notícia e do entretenimento, da qual até o astro é parte integrante. Mesmo com status diferenciado, "Frankie" (a insistência numa grafia em "diminutivo" aproxima a estrela de seus pares) é funcionário (o texto insiste que a turnê do artista é composta por cinco shows completos por dia "full five shows") e deve, portanto, também desempenhar uma tarefa específica no âmbito da indústria do entretenimento. No ensaio fotográfico Weegee repete o teste da câmera ao ator e cantor.

Uma imagem maior à esquerda seguida por duas menores à direita (Figura 26). Na primeira, o astro. Nas outras, sua fã. A sequência, composta quase sempre por planos frontais e repetida quatro vezes, é a estrutura encontrada por Weegee para organizar sua versão do "scrapbook" que as garotas na fila do show de Frankie trazem consigo. A primeira fotografia ocupa quase toda a página e funciona como uma espécie de pôster que anuncia o show que está por começar ${ }^{94}$. A câmera, posicionada em contre-plongé, agiganta ainda mais a figura do artista. Fotografado de perto, o temos quase ao alcance da mão. $O$ retrato em plano aproximado mostra, no centro, parte do aparato técnico que permite a realização do espetáculo, um microfone e seu pedestal. Não podemos deixar de notá-los: imponentes à frente do cantor, demarcam a fronteira entre Sinatra e seu público. O conjunto chama atenção para si por seu tamanho (microfone e suporte ocupam mais de dois terços da imagem), sua cor, negra, e

94 "Numa enorme fotografia ampliada de Sinatra defronte ao teatro as marcas de batom vermelho das fãs, mensagens de amor e até número de telefones". Esta é a definição de Weegee para o cartaz que anuncia o espetáculo do artista no Paramount. Cf. WEEGEE. Naked City. op. cit. p.113. 
seus reflexos brancos (um ponto maior de luz no centro do aparelho, outro menor logo acima e uma linha de luz que percorre toda a haste que o sustenta). Por detrás desta forma fálica, o astro. Paletó negro, camisa, lenço e gravata borboleta brancos. O fundo completamente enegrecido arremessa tanto a cabeça alva de Frankie, ligeiramente para trás e à esquerda, como os acessórios de mesma cor para fora da imagem. O flash de Weegee, o uso de filme infra-vermelho, as possíveis manipulações em laboratório e a reprodução da imagem em papel jornal transformaram o artista numa figura fraturada. Imerso na mesma luz dos objetos a seu redor, foi inserido numa relação de equivalência que sublinha o inorgânico, mínimo denominador comum entre este homem e as coisas a seu redor. Reificado, Sinatra é o baby-face produto da soma de fragmentos. A pele é órgão sem vida, superfície plástica, tecido sintético granulado que enfatiza rugas, reentrâncias e imperfeições, ecoando as dobras de sua gravata. A orelha à direita é a gigantesca forma circular branca, borrão que se cola à máscara evidenciando, pela distinção de cor, a linha fronteiriça entre fragmentos que resistem à formação de um todo. Magnificada pela iluminação (o que se repetirá mais tarde também com outros elementos), essa orelha produz a imagem da conhecida "orelha de abano" e sugere, evidentemente, a figura de um rato. Com o lenço à direita da imagem no bolso de seu paletó forma um díptico: aproximam-se por suas semelhantes texturas, ou, mais precisamente, pela quase total ausência de textura e pela enorme concentração de luz branca, uma luz física, matérica, as maiores áreas deste tipo em toda a fotografia. A orelha à esquerda, por sua vez, não é senão uma sugestão, produto de um corte informado pelo lóbulo que restou. Entreaberta, a boca sorri exibindo um conjunto de dentes desformes e sujos sustentados por uma gengiva manchada. Os dentes são ruídos mais ou menos claros que retinem os pontos de luz do microfone. Fora do ângulo da arcada dentária, está a "nota" que sobressai, o dente à esquerda do lábio superior, mais claro que todos os outros. Ele adentra a superfície interna da boca como que por efeito de choque físico; precariamente grudado, não parece poder resistir na posição por muito tempo. As marcas do que aparece como barba mal-feita sugerem 
desleixo, sujeira ou manchas de decomposição da epiderme. O nariz é um periclitante triângulo duplamente perfurado. Sua sombra negra propõe desunião em mais uma peça na iminência de se descolar da face. Os olhos são cavidades ocas esvaziadas de subjetividade. Caricatura apressada, a sobrancelha à direita é por demais longa; aquela à esquerda muito curta em comparação. Os ossos da testa saltam à vista. São protuberâncias alvas, como hematomas às avessas, hipotéticos resquícios de violência física imputada à figura. Os cabelos de Frankie foram arrancados. Sob a cabeça o enorme casaco que a nega. $O$ tratamento escolhido pelo fotógrafo não poderia ser mais desfavorável à vedete. Trata-se da recusa evidente dos critérios da indústria de celebridades para fotografar ídolos, em vigor até hoje, como se pode observar em qualquer banca de jornais - a abertura do capítulo, assim como a do livro, dá ao leitor/observador todas as regras do "jogo". A perfídia continua: na legenda para a imagem lemos "Sinatra aparece sorrindo". A fã da página seguinte vibra com a aparição do corpo exposto de seu ídolo.

"E uma garota sorri também..." ${ }^{95}$, informa a legenda posicionada entre as duas imagens da mesma fã, que reproduz afoita o movimento do ídolo. Consideravelmente menores que a primeira imagem, as fotografias foram dispostas na página de modo a aproximar suas bases àquela da fotografia do astro (um padrão para todas as quatro sequências), também aproximando fisicamente a garota do leitor. $O$ efeito é ratificado pelo ângulo frontal utilizado em sua representação: uma linha horizontal imaginária aproxima nossos olhares; encontramo-nos tão próximo dela quanto de Sinatra. A proximidade nas imagens do astro e da fã é, todavia, de natureza distinta. Aqui, a câmera posicionada à altura do olho do fotógrafo informa que ao contrário do ídolo nos encontramos no mesmo plano ou posição que sua fã. Nela poderíamos tocar; nele não. É, portanto, deste ponto de vista que o leitor "assistirá" ao show de Frankie.

${ }^{95}$ Cf. WEEGEE. Naked City. op. cit. p.117. 
$\mathrm{Na}$ imagem à esquerda a garota aparece centralizada num espaço exíguo, um pequeno retângulo sufocante e claustrofóbico. Em plano fechado a moça grita histericamente, um grito ecoado pela figura feminina no canto esquerdo superior da imagem, um rosto menor de outra fã dilacerado pela margem superior da fotografia. À esquerda da figura central, um pedaço de ante-braço. À direita, quase fora do quadro, um fragmento de mão e acima, a porção indistinta de outro corpo. A sua frente, o que parece ser uma barra de metal. O movimento de suas mãos, semi-fechadas à altura do rosto, avigora sua excitação. A imagem à direita é quase idêntica a seu par: mais isolada (os corpos a seu redor encontram-se ainda mais fragmentados), a garota aperta as mãos aflita - ou estaria aplaudindo por antecipação? - aguardando pelo início do show que já começara.

Sinatra "canta" sua primeira canção na próxima página (Figura 27). Com alguma variação, por vezes mínima, assistimos à repetição das imagens apresentadas nas quatro sequências padronizadas tanto para o ídolo como para a fã. Nelas, não se modificam os ângulos das tomadas nem tampouco a forma utilizada para os retratos; o flash que invade continua marca constante bem como as outras interferências e manipulações no filme e/ou imagem. Não se trata, porém, do empilhamento de exemplos supérfluos que repisam a validade de um teorema já demonstrado, algo que em teoria "já sabemos". Sinatra será, sim, sempre o corpo ferido e desarticulado exposto em vitrine; a fã, por sua vez, um manequim passivo e oco. Seu cabelo é como a peruca de fibra plástica em cujos reflexos "metálicos" deixados pelo flash de Weegee enxergamos as falsas luzes da tintura caseira de mais uma platinum blonde, sua pele é artificialmente lisa como de uma boneca de porcelana, seus gestos são quase involuntários, determinados externamente, e suas expressões faciais uma espécie de "estampa ilustrativa". Mas é justamente pela monótona repetição e padronização das sequências que Weegee cria um movimento em ascenso para a maior e melhor compreensão do que pretende estudar, a saber, as condições e possibilidades do trabalho na indústria do entretenimento e da notícia e seus 
efeitos sobre o coletivo de seus trabalhadores e sobre seu público. Um tema desta natureza, épico par excellence, encontrará tratamento adequado somente nas formas épicas. Ao contrário das revistas especializadas, não nos interessa aqui a vida particular da celebridade, tampouco a trajetória ou o comportamento individualizado de uma determinada fã. Weegee não faz tablóide como os tablóides nem pretende registrar o fait divers nos termos concebidos pela imprensa tradicional. Ao privilegiar o estudo de relações sociais, o repórter fotográfico recorrerá, assim, ao tratamento das personagens apresentadas como tipos, porque são amostras representativas do coletivo em questão.

Pensemos no uso que faz da tipificação para as fotografias da fã. É insuspeitada a semelhança entre suas expressões faciais no decorrer da série fotografada por Weegee e as fotografias produzidas no século XIX em hospitais e sanatórios mentais que pretendiam descrever e investigar determinados padrões de comportamento ou reações humanas, as supostas patologias que desviavam do que se pensava o modelo de normalidade. Por vezes equipados com laboratórios fotográficos bastante completos, instituições como La Salpêtrière (sob responsabilidade de Charcot) desenvolviam pesquisas que se concentravam tanto na representação fotográfica das variações de traços físicos como olhos, boca, orelha ou nariz como nas descrições das expressões faciais dos pacientes que sugeriam certas emoções, alegria, dor, medo, pânico, tristeza, satisfação ou êxtase, por exemplo. Não era incomum que tais imagens, sobretudo as que pretendiam investigar o desvio nas emoções no comportamento mental dos internos, fossem obtidas a partir de estímulos externos como choques elétricos ou hipnose, induzindo o "modelo" a produzir artificialmente a melhor reação do típico para posterior avaliação médica e científica. As fotografias, organizadas em séries ("bocas", narizes", "expressão de dor", etc.), supostamente auxiliavam as pesquisas rumo à cura das patologias diagnosticadas ${ }^{96}$. Parte dos vários acervos coletados por diferentes instituições médicas foram logo publicados: o Nouveau Traité des Maladies Mentales e a

\footnotetext{
${ }^{96}$ Para as referências iconográficas citadas, ver FRIZOT, M. op. cit.
} 
Iconographie Photographique de la Salpêtrière eram algumas das referências mais conhecidas na época. Os usos deste material não se restringiram, porém, apenas ao meio científico. Com a Comuna de Paris, a polícia francesa utilizaria o uso do princípio médico para identificação, prisão e execução dos communards ${ }^{97}$. As técnicas de catalogação e controle social para evitar tudo o que fosse considerado fora da ordem se provaram eficazes. A partir de 1882 foram aperfeiçoadas a tal ponto pelo criminologista e chefe de polícia parisiense Alphonse Bertillon que sua Descrição Antropométrica seria quase imediatamente adotada por inúmeros países europeus e pelos Estados Unidos, utilizada até $1970^{98}$. As imagens inicialmente concebidas para uso científico tiveram também aproveitamento artístico. Adrien Tournachon (irmão do famoso fotógrafo francês Nadar) usaria o princípio da catalogação para fotografar em 1854 as expressões faciais e corporais do famoso mímico Debureau, artista do Funambules, um teatro no Bulevard do Crime ${ }^{99}$. Na mesma época, o até então pintor e caricaturista Nadar inicia seu trabalho como fotógrafo profissional, produzindo uma fotografia de cunho investigativo - dos retratos de personalidades da época às vistas aéreas da topografia da cidade de Paris.

Acredito que no conjunto de imagens concebidas por Weegee para o capítulo "Frankie", o fotógrafo explicite uma combinação dos usos, até então isolados, para o tipo de fotografia aqui descrita. Será da junção entre os usos médicos, criminalísticos e artísticos que surgirá um produto novo, resultante da refuncionalização das formas conhecidas: os dois primeiros certamente de

${ }_{97}$ Para referências iconográficas e históricas sobre o período, ver BARONNET, J. Regard d'un Parisien sur la Commune - Photographies inédites de la Bibliothèque Historique de la Ville de Paris. Paris: Gallimard, 2006. GODINEAU, L. La commune de Paris par ceux qui l'ont vécue. Paris: Éditions Parigramme, 2010. NOËL, B. GAUTRAND, J. -C. La Commune. Paris: Éditions Nathan, 1998.

98 Para detalhamento sobre o método de identificação de criminosos conhecido popularmente como "bertillonage", ver SEKULA, A. The Body and the Archive. In October n. 39. Boston: MIT Press, 1986.

99 Cf. HAMBOURG, M. M. op. cit. Artisticamente, as fotografias aqui descritas, bem como aquelas produzidas para o capítulo "Frankie", guardam também semelhança insuspeitada com a obra escultórica "proto-expressionista" do alemão Franz Xaver Messerschmidt (1736 - 1783). Para referências às imagens do artista, ver MALIKOVA, M.-P. e SCHERF, G. (ed.). Franz Xaver Messerschmidt - 1736 - 1783 from Neoclassicism to Expressionism. Florença: Conti Pipador Calenzano, 2010. 
conhecimento de um fotógrafo como Weegee; o último, a concepção de formas estéticas a partir dos materiais que se Ihe impunham. Associadas ao caráter investigativo e jornalístico atribuído por Weegee à fotografia, o repórter fotográfico amplia o poder e o escopo da identificação e da descrição (e possível cura?) de patologias e crimes de natureza social e coletiva, um feito possível, insisto, apenas a partir da combinação inédita de forças vetoriais até então isoladas.

Assim, transformadas em ocorrências significativas, marcas de suas posições hierárquicas, sociais e de classe, as personagens serão examinadas em situações comuns mas não de modo comum. Tornadas estranhas em seu próprio habitat, transformam-se em objetos e veículo para escrutínio. A serialização padronizada das imagens e das sequências propostas pelo fotógrafo é, portanto, parte das estratégias e do conjunto de ferramentas utilizadas inclusive para a compreensão da própria serialização e padronização na indústria onde trabalha.

A partir da segunda sequência de imagens, evidencia-se o fato de que o leitor se encontra diante de dois "concertos" que ocorrem "simultaneamente" no teatro Paramount, um de Frankie e outro de Weegee. Guardadas as devidas distinções, ambos começarão em adágio e terminarão em prestíssimo. "Come to me my melancholy baby" é a legenda para Sinatra nesta sequência. Posicionado à esquerda da fotografia, o astro, em plano de $3 / 4$, olha para cima, um negro infinito à direita. O microfone, presente em todas as imagens do cantor, é sempre um elemento visível. Os braços esticados e mãos unidas simulam o abraço e o embalo da fã. Entre juras de amor, o fim das lágrimas com beijos apaixonados e a certeza da superação de quaisquer desentendimentos de ordem amorosa (a letra da canção-legenda da imagem sugere certa desconfiança da amada em relação à suposta infidelidade de seu par romântico), My melancholy baby deixa implícito que: 1 . a voz-sujeito é masculina (não caberia ao homem, sobretudo a um ídolo da estatura de Sinatra, chorar e 
expor suas dores de amor demonstrando sofrimento e fragilidade), 2. há superioridade masculina física e intelectual em relação à mulher (é esta voz que envolve o corpo da amada e discerne entre o que é ou não relevante para a melhor solução do conflito amoroso) e 3. seu "interlocutor" é particularizado (pelo enredo, a voz afiança e exemplifica que gosta mesmo só de uma e pela escolha das palavras, sobretudo do pronome "you", que em inglês poderia também significar marca de plural mas que neste contexto pretende endereçar-se supostamente a uma única pessoa do sexo feminino: "you know, honey, I'm in love with you").

Ainda na mesma sequência, as duas imagens seguintes da fã são praticamente idênticas, não fosse pela omissão da gravata borboleta que a garota não mostra na segunda imagem. O adereço, cópia da cópia, foi cortado por uma linha ascendente que liga os dois fotogramas: a barra metálica que começa na primeira fotografia atravessa hipoteticamente 0 extra-quadro e continua exatamente na mesma posição, altura, espessura e ângulo de inclinação na segunda imagem. A montagem proposta reforça a necessidade de estabelecermos homologias. "Então ela chora", lemos na legenda posicionada entre ambas. Na primeira imagem, os olhos semi-abertos, a sobrancelha franzida e a luz "dura" e "metálica" expressam dor. Na segunda, a mesma cabeça, agora decepada, intensifica a expressão de sofrimento, dividindo o que já era espaço exíguo com o "objeto cortante" que a ferira, o metal acoplado à parcela negra na parte inferior da fotografia.

As outras músicas "cantadas" por Sinatra nas duas últimas sequências, respectivamente Would I love you e I dream of you reforçam a idéia de sedução e amor eterno, contato físico e diálogo entre o homem e seu interlocutor, a mulher amada. "Se pudesse a amaria para sempre", "tomá-la em meus braços é tudo o que desejo mais febrilmente", "sonho com você mais do que você pode sonhar" e "eu a quero tanto, mais do que você pode conceber" são algumas das palavras dirigidas à fã, que crê escutar as juras "secretas" endereçadas única e 
exclusivamente a ela (lembremo-nos que o Teatro Paramount comportava três mil e seiscentas espectadoras sentadas; as milhares que não conseguiram ingresso esperavam do lado de fora pelos relatos sobre o concerto que não viram). Para a terceira sequência Weegee optou por não utilizar como legenda para a fotografia de Sinatra o título original da música que ele "canta", Would I love you, mas uma parte de sua letra, "to take you in my arms", adaptado-a à situação que pretendia retratar. Da intervenção cirúrgica que opera no texto (a citação ou montagem de citações) resulta a legenda "Let Me Take You In My Arms". Ao mesmo tempo que sugere um jogo amoroso de sedução platônica, "deixe-me tomá-la em meus braços" sublinha com sutileza o vigor e pujança do ato físico que culmina com a dominação e a posse definitiva (a letra explica que "tomá-la em meus braços foi sempre meu objetivo, tão certo quanto a lua sobre sua cabeça"; o verbo "to take", em inglês, pode também ser utilizado para descrever a posse, inclusive a amorosa). O suposto diálogo entre o homem e sua amante são reforçados pelo próprio título da canção Would I love you, que na forma invertida do verbo auxiliar sugere simultaneamente a estrutura da pergunta e a ênfase da resposta afirmativa. Outras frases que indicam diálogo incluem "Você me pergunta se eu a amaria se você me deixasse", "Se eu a amaria? Que pergunta, se eu a quero tanto!" e "Como posso provar a você que meu amor é real?". Evidentemente toda a concepção individualizada de diálogo sugerida pelas letras das músicas é ressaltada pelo modo como as canções são encenadas pelo artista - Sinatra "toma" a fã em seus braços e a "embala" com carícias fictícias logo nos primeiros minutos do espetáculo. Tão ilusória quanto a manifestação física de afeto singularizado é a simulação do diálogo.

Já vimos que Weegee fotografou a aparelhagem técnica que permite a enunciação do discurso, o suposto diálogo entre os dois amantes, de modo a salientar sua posição e importância no palco. Nas imagens, o microfone e seu suporte são as marcas da fronteira entre o artista e seu público, o palco e a platéia, no limite um produtor e seus consumidores. A distinção fundamental entre um e outro é, no que diz respeito à aparelhagem técnica, sua posse e 
utilização. E ele é de uso exclusivo do artista. Como Frankie é o único que tem acesso ao microfone, encenando perguntas retóricas para uma platéia de jovens mulheres que não se encontram, sob nenhum aspecto, equipadas para a réplica, o que aparece como diálogo não é senão monólogo disfarçado. Qualquer assimetria entre o astro e suas admiradoras é esfumaçada pela sugestão de sensações táteis (corpóreas) e estados de espírito (ou estados da alma): "venha para mim", "eu a abraçarei", "sorria" e "eu a amo" asseguram à amada despreocupação, alegria extrema, êxtase gozoso e sonho finalmente realizado. Sensações descritas, nesta ordem, pelas imagens propostas por Weegee para as quatro sequências que descrevem o show de Sinatra: a fã sorri, chora, e atinge o êxtase, realizando seu sonho de ouvir o cantor "de perto".

E nada obstante, as músicas cantadas por Sinatra parecem jingles publicitários que não anunciam senão o próprio cantor. Tanto nas letras como na mise-enscène a vedete implora o amor da menina de subúrbio (o registro proposto por Weegee não deixa quaisquer dúvidas de que não é realista!), promete fidelidade e garante satisfação, ou, se preferirmos, busca instaurar uma atmosfera que promete satisfação plena (satisfação garantida!) numa relação de fidelização entre as partes, falaciosa desde o início uma vez que o enredo já explicitara que o objeto do desejo não é propriamente "fiel". Ora, não é esta a forma como a mercadoria corteja e se relaciona com seus possíveis clientes? "Se pudesse a amaria para sempre", "tomá-la em meus braços é tudo o que desejo mais febrilmente", "sonho com você mais do que você pode sonhar" e "eu a quero tanto, mais do que você pode conceber" adquirem então significação para além do trivialmente compreensível. Por detrás do corpo brutalizado do cantor, engajado em esforço físico para executar seu trabalho, mantendo enquanto pode seus fragmentos unidos - não foi assim que Weegee o representou? revela-se o típico: a própria essência da mercadoria. É este o objeto do desejo exposto em vitrine que a platéia pagou para adorar. Noutros termos, antes de adorar Sinatra a fã, numa relação fetichizada adora (adorar) a mercadoria representada na/pela força de trabalho que Frankie vende no mercado - ele 
deve fazer cinco shows por dia, já lemos no texto do capítulo. Sua música não passa, portanto, de um jingle que anuncia uma mercadoria, o corpo capaz de satisfazer o constante e insaciável desejo da platéia ávida por experiências de segunda ordem, vividas por procuração.

Entretanto, não é isso que vê a fã ao assistir o show da estrela. A mise-en-scène concebida para o concerto de Sinatra no teatro obscurece não apenas as estruturas espetaculares que ocultam toda assimetria entre elas (no plural!) e o ídolo mas também os modos de visão que possibilitem o aclaramento das relações fetichizadas que têm lugar no âmbito da indústria cultural. Inversamente, na montagem fílmica articulada por Weegee para descrever 0 evento que presenciara, o leitor-espectador do "concerto paralelo" supera as limitações impostas pelos modos tradicionais de representação. É pelas vias dos meios reprodutíveis e pela justaposição de planos característicos da montagem cinematográfica que o repórter fotográfico supera e avança em relação à cena que acontece no teatro, expondo o engano e o confisco da iniciativa do espectador que a cena teatral não revela. $E$ o faz: 1. pela refuncionalização de parte do repertório técnico-expressivo oriundo do cinema clássico hollywoodiano, mais especificamente a montagem que sugere a ideia de diálogo na forma campo/contra campo (tradicional modo de representação de diálogo), 2. pela exposição, em termos fotográficos, da ausência de encontro entre o olhar de Frankie e o de sua fã, 3. pela encenação de cenas dialogadas que não são diálogos, 4. pela identificação dos espectadores do concerto teatral com as emoções fictícias da personagem principal, sem qualquer tentativa de elevá-las ao nível da reflexão, 5. pela insistência na montagem que chama atenção para si, em cada uma das fotografias e no conjunto formado por todas elas, insistindo numa construção que revela um ponto de vista externo àquele construído no interior do campo ou do fotograma (vale lembrar que a um só tempo assistimos ao concerto de Sinatra do ponto de vista da fã e a apresentação fotográfica ou "cinematográfica" de Weegee do ponto de vista do trabalhador da indústria da notícia). O capítulo explicita, assim, dois níveis de representação: o primeiro, 
essencialmente dramático, o segundo, de natureza épica, construído com recursos fílmicos destinados ao olhar do leitor de Naked City. Em suma, das possibilidades oferecidas pelo enquadramento e montagem resulta a introdução de outro ponto de vista, superior àquele do narrador interno à cena. Ao separálos, Weegee expõe o artifício como tal, servindo-se da própria forma fetichizada. No primeiro modo de exposição, há tão somente o reforço das camadas de ilusão. No segundo, o fotógrafo parte dela para construir estratégias que segmentam os elementos constitutivos do objeto sob sua lente para sua exposição numa demonstração argumentada. Ao mostrá-lo nestes termos, apresenta ao leitor uma nova pedagogia da percepção, ou seja, um novo significado para a o ato de ver ao mesmo tempo que sugere as consequências (nefastas) da incapacidade de desenvolvê-lo nos termos propostos.

$\mathrm{Na}$ terceira sequência, a fã desmaia ao som de Let me take you in my arms (Figura 28). Na primeira imagem, ainda ereta, esboça os últimos movimentos com as mãos, elevadas à altura da face. Na segunda, desfalece. $\mathrm{O}$ tom da pele mais escuro que em qualquer outra de suas imagens no capítulo, o cabelo sem - mesmo brilho e a cabeça inclinada para um lado revelam uma figura abandonada. Já sem vigor, findaram-se seus movimentos e cessaram suas funções vitais. Experimentara ao paroxismo a intensidade de uma sensação. $O$ sono da razão produziu os monstros que saíram do capítulo "Murder" para ilustrar "Frankie". O grotesco é explicitado pela legenda, "The Swoon". O termo, de uso literário, arcaico ou humorístico, pode ser traduzido por êxtase, desmaio ou desfalecimento (no sentido de definhar) e normalmente se refere, na língua inglesa, a um comportamento feminino. No concerto de Sinatra, a fã é levada à morte pelo clímax físico que the proporciona o prazer do contato com o inorgânico na vitrine bem como por sua incapacidade de ver nos termos sugeridos por Weegee. Nas fotografias, o êxtase religioso que cultua a mercadoria é transformado em material para análise de processos sociais da vida cotidiana. O sofrimento (o crime) aparentemente privado é na verdade público e coletivo. Esta Santa Teresa do Brooklyn, artificialmente exagerada 
como aquela de Bernini, não se pretende, ao contrário da obra do mestre do barroco italiano, um instrumento de propaganda do culto de massa ou mecanismo de retórica. Nas palavras de Argan:

"[n]ão espantava que, dirigindo-se ao divino, o discurso fosse bastante exaltado, hiperbólico, adulatório, limitado somente pelas capacidades da técnica do discurso ou pela operação artística. A técnica devia ser capaz de simular o milagre, aliás ela era o meio humano com que o divino miraculosamente se revelava: a extraordinária técnica do Bernini escultor e arquiteto repetia os movimentos da retórica aristotélica, ora demonstrativa, ora insultante, ora tonitruante. Uma técnica vigorosamente persuasiva, cujo objeto de persuasão não era certamente o conteúdo doutrinal da representação, mas sim o complexo movimento da alma, com sua alternância de evidências palmares e subentendidos, de trepidações e saltos. Todas as técnicas berninianas podem ser explicitadas como recitação, e isto explica a centralidade do teatro no quadro de sua complexa poética - que, definitivamente, é uma grande dramaturgia. [...] A grande novidade de Bernini é justamente a pura visualidade, a capacidade de a imaginação artística preencher a consciência sem dar espaço à reflexão e ao juízo."100

É precisamente pelo uso hiperbólico das formas disponíveis de representação, agora refuncionalizadas, que Weegee refuta a pura visualidade, rechaça a dramatização da morte (a fã morre com vulgaridade semelhante à existência que levara até então - pensemos novamente em Manet, que representa um toureiro morto ou um aspargo da mesma maneira) e preenche a consciência com

\footnotetext{
100 Cf. ARGAN, G. C. Bernini e Roma. In Imagem e persuasão - ensaios sobre o barroco. São
} Paulo: Companhia das Letras, 2004, pp. 430 - 431 (meus grifos). 
reflexão e juízo. As hipérboles alucinatórias desmascaram o absurdo de uma lógica ao revelarem, num universo tão real quanto fantástico ou, se preferirmos, tão fantasticamente real, a lógica deste absurdo.

$\mathrm{Na}$ última sequência, a fã-consumidora "ressuscita" (Figura 29): "êxtase e exaustão", informa a legenda. Sem consciência do processo pelo qual passara, é uma e todas (a última imagem da quarta sequência ratifica a idéia de um coletivo ao incluir novamente no campo visual outro rosto de mulher). Multiplicada, renasce para repetição ad infinitum do mesmo ciclo - "às duas da manhã o teatro fecha... os funcionários chegam para a limpeza... algumas das garotas ficaram ali todo o dia e toda a noite e mesmo tendo visto os cinco shows recusam-se a sair, tentando esconder-se nos banheiros femininos... mas as funcionárias as põem para fora... [...] então elas saem e entram na fila novamente...."101. Ao comportamento nada realista (porque pautado inteiramente pela indústria cultural) cabe a atribuição de estruturas e formas que assim o revelam. Ausente toda subjetividade da consumidora siderada de estesias, tem lugar um acúmulo de clichês forjados no âmbito da padronização, serialização, e naturalização do que de fato não é nada natural. Personagem oca, a violência do espetáculo confiscara da fã suas possibilidades de ação consciente, provando-se a representação da mais pura violência. Ao propor para ela uma montagem que remete à estrutura do sonho (no decorrer do livro, os cadáveres se transmutam no tempo e espaço até adquirir as formas de um Sinatra ou suas admiradoras chegando, no final de Naked City, a tomar a forma do fotógrafo Alfred Stieglitz, como vimos, um dos maiores representantes do pictorialismo norte-americano), Weegee explode novamente o conceito engessado de realismo. Este não acomoda ou permite, por exemplo, espelhamentos invertidos, deslocamentos, aproximações insuspeitadas, seleção e re-ordenação de fragmentos, utilização de gêneros variados ou a estruturação episódica, avigorando, enfim, todas aquelas características do receituário prescrito pelas convenções dramáticas que impossibilitam qualquer tentativa que almeje, pela

${ }^{101}$ Cf. WEEGEE. Naked City. op. cit. p.114. 
fidelidade à essência do material analisado (a experiência psíquica/de classe dos tipos em questão), a exposição do "business of dreams" que é a indústria do entretenimento. É tão somente pela ruptura que o fotógrafo cria as devidas condições para as pressuposições de mediações que, uma vez elaboradas pelo leitor, auxiliarão na compreensão da realidade por trás da realidade aparente. A fã renascida em duplicata na última imagem do capítulo é a antítese do leitor que Weegee pretende atingir ${ }^{102}$. Ela, objeto sem alma entre objetos sem alma, é índice de uma metástase desejada com a anuência da platéia, por ela personificada; a primeira fotografia da admiradora na primeira sequência do capítulo informa que ela sorri. Ao fim e ao cabo, na agitação explosiva e no delírio ofegante de todas as sequências seguintes, a figura expressa menos um sorriso que a mais veemente das expressões orais, o grito. $O$ desenho sonoro deste ruído desforme e mudo (pensemos em Munch) é (re)articulado para a recepção diferenciada do leitor, que aqui identifica a verossimilhança do monstruoso. E quem seria, afinal, este leitor, público alvo de Naked City?

Sem excluir outros possíveis interessados, o último capítulo do livro aponta para o público ao qual todo o material se destina, os foto-jornalistas atuantes na indústria da notícia, os veteranos, mas sobretudo os novatos e aqueles que pretendem iniciar na profissão, ou seja, os trabalhadores que ainda não dominam a técnica, que desconhecem as regras, condições e possibilidades de trabalho no campo e que, portanto, necessitam de um guia (a palavra "beginner" aparece por duas vezes em destaque). O capítulo, composto unicamente de texto (é o maior em extensão que qualquer outro na obra), revela ao leitor o passo a passo necessário para sobreviver no mercado com chances de sucesso, desvenda as técnicas básicas e o equipamento fotográfico essencial, dá dicas de como começar e insiste em que este é um métier que se aprende como outro qualquer. Weegee entrega ao leitor de "Camera Tips" o que promete

\footnotetext{
102 Num período não muito distante do lançamento de Naked City, Tennessee Williams daria, no teatro, notícia de processos análogos ao descrever o comportamento de uma fã em relação a seus ídolos, forjados no seio da indústria cultural. A esse respeito ver a peça Camino Real. In WILLIAMS, T. The Rose Tatoo and Other Plays. Londres: Penguin Books, 1976.
} 
seu título: as primeiras dicas que motivarão o uso consciente e consequente da câmera que não se restringe ao caráter estático da fotografia e que almeja de fato desnudar 0 assunto escolhido.

Logo no primeiro parágrafo o fotógrafo lista o equipamento necessário a um fotojornalista, o tipo de câmera, as lentes, o filme fotográfico, o flash e seu sincronizador. Menciona também as aberturas do diafragma e as velocidades do obturador que utiliza para garantir a qualidade nas imagens produzidas sob condições adversas ou em situações que não oferecem margem para o erro. Inicia, portanto, a listagem não apenas dos materiais necessários para a produção das fotografias mas como estes devem ser utilizados para a garantia da máxima legibilidade da cena, a centralidade do tema sem ambiguidades, ambivalências ou indecisões (e opiniões!) que poderiam impedir a execução de uma fotografia comercializável. De início e sem floreio, deixa claro que as dicas que seguirão se inserem todas no âmbito da produção comercial (e não Artística), revelando informações que a vasta maioria dos profissionais do ramo (até hoje) preferem sonegar, sobretudo pelo enorme receio que têm da concorrência.

Como garantir o foco na imagem (os editores, explica, só compram fotografias com foco perfeito), a importância e necessidade de legendas explicativas que as acompanhem (Weegee relata sua experiência no PM Daily, seu receio inicial de escrever e a superação dos obstáculos para produzir as informações complementares fundamentais para a publicação das matérias) e como começar na profissão sem idealização ou mistificação do aparelho tecnológico, da técnica ou do próprio ofício ("não tenho tempo para acessórios desnecessários porque toda minha energia está concentrada no evento que tem lugar diante dos meus olhos"103) são outras considerações valiosas para um novato na profissão. Didático, o fotógrafo explica o porquê de uma determinada câmera e não outra, a importância da prática constante fora das horas de atividade profissional

${ }^{103}$ Cf. WEEGEE. Naked City. op. cit. p.240. 
("pratique em casa... você não terá tempo quando estiver cobrindo uma matéria"104) e a relevância das decisões informadas no ato de fotografar ("pense antes de fotografar"105). Mas por onde começar? Weegee reconforta os mais novos, sugerindo o contato com jornais, revistas e agências, fornecendo endereços ("Acme News Pictures fica no número 461 da oitava avenida em Nova York"106), recomendando os tamanhos mais adequados das cópias a serem enviadas aos editores bem como o papel fotográfico a ser utilizado, informando os preços praticados no mercado (para que o novato não seja ludibriado no início de sua carreira) e a política de direitos autorais. A necessidade de conceber a profissão como parte integrante de uma rede de trabalhadores que devem, imperiosamente, desenvolver um esprit de corps não foi absolutamente negligenciada. Weegee menciona o rádio doméstico como um instrumento útil para coleta de informações, o corpo policial como uma fonte de informações preciosas, a possibilidade de instalação de um rádio policial no carro do aspirante a foto-jornalista no decorrer de suas atividades (desmistificando, assim, sua suposta para-normalidade), a possibilidade de conseguir credenciais de fotógrafo da imprensa junto aos jornais ou revistas em futuros trabalhos e a consideração que deve ter o profissional com outros trabalhadores que permitem a realização de suas tarefas, por exemplo os policiais ou bombeiros que burlam certas leis para se distraírem durante 0 horário de trabalho: "os tiras e os bombeiros às vezes gostam de fumar um cigarrinho às escondidas durante $\mathrm{o}$ trabalho, mas se a câmera os pega em flagrante eles terão que responder por seus atos [they will be brought to charges]. Quando for tirar uma foto e vir que estão fumando, peça para largarem o cigarro... eles o agradecerão pela sua consideração"107.

104 Cf. WEEGEE. Naked City. op. cit. p.239.

105 Cf. WEEGEE. Naked City. op. cit. p.241.

${ }^{106}$ Cf. WEEGEE. Naked City. op. cit. p.242.

${ }^{107}$ Cf. WEEGEE. Naked City. op. cit. p.241. 
O capítulo termina insistindo na importância do caráter modelar de outras produções. Weegee ratifica que para vender uma imagem e sobreviver no mercado o profissional sério, como ele, deve, antes, observar seu entorno.

"Você deverá abordar a questão de como melhor vender seu trabalho estudando os jornais e revistas para ver como outros fotógrafos lidam com uma matéria específica. Pense como você a cobriria. Lembre-se... o campo é vasto e está aberto. Seja original e desenvolva um estilo próprio, mas acima de tudo e todos não se esqueça... seja humano... pense... sinta. Quando você começa a sentir uma ligação entre si mesmo e as pessoas que fotografa, quando você ri e chora com seus risos ou lágrimas, você saberá que está no caminho certo. Boa sorte!"108

A idéia expansionista da formação de quadros e a tentativa de ampliação do número de "Weegees" se faz evidente em Naked City. O livro provou-se, é certo, um catálogo ampliado da exposição "Murder is my business", mas o business de Weegee não exclui a produção de um manual que almeja incrementar o número de profissionais semelhantes - não espanta o sucesso imediato da obra: afinal o fotógrafo falava com milhares como ele! O uso do imperativo se encontra por todo o texto do capítulo: faça, vá, pense, fotografe. Mas a prescrição não é jamais reducionista, estética, artística ou politicamente. As dicas propostas ao longo do capítulo e do livro, que deverá agora ser relido sob o ponto de vista daquele que inicia seu trabalho como fotógrafo na indústria da produção de notícias, sugerem que o profissional competente não abasteça o aparelho de produção, sem o modificar, tanto quanto possível, num sentido socialista ${ }^{109}$. Aqueles que exercem seu ofício ou arte sob a influência de uma corporação de artesãos que trabalham com materiais e procedimentos fetichizados,

${ }^{108}$ Cf. WEEGEE. Naked City. op. cit. p.243.

${ }^{109}$ A formulação é de Walter Benjamin no ensaio O autor como produtor. Cf. BENJAMIN, W. op. cit. 
protegendo-os contra toda tentativa racional de compreendê-los ou rearticulá-los não passam de auteurs que conservam sua inspiração e pseudo-liberdade no âmbito da produção artesanal, individual e fetichizada, feudo de uma aristocracia estética que é também política (Pictorialismo).

\begin{abstract}
"A massa de fotógrafos amadores, os milhares de repórteres e de correspondentes, a despeito de sua mediocridade e ausência de qualificação, são produtores em potencial. Devese dar-lhes a devida qualificação. São mais preciosos para uma autêntica socialização da arte que qualquer mestre altamente qualificado." 110
\end{abstract}

No decorrer de Naked City, Weegee nega veementemente todo solipsismo, apontando para a relevância da função coletiva e de intervenção da obra no contexto de sua produção - para isto disponibilizara o material no seio da mesma indústria que não raro censura produções similares; seu gesto é sobretudo uma intervenção política no domínio da esfera pública. Aqui, a especialização do trabalhador adquire novos significados. Agora um generalista, este profissional deverá ser capaz de reunir, selecionar e organizar a matéria prima para executar sua obra no âmbito de uma prática coletiva e relevante, dentro das relações sociais de produção de sua época. O caso de Weegee é paradigmático pois sua formação, avanços e conquistas literárias, artísticas e políticas somente fazem sentido se pensadas inclusive como fruto das experiências que fomentava um meio que havia ultrapassado todas as forças solitárias no âmbito da produção, o jornal. É Sergei Tretiakov quem dá a chave para a compreensão desta questão.

"Somente o trabalho coletivo ligado à uma especialização interna dá ao jornal a possibilidade de sua existência. Mas o

110 Cf. TRÉTIAKOV, S. À Suivre. In Dans le front gauche de l'art. Paris: François Maspero, 1977, p. 109. 
traço coletivo do trabalho literário não é unicamente característico dos jornais e revistas. Ele penetra também os livros. O fato de uma 'obra de arte' levar habitualmente apenas o nome de seu 'criador' não é senão uma falsificação. O livro é produto de inúmeras mãos e é apenas por hábito que a mão do mestre compositor dissimula aquela dos outros. Cada garoto fotógrafo é um soldado do combate contra os academicismos do cavalete e cada pequeno repórter objetivista tem na ponta de sua pluma a morte das belas letras." $" 111$

Cronista do fait divers, Weegee não apenas explicitou formalmente em Naked City as mãos e vozes que contribuíram para a empreitada do que compreendera ser uma encomenda social (o livro é dedicado "a vocês, as pessoas de Nova York"), mas apostou suas fichas na expansão da rede de trabalhadores que, como ele, diminuiriam a distância entre produtores e consumidores. Ao fotojornalista iniciante ficam seus votos de boa sorte e o modelo para operar a síntese que cria generalizações e reduz estruturalmente os fatos à sua essência, para, a partir daí, informar na obra o ritmo geral da sociedade pelo ponto de vista privilegiado de um de seus setores ${ }^{112}$.

\footnotetext{
"Além da oportunidade de dar todo tipo de entrevista e trabalhar para revistas chiques, pode-se dizer que Naked City fez outra coisa por mim - criou um 'novo Weegee'”113. Subitamente o fotógrafo tornou-se in. Guiava personalidades e socialites pelo sub-mundo de Nova York em sua ronda noturna, concedia

111 Cf. TRÉTIAKOV, S. À Suivre. op. cit. pp. $105-106$.

112 A formulação é de Antonio Candido. Cf. Dialética da malandragem. In CANDIDO, A. 0 discurso e a cidade. São Paulo: Duas Cidades, 1993.

${ }^{113}$ Cf. WEEGEE. Weegee by Weegee. op. cit. p. 93.
} 
entrevistas a jornalistas de prestígio, circulava pelos museus mais importantes e flertava com Hollywood. Comprados o título e os direitos de seu uso, Naked City virou filme dirigido por Jules Dassin (a versão que chegou às telas era 0 documento da dilapidação feita pela imposição das exigências mercadológicas dos produtores e executivos responsáveis), no qual Weegee fora contratado como assistente de fotografia e ator (seu nome não aparece nos créditos em nenhuma das funções desempenhadas; como ator, representou a si mesmo numa brevíssima cena de perícia policial). Em 1947 abandona a fotografia freelance e deixa Nova York para tentar carreira em Hollywood. Na cidade, fez o que pôde para ver sua estrela continuar a reluzir: começara como consultor de fotografia, fazendo o que chamou de "trick photography", truques de fotografia que causavam determinados efeitos visuais. Também contratou um agente e virou ator. Um fotógrafo policial, um suspeito de assassinato no remake do clássico europeu $M$, de Fritz Lang e um vagabundo incluíam algumas das personagens que o artista representava na tela - não chegavam a ser nem mesmo personagens secundárias no enredo. A palavra "rápida" não descreve suas aparições em cena: em The Set Up (filme de 1949 de Robert Wise) Weegee representa o funcionário da arena de boxe responsável por soar 0 gongo que anuncia o início e término das lutas. Em sua primeira aparição, de costas e inidentificável, permanece na tela por três segundos. Na última, de frente e com menos sorte, apenas um (seu nome tampouco consta nos créditos do filme). Não ficou na cidade por muito tempo.

De volta a Nova York, fez todo tipo de trabalho que percebia condizente com sua condição de aspirante a vedete full time: fotografou para Vogue, ofereceu consultoria para programas de televisão, retratou celebridades e rainhas do teatro burlesco, vendeu conselhos para revistas especializadas em fotografia como Photo, Photographer's Showcase e Art Photography, veículos que primavam pela publicação de pin-ups de seios fartos e fez ensaios "artísticos" para revistas como House of 1,000 girls, cujo nome dá pistas concretas sobre o conteúdo da publicação. Com lentes especiais que causavam sensação 
caleidoscópica, incrementou os efeitos visuais que realizara para os filmes de Hollywood transformando a técnica fotográfica desenvolvida durante seus anos formativos de foto-jornalista em truques que destorciam a fisionomia dos célebres retratados (Marilyn Monroe é uma das imagens mais famosas do período). A estas caricaturas deu o título de Arte, que pretendeu, no status de vendedor ambulante de grife prêt-à-porter, comercializar entre os museus que ainda reconheciam seu nome. O modelo era, evidentemente, Picasso, a quem considerava o monarca soberano da arte moderna que reinava absoluto nas paredes do MoMA.

Weegee era um ignorante em História da Arte (achava que suas fotografias para os jornais tinham um quê de Rembrandt - nada mais distante!), mas sobretudo desconhecia a fração política que a conduzia, influenciava e não raro a determinava (a ênfase recai mais na palavra "História" que em "Arte", no sentido esteticista que comumente lhe é atribuído). A operação mercadológica póssegunda Guerra Mundial que cultivava internamente nos Estados Unidos o American way of life e externamente a tentativa de ramificações da indústria cultural com, no campo das artes, a apropriação do conceito de arte moderna e seu deslocamento de Paris para Nova York se encontrava em curso, contava com estratégias de Estado e precisava de uma arte autóctone, que excluiria a fração mais politizada da vanguarda francesa (o Cubismo de Braque e Picasso ou a energia revolucionária do Surrealismo de Breton e Aragon). A aproximação do que percebia ser "Picasso", ou seja, sua interpretação muito particular (e incomensuravelmente equivocada!) da obra do artista espanhol, fora uma aposta errada e a manobra comercial não surtira os frutos desejados. Weegee não seria o darling da fotografia moderna numa "guinada" que tampouco pode ser lida como um movimento exclusivamente de caráter individual ${ }^{114}$.

\footnotetext{
114 Não cabe aqui desenvolver e expandir todas as implicações da complexa questão que foi a apropriação e consolidação do conceito de arte moderna nos Estados Unidos. A este respeito, sugiro a leitura da crítica de Mário Pedrosa sobre a obra de Jackson Pollock e a pesquisa de dois intelectuais que mapearam a extensão do processo em suas vertentes artísticas, literárias, políticas, intelectuais e críticas. A este respeito, ver: ARANTES, O. (org). Modernidade Cá e Lá - Textos Escolhidos IV Mário Pedrosa. São Paulo: EDUSP, 2000. GUILBAUT, S. How New
} 
Mas Weegee revela-se um exemplo paradigmático até mesmo em sua tentativa amalucada e arrière-garde pós-Naked City de autotransformar-se no Auteur que toma emprestado as conquistas da vanguarda européia fazendo uso localizado e cosmético de procedimentos formais desenraizados de seu chão histórico, chamando a isso de sofisticação formal. Em seu caso, como o engano não é bem fundamentado nas aparências, o processo é flagrante. Pelas novas lentes, o fotógrafo revela, sem o vigor dos raios e trovoadas, os primeiros capítulos da tempestade que estaria por vir: talentos individuais que pretendiam com o rótulo de "radical chique" apenas a inserção parasitária num sistema de comercialização das artes, o apagamento dos traços do trabalho coletivo, o desmembramento (ou assassinato) de formas artísticas e a transformação de crenças políticas em excentricidades estéticas.

E no entanto, nada disso invalida a lição cifrada em Naked City. A base material do papel político da memória que é reconstruída no livro é exemplar da estratégia de resistência constante, organizada e coletiva contra a repressão, padronização e modernização dos modos e métodos de trabalho sobre os quais se assenta o livro, determinantes do tipo de existência descrita em suas fotografias. Seu conjunto caleidoscópico compõe a imagem maior de um processo ao mesmo tempo em formação e em dissolução, buscando fazer a anatomia (ou a arqueologia) deste mesmo processo no seio do aparato cultural no qual se insere. Ao estruturar esteticamente as formas sociais que encontra a seu redor (ou seja, formas que criam formas), o livro rechaça todo meio-termo ou juste-milieu e oferece, nestes termos, maior inteligibilidade tanto ao real quanto ao fictício.

Em Naked City, o raio de luz do flash de Weegee é um aviso de incêndio. Contra a consolidação do perigo, a iluminação relâmpago. E uma que nos lembra, com

York Stole the Idea of Modern Art - Abstract Expressionism, Freedom, and the Cold War. Chicago e Londres: The University of Chicago Press, 1983. GUILBAUT, S. Voir, ne pas voir, faut voir - essais sur la perception et la non-perception des œuvres. Nimes: Éditions Jacqueline Chambon, 1993. TERES, H. Renewing the Left - Politics, Imagination, and The New York Intellectuals. Nova York e Oxford: Oxford University Press, 1996. 
a necessária dose de teimosia para a convocação à ação consciente que disputa uma memória em permanente construção, que forças enfraquecidas não significam forças extintas. 


\section{EPÍLOGO:}

Outros capítulos

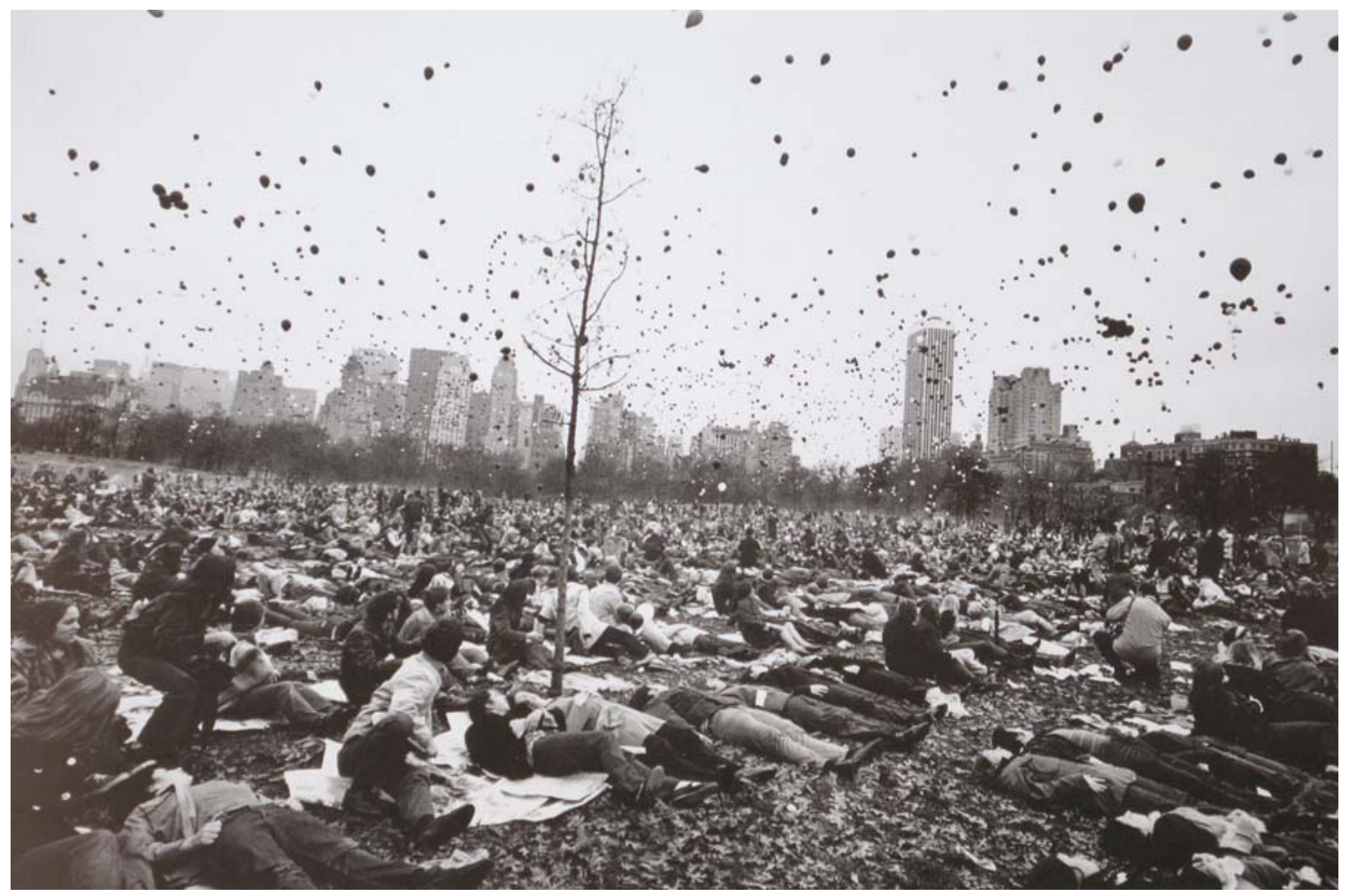

Garry Winogrand, Passeata pela paz [Peace demonstration, Central Park, New York], 1970. 


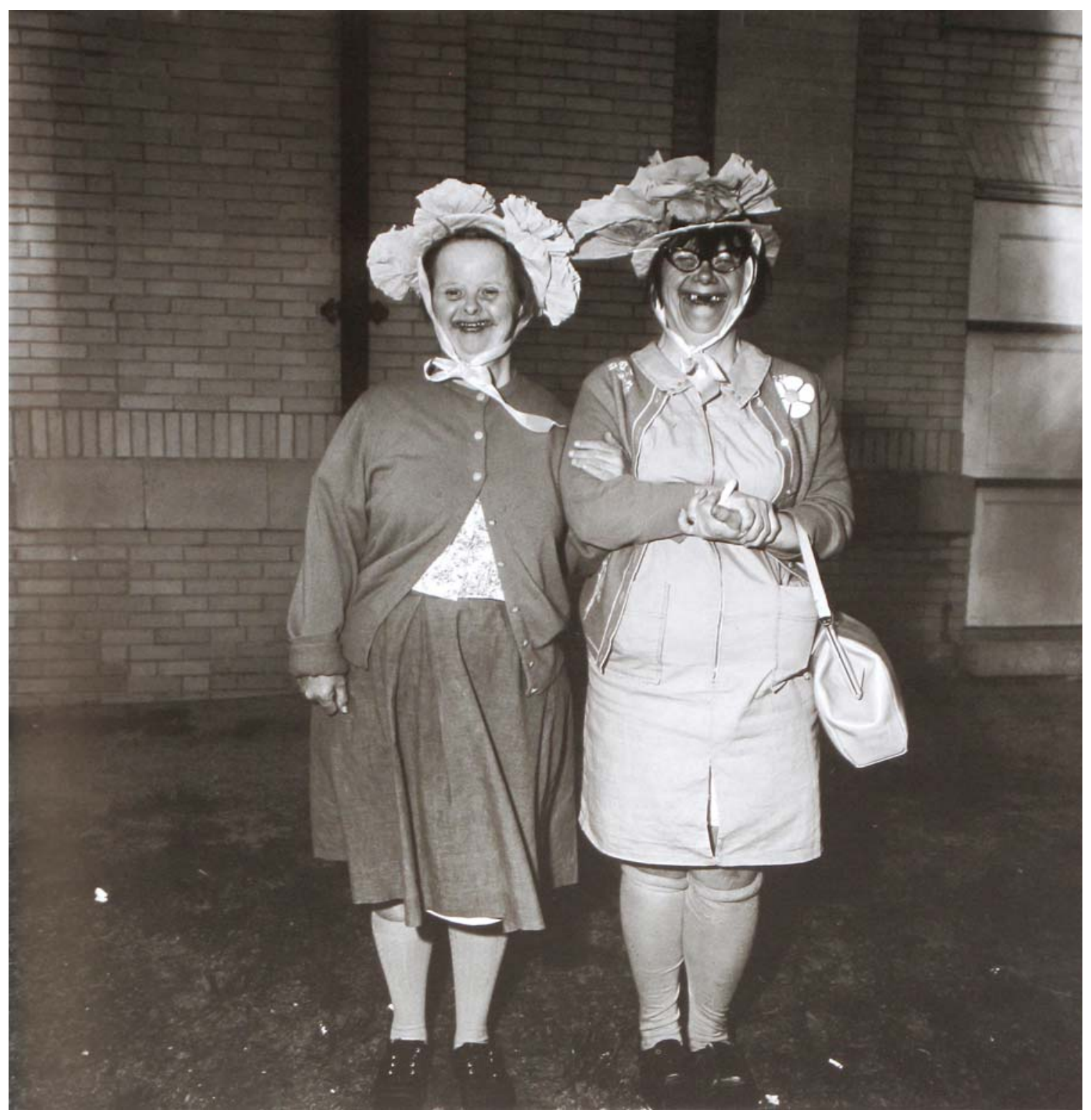

Diane Arbus, Sem título (I) [Untitled (I)], 1970 - 71. 


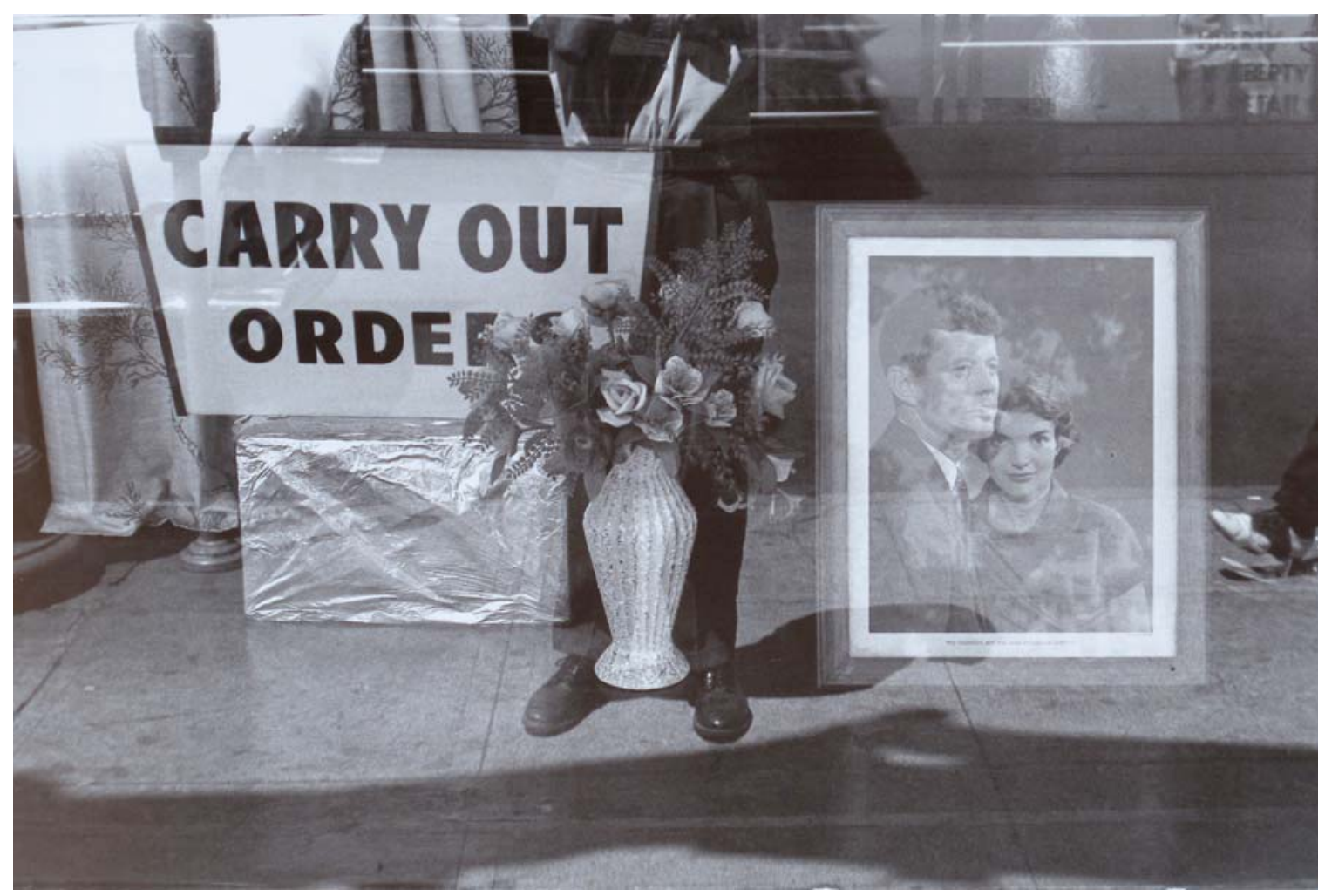

Lee Friedlander, Washington, D.C., 1962. 


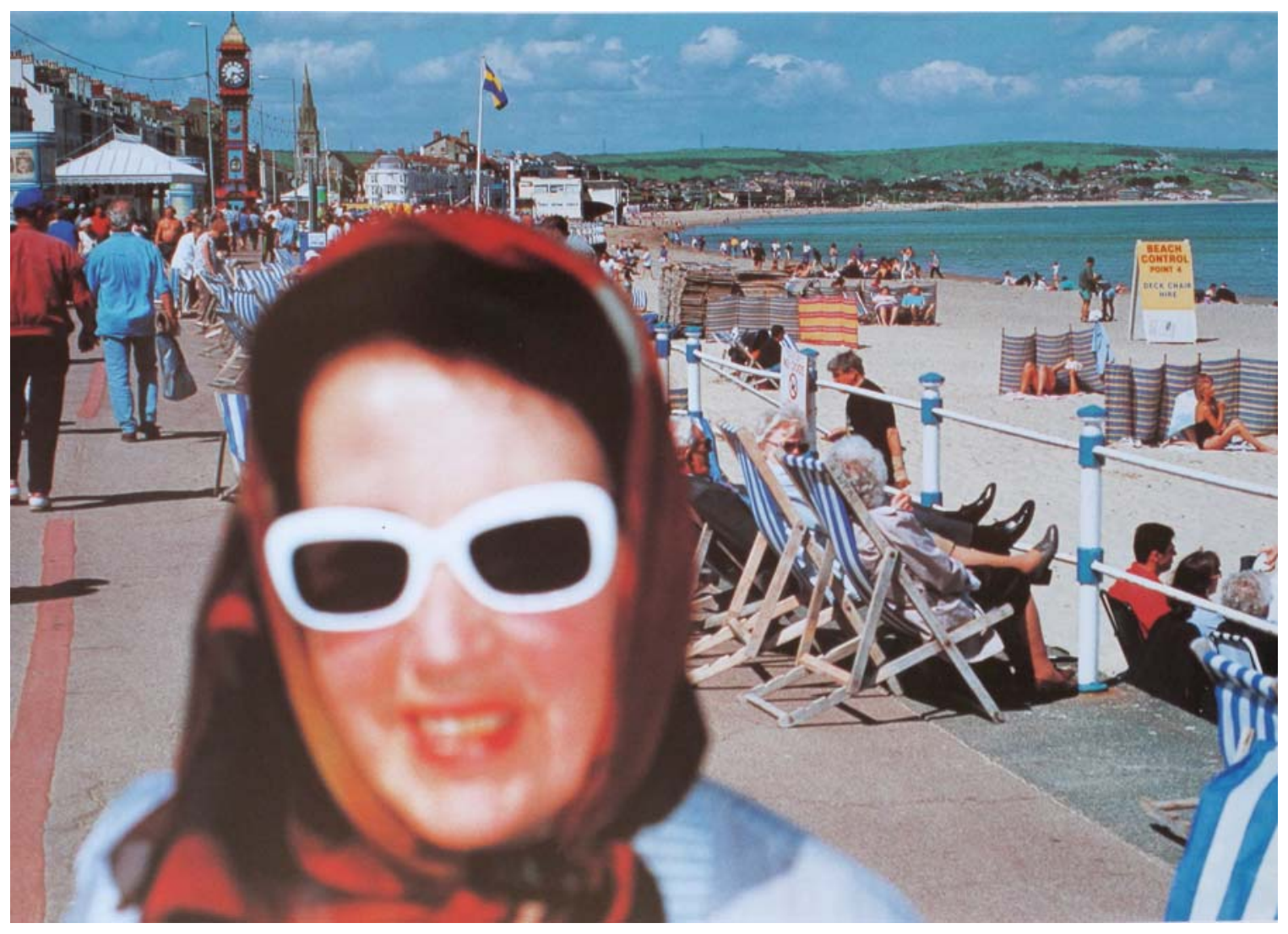

Martin Parr, Weymouth, Dorset, 1996 - 2000. 


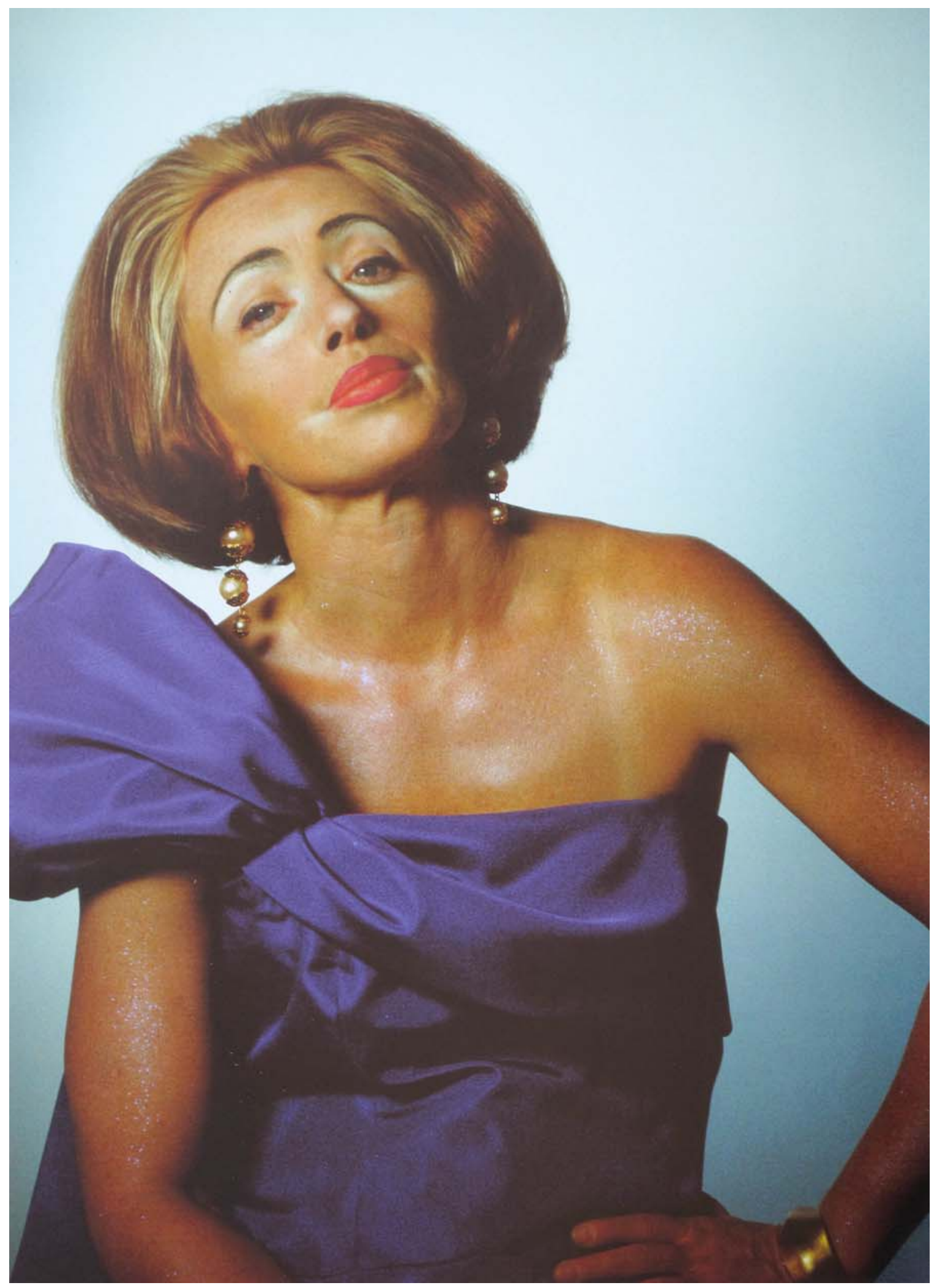

Cindy Sherman, Sem título \# 400 [Untitled \# 400 Hollywoods / Hampton Types], 2000 


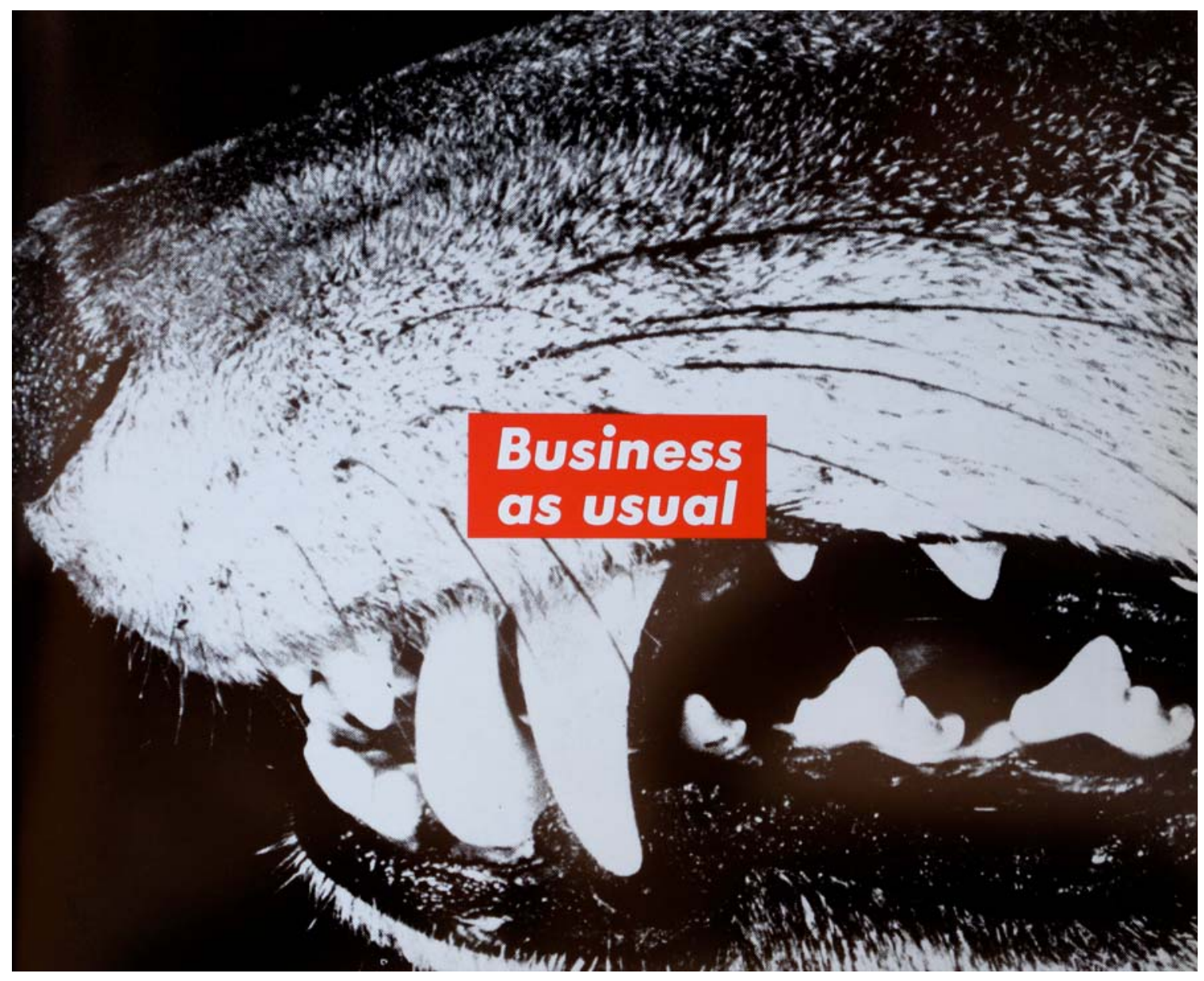

Barbara Kruger, Sem título [Untitled - Business as usual], 1987. 


\section{Bibliografia}

ADORNO, T. W. Prisms. Cambridge, Massachusetts: The MIT press, 1994.

ADORNO, T. e HORKHEIMER, M. Dialectic of Enlightenment. Londres e Nova York: Verso, 1995.

ARANTES, O. (org). Modernidade Cá e Lá - Textos Escolhidos IV Mário Pedrosa. São Paulo: EDUSP, 2000.

ARANTES, P. (org.). Sérgio Ferro - arquitetura e trabalho livre. São Paulo: Cosac Naify, 2006.

ARBUS, D. Diane Arbus - An Aperture Monograph. Nova York: Aperture Foundation, Inc., 1997.

ARGAN, G. C. História da arte italiana - volume II de Giotto a Leonardo. São Paulo: Cosac \& Naify, 2003.

Arte Moderna - do iluminismo aos movimentos contemporâneos.

São Paulo: Companhia das Letras, 2004.

. Imagem e persuasão - ensaios sobre o barroco. São Paulo: Companhia das Letras, 2004.

A arte moderna na Europa - de Hogarth a Picasso. São Paulo: Companhia das Letras, 2010.

AUBernas, S. e ROUBERT, P-L. Primitifs de la Photographie - Le calotype en France 1843 - 1860. Paris: Gallimard / Bibliothèque Nationale de France, 2010.

BAETJER, K. (ed.). Watteau, Music, and Theatrer. Nova York: The Metropolitan Museum of Art, 2009. 
BAKHTIN, M. Rabelais e Gógol (Arte do discurso e cultura cômica popular). In Questões de literatura e de estética - a teoria do romance. São Paulo: UNESP, 1993.

BANDEIRA DE MELLO, M. T. Arte e fotografia - o movimento pictorialista no Brasil. Rio de Janeiro: Funarte, 1998.

BARONNET, J. Regard d'un Parisien sur la Commune - Photographies inédites de la Bibliothèque Historique de la Ville de Paris. Paris: Gallimard, 2006.

BARTH, M. Weegee's World. Nova York: Bulfinch Press Book, 1997.

BAUDELAIRE, C. CEuvres complètes. Paris: Éditions Robert Laffont, 1980. As flores do Mal [tradução, introdução e notas de Ivan Junqueira]. Rio de Janeiro: Nova Fronteira, 1985. . Au-delà du Romantisme - Écrits sur l'art. Paris: Flammarion, 1998. . Poesia e prosa. Rio de Janeiro: Editora Nova Aguilar S. A. 2006.

BEAUMONT-MAILLET, L. Atget Paris. Paris: Hazan, 1992.

BERGER, J. Ways of Seeing. Londres: British Broadcasting Corporation \& Penguin Books, 1972. About Looking. Nova York: Vintage International, 1991.

BENJAMIN, W. Obras escolhidas - magia e técnica, arte e politica. São Paulo: Brasiliense, 1993.

. Obras escolhidas III - Charles Baudelaire, um lírico no auge do capitalismo. São Paulo: Editora Brasiliense, 1994. 
BOISSON, M. Charles Gille ou le chansonnier pendu (1820 - 1856) Histoire de la gogette. Paris: J. Peyronnet \& Compagnie, Éditeurs, 1925.

BOYER, M. C. Dreaming the Rational City - The Myth of American City Planning. Cambridge, Massachusetts: The MIT Press, 1983.

BRESSON, H. -C. The Mind's Eye - Writings on Photography and Photographers. Millerton, NY: Aperture, 1999.

BROWN, J., BANNER, L. A., SCHULZ, A. e WOLF, R. The Spanish Manner Drawings from Ribera to Goya. Nova York: The Frick Collection / Scala Publishers, 2010.

BUCK-MORSS, S. The Dialectics of Seeing - Walter Benjamin and the Arcades Project. Cambridge, Massachusetts: The MIT Press, 1991.

BUISINE, A. Eugène Atget ou la mélancolie en photographie. Nimes: Éditions Jacqueline Chambon, 1994.

BULLOCK, M. e JENNINGS, M. (ed.). Walter Benjamin - Selected Writings Volume 1 - 1913 - 1926. Cambridge, Massachusetts: The Belknap Press of Harvard University Press, 1996.

BURCH, N. Práxis do cinema. São Paulo: Perspectiva, 2006.

CACHIN, F. Manet - “J'ai fait ce que j'ai vu”. Paris: Découvertes Gallimard et Réunion des Musées Nationaux, 1994.

CANDIDO, A. O discurso e a cidade. São Paulo: Livraria Duas Cidades, 1993. 
Catálogo da exposição L'école de Barbizon - Peindre en plein air avant l'impressionisme. Lyon: Musée des Beaux-Arts, 2002.

Catálogo da exposição Camille Pissarro - Impressions of City \& Country. New Haven e Londres: Yale University Press, 2007.

Catálogo da exposição Cindy Sherman. Paris: Éditions Flammarion / Éditions Jeu de paume, 2006.

Catálogo da exposição Gustave Courbet. Paris: Éditions de la Réunion des musées nationaux, 2007.

Catálogo da exposição La Volupté du Goût - La Peinture Française au Temps de Madame de Pompadour. Paris: Somogy éditions d'art, 2008.

Catálogo da exposição Lee Friedlander. Sevilha: IVAM, 1992.

Catálogo da exposição The Spirit of Barbizon - France and America. São Francisco: The Museum Association of America, 1996.

Catálogo da exposição Van Gogh and the colours of the night. Nova York: The Museum of Modern Art, 2008.

CEVASCO, M. E. e OHATA, M. (org.) Um crítico na periferia do capitalismo: reflexões sobre a obra de Roberto Schwarz. São Paulo: Companhia das Letras, 2007.

CLARK, T. J. Image of the People - Gustave Courbet and the 1848 Revolution. Berkeley e Los Angeles: University of California Press, 1999. . The Absolute Bourgeois - Artists and Politics in France 1848 1851. Berkeley, Los Angeles e Londres: University of Califórnia Press, 1999. 
A pintura da vida moderna - Paris na arte de Manet e de seus seguidores. São Paulo: Companhia das Letras, 2004.

. The Painting of Modern Life. In FRASCINA, F. e HARRIS, J. Art in Modern Cuture - an Anthology of Critical Texts. Nova York: Phaidon Press Limited \& Open University, 2006,

- Será que Benjamin devia ter lido Marx? In CLARK, T. J. Modernismos (org. Sonia Salzstein). São Paulo: Cosac Naify, 2007.

COOK, D. A. A History of Narrative Film. Londres e Nova York: W. W. Norton \& Company, 1996.

COSTA, H. e SILVA, R. R. A fotografia moderna no Brasil. São Paulo: Cosac Naify, 2004.

DAGARRON, É. [et alii]. L'ABCdaire de Manet. Paris: Flammarion, 1998.

DANIEL, M. [et alii]. Edgard Degas photographe. Paris: Bibliothèque National de France, 1999.

DANIEL, M. Stieglitz, Steichen, Strand - Masterworks from the Metropolitan Museum of Art. Nova York: The Metropolitan Museum of Art / Yale University Press, 2010.

DEBORD, G. La Société du Spectacle. Paris: Gallimard, 1992.

DENNING, M. The Cultural Front - The Laboring of American Culture in the Twentieth Century. Londres e Nova York: Verso, 1997.

Dictionnaire Mondial de la Photographie - des origines à nos jours. Paris: Larousse, 1994.

DIDEROT, D. Salons. Paris: Éditions Gallimard, 2008. 
DIXMIER, M. [et alii]. Quand le crayon attaque - images satiriques et opinion publique en France 1814 - 1918. Paris: Éditions Autrement, 2007.

EDEY, M. e SULLIVAN, C. Great Photographic Essays from Life. Boston: New York Graphic Society, 1978.

FABRIS, A. (org.). Fotografia - usos e funções no século XIX. São Paulo: EDUSP, 1998.

FELLIG, A. Weegee by Weegee - an autobiography. Nova York: Ziff-Davis Publishing Company, 1961.

FONSMARK, A. -B. [et alii]. Gustave Caillebotte. Ostfildern: Hatje Cantz Verlag, 2008.

FRANCASTEL, P. Histoire de la peinture française. Paris: Éditions Denoël, 1990.

FRASCINA, F. [et alii]. Modernidade e modernismo - a pintura francesa no século XIX. São Paulo: Cosac \& Naify Edições, 1998.

FRIZOT, M. A New History of Photography. Colônia: Könemann Verlagsgesellschaft $\mathrm{mnH}, 1998$.

GAUTRAND, J. -C. La Commune. Paris: Éditions Nathan, 1998.

GODINEAU, L. La commune de Paris par ceux qui l'ont vécue. Paris: Éditions Parigramme, 2010 
GUILBAUT, S. How New York Stole the Idea of Modern Art - Abstract Expressionism, Freedom, and the Cold War. Chicago e Londres: The University of Chicago Press, 1983.

. Voir, ne pas voir, faut voir - essais sur la perception et la nonperception des œuvres. Nimes: Éditions Jacqueline Chambon, 1993.

GOMBRICH, E. H. A História da Arte. Rio de Janeiro: Editora Guanabara Koogan, 1993.

GRANDVILLE, J. J. Vie Privée et Publique Des Animaux. Paris: J. Hetzel, Librarie-Éditeur, 1868.

. Les Metamorphoses du Jour. Paris: Garnier Frères LibrariesÉditeurs, 1869.

HAMBOURG, M. M. [et alii]. Nadar. Nova York: The Metropolitan Museum of Art, 1995.

HARRIS, D. Eugène Atget - Itinéraires parisiens. Paris: Musées et Éditions du Patrimoine, 1999.

HARVEY, D. Paris, Capital of Modernity. Nova York e Londres: Routledge, 2006. . The Right to the City. In New Left Review n. 53, Second Series, September - October, 2008.

HAUPTMAN, J. Georges Seurat - The Drawings. Nova York: The Museum of Modern Art, 2007.

HAUSER, A. História social da arte e da literatura. São Paulo: Martins Fontes, 1995. 
HERBERT, R. L. From Millet to Léger - Essays in Social Art History. New Haven e Londres: Yale University Press, 2002.

JENKINS, H. What Made Pistachio Nuts? - Early Sound Comedy and the Vaudeville Aesthetic. Nova York: Columbia University Press, 1992.

KELLER, J. In Focus Weegee - Photographs from The J. Paul Getty Museum. Los Angeles: The J. Paul Getty Museum, 2005.

KRUGER, B. Love for sale - the words and pictures of Barbara Kruger. Nova York: Harry N. Abrams, Inc., 1996.

LEE, A. e MEYER, R. Weegee and Naked City. Berkeley: University of California Press, 2008.

LE GALL, G. Atget - Life in Paris. Paris : Éditions Hazan, 1998.

LeMAGNY, J.-C. e ROUILLÉ, A. (ed.). Histoire de la Photographie. Paris: Larousse, 1998.

LEROY, J. Atget - magicien du vieux Paris. Joinville le Point: Pierre Jean Balbo Éditeur, 1975.

LÉVÊQUE, J.-J. Honoré Daumier. Paris: ACR Édition, 1999.

LÖVY, M. Walter Benjamin: aviso de incêndio - uma leitura das teses "Sobre o conceito de história". São Paulo: Boitempo Editorial, 2005.

A cidade, lugar estratégico do enfrentamento das classes insurreições, barricadas e haussmannização de Paris nas Passagens de Walter Benjamin. In Margem Esquerda - ensaios marxistas n. 8. São Paulo: Boitempo Editorial, Novembro de 2006. 
LUKÁCS, G. Problèmes du réalisme. Paris: L’Arche, 1975.

LAVIN, M. [et alii]. Montage and Modern Life 1919 - 1942. Boston: The MIT Press, Cambridge, Massachusetts, 1992.

MALIKOVA, M.-P. e SCHERF, G. (ed.). Franz Xaver Messerschmidt - 1736 1783 from Neoclassicism to Expressionism. Florença: Conti Pipador Calenzano, 2010.

MANCEUVRE, L. Jean-François Millet - Pastels et dessins. Paris: Bibliothèque de l'image, 2002.

MARTINS, L. C. Manet - uma mulher de negócios, um almoço no parque e um bar. Rio de Janeiro: Jorge Zahar Editor, 2007.

. O hemiciclo: imagem da forma-Nação. In Crítica Marxista. São Paulo: Fundação Editora UNESP, 2009, n. 29.

. Pintura e trabalho: trabalho intelectual e trabalho corporal na pintura de Cézanne, Van Gogh e predecessores. Texto não publicado.

MARX, K. Les luttes de classes en France. Paris: Éditions Gallimard, 1994. O 18 Brumário. São Paulo: Paz e Terra, 2002.

MARX, K. e ENGELS, F. Manifesto comunista. São Paulo: Boitempo Editorial, 1998.

MERRIMAN, J. M. The Margins of City Life - Exporations on the French Urban Frontier, from 1815 - 1851. Nova York e Oxford: Oxford University Press, 1991.

MATOS, O. Discretas esperanças - reflexões filosóficas sobre o mundo contemporâneo. São Paulo: Nova Alexandria, 2006. 
MICHEL, L. La Commune - Histoire et souvenirs. Paris: La Découverte \& Syros, 1999.

MICHEL, R. e SAHUT, M. -C. David - L'art et le politique. Paris: Découvertes Gallimard et Réunion des Musées Nationaux, 2003. . Bara: du martyr à l'éphèbe. In La Mort de Bara - de l'événement au mythe. Autour du tableau de Jacques-Louis David. Avignon: Fondation du Muséum Calvet, 1989.

MILKMAN, P. PM - A New Deal in Journalism, 1940 - 1948. New Brunswick, New Jersey: Rutgers University Press, 1997.

MONCAN, P. Le Paris d'Haussmann. Paris: Les Éditions du Mecène, 2009.

NESBIT, M. Atget's Seven Albuns. New Haven e Londres, Yale University Press, 1992.

NESBIT, M. e REYNAUD, F. Intérieurs Parisiens - Eugène Atget. Paris: Éditions Carré/Paris-Musées, 1992.

NOCHLIN, L. Courbet. Nova York: Thames \& Hudson, 2007. . Realism. Londres: Penguin Books, 1990.

OEHLER, D. O Velho Mundo Desce aos Infernos. Auto-Análise da Modernidade Após o Trauma de Junho de 1848 em Paris. São Paulo: Companhia das Letras, 1999. . Terrenos vulcânicos. São Paulo: Cosacnaify, 2004.

ORVELL, M. After the Machine - Visual Arts and the Erasing of Cultural Boundaries. Jackson: University Press of Mississippi, 1995. 
PICHOIS, C. Baudelaire et Constantin Guys. In Constantin Guys - Fleurs du Mal. Paris: Éditions des musées de la Ville de Paris, 2002.

POIVERT, M. Les relations internationales du pictorialisme au tournant du siècle (1898 - 1902). In Le Salon de Photographie - Les écoles pictorialistes en Europe et aux Etats-Unis vers 1900. Paris: Musée Rodin, 1993.

POSTMAN, N. Amusing ourselves to death - public discourse in the age of showbusiness. Nova York: Penguin Books, 2005.

RECHT, C. Eugène Atget Lichtbilder. Munique: Rogner \& Bernhard GmbH \& Co. Verlags KB, 1975.

ROSENBLUN, N. A World History of Photography. Nova York, Londres, Paris: Abbeville Press Publishers, 1997.

ROSENFELD, A. Cinema: arte e indústria. São Paulo: Editora Perspectiva, 2002.

ROUBERT, P. - L. L'image sans qualités - Les beaux-arts et la critique à l'épreuve de la photographie 1839 - 1859. Paris: Monum / Éditions de patrimoine, 2006.

ROUX, N. e GILBERT, F. Jean-François Millet - Voyages en Auvergne et Bourbonnais - 1866 - 1868. Clermont-Ferrant: Skira / Seuil, 2002.

SALÉ, M. -P. Dessins de Jean-François Millet. Paris: Musée d'Orsay, 2006.

SANTE, L. Low Life - Lures and Snares of Old New York. Nova York: Farrar, Strauss and Giroux, 1991. 
SCHIFFRIN, A. Dr. Seuss \& Co. Go To War - The World War II Editorial Cartoons of American's Leading Comic Artists. Nova York: The New Press, 2009.

SCHLESSER, T. e TILLIER, B. Courbet face à la caricature - Le chahut par l'image. Paris: Éditions Kimé, 2007.

SCHWARZ, R. Ao vencedor as batatas. São Paulo: Livraria Duas Cidades, 1988.

Que horas são? São Paulo: Companhia das Letras, 1989.

. Seqüências brasileiras - ensaios. São Paulo: Companhia das Letras, 1999.

- Entrevista a GONÇALVES, A. e CARIELLO, R. Desapareceu a perspectiva de um progresso que torne o pais decente. Folha de São Paulo. llustrada, pp. E 8 - 9, Sábado, 11 de Agosto de 2007.

SHIFF, R. Cézanne and the End of Impressionism - A Study of the Theory, Tecnique, and Critical Evaluation of Modern Art. Chicago e Londres: The University of Chicago Press, 1986.

SEKULA, A. The Body and the Archive. In October n. 39. Boston: MIT Press, 1986.

SIMMEL, G. The Philosophy of Money. Londres: Routledge and Kegan Paul Ltd., 2003.

STETTER, L. Weegee. Nova York: Alfred A. Knopf, 1977.

TARABOUKINE, N. Le dernier tableau - du chevalet à la machine - pour une théorie de la peinture. Écrits sur l'art et l'histoire de l'art à l'époque du 
constructivisme russe, présentés par Andrei Nakov. Paris: Éditions Champ Libre, 1980.

TERES, H. Renewing the Left - Politics, Imagination, and The New York Intellectuals. Nova York e Oxford: Oxford University Press, 1996.

THÉZY, M. Marville Paris. Paris: Hazan, 1994.

TINTEROW, G. e LACAMBRE, G. Manet / Velázquez - The French Taste for Spanish Painting. Nova York: The Metropolitan Museum of Art, 2003.

TRACHTENBERG, A. (ed) Classic essays on photography. New Haven: Leete's Island Books, 1980.

TRÉTIAKOV, S. Dans le front gauche de l'art. Paris: François Maspero, 1977.

VALÉRY, P. Degas Danse Dessin. Poitiers: Gallimard, 2003.

WEEGEE. Naked City. Nova York: Da Capo Press, 1973.

WILLET, J. (org.) Brecht on theatre - the development of an aesthetic. Londres: Methuen, 1978.

WILLIAMS, T. The Rose Tatoo and Other Plays. Londres: Penguin Books, 1976.

WILLIAMS, V. Martin Parr. Londres: Phaidon Press Limited, 2002.

WINOGRAND, G. Public Relations. Nova York: The Museum of Modern Art, 2004.

WISMANN, H. (org.). Walter Benjamin et Paris. Paris: Éditions du Cerf, 2007. 
ZOLA, É. Le bon combat - de Courbet aux Impressionistes. Paris: Hermann, 1974. . Écrits sur l'art. Paris: Gallimard, 1991. . L’Assommoir. Paris: PML, 1995.

ZOLA, E. F. Zola Photographer. Nova York: Seaver Books, 1988. 


\section{Anexos}

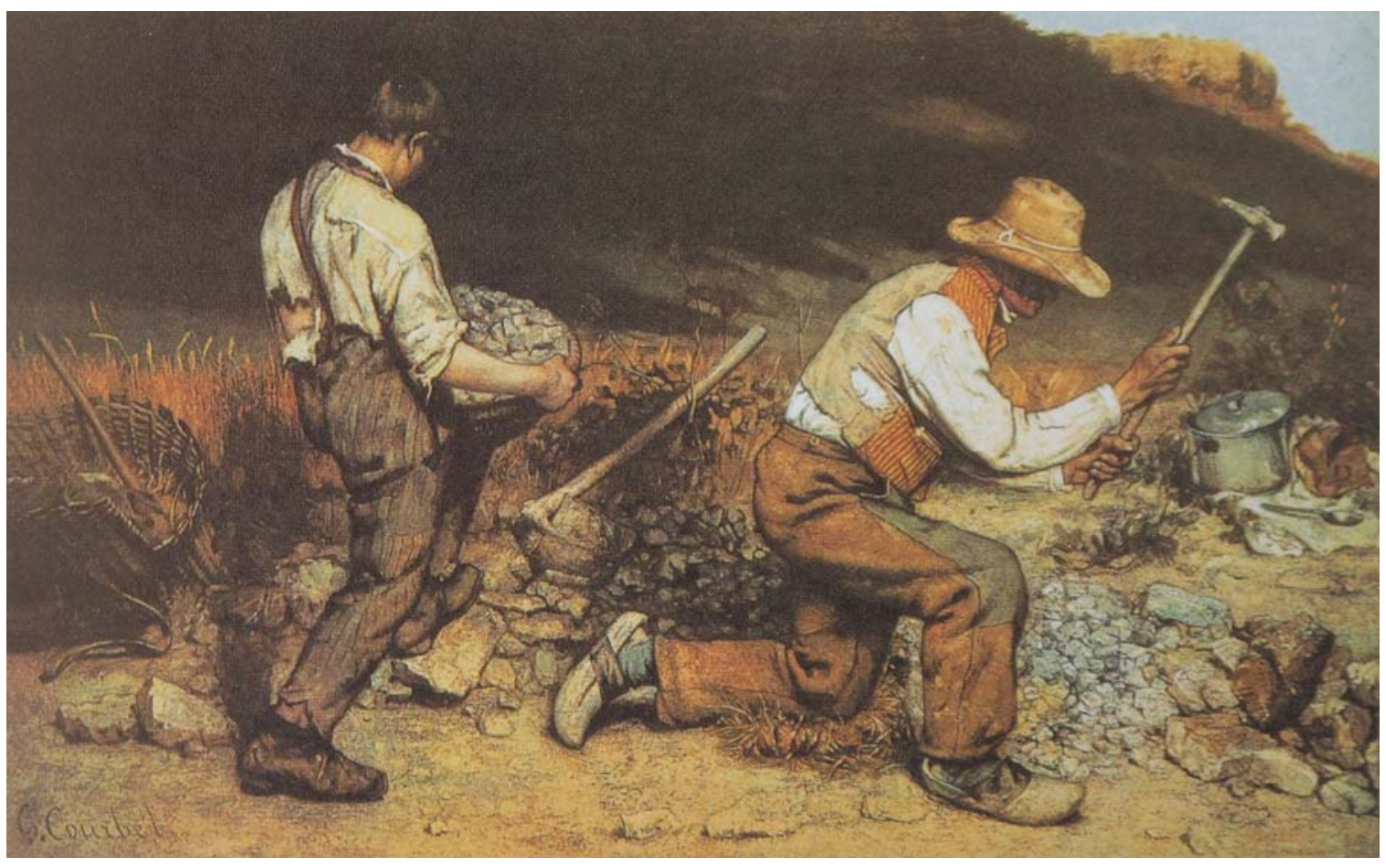

Figura 1: Gustave Courbet, Os quebradores de pedra, 1849 - 50 (tela destruída). 


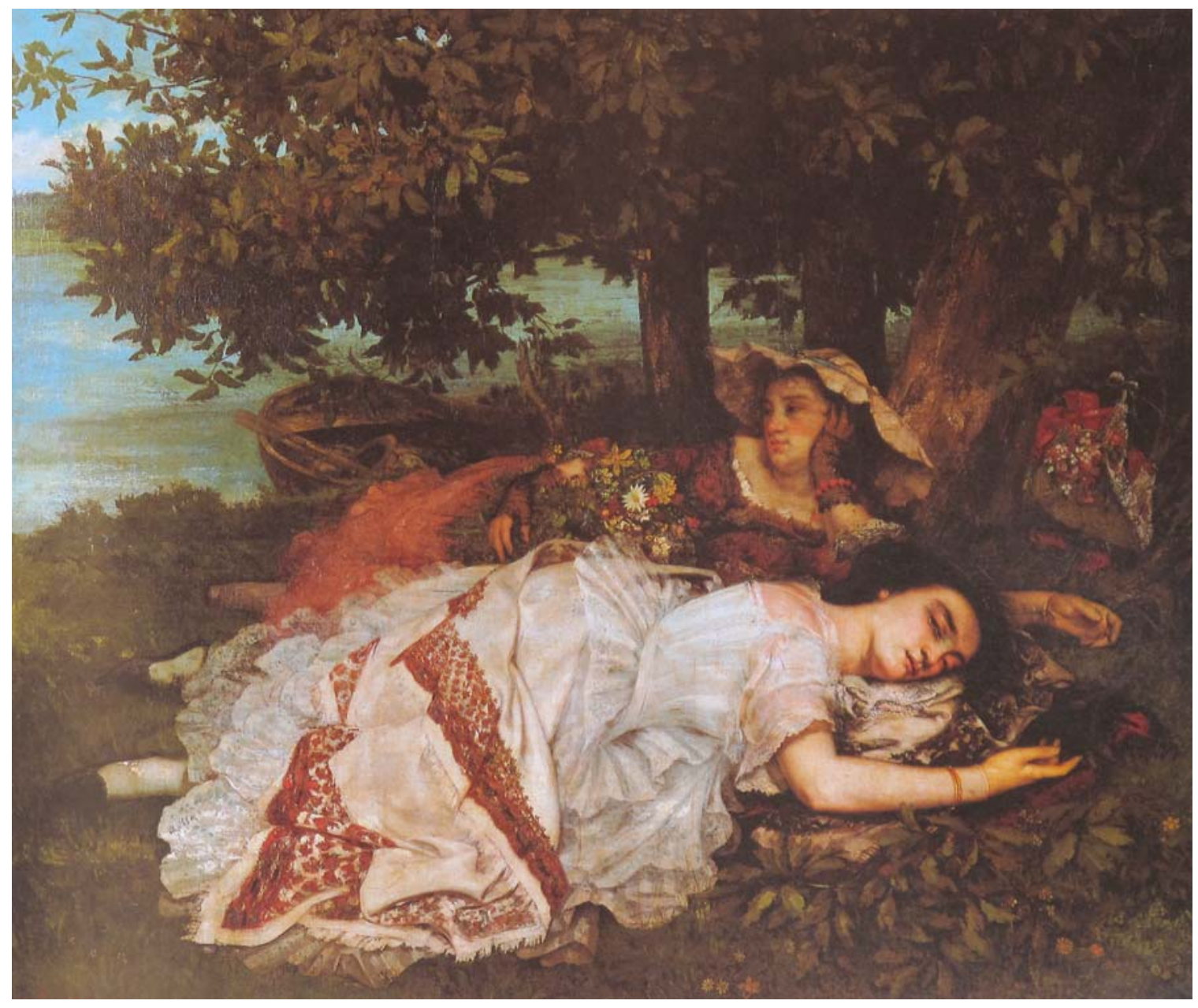

Figura 2: Gustave Courbet, Moças à margem do Sena, 1857. 


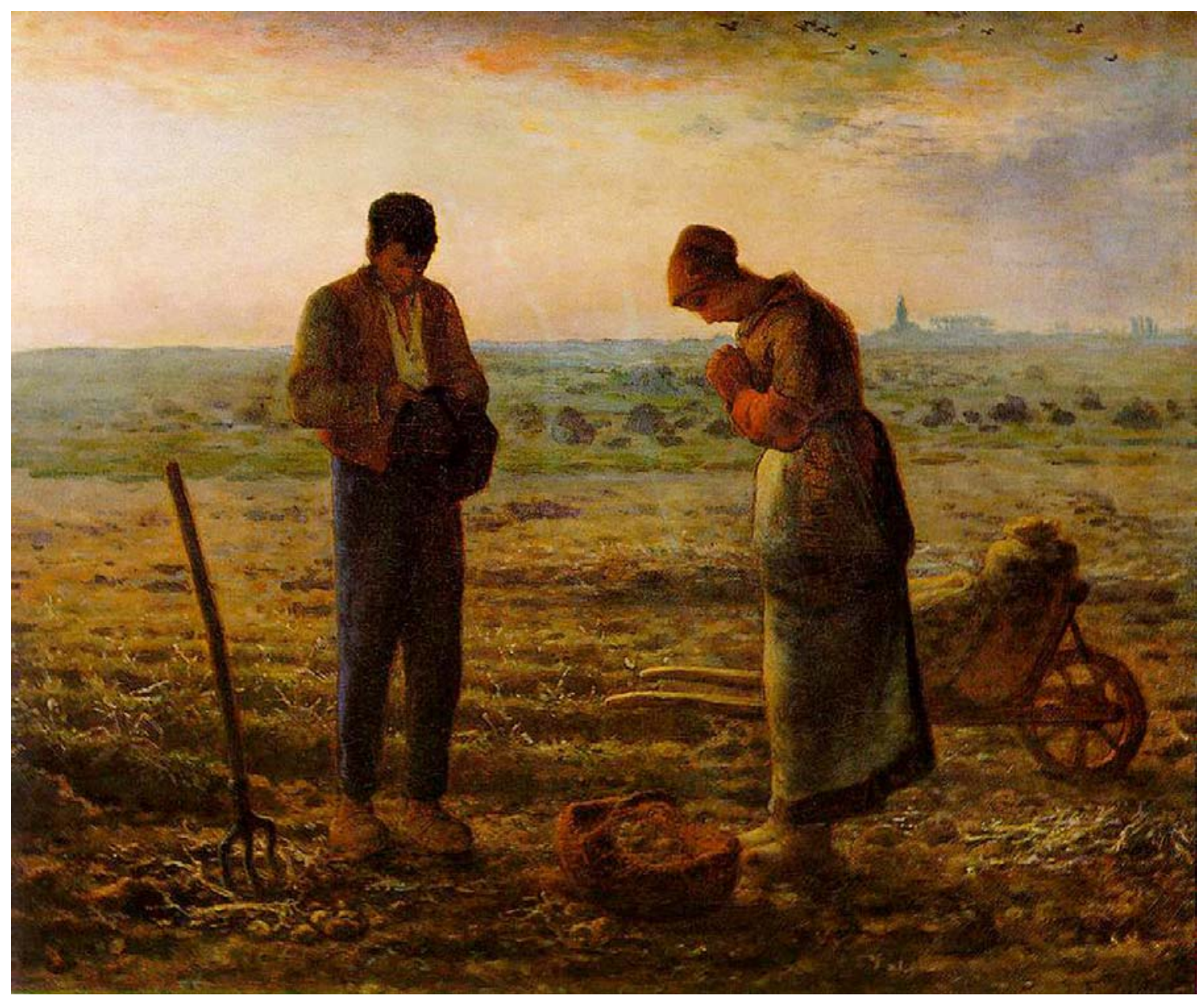

Figura 3: Jean- François Millet, O Ângelus, 1858 - 59. 


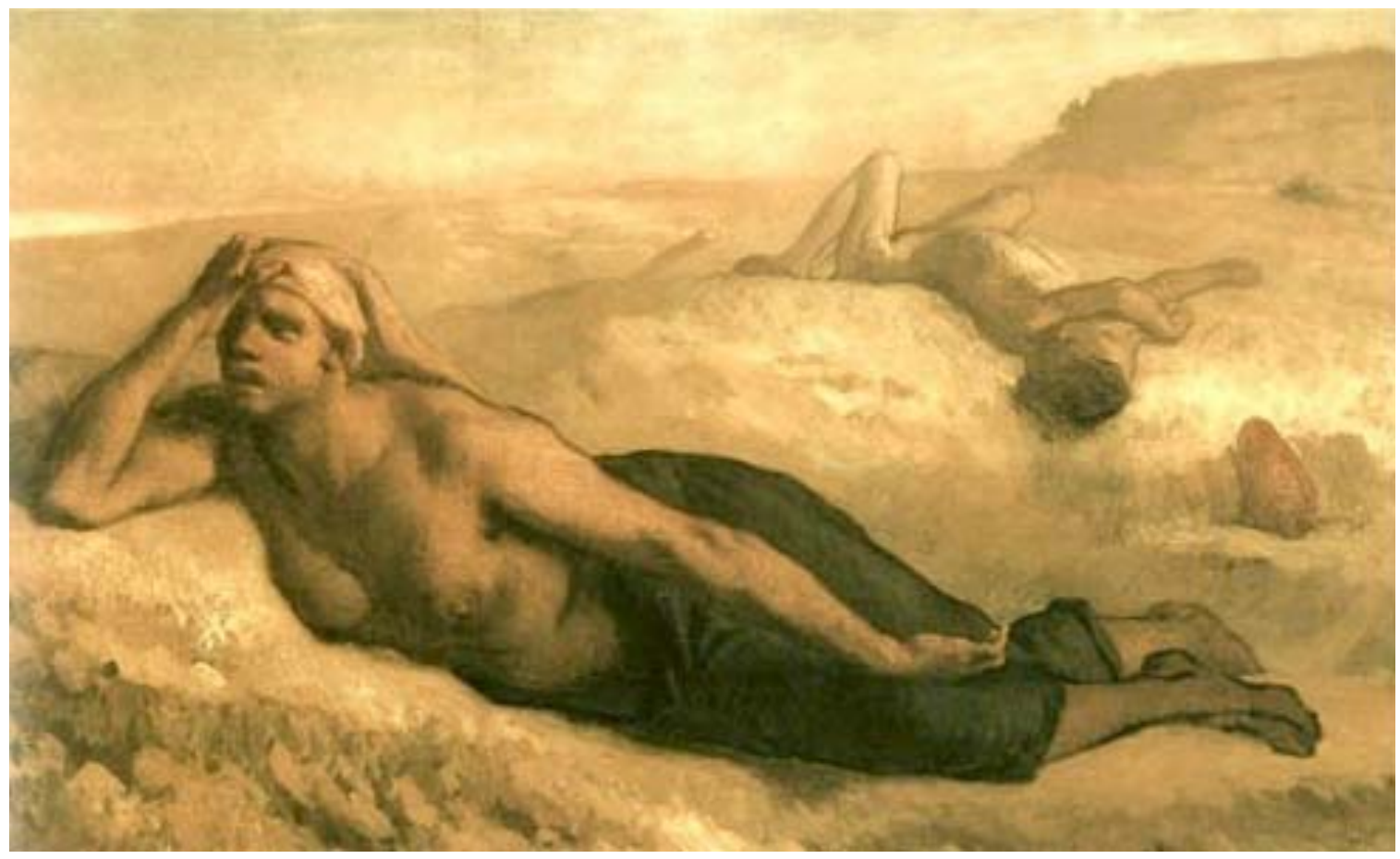

Figura 4: Jean-François Millet, Agar e Ismael, 1848 - 49. 


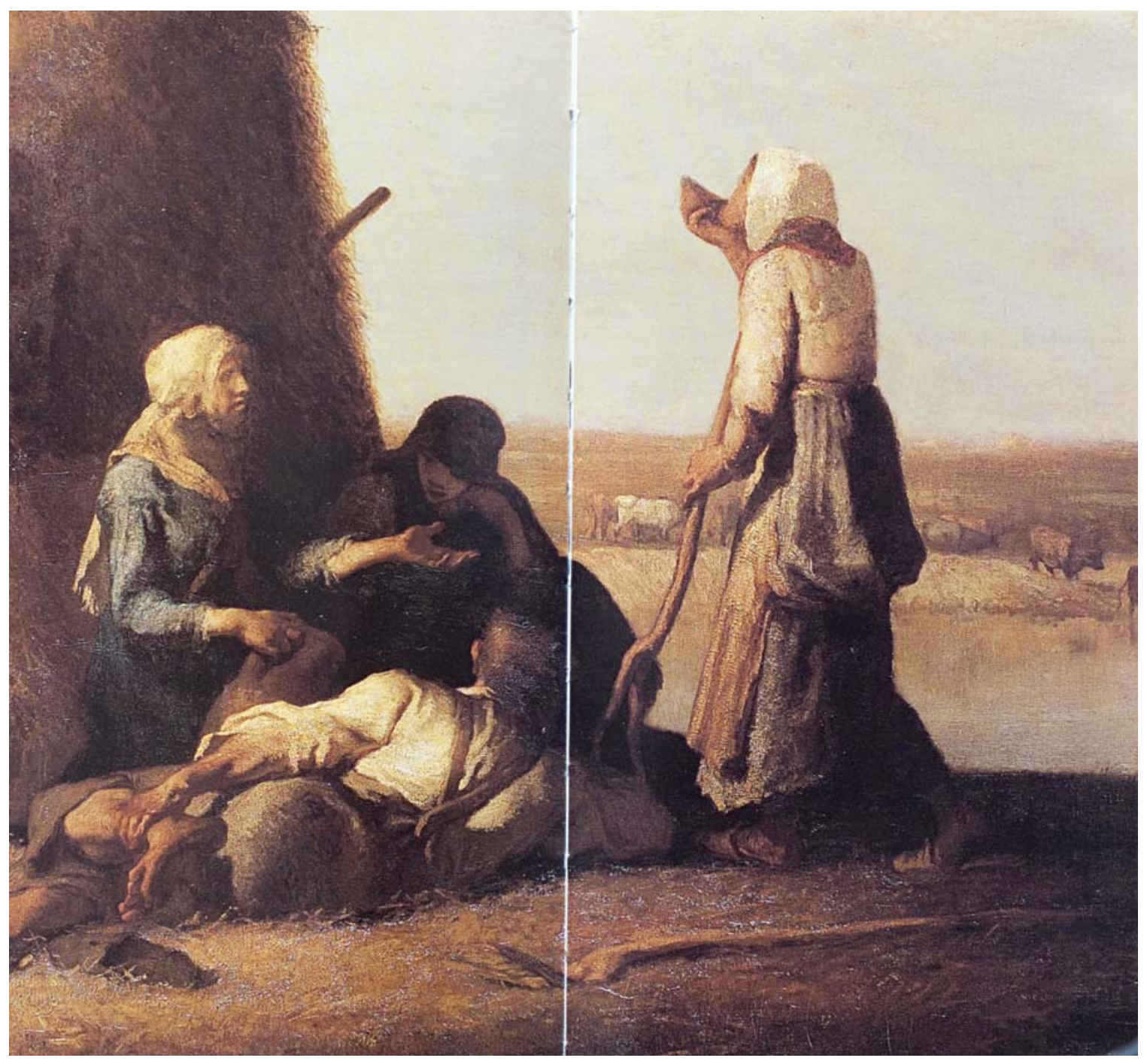

Figura 5: Jean-François Millet, O descanso dos lavradores, 1849. 


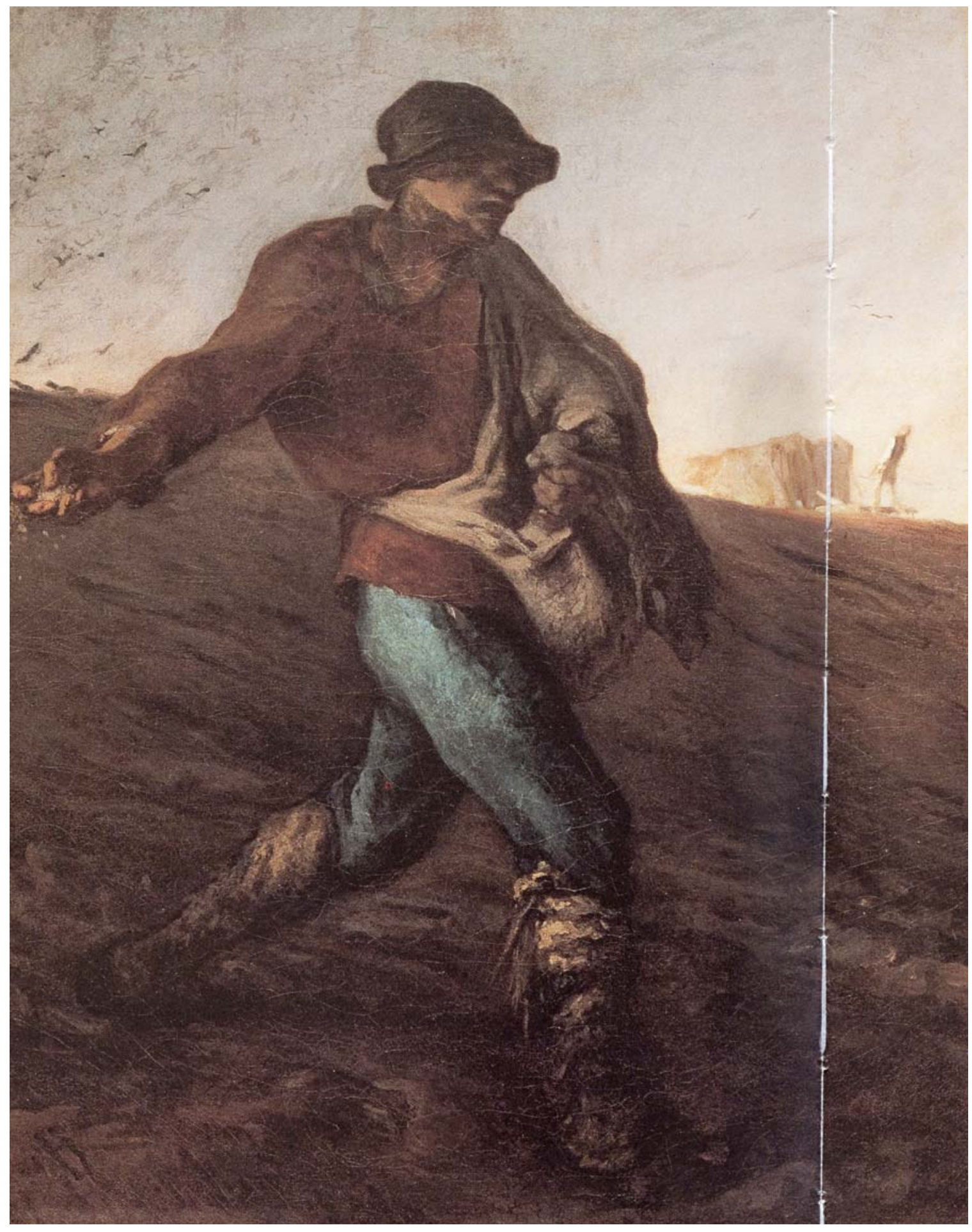

Figura 6: Jean-François Millet, O semeador, 1850. 


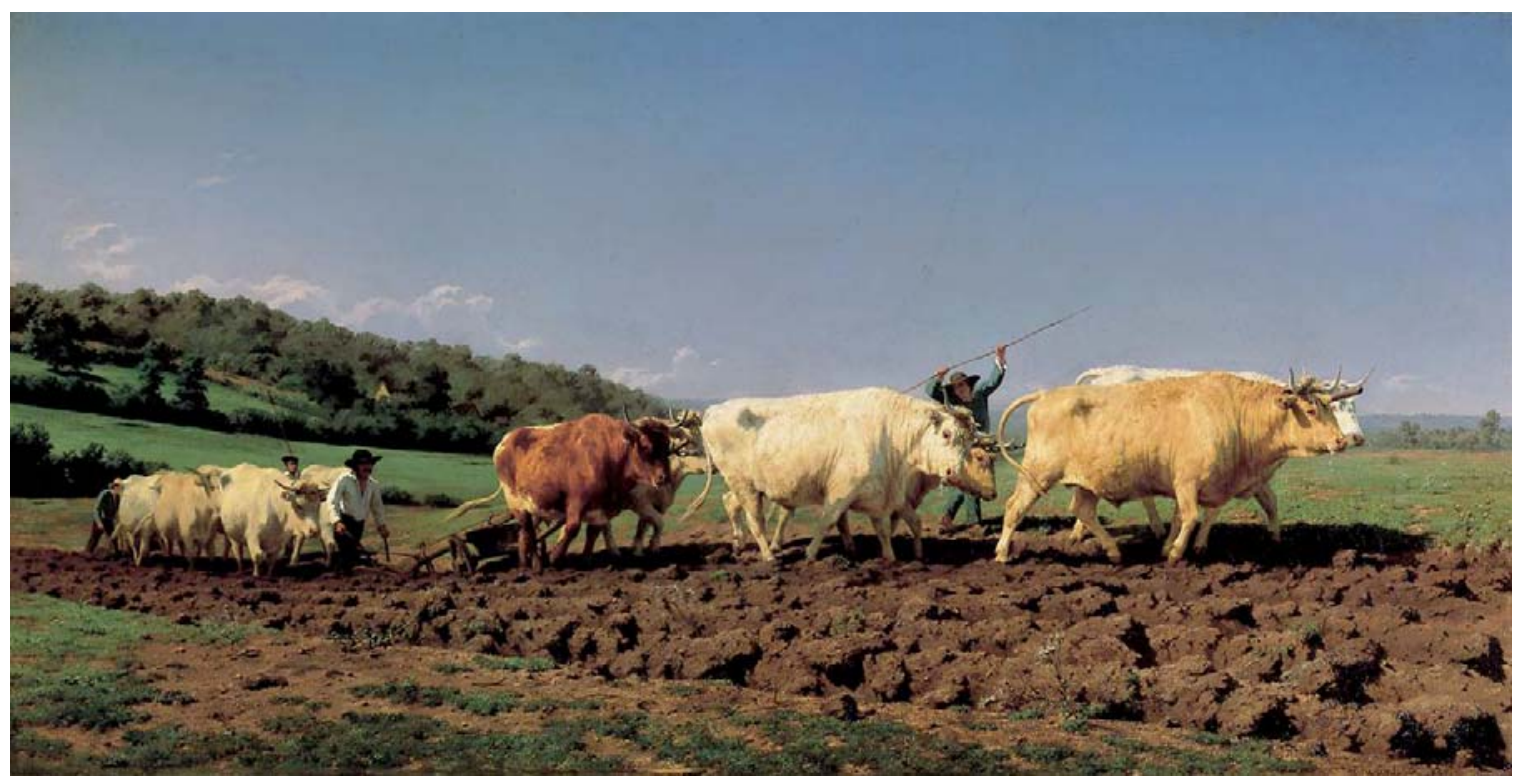

Figura 7: Rosa Bonheur, Lavragem em Nevers: primeira lavra de vinha, 1849. 


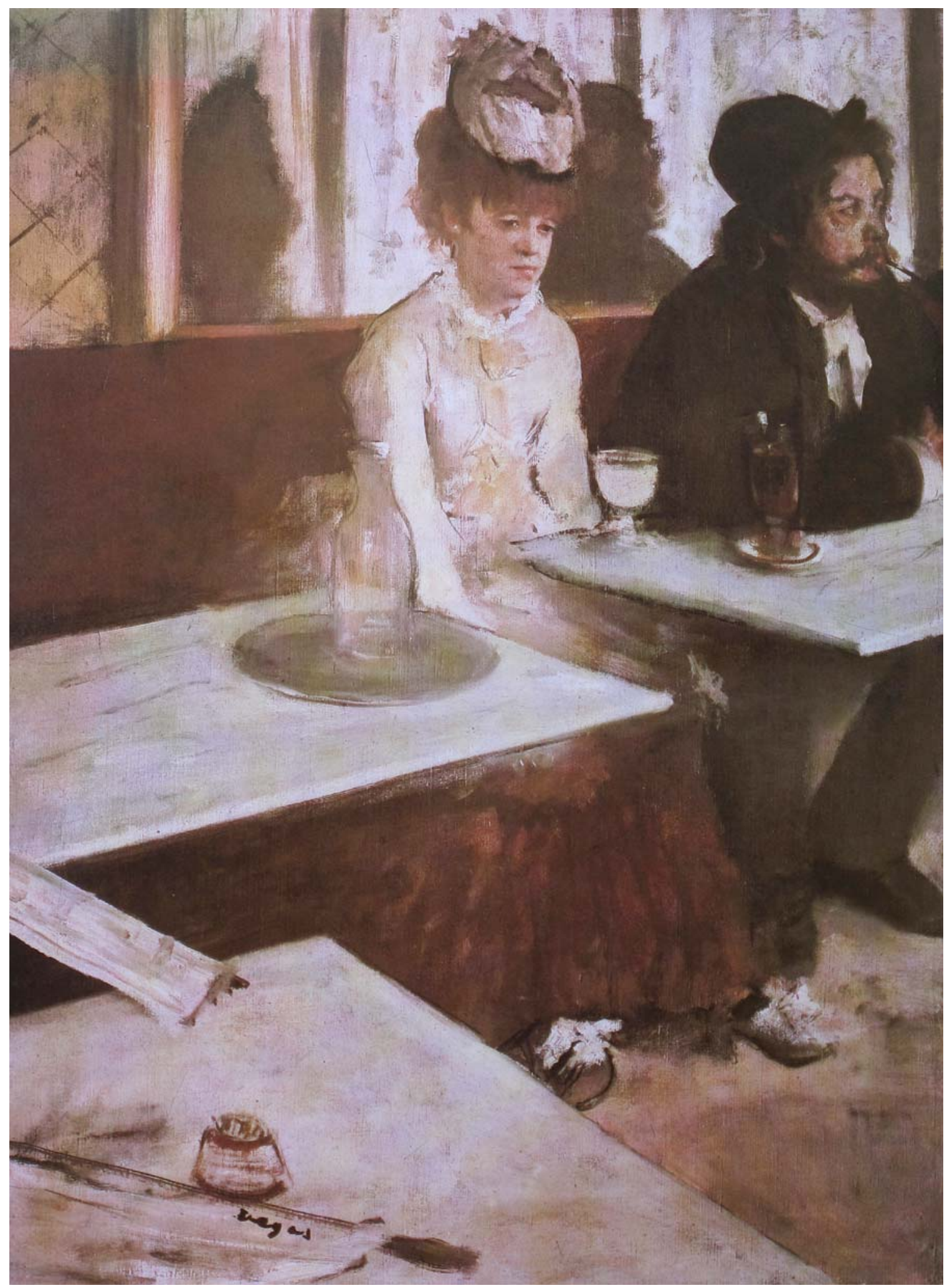

Figura 8: Edgar Degas, O absinto, 1876. 


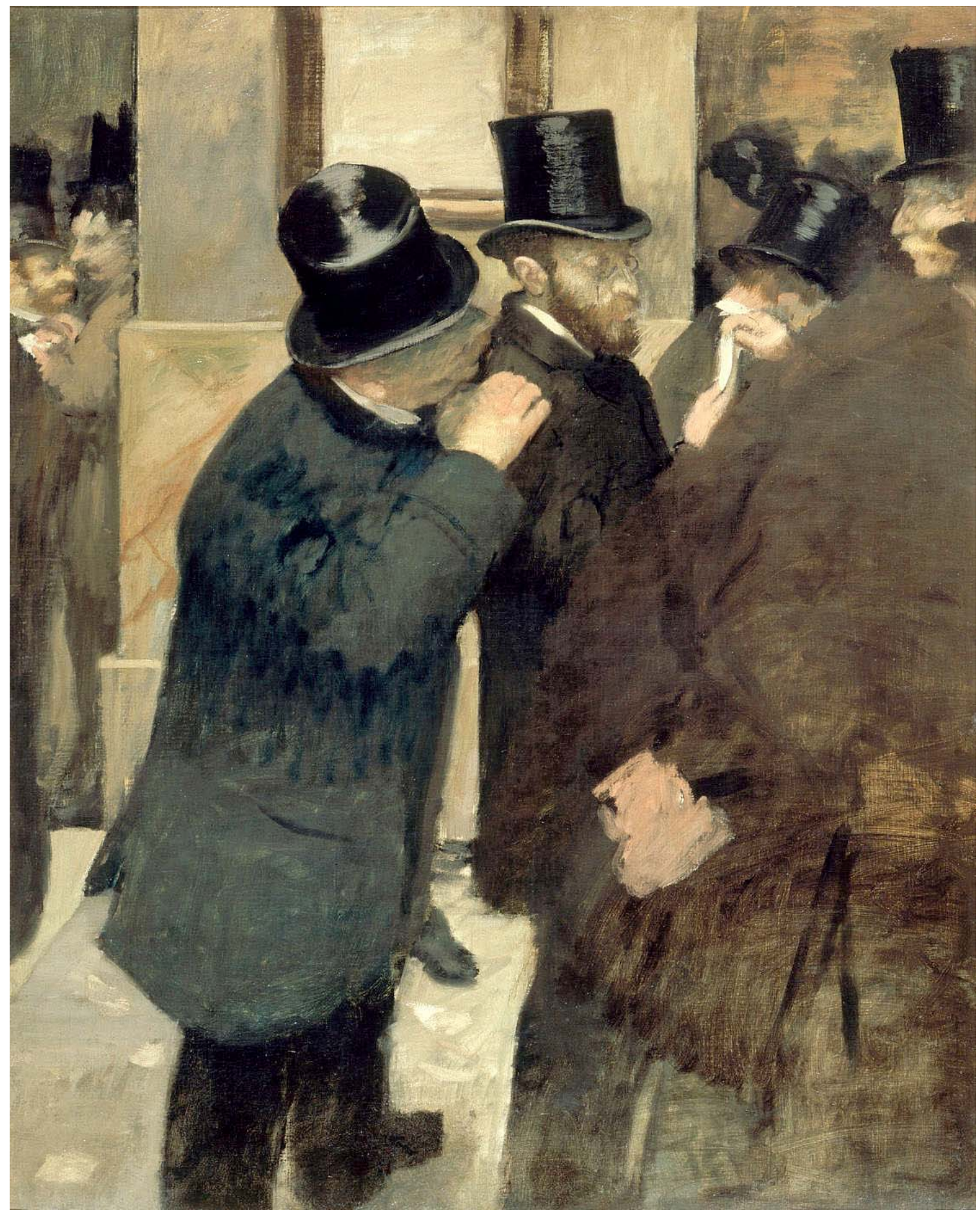

Figura 9: Edgard Degas, Na bolsa de valores, 1879. 


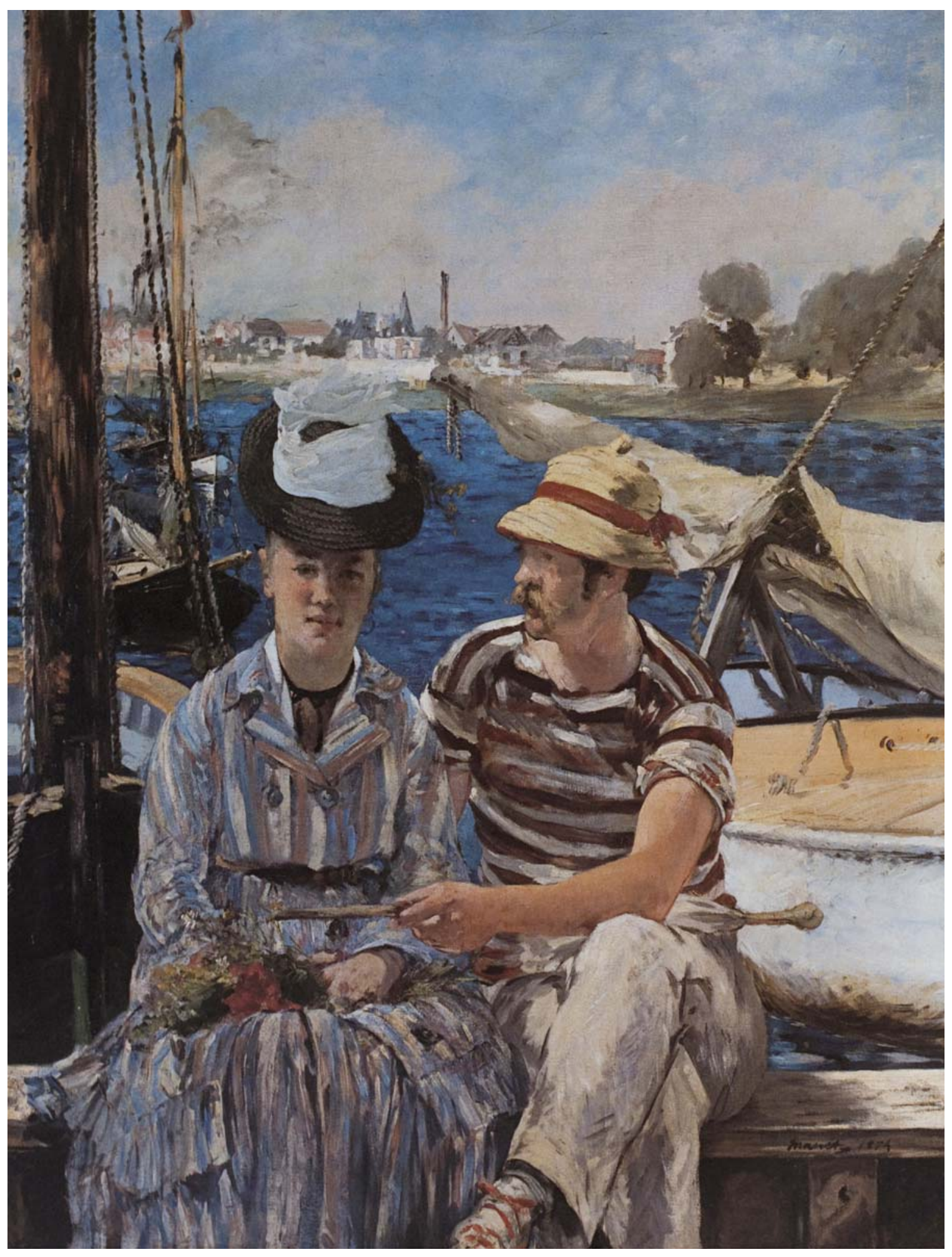

Figura 10: Édouard Manet, Barqueiros em Argenteuil, 1874. 


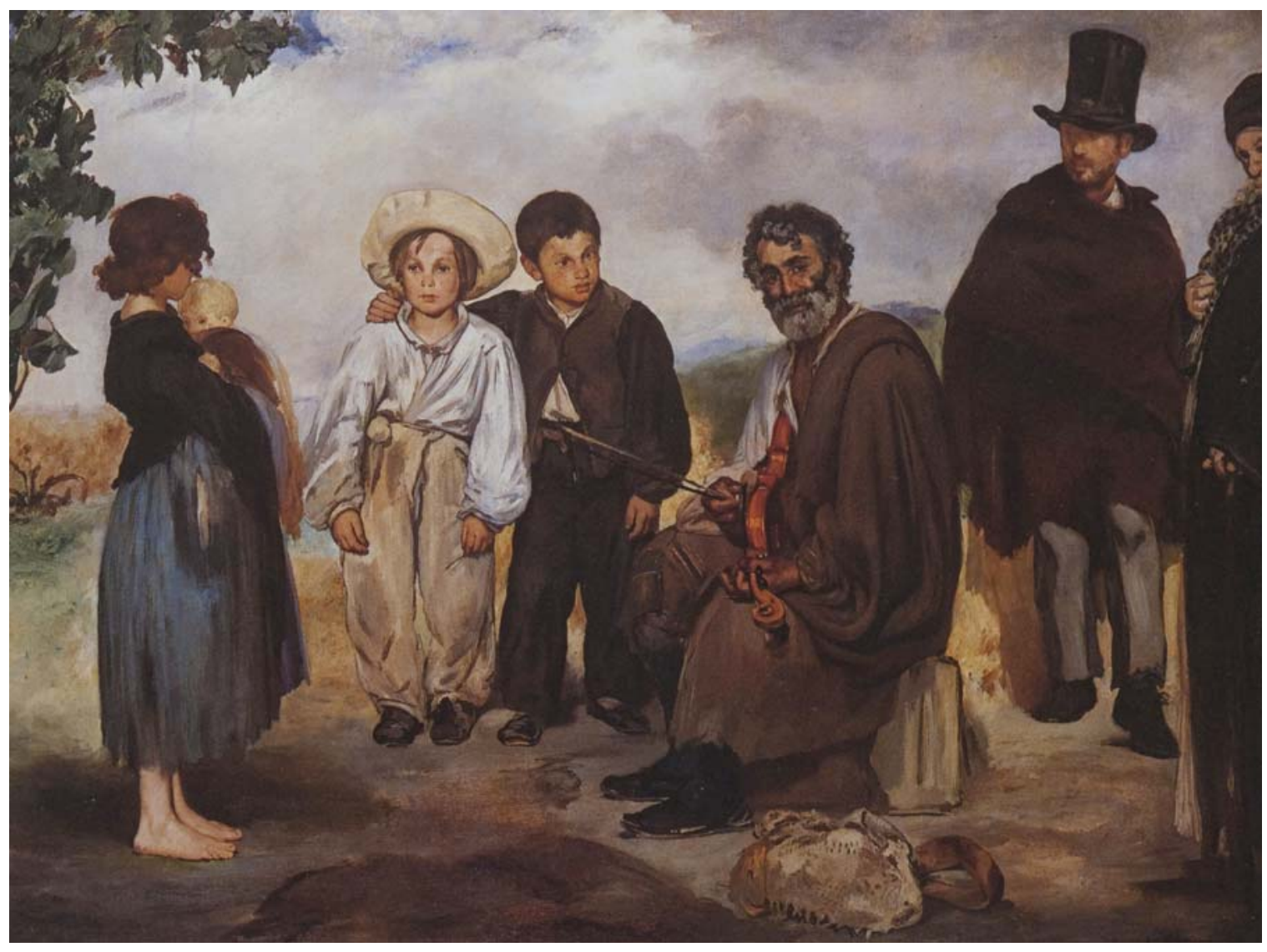

Figura 11: Édouard Manet, O velho músico, 1862. 


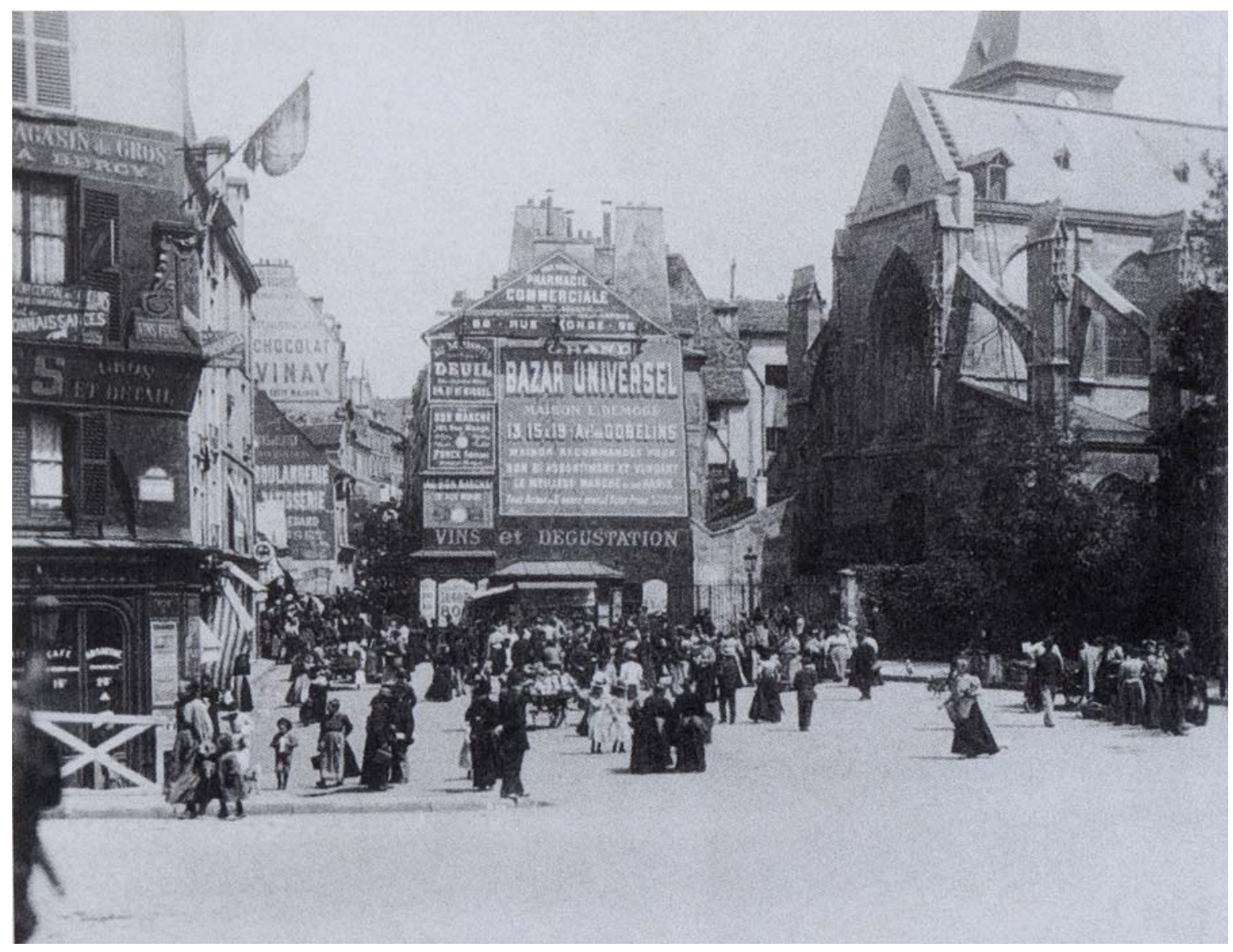

Figura 12: Eugène Atget, Praça Saint-Médard - vista geral, 1898. 


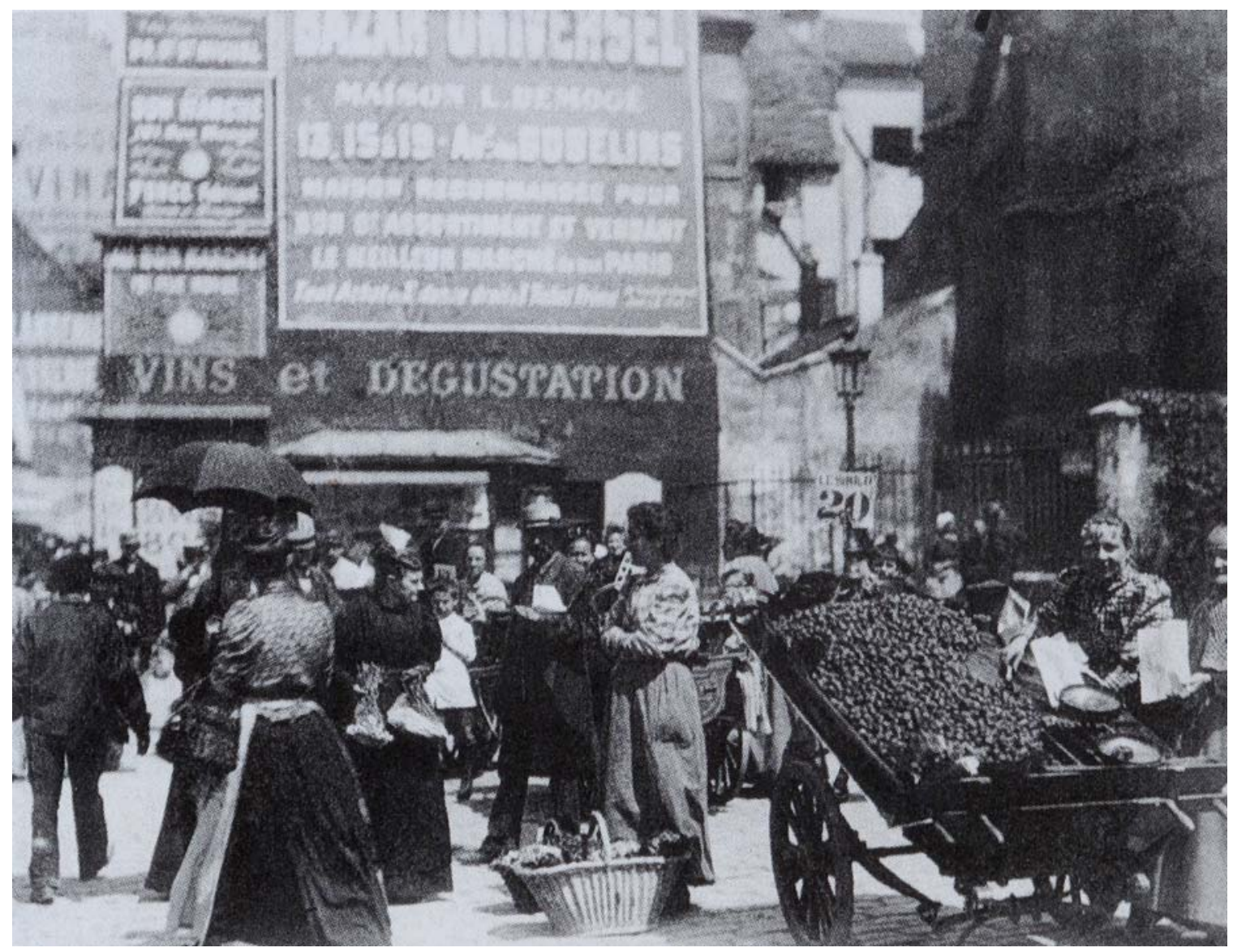

Figura 13: Eugène Atget, Praça Saint-Médard - detalhe, 1898. 


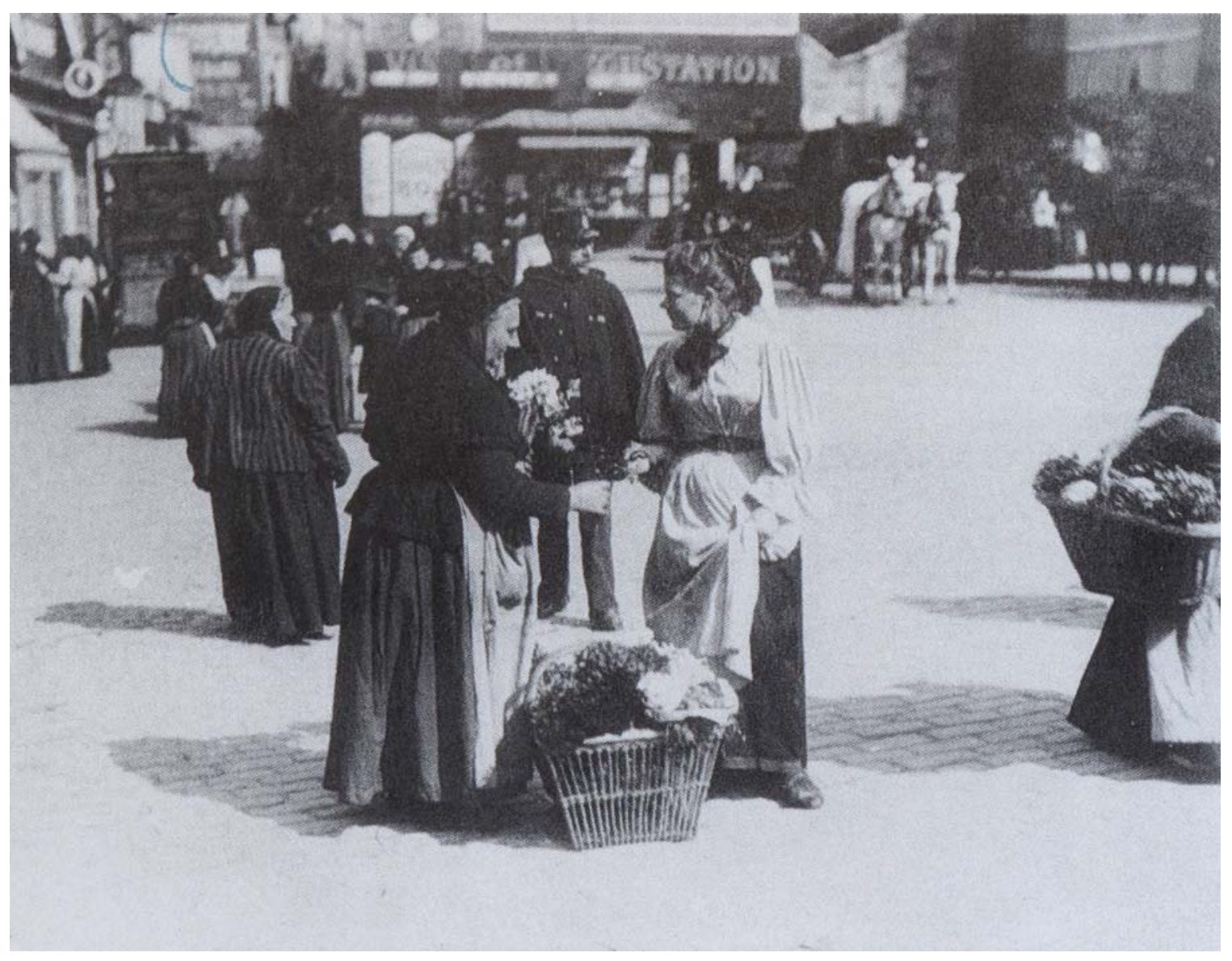

Figura 14: Eugène Atget, Praça Saint-Médard - detalhe, 1898. 


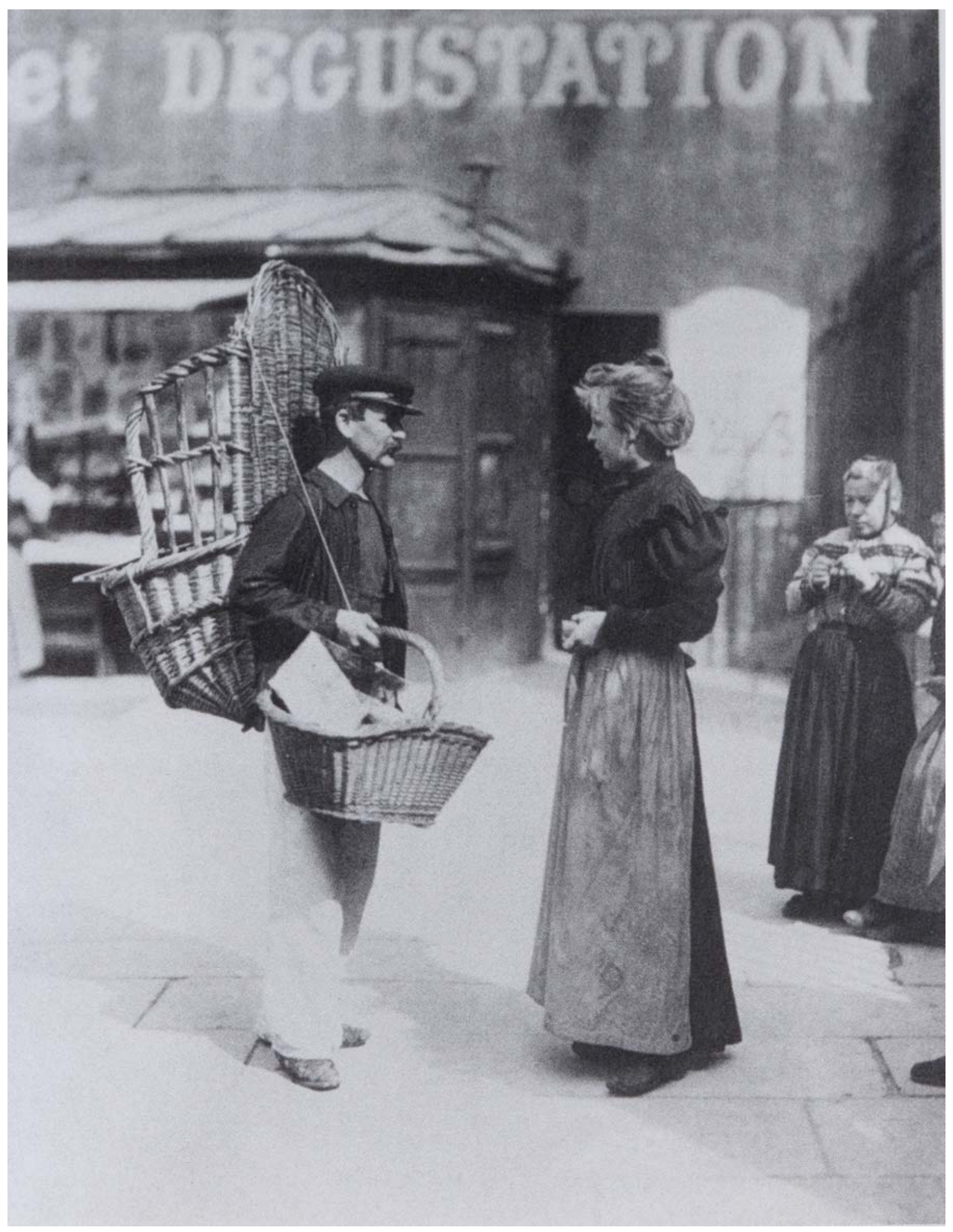

Figura 15: Eugène Atget, Vendedor ambulante de cestas, 1898 - 99. 


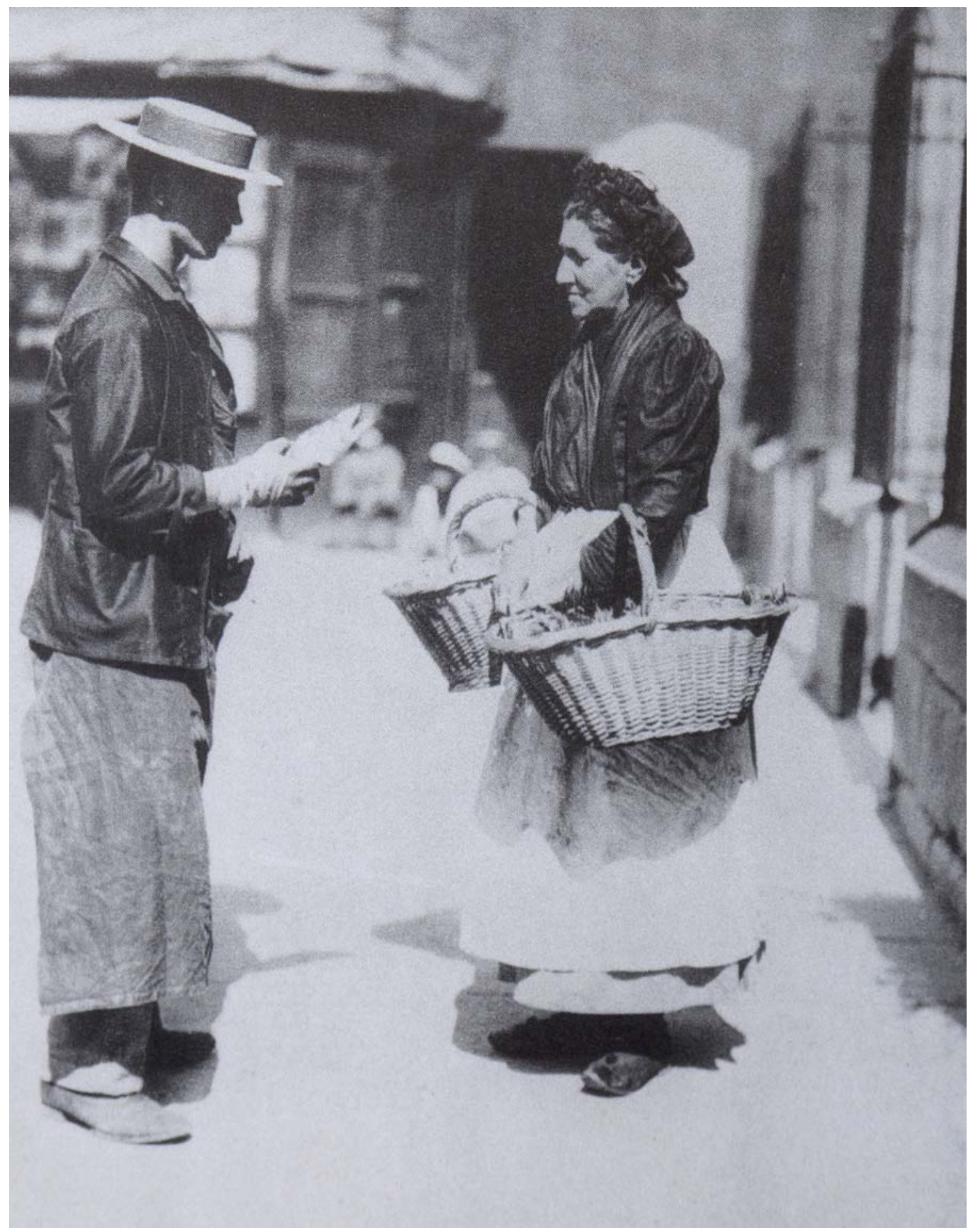

Figura 16: Eugène Atget, Praça Saint-Médard, 1899. 


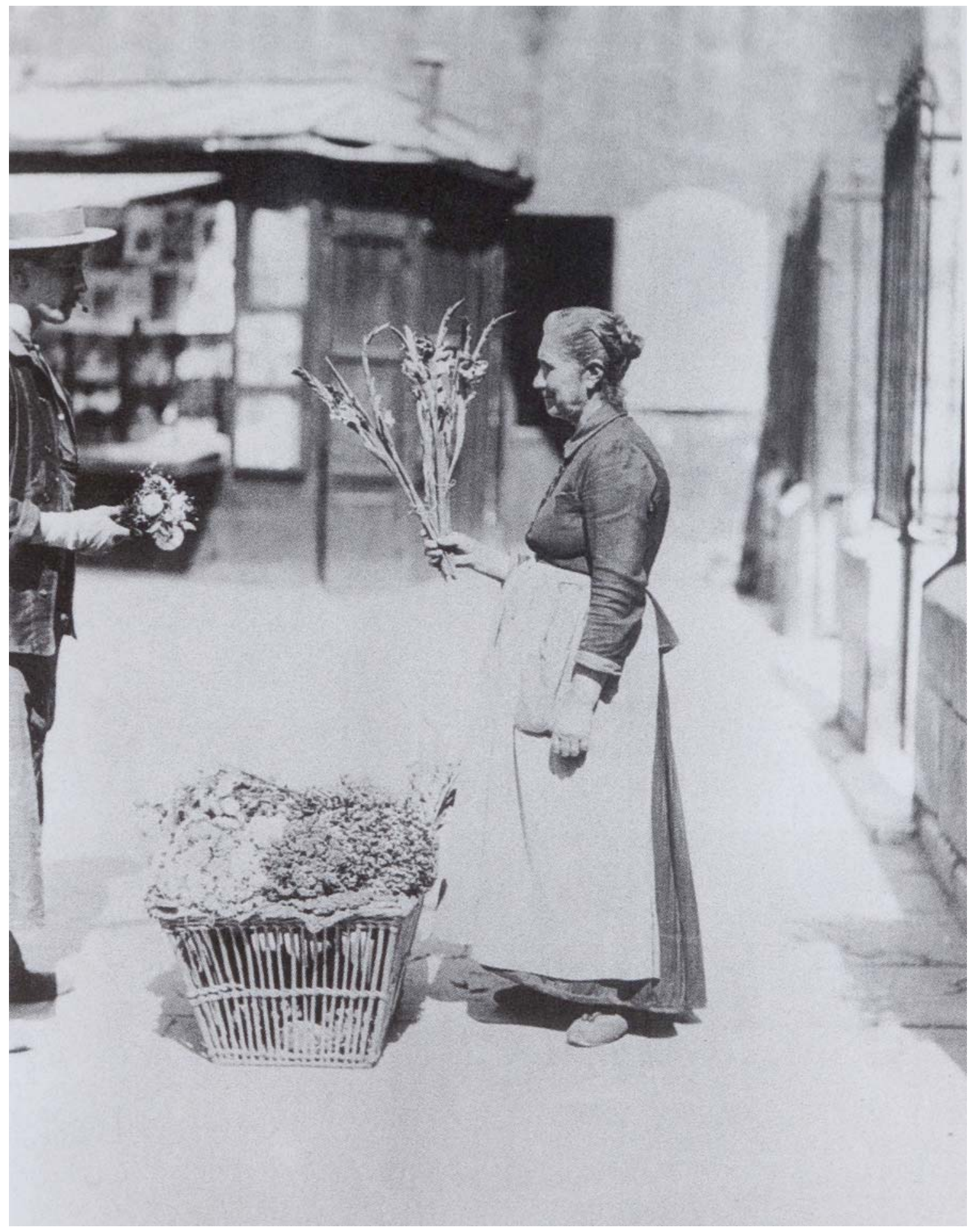

Figura 17: Eugène Atget, Praça Saint-Médard, 1899. 


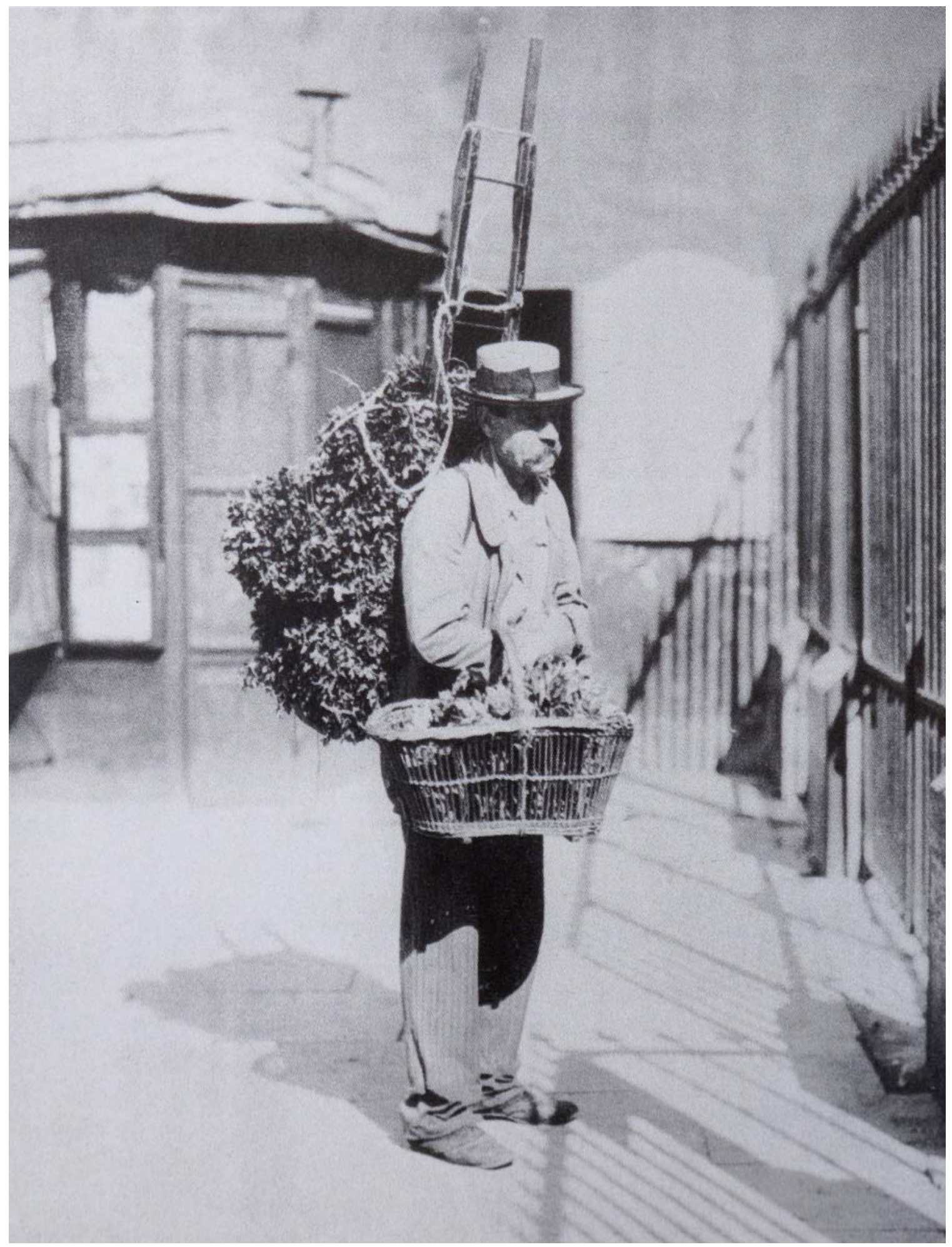

Figura 18: Eugène Atget, Vendedor de alcachofra, 1899. 


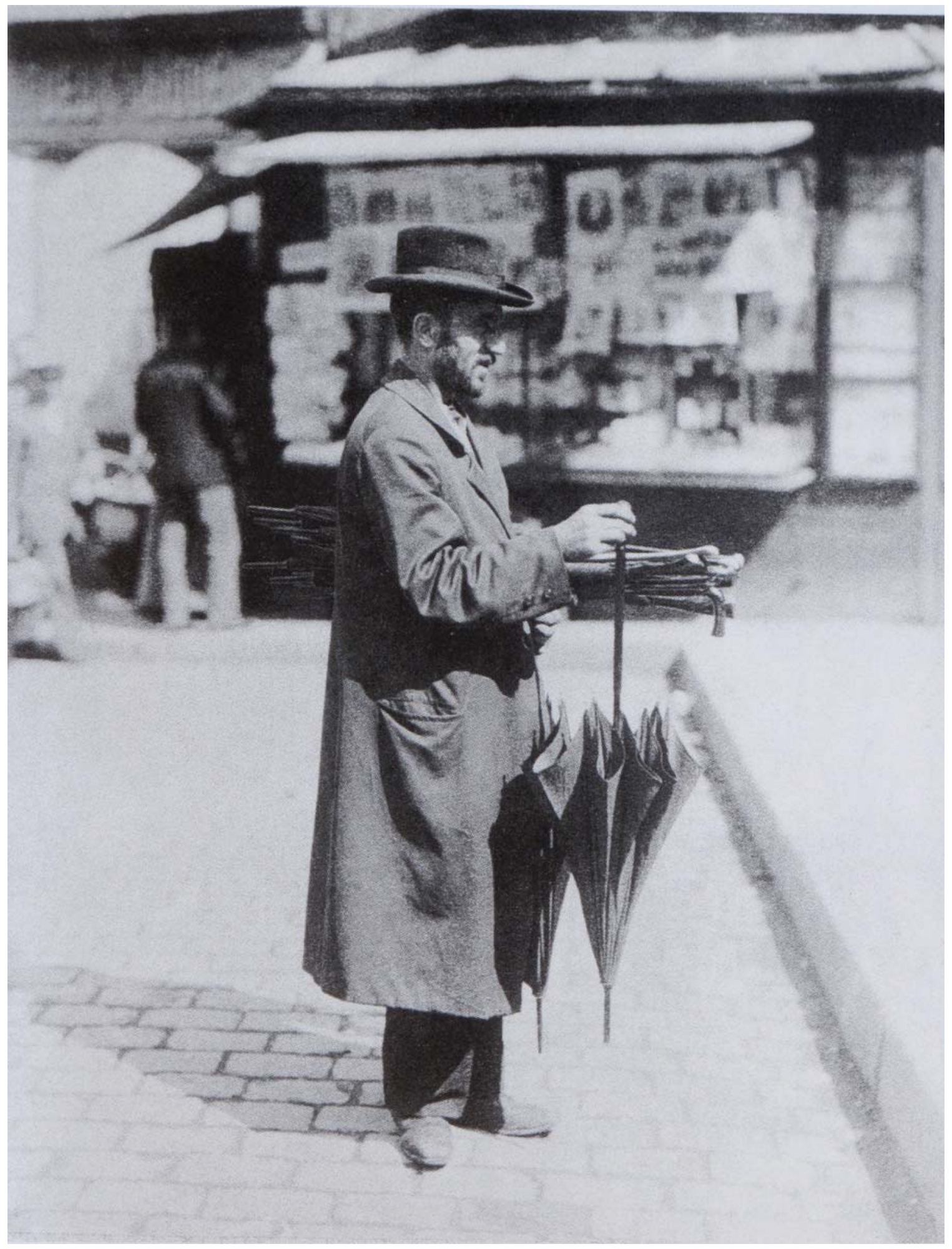

Figura 19: Eugène Atget, Vendedor de guarda-chuva, 1898 - 99. 


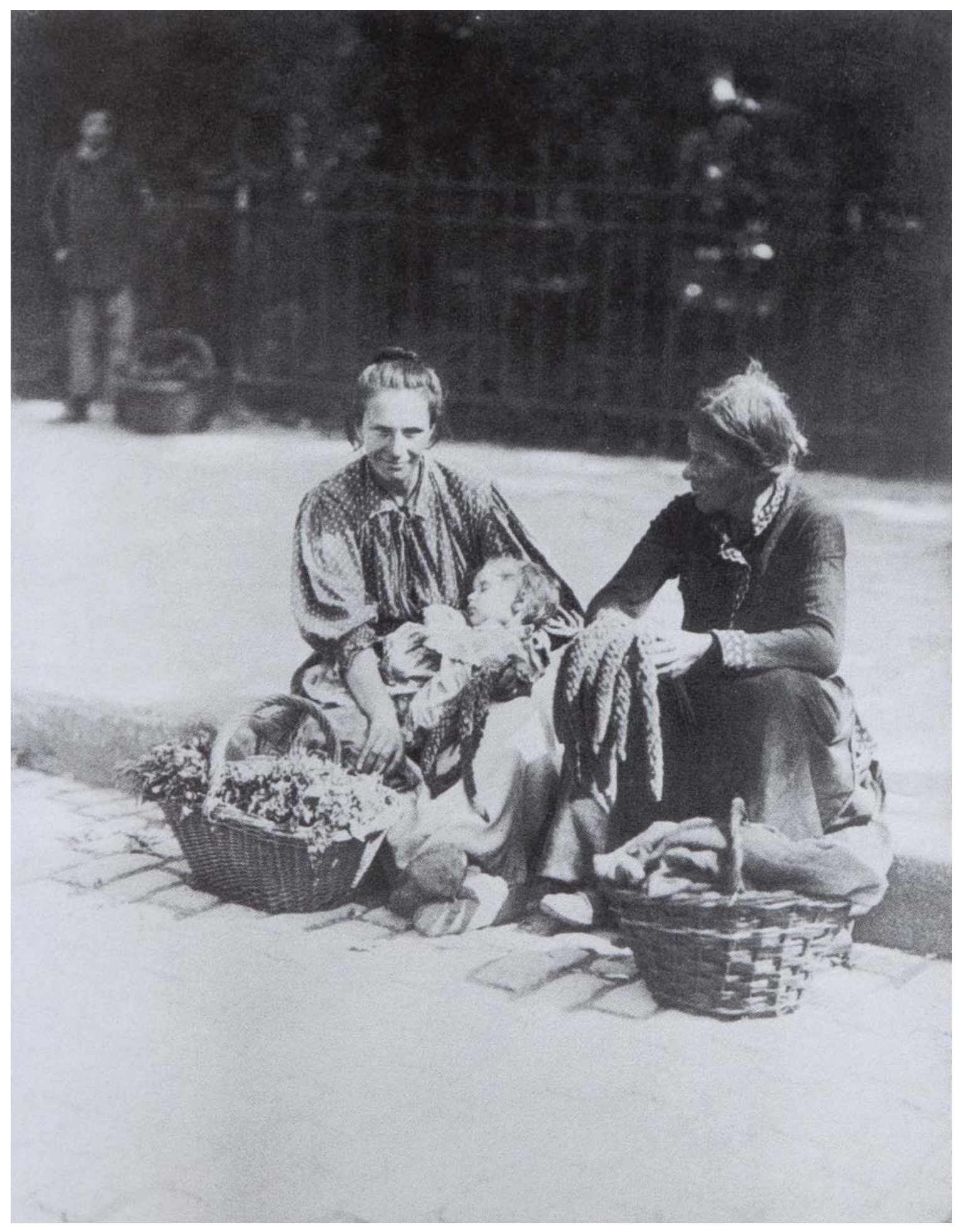

Figura 20: Eugène Atget, Vendedoras de ervas, 1899. 


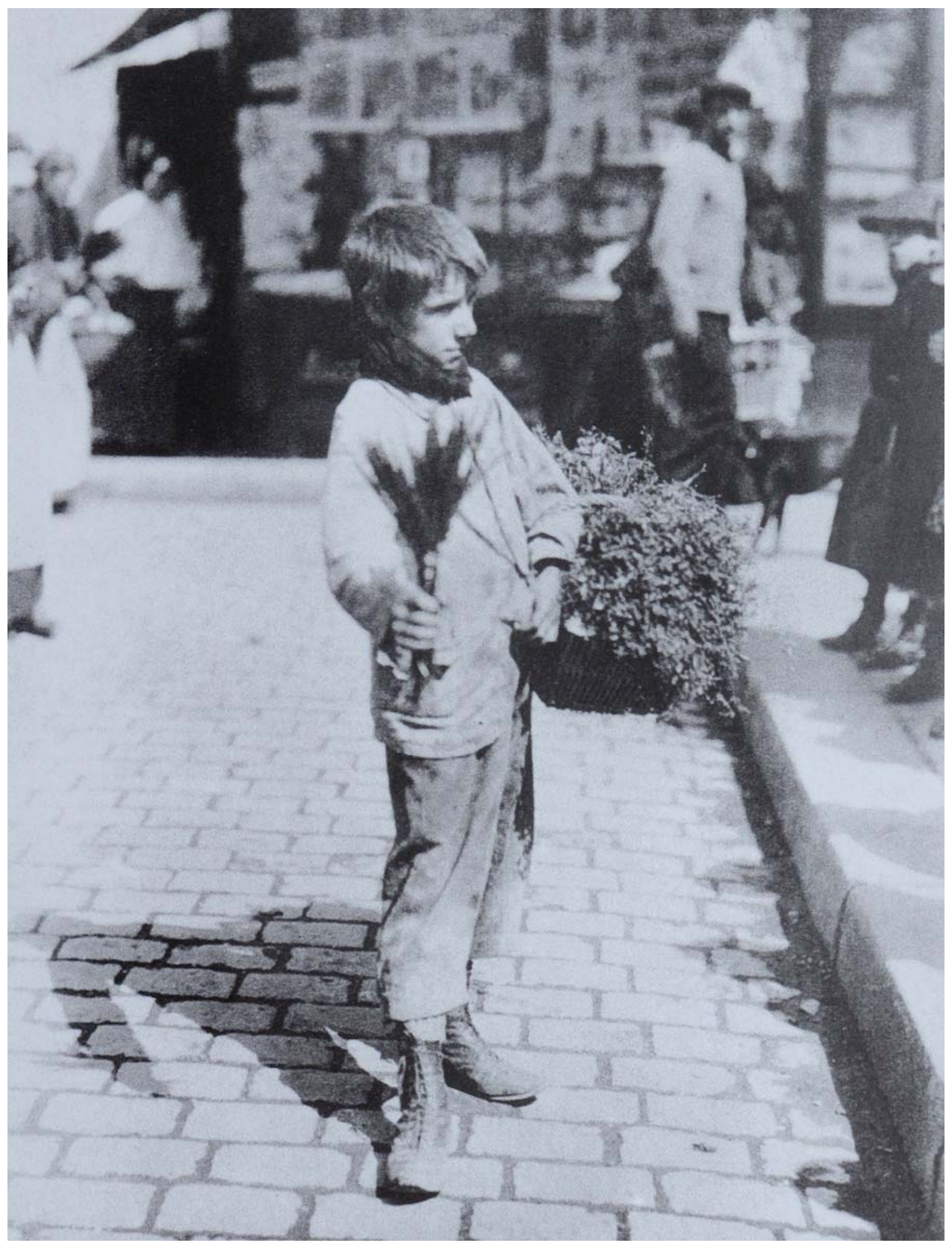

Figura 21: Eugène Atget, Vendedor de ervas, 1898 - 99. 


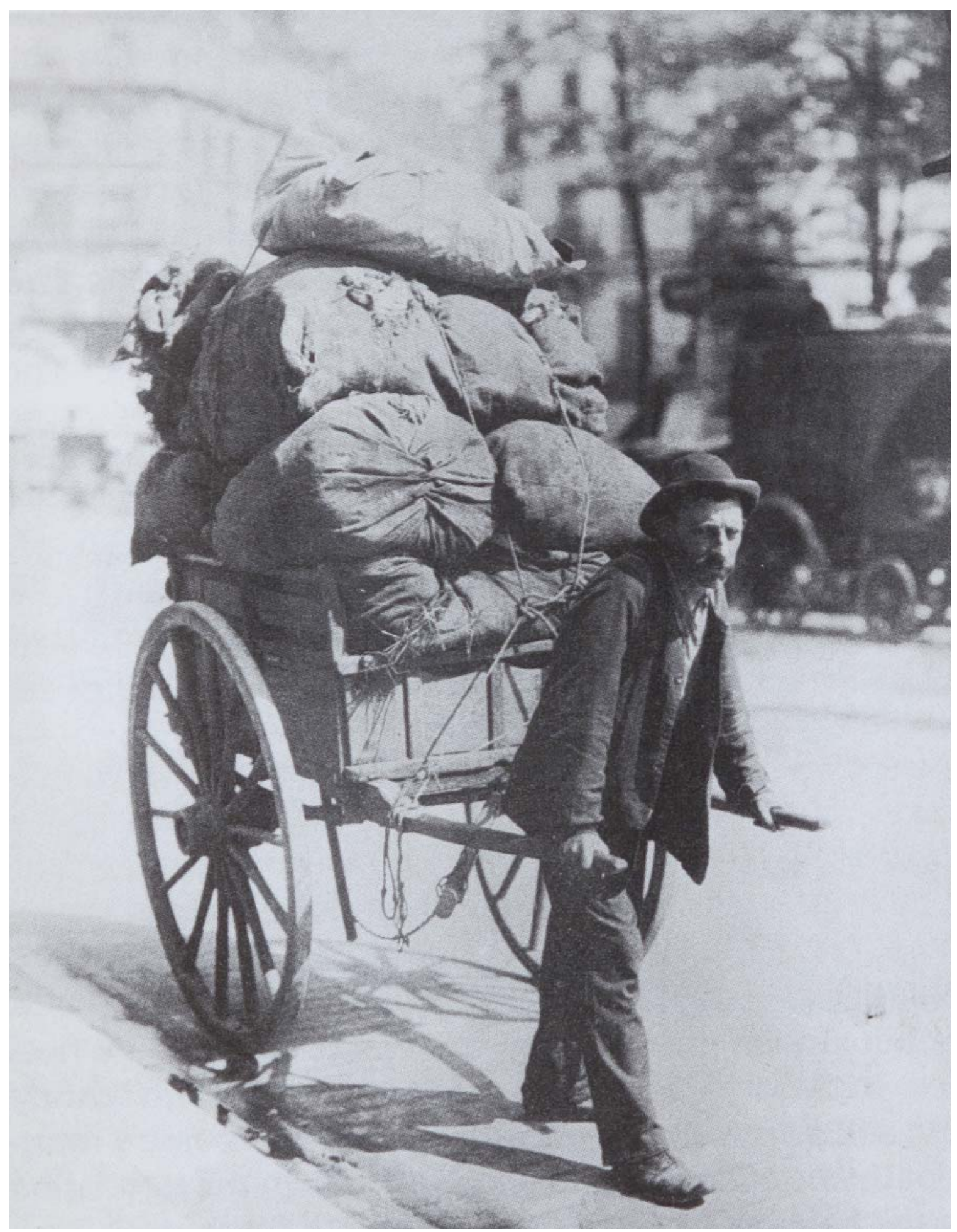

Figura 22: Eugène Atget, Chiffonnier, Avenue des Gobelins, 1901. 


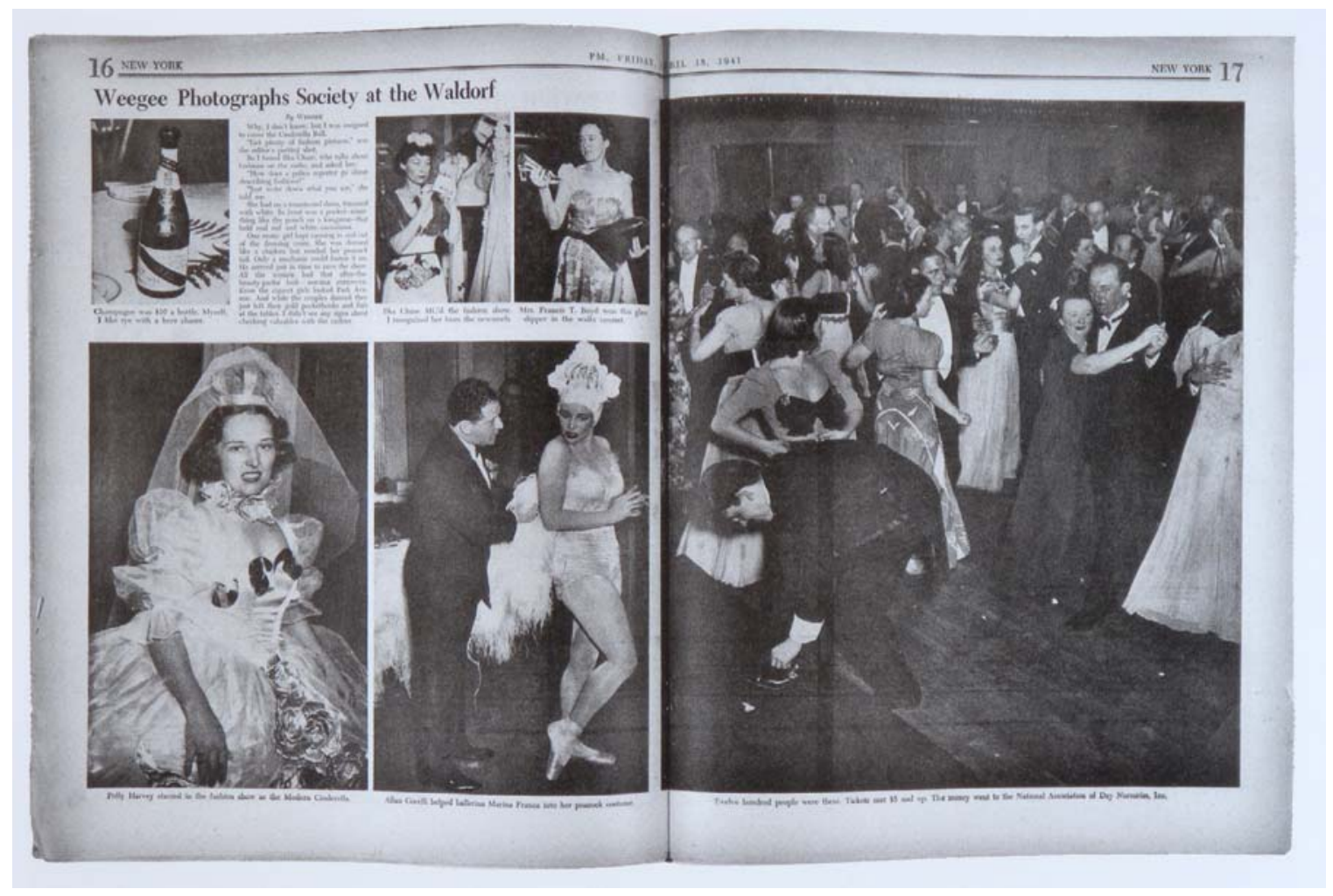

Figura 23: Weegee, "Weegee fotografa a sociedade no Waldorf", PM, 18 de abril de 1941. 
Figura 24: Weegee, Naked City, 1945. 


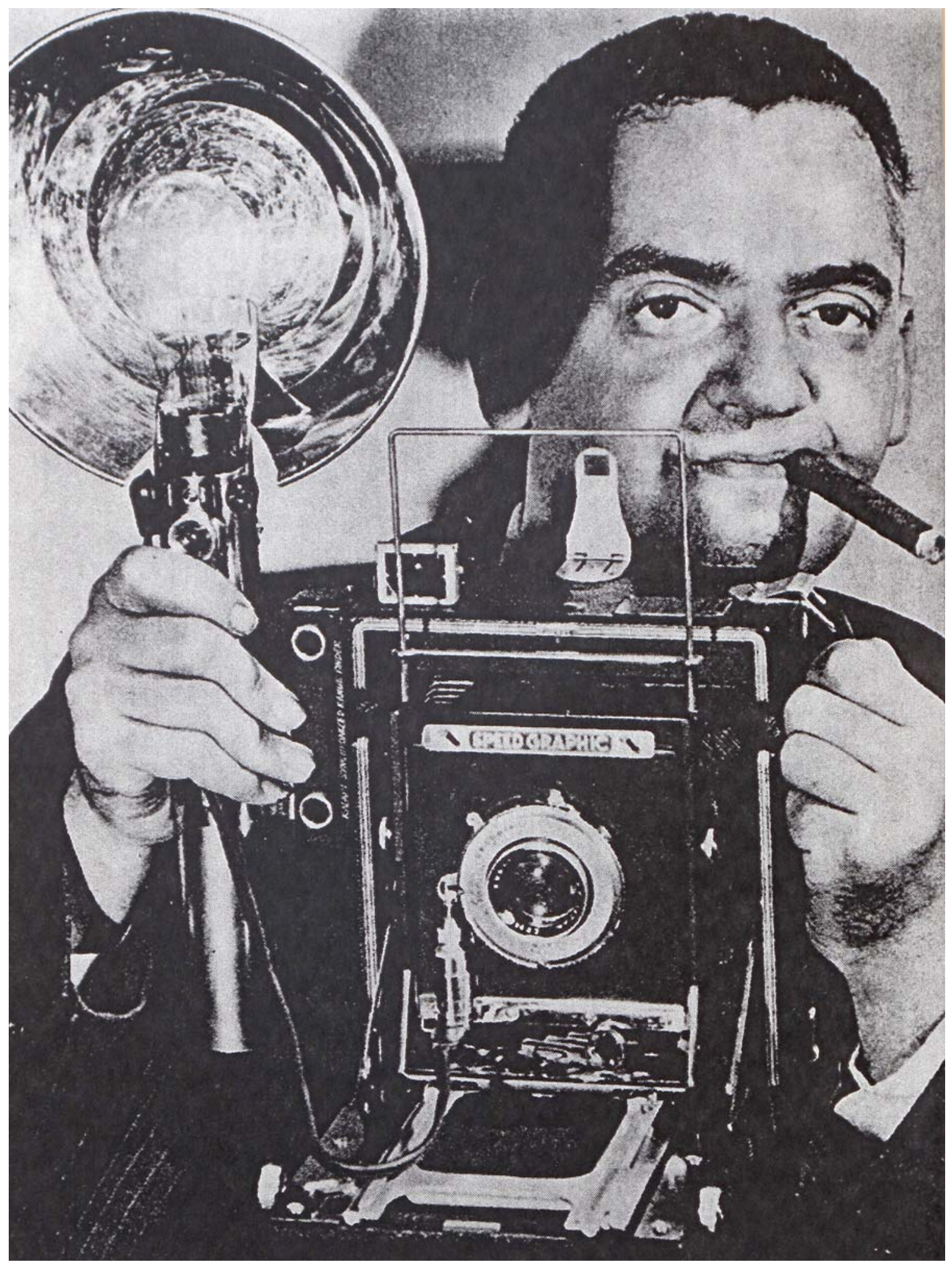

Figura 25: Weegee, Weegee e seu amor - sua câmera, Naked City, 1945. 


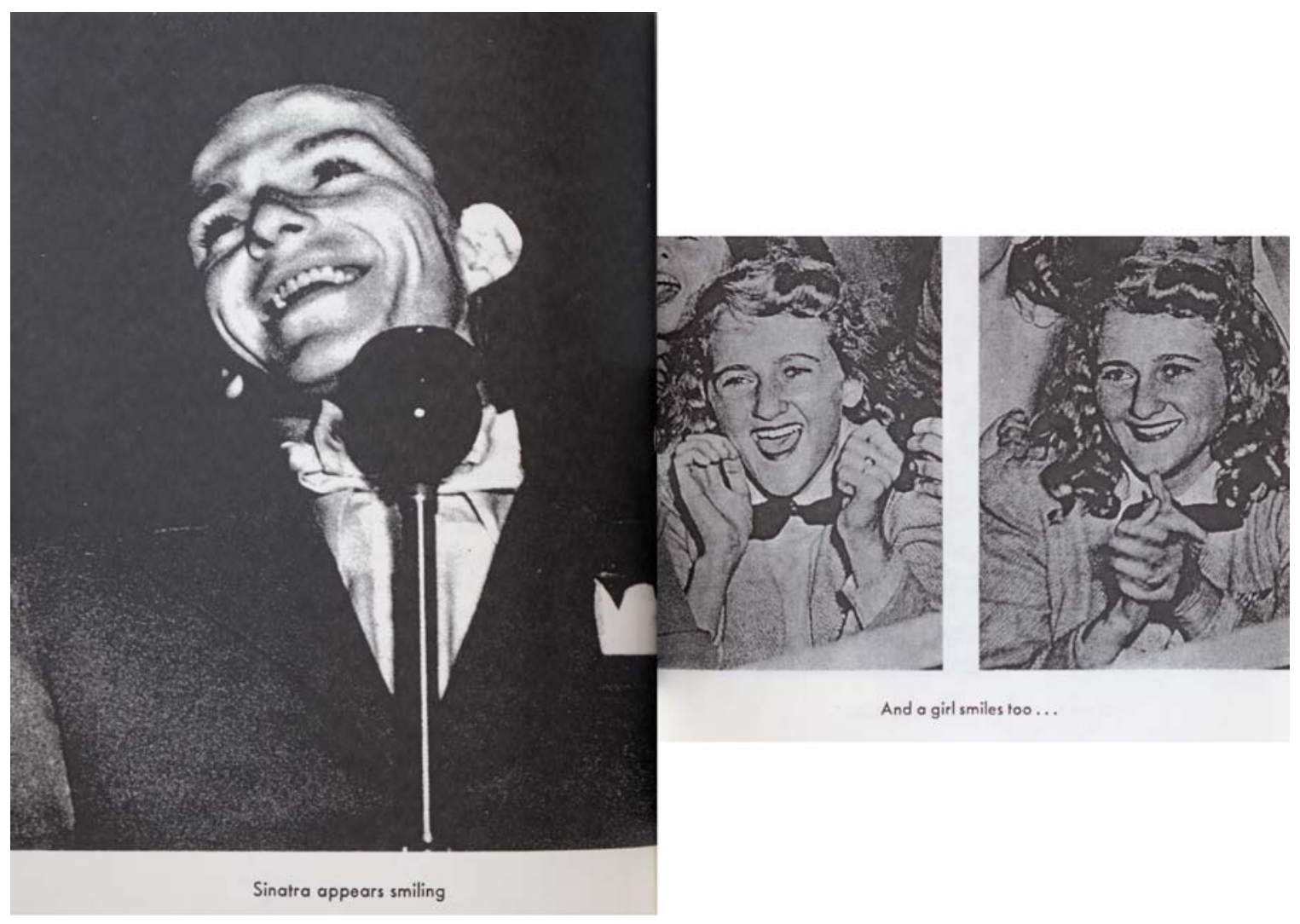

Figura 26: Weegee, primeira sequência de "Frankie", Naked City, 1945. 


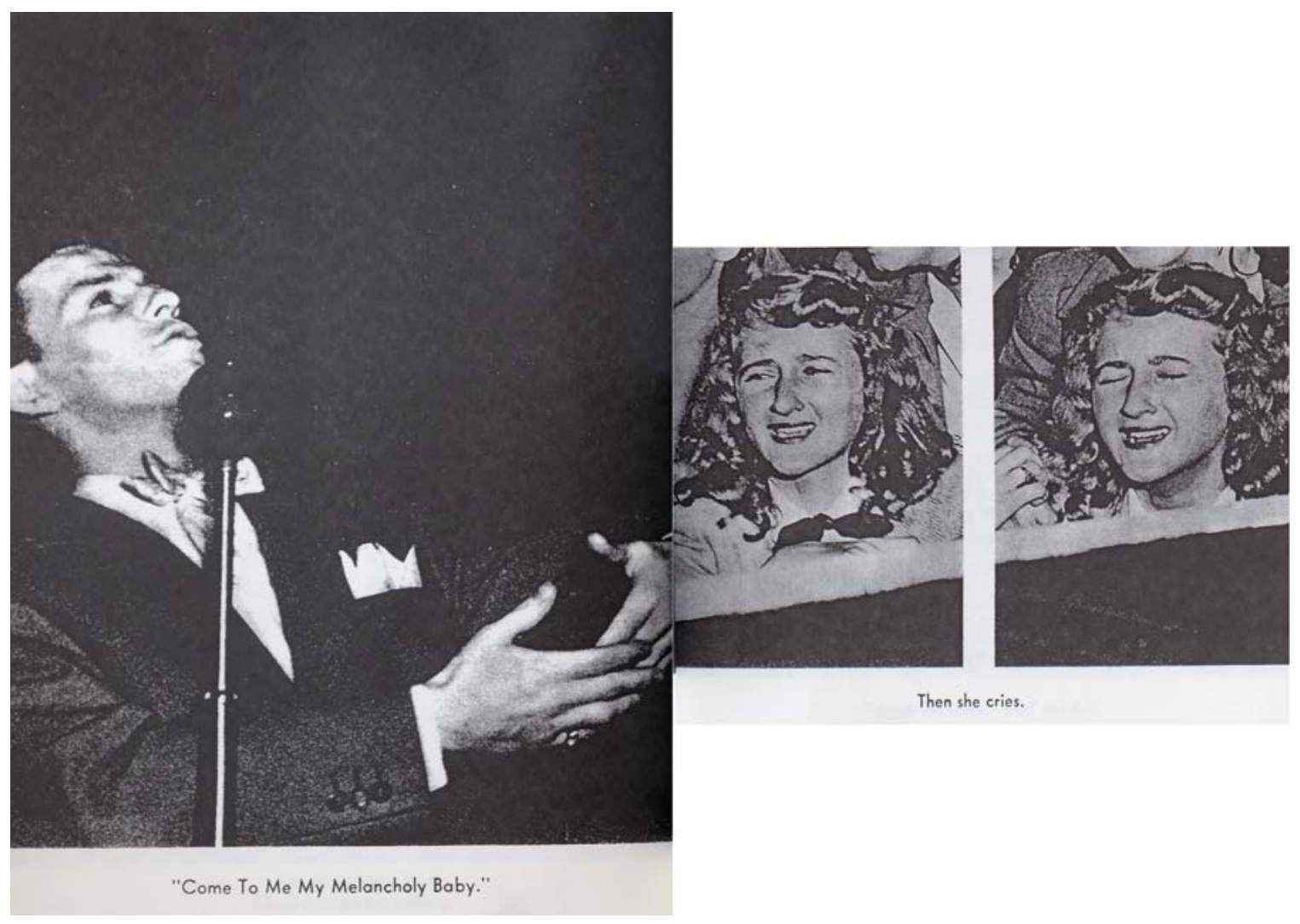

Figura 27: Weegee, segunda sequência de "Frankie", Naked City, 1945. 


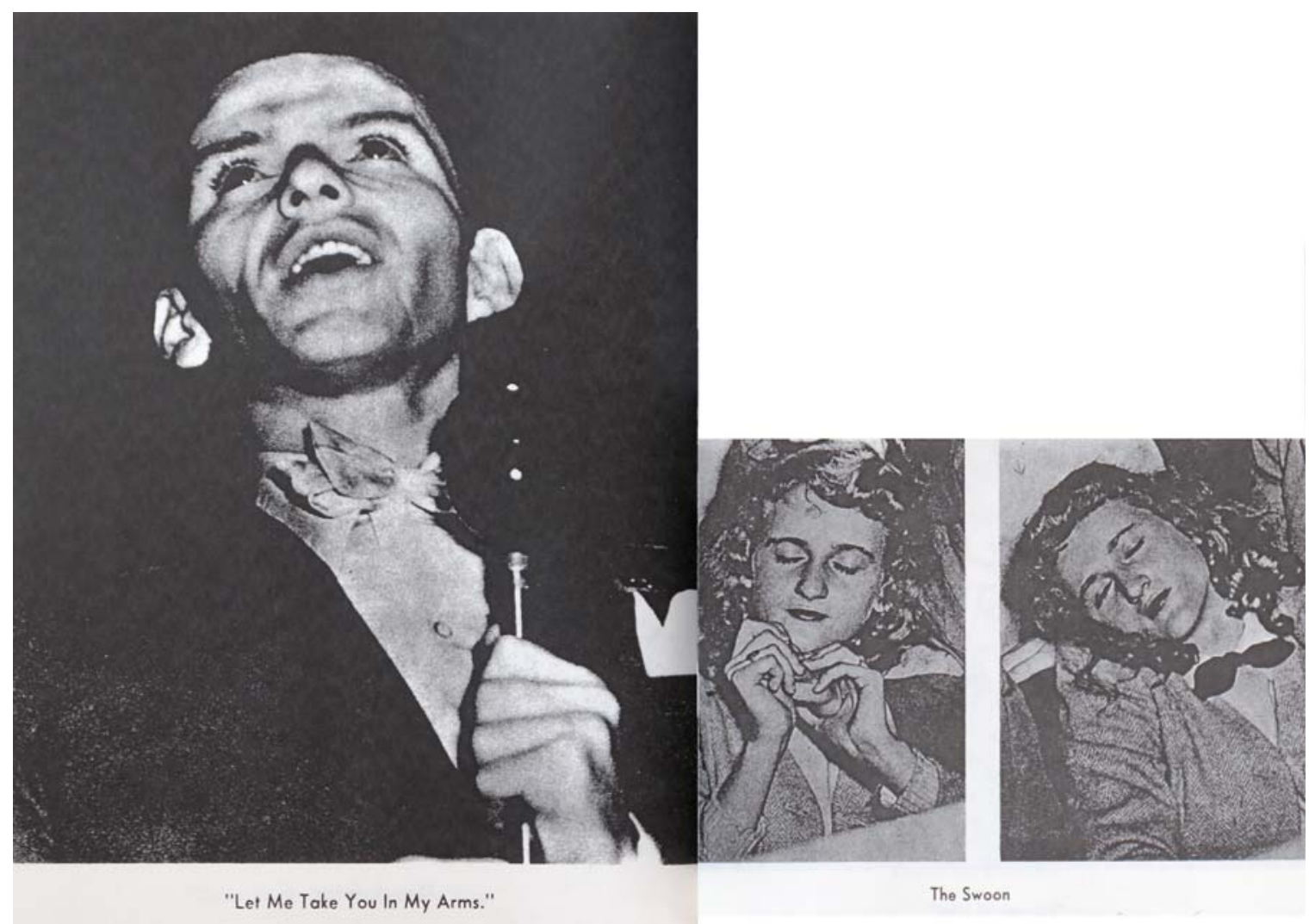

Figura 28: Weegee, terceira sequência de "Frankie", Naked City, 


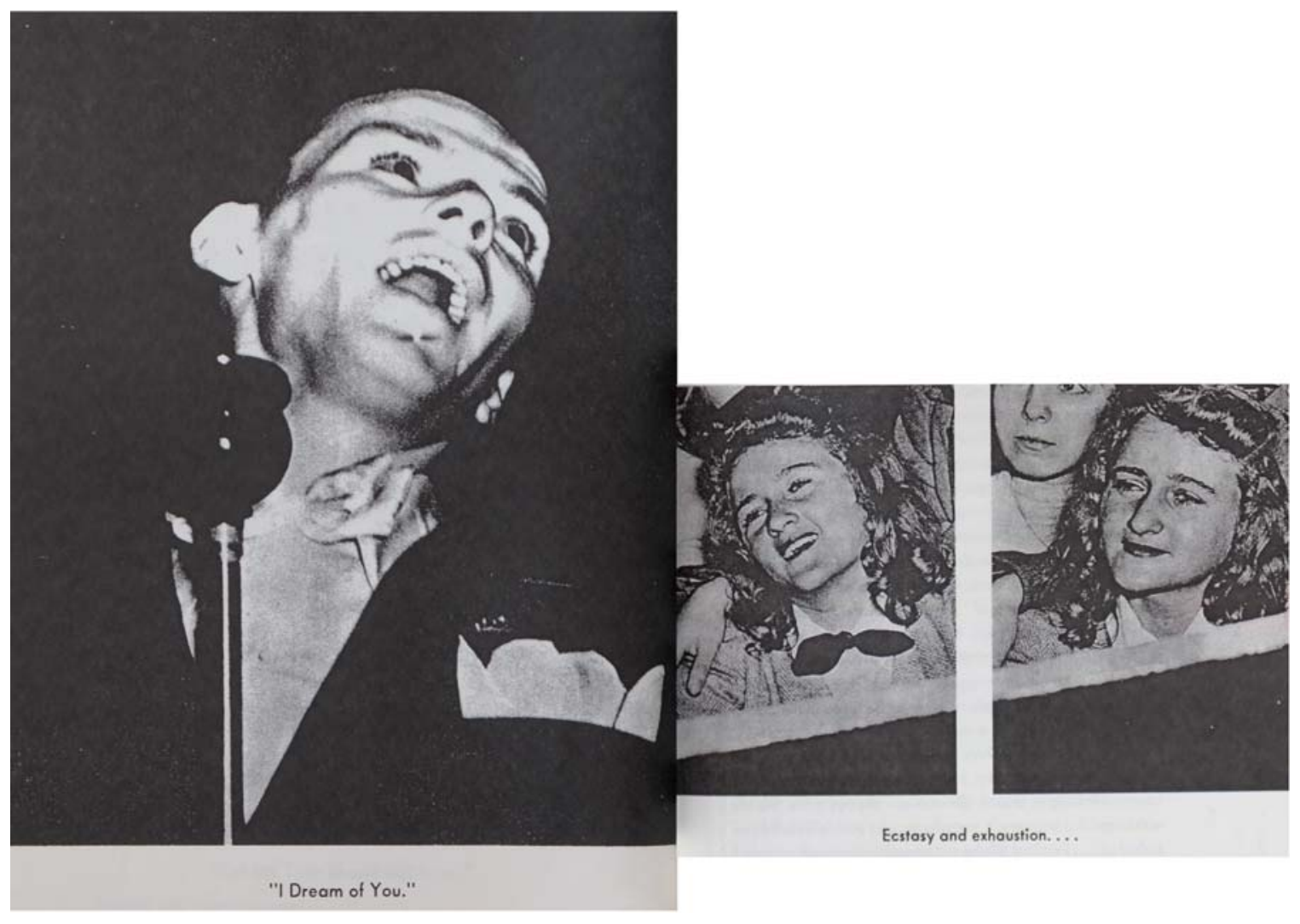

Figura 29: Weegee, quarta sequência de "Frankie", Naked City, 1945. 